A Laboratory Guide to Clinical
Hematology 


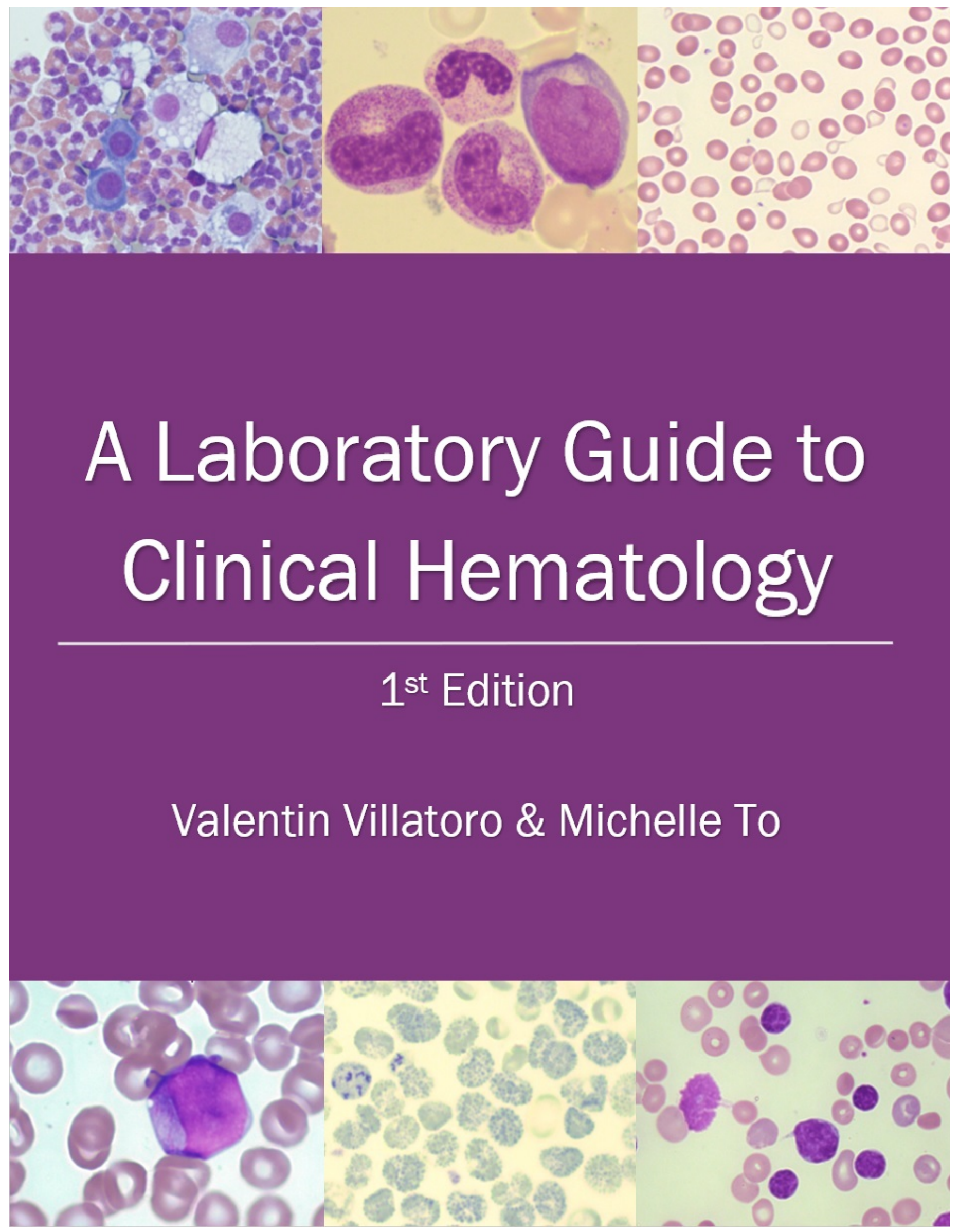


A Laboratory Guide to Clinical
Hematology 


\section{A Laboratory Guide to Clinical Hematology}

VALENTIN VILLATORO AND MICHELLE TO

EDMONTON 
A Laboratory Guide to Clinical Hematology by Michelle To is licensed under a Creative Commons Attribution-NonCommercial 4.0 International License, except where otherwise noted.

Please be aware that the content for the entirety of this eBook is subject to a creative common license: Attribution-NonCommercial 4.0 International (CC BY-NC 4.0)

\section{You are free to:}

- Share - copy and redistribute the material in any medium or format

- Adapt - remix, transform, and build upon the material

- The licensor cannot revoke these freedoms as long as you follow the license terms.

\section{Under the following terms:}

- Attribution - You must give appropriate credit, provide a link to the license, and indicate if changes were made. You may do so in any reasonable manner, but not in any way that suggests the licensor endorses you or your use.

- NonCommercial - You may not use the material for commercial purposes.

- No additional restrictions - You may not apply legal terms or technological measures that legally restrict others from doing anything the license permits. 



\section{Contents}

Authors \& Editors

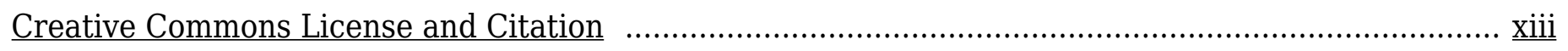

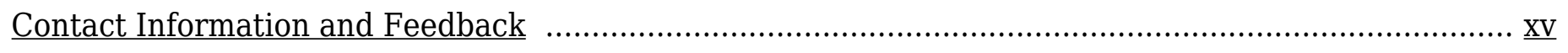

Acknowledgements and Funding …….......................................................................................

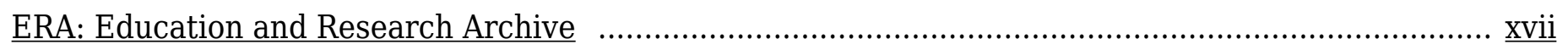

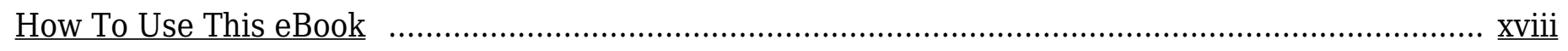

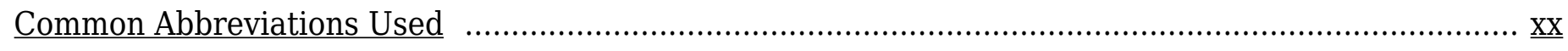

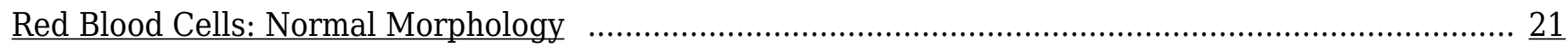

Red Blood Cell Maturation

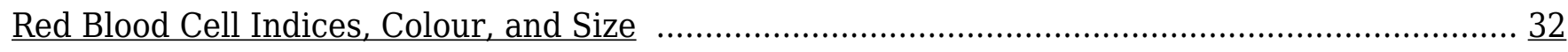

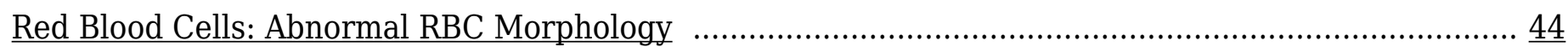

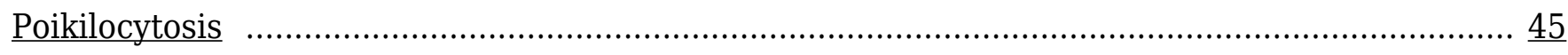

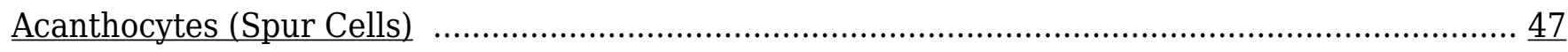

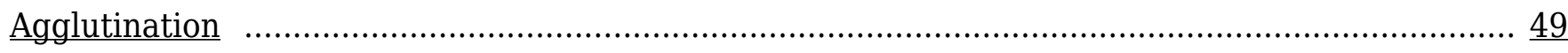

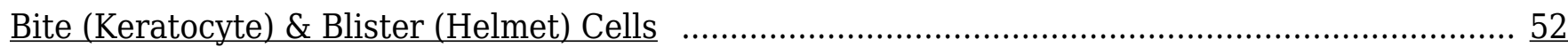

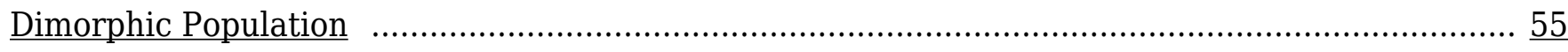

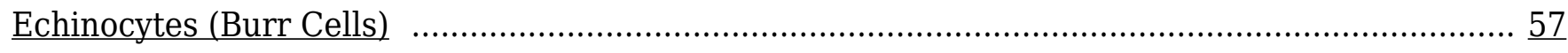

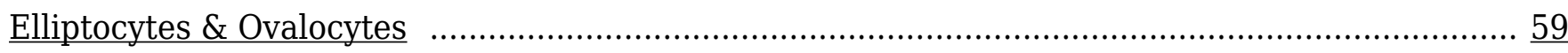

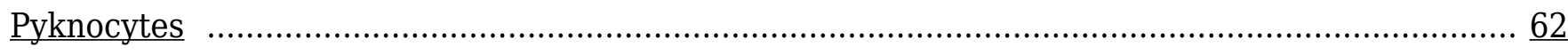

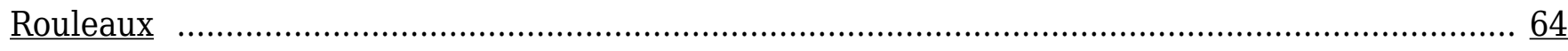

Schistocytes

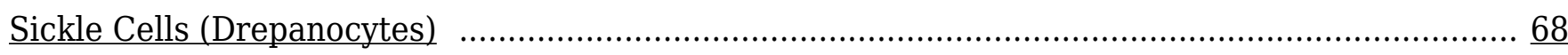

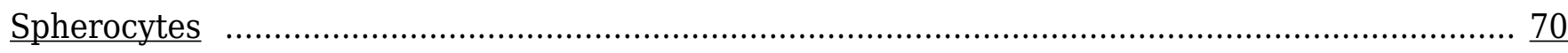

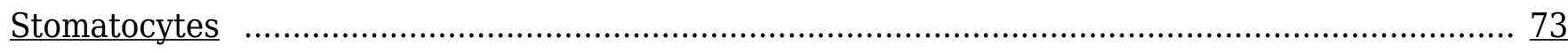

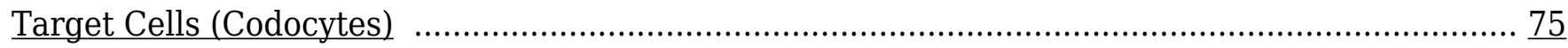

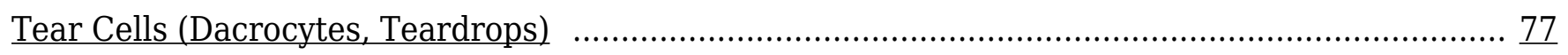

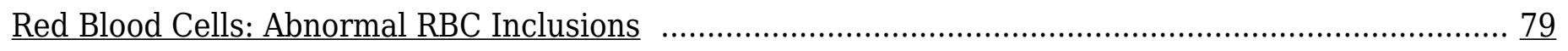

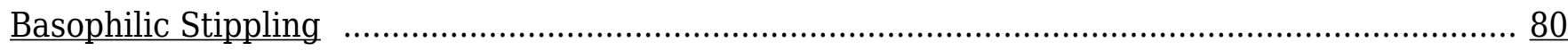

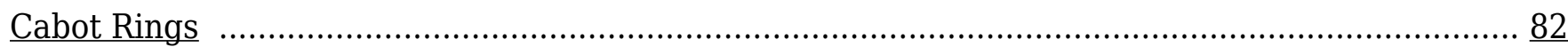

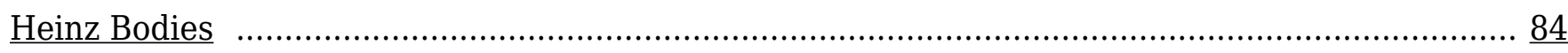

Hemoglobin $\mathrm{H}(\mathrm{Hb} \mathrm{H})$

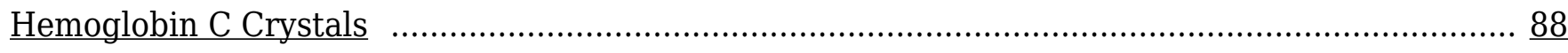

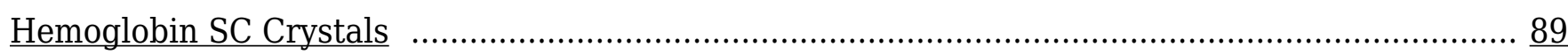

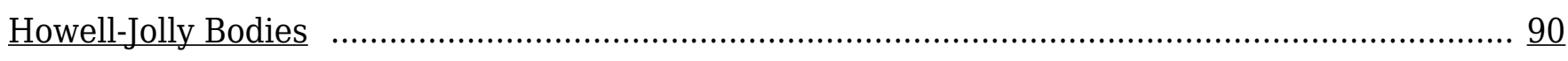

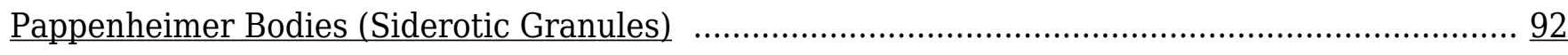

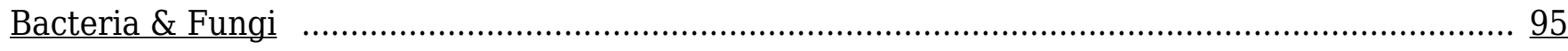

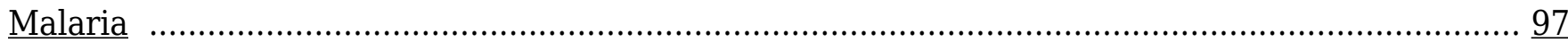

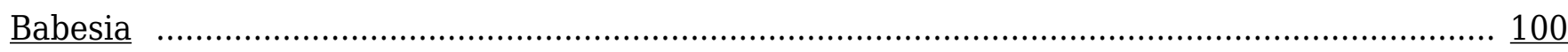




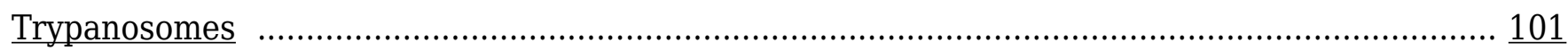

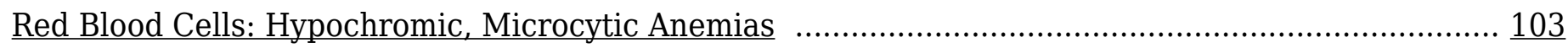

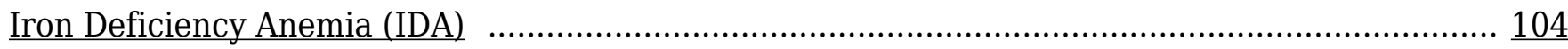

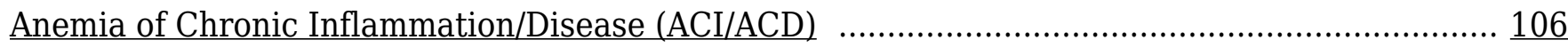

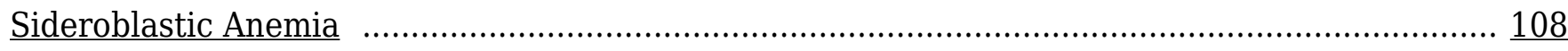

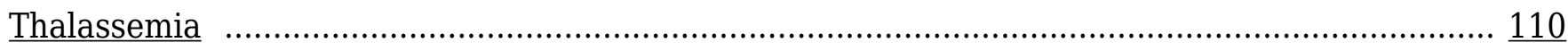

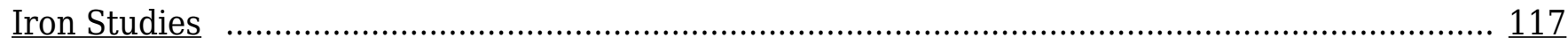

Red Blood Cells: DNA Metabolism Abnormalities \& Bone Marrow Failure ........................................ 119

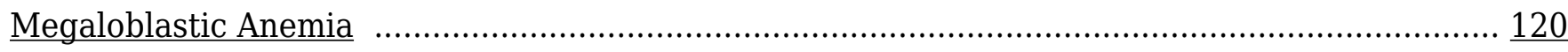

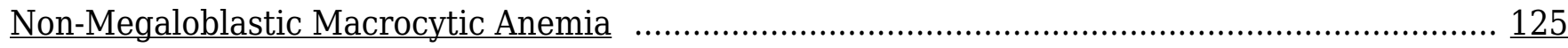

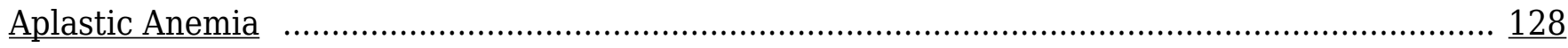

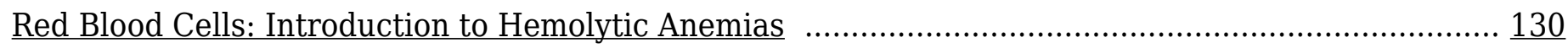

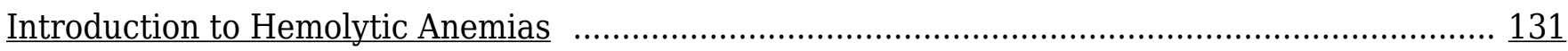

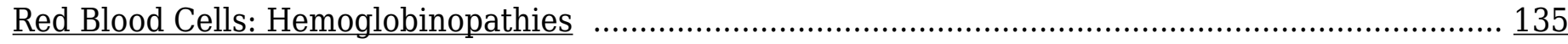

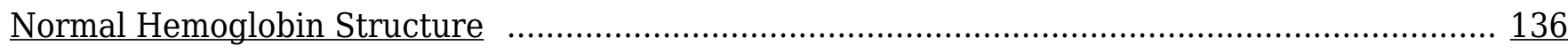

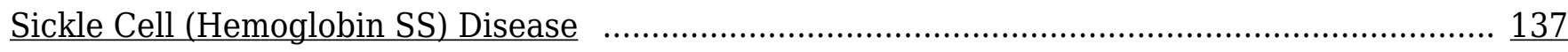

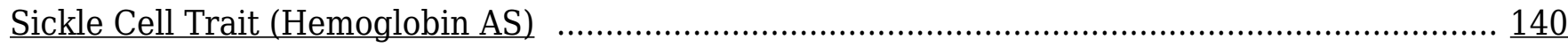

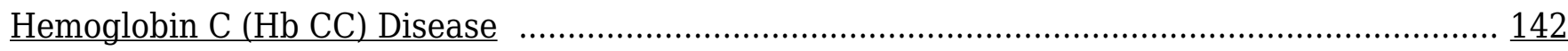

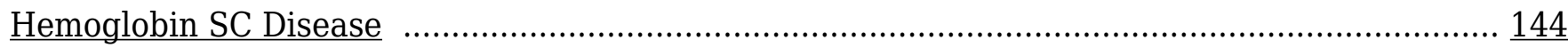

Red Blood Cells: Extrinsic Defects Causing Hemolytic Anemias …….......................................... 146

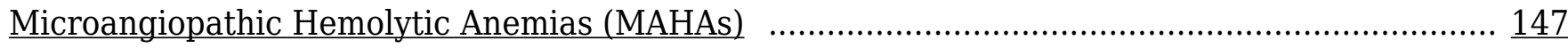

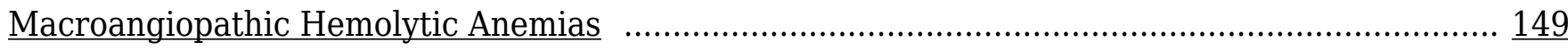

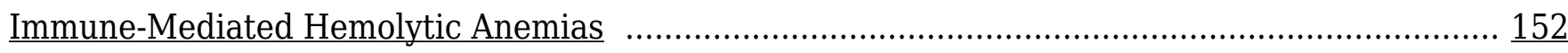

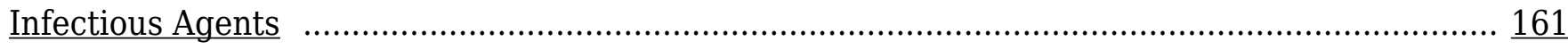

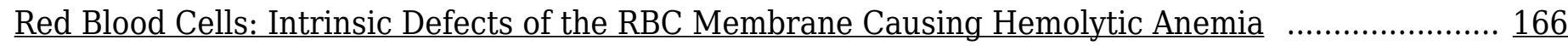

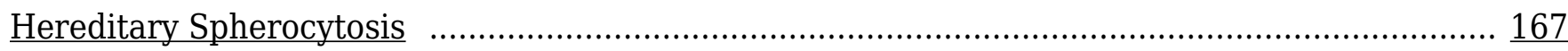

Hereditary Elliptocytosis \& Related Variants ............................................................... 170

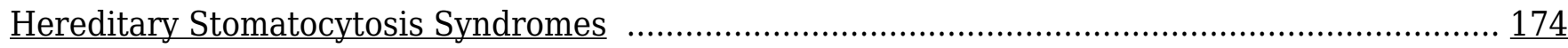

Hereditary Acanthocytosis (Abetalipoproteinemia) ……........................................................ 177

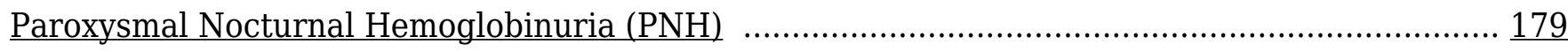

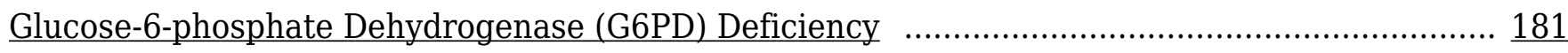

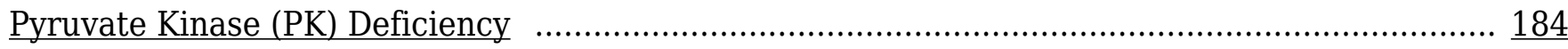

White Blood Cells and Platelets: Normal Morphology ............................................................... 187

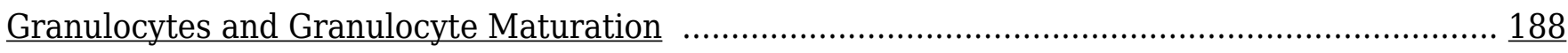

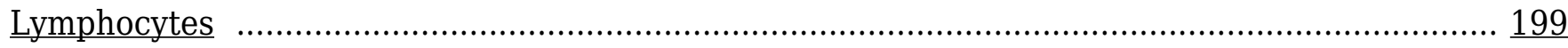

Plasma Cells

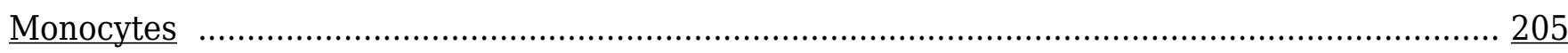

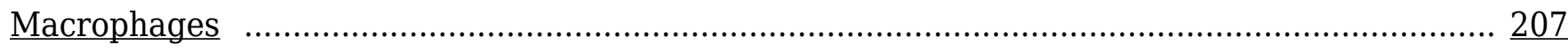

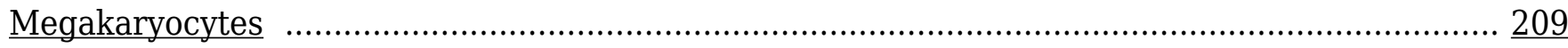

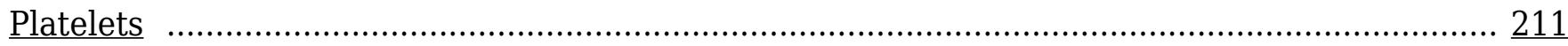

White Blood Cells: Non-Malignant Leukocyte Disorders …........................................................... 214 


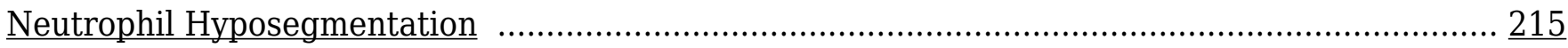

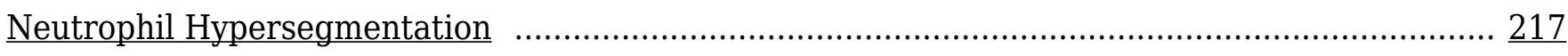

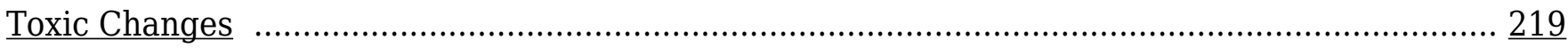

Pelger-Huet Anomaly

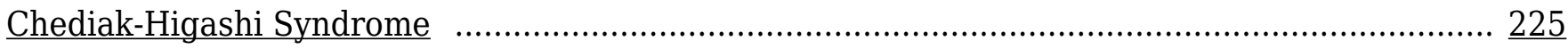

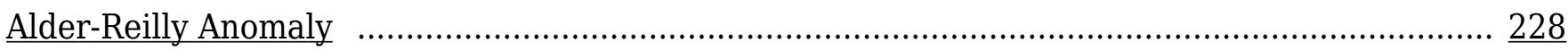

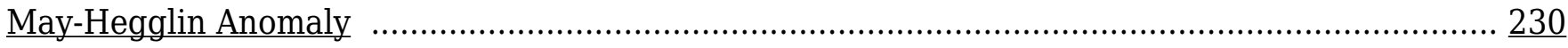

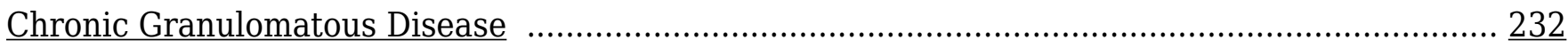

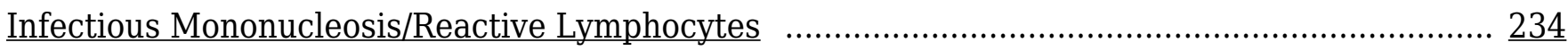

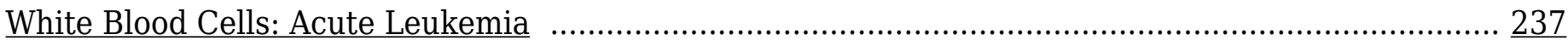

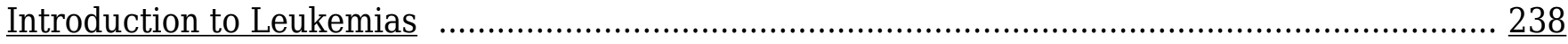

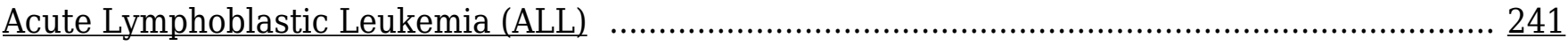

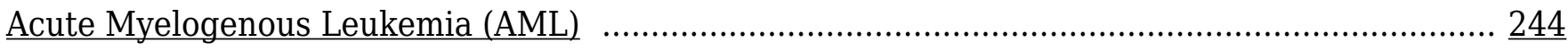

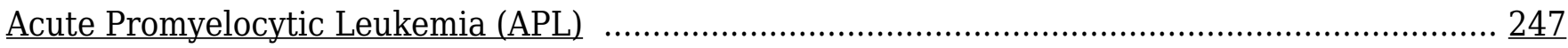

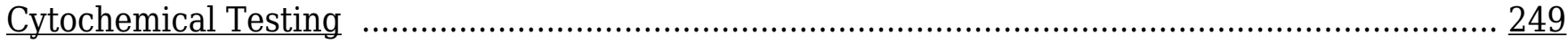

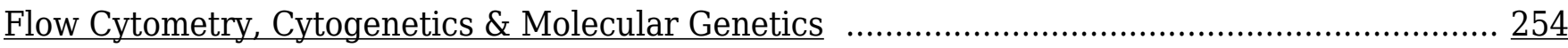

White Blood Cells: Mature Lymphoid Neoplasms ................................................................ 257

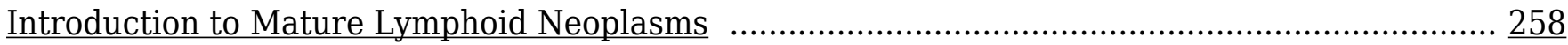

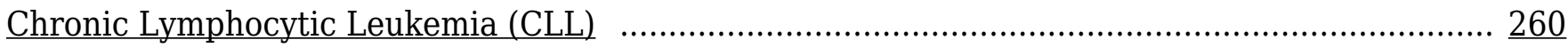

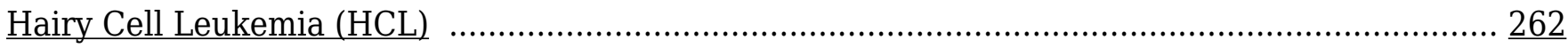

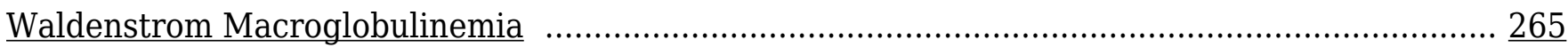

Monoclonal Gammopathy of Undetermined Significance (MGUS) …….................................... 267

Plasma Cell Myeloma (Multiple Myeloma) …………........................................................ 269

White Blood Cells: Myeloproliferative Neoplasms (MPN) ……................................................... 274

Introduction to Myeloproliferative Neoplasms (MPNs) ………........................................... 275

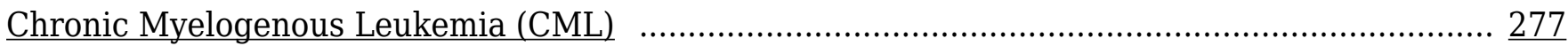

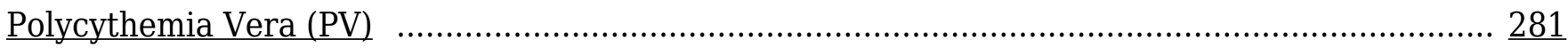

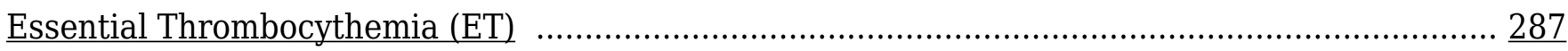

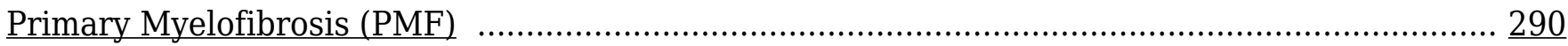

White Blood Cells: Myelodysplastic Syndromes (MDS) ……....................................................... 293

Introduction to Myelodysplastic Syndromes (MDS) ……..................................................... 294

MDS: Dyserythropoiesis, Dysmyelopoiesis \& Dysmegakaryopoiesis ........................................ 296

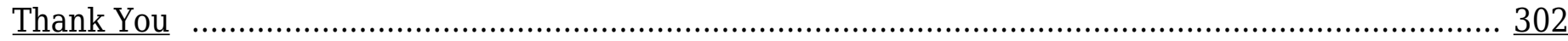





\section{Authors \& Editors}

\section{MICHELLE TO AND VALENTIN VILLATORO}

\section{Author}

\section{Michelle To}

Student

Division of Medical Laboratory Science

Department of Laboratory Medicine and Pathology

Faculty of Medicine and Dentistry, University of Alberta

\section{Author \& Editor}

Valentin (Tino) Villatoro, MEd (HSE), BSc (MLS), MLT

Assistant Professor \& Clinical Coordinator

Division of Medical Laboratory Science

Department of Laboratory Medicine and Pathology

Faculty of Medicine and Dentistry, University of Alberta 


\section{Creative Commons License and Citation}

\section{MICHELLE TO AND VALENTIN VILLATORO}

Please be aware that the content for the entirety of this eBook is subject to a creative common license: Attribution-NonCommercial 4.0 International (CC BY-NC 4.0)

\section{You are free to:}

- Share - copy and redistribute the material in any medium or format

- Adapt - remix, transform, and build upon the material

- The licensor cannot revoke these freedoms as long as you follow the license terms.

\section{Under the following terms:}

- Attribution - You must give appropriate credit, provide a link to the license, and indicate if changes were made. You may do so in any reasonable manner, but not in any way that suggests the licensor endorses you or your use.

- NonCommercial - You may not use the material for commercial purposes.

- No additional restrictions - You may not apply legal terms or technological measures that legally restrict others from doing anything the license permits.

\section{Citation for this eBook:}

To M, Villatoro V. Clinical Hematology eBook [e-book]. Edmonton (AB): University of Alberta; 2018 
[cited yyyy/MON/dd]. Available from: https://pressbooks.library.ualberta.ca/mlsci/ 


\section{Contact Information and Feedback}

\section{MICHELLE TO AND VALENTIN VILLATORO}

This is eBook will be constantly updated, edited, and reviewed as new emerging information arises. Should you have any suggestions, feedback, questions, or corrections regarding the content of this eBook, please contact Valentin (Tino) Villatoro. His contact information is listed below:

Email: valentin@ualberta.ca

Notice an issue or error? Use our Troubleshooting form to notify us:

https://docs.google.com/a/ualberta.ca/forms/d/1hT9uI8glWpQ8ljnrMeFMAkUJgl3qsEu4_HpIpjlnekY/edit ?usp=sharing

Want to give us feedback on this eBook and the resources provided? Use our Feedback form to let us know:

https://docs.google.com/a/ualberta.ca/forms/d/1dz6JhvLVk8mCi29Y3zQISeH_TMnwHQv3-ARWbQ5Vnm U/edit?usp=sharing 


\section{Acknowledgements and Funding}

\section{MICHELLE TO AND VALENTIN VILLATORO}

To Gloria Kwon, for being the foundation for the Medical Laboratory Science image collection and for your unwavering support throughout the creation of this eBook.

The initial creation of this eBook was funded and supported by an Open Education Resources Award granted by the Center for Teaching and Learning (CTL) at the University of Alberta. Special thanks to Michelle Brailey and Krysta McNutt for your assistance throughout this process.

The Authors would also like to thank the Division of Medical Laboratory Science at the University of Alberta for providing the space and support for the creation of this eBook, and Alberta Health Services and Covenant Health Medical Laboratories in the Edmonton Zone for providing microscope slides for our teaching sets. 


\section{ERA: Education and Research Archive}

\section{MICHELLE TO AND VALENTIN VILLATORO}

ERA is an open-access digital library at the University of Alberta, containing different collections of educational materials. A collection has been curated by the Medical Laboratory Science (MLS) program, which currently contains over 300 hematology images. Images used in this eBook were obtained from this collection and can be freely accessed via the DOI links provided in the image descriptions. Other hematology images not in this eBook are also available in ERA as an additional resource. The image collection can be accessed here: Medical Laboratory Science Collection

Please be aware that all images found in the ERA MLS collection are subject to a creative commons license: Attribution-NonCommercial 4.0 International (CC BY-NC 4.0)

\section{You are free to:}

- Share - copy and redistribute the material in any medium or format

- Adapt - remix, transform, and build upon the material

- The licensor cannot revoke these freedoms as long as you follow the license terms.

\section{Under the following terms:}

- Attribution - You must give appropriate credit, provide a link to the license, and indicate if changes were made. You may do so in any reasonable manner, but not in any way that suggests the licensor endorses you or your use.

- NonCommercial - You may not use the material for commercial purposes.

- No additional restrictions - You may not apply legal terms or technological measures that legally restrict others from doing anything the license permits. 


\section{How To Use This eBook}

\section{MICHELLE TO AND VALENTIN VILLATORO}

An interactive or media element has been excluded from this version of the text. You can view it online here: https://pressbooks.library.ualberta.ca/mlsci/?p=44

1. Proceed to the previous chapter

2. Proceed to the next chapter

3. Content tab allows you to navigate the entire eBook

3a. Shows the name of the collective section a group of chapters belong to

3b. Shows the name of the chapter

3c. Shows the topics discussed within a particular chapter

4. Static images related to a particular topic

4a. Shows the image itself

4b. A description is provided for each image, including a DOI link to the original image.

4c. Clicking on the image will enlarge the image a full screen. Click the back button on the browser to return to the eBook.

5. Additional images may be displayed with a slider plugin.

5a. White arrows on either the left or the right side of an image allow you to view the next or previous image. 
5b. An image description is given under the slider pluggin. Hovering your mouse over the image allows you to see which image number it corresponds to.

5c. Clicking on the DOI links will take you to the original image.

6. Clicking the arrows in the top right corner will enlarge the image to a full screen size.

6a. White arrows on either the left or the right side of an image allow you to view the next or previous image.

6b. Clicking on any of the circles on the white bar located at the bottom of the images will also allow you to navigate through the images.

6c. Clicking the "Esc" button on your keyboard will allow you to return to the eBook.

7. References for each topic are located at the bottom of the page. 


\section{Common Abbreviations Used}

MICHELLE TO AND VALENTIN VILLATORO

Below is a list of abbreviations commonly used in this eBook:

\begin{tabular}{ll}
\hline RBC & Red Blood Cell \\
WBC & White Blood Cell \\
PLT & Platelet \\
BM & Bone Marrow \\
PBS & Peripheral Blood Smear \\
CBC & Complete Blood Count \\
MCV & Mean Cell Volume \\
MCH & Mean Corpuscular Hemoglobin \\
MCHC & Mean Corpuscular Hemoglobin Concentration \\
RDW & Red Cell Distribution Width \\
Hb & Hemoglobin \\
Hct & Hematocit \\
RETIC & Reticulocyte \\
nRBC & Nucleated Red Blood Cell \\
TIBC & Total Iron Binding Capacity \\
M:E & Myeloid to Erythroid Ratio \\
N:C & Nuclear to Cytoplasmic Ratio \\
LD & Lactate Dehydrogenase \\
EVH & Extravascular Hemolysis \\
IVH & Intravascular Hemolysis \\
HPLC & High Performance Liquid Chromatography \\
DAT & Direct Antiglobulin Test \\
IAT & Indirect Antiglobulin Test \\
CD & Cluster of Differentiation/Designation \\
WHO & World Health Organization \\
\hline
\end{tabular}




\section{RED BLOOD CELLS: NORMAL MORPHOLOGY}




\section{1 \\ Red Blood Cell Maturation}

MICHELLE TO AND VALENTIN VILLATORO

\section{Pronormoblast (Rubriblast, Proerythroblast)}

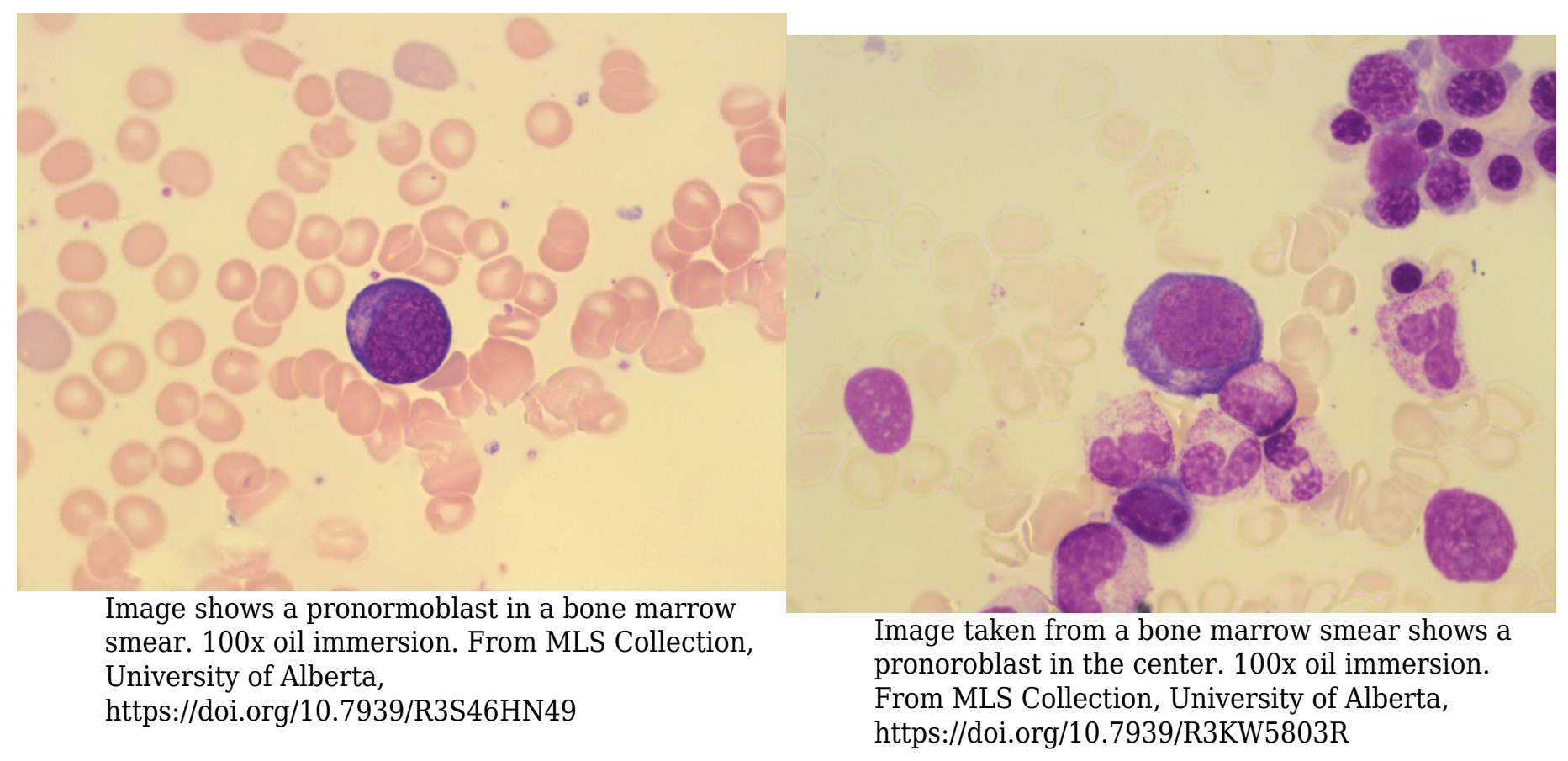

Notes: Largest of the RBC maturation series ${ }^{1}$

Nucleus-to-Cytoplasm Ratio: 8:1 (High) ${ }^{1,2}$ 


\section{Nucleus: $:^{1-3}$}

Round to oval, central

Fine, homogeneous chromatin

Reddish-blue colour under Wright stain

\section{Cytoplasm: ${ }^{1-3}$}

Small to moderate amount of cytoplasm

Dark blue cytoplasm (due to large RNA content)

Golgi may be seen (pale area next to the nucleus)

\% in Bone Marrow: $1 \%^{1-3}$

\section{Basophilic Normoblast (Prorubricyte, Basophilic Erythroblast)}

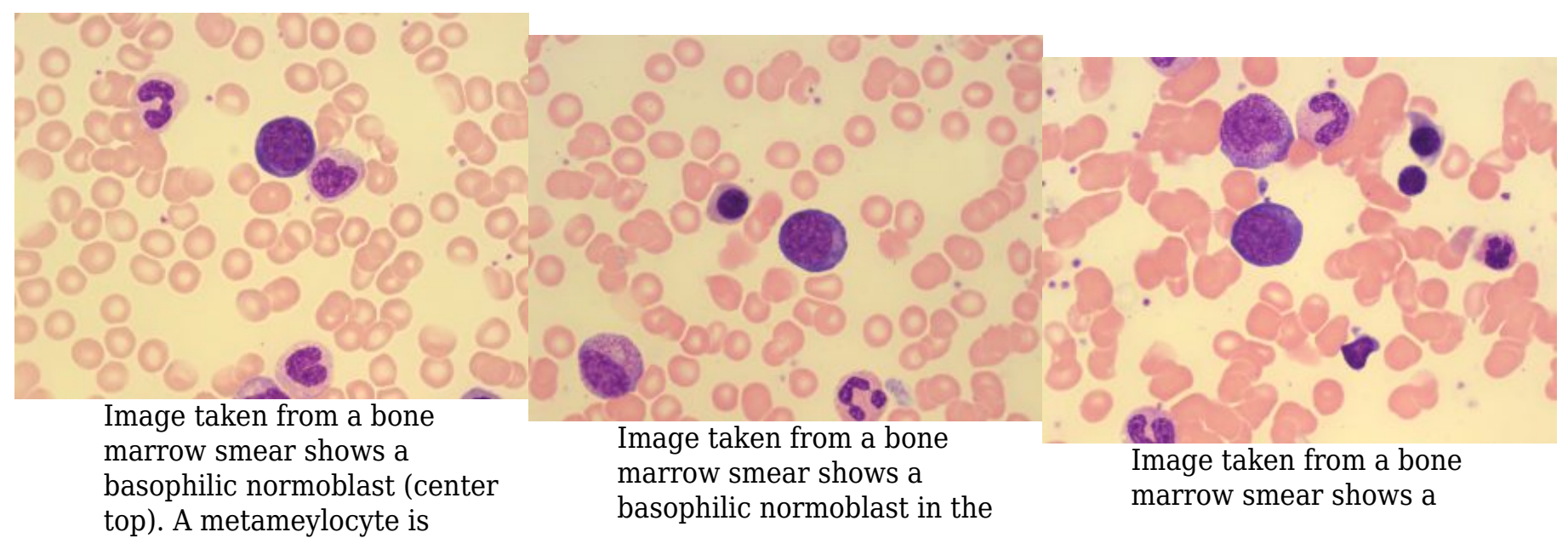


present on the right of the cell. From MLS Collection,

University of Alberta,

https://doi.org/10.7939/R3PC2T

Q99 center. 100x oil immersion. From MLS Collection,

University of Alberta,

https://doi.org/10.7939/R38C9R

K46 basophilic normoblast in the center. 100x oil immersion. From MLS Collection, University of Alberta, https://doi.org/10.7939/R3HX16 62B

Notes: Smaller than Pronormoblasts ${ }^{3}$

Nucleus-to-Cytoplasm Ratio: 6:1 ${ }^{1}$

Nucleoli: $0-1^{2}$

Nucleus: ${ }^{1-3}$

Round to slightly oval, central

Chromatin is coarser and slightly clumped

Dark violet in colour

Indistinct nuclei or not visible

\section{Cytoplasm: ${ }^{1,2}$}

Dark blue (due to large RNA content)

May see a perinuclear halo (unstained mitocondria)

May have a slight pink tinge due to the production of hemoglobin

\% in Bone Marrow: $1-5 \%^{3}$ 


\section{Polychromatic Normoblast (Rubricyte, Polychromatic Erythroblast)}

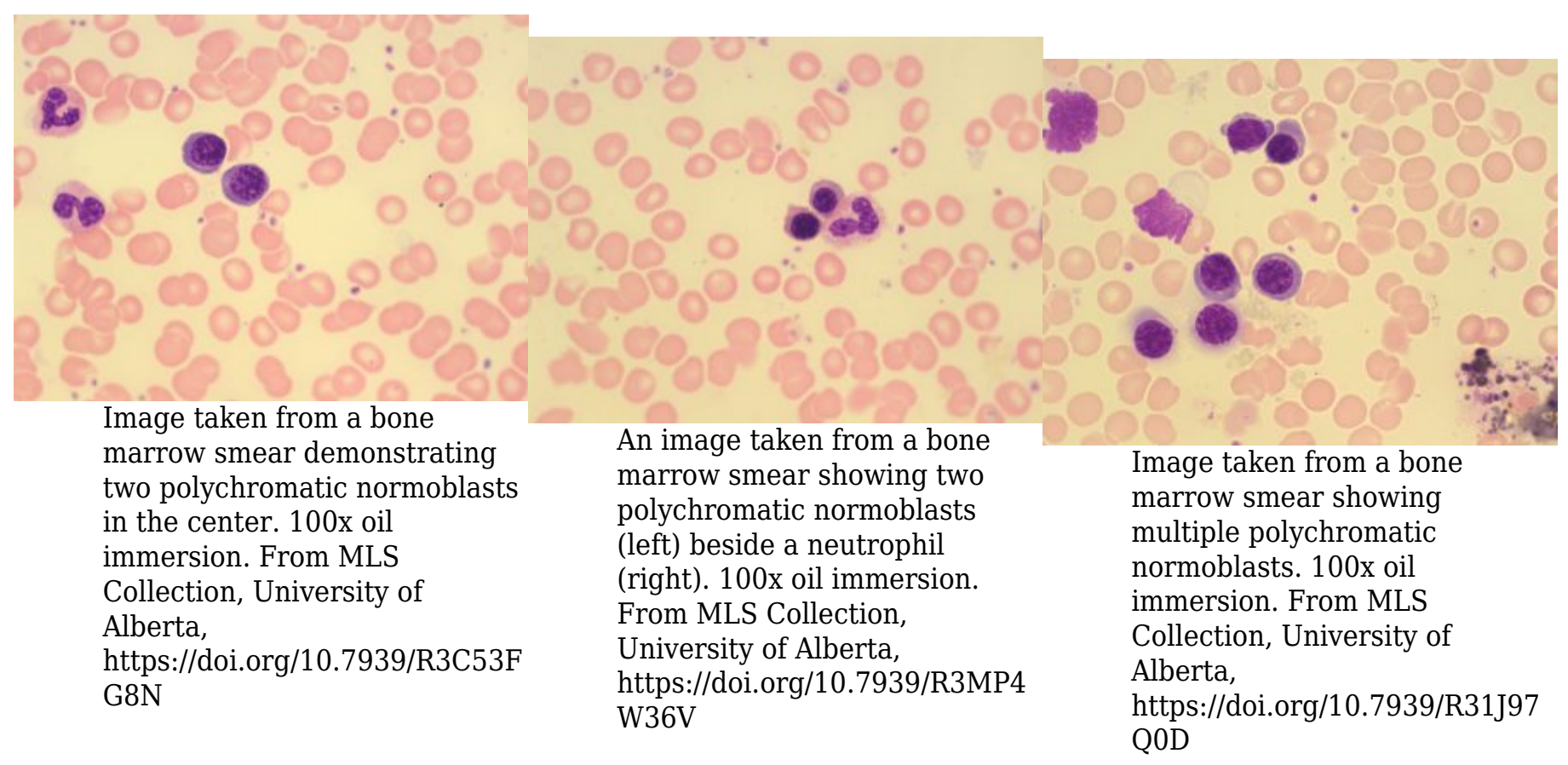

Notes: Last RBC maturation stage capable of mitosis ${ }^{1}$

Nucleus-to-Cytoplasm Ratio: $4: 1^{1-3}$

Nucleoli: None ${ }^{2}$

Nucleus: ${ }^{1-3}$ 
Round, eccentric

Chromatin is coarse, irregularly clumped

\section{Cytoplasm: ${ }^{1,2}$}

Abundant

Gray-blue to pink (due to hemoglobin production and RNA content)

\% in Bone Marrow: $5-30 \%^{3}$

\% in Peripheral Blood: Normally NOT present in the peripheral blood but some may be seen in the peripheral blood smears of newborns. ${ }^{3}$

\section{Orthochromic Normoblast (Metarubricyte, Orthochromatic Erythroblast)}

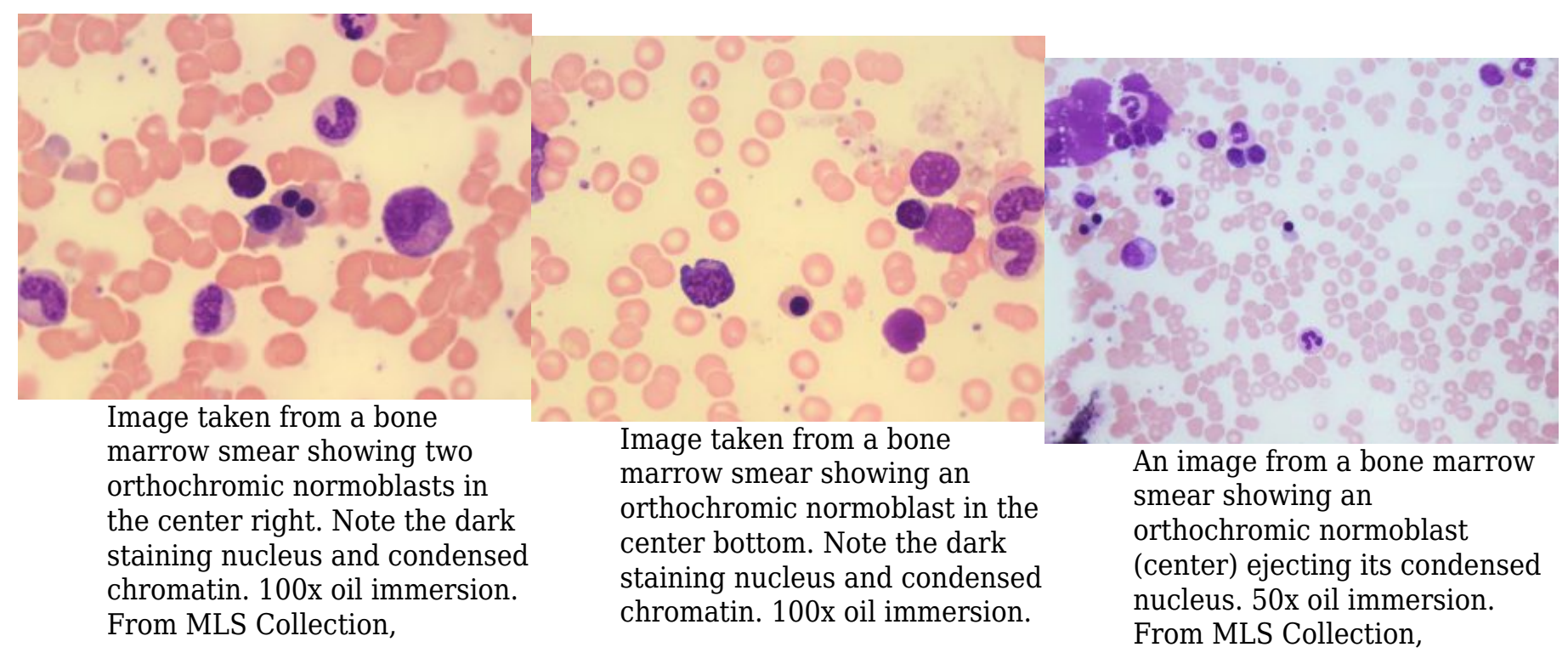


University of Alberta, https://doi.org/10.7939/R30Z71 $\mathrm{COH}$
From MLS Collection, University of Alberta, https://doi.org/10.7939/R3W669 Q5T
University of Alberta, https://doi.org/10.7939/R3599Z H3P

Notes: The smallest RBC precursor and incapable of further DNA synthesis at this stage. ${ }^{3}$

Nucleus-to-Cytoplasm Ratio: 1:1 (Low) ${ }^{3}$

Nucleoli: None ${ }^{2-3}$

Nucleus: ${ }^{1,2}$

Round, eccentric

Fully condensed chromatin with pyknotic features

Cytoplasm: ${ }^{1,2}$

Pink or salmon; May appear slightly blue due to residual RNA

\% in Bone Marrow: $5-10 \%^{2}$

\% in Peripheral Blood: Normally NOT present in the peripheral blood but some may be seen in the peripheral blood smears of newborns. ${ }^{3}$ 


\section{Reticulocyte (Polychromatic Erythrocyte, Diffusely Basophilic Erythrocyte)}
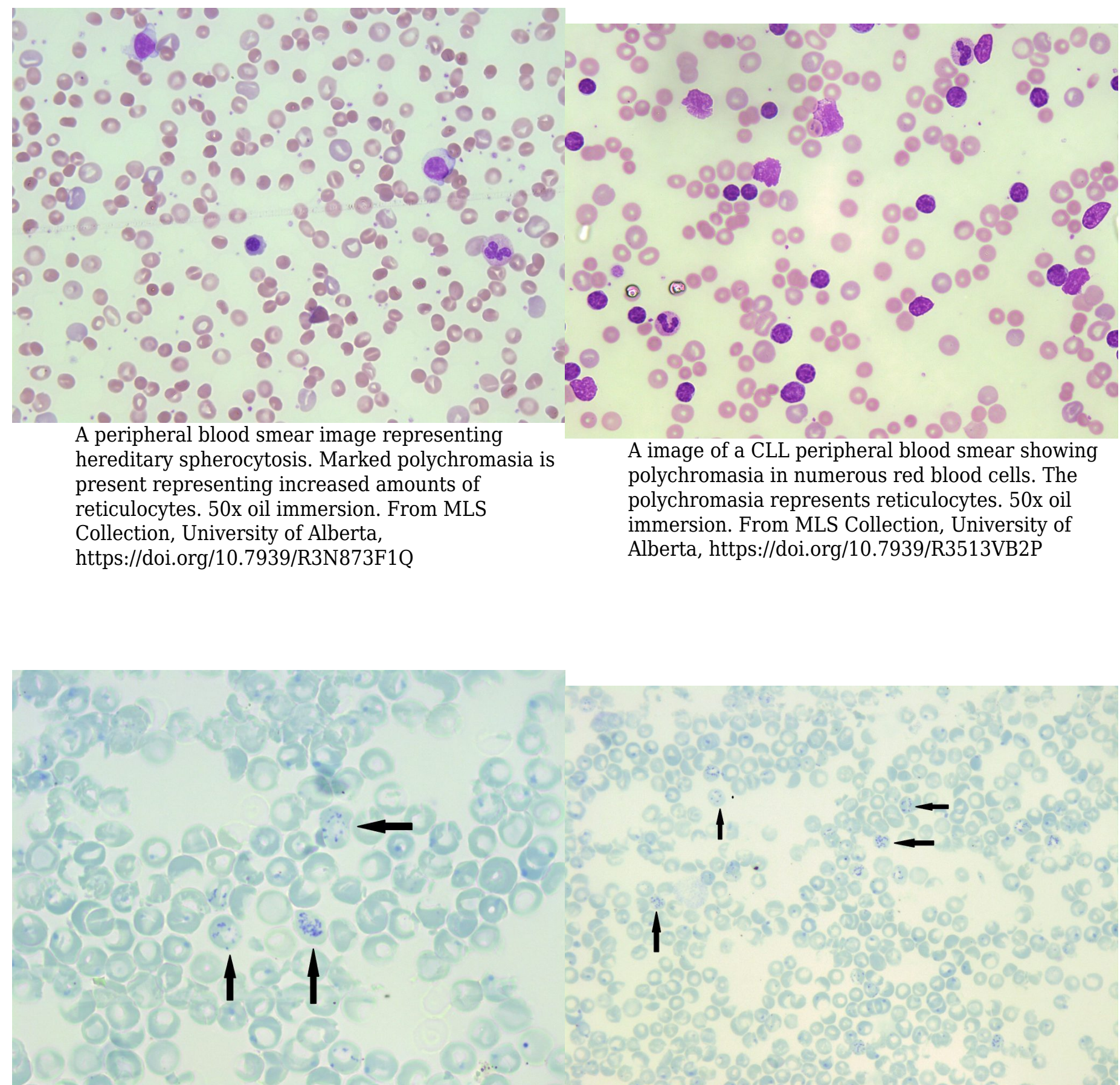

A supravital stained peripheral blood smear showing multiple reticulocytes (indicated by arrows). Note the blue stained reticulum resembling "beads on a string". 100x oil immersion. From MLS Collection, University of Alberta, https://doi.org/10.7939/R31G0J94K

An image from a peripheral blood smear stained with a supravital stain showing Heinz Body inclusions (large single blue inclusions) and reticulocytes containing dark-blue linear chains of granulation. New methylene blue. 50x oil immersion. From MLS Collection, University of Alberta, https://doi.org/10.7939/R3WP9TN91 
Notes: the nucleus has now been expelled from the cell, residual RNA gives the cell a polychromatic appearance. The use of supravital stains can help to identify and enumerate Reticulocytes by visualizing reticular inclusions (linear granulation, with a "beads on a string" appearance, see figure below). (Har ch 1 pg 13)

Nucleus-to-Cytoplasm Ratio: N/A ${ }^{2}$

Nucleoli: N/A ${ }^{2}$

Nucleus: N/A ${ }^{2}$

Cytoplasm: ${ }^{2,3}$

Light blue-purple to pink (due to residual RNA content and high hemoglobin content)

\% in Bone Marrow: $1 \%{ }^{2}$

\% in Peripheral Blood: $0.5-2 \%^{2}$

\section{Erythrocyte (Discocyte)}




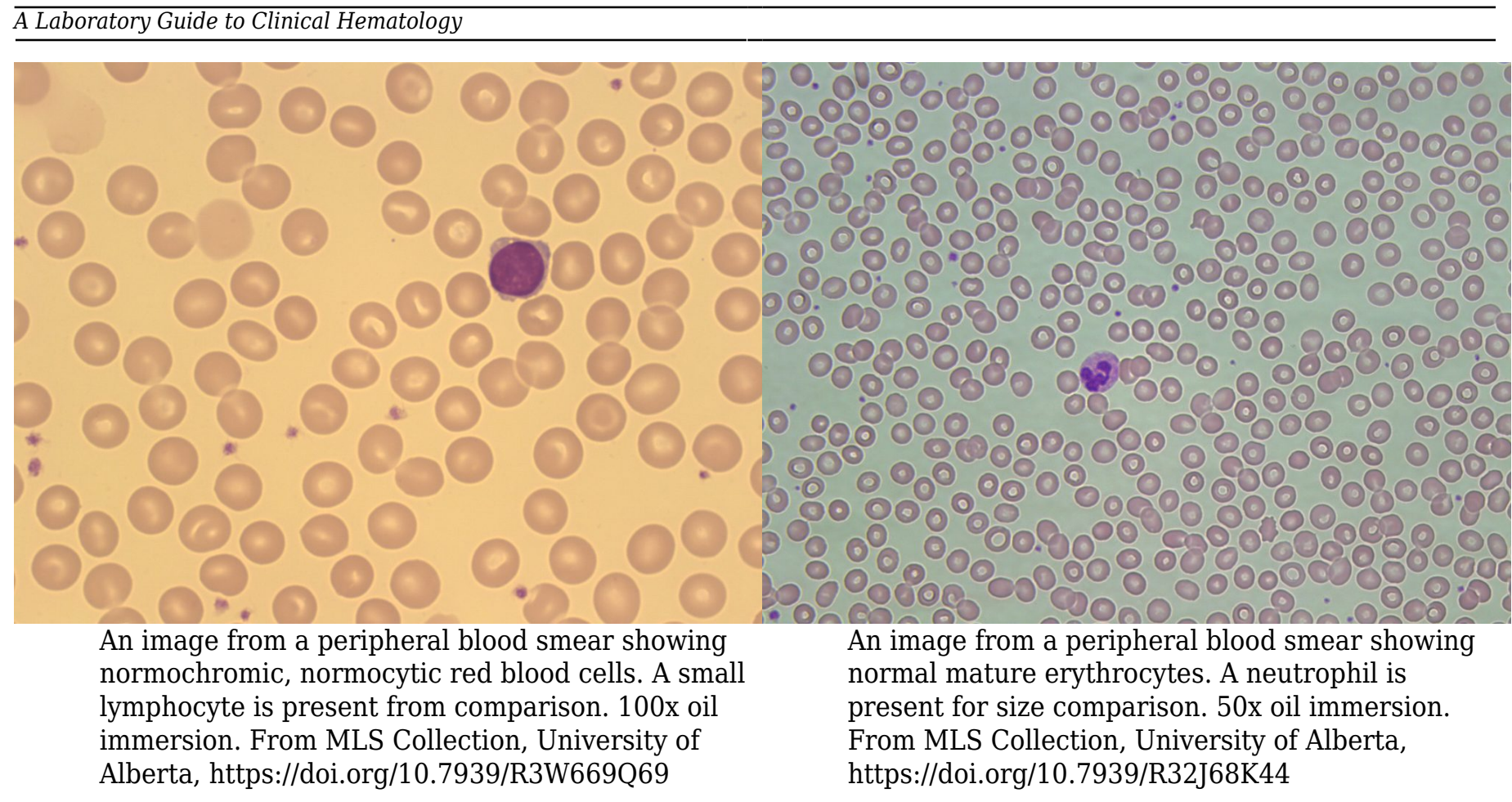

Notes: The mature red blood cell is biconcave in shape and lacks ribosomes and mitochondria; therefore, it lacks the ability to synthesize proteins such as hemoglobin and enzymes such as G6PD. ${ }^{1}$

Nucleus-to-Cytoplasm Ratio: N/A ${ }^{2}$

Nucleoli: N/A ${ }^{2}$

Nucleus: N/A ${ }^{2}$

Cytoplasm: ${ }^{2 \cdot 3}$

Pink-salmon colour with an area of central spanning one-third of the diameter. Cell should contain no inclusions. 
$\%$ in Bone Marrow: N/A ${ }^{2}$

\% in Peripheral Blood: Predominant ${ }^{2}$

\section{References:}

1. Robinson S, Hubbard J. The erythrocyte. In: Clinical laboratory hematology. 3rd ed. New Jersey: Pearson; 2015. p. 59-76.

2. Rodak BF, Carr JH. Erythrocyte maturation. In: Clinical hematology atlas. 5th ed. St. Louis, Missouri: Elsevier Inc.; 2017. p. 17-30

3. Bell A, Harmening DM, Hughes VC. Morphology of human blood and marrow cells. In: Clinical hematology and fundamentals of hemostasis. 5th ed. Philadelphia: F.A. Davis Company; 2009. p. 1-41. 


\title{
2
}

\section{Red Blood Cell Indices, Colour, and Size}

\author{
MICHELLE TO AND VALENTIN VILLATORO
}

\section{RBC Indices}

Red blood cell indices are useful parameters when investigating suspected anemia. They help provide a general idea of the clinical picture, predict the red blood cell appearance, and aid in the classification of anemia. These indices may be calculated using the red blood cell count, hematocrit, and hemoglobin values generated by automated hematology analyzers, or directly measured in the case of MCV, depending on the model of instrument being used. ${ }^{1,2}$

\section{Mean Cell Volume (MCV)}

$\operatorname{MCV}\left(\mathrm{fL}, 10 \mathrm{x}^{-15} \mathrm{~L}\right)=$

RBC Count (x10-12/L)

*Reference range: $80-100 \mathrm{fL}$

MCV is the measurement of the average red blood cell volume and is used to classify red blood cells based on size ${ }^{3,4}$

$<80 \mathrm{fL}$

80-100 fL $>100 \mathrm{fL}$
Microcytic

Normocytic

Macrocytic

Note:If the MCV is measured directly, it may be increased if there are many reticulocytes present. ${ }^{3}$ 


\section{Mean Cell Hemoglobin (MCH)}

$\mathrm{MCH}\left(\mathrm{pg}, 10 \mathrm{x}^{-12} \mathrm{~g}\right)=$ $\mathrm{Hb}(\mathrm{g} / \mathrm{L})$

RBC Count (x10-12/L)

*Reference range: $28-36 \mathrm{pg}$

$\mathrm{MCH}$ is the measurement of the average hemoglobin weight in a red blood cell. ${ }^{3}$

\section{Mean Cell Hemoglobin Concentration (MCHC)}

$\operatorname{MCHC}(g / L)=H b(g / L)$

$\operatorname{Hct}(\mathrm{L} / \mathrm{L})$

*Reference range: $310-360 \mathrm{~g} / \mathrm{L}$

$\mathrm{MCHC}$ is the measurement of the hemoglobin concentration in a population of red blood cells. This is used to denote the colour of the red blood cell population. ${ }^{3,5}$

\begin{tabular}{ll}
\hline$<310 \mathrm{~g} / \mathrm{L}$ & Hypochromic \\
$310-360 \mathrm{~g} / \mathrm{L}$ & Normochromic \\
$>360 \mathrm{~g} / \mathrm{L}$ & Check for spherocytes or errors in Hb/Hct measurement (interferences) \\
\hline
\end{tabular}

\section{Red Blood Cell Distribution Width (RDW)}

RDW is the coefficient of variation or standard deviation of the MCV. Similar to the RBC indices, it is determined by automated cell counting instruments and is used to predict the degree of red blood cell size variation, known as anisocytosis. ${ }^{2-4}$

An increase in the RDW would indicate a higher presence of anisocytosis on the peripheral blood smear. ${ }^{2-4}$ 
A decrease in the RDW is not associated with any known abnormalities. ${ }^{2-4}$

*Reference range: $11.5-14.5 \%$

*Please be aware that the reference ranges provided in this book were obtained from multiple sources and may not accurately reflect the values used in your laboratory. References ranges vary depending on institution, patient population, methodology and instrumentation. Laboratories should establish their own ranges based on these factors for their own use.

\section{Size}

As previously described, MCV is used to classify red blood cells based on their size.

\section{Normocytic RBCs}

An interactive or media element has been excluded from this version of the text. You can view it online here: https://pressbooks.library.ualberta.ca/mlsci/?p=88

Peripheral blood smears showing normochromic, normocytic red blood cells. From MLS Collection, University of Alberta.

Image 1: 100x oil immersion. https://doi.org/10.7939/R3RJ4995W

Image 2: 60x oil immersion. https://doi.org/10.7939/R35M62P2N

The MCV of normocytic RBCs fall within the normal reference ranges of 80-100 fL and the size should 
be around $7-8 \mu \mathrm{m} .{ }^{6,7}$

Size comparison:Mature red blood cells are about the size of the nucleus of a small lymphocyte. It $i$ also approximately three normal red blood cells should fit within a normal neutrophil. ${ }^{6}$

\section{Microcytic RBCs}

An interactive or media element has been excluded from this version of the text. You can view it online here: https://pressbooks.library.ualberta.ca/mlsci/?p=88

Peripheral blood smear images show numerous microcytic red blood cells. A small lymphocyte is present and can be used for a size comparison. From MLS Collection, University of Alberta.

Image 1: 50x oil immersion. https://doi.org/10.7939/R3599ZH07

Image 2: 100x oil immersion. https://doi.org/10.7939/R3WS8J199

A microcytic red blood cell measures less than $7-8 \mu \mathrm{m}$, and has an MCV that is $<80 \mathrm{fL}$. The hemoglobin concentration (MCHC) can be normal or decreased, and can help differentiate different clinical conditions or severities of anemia.

Microcytes are commonly seen with any abnormalities involving hemoglobin synthesis and thus cells often also appear hypochromic. ${ }^{3,6,7}$

Size comparison: Microcytes are smaller than the size of the nucleus of a normal small lymphocyte. If a normal neutrophil is being used for comparison, more than three microcytes can easily fit in a normal neutrophil.

\section{Associated Disease/Clinical States ${ }^{7,8}$ :}

\section{TAILS:}


Thalassemias

Anemia of chronic inflammation

Iron Deficiency Anemia

Lead poisoning

Sideroblastic Anemia

\section{Macrocytic RBCs (Round/Oval)}

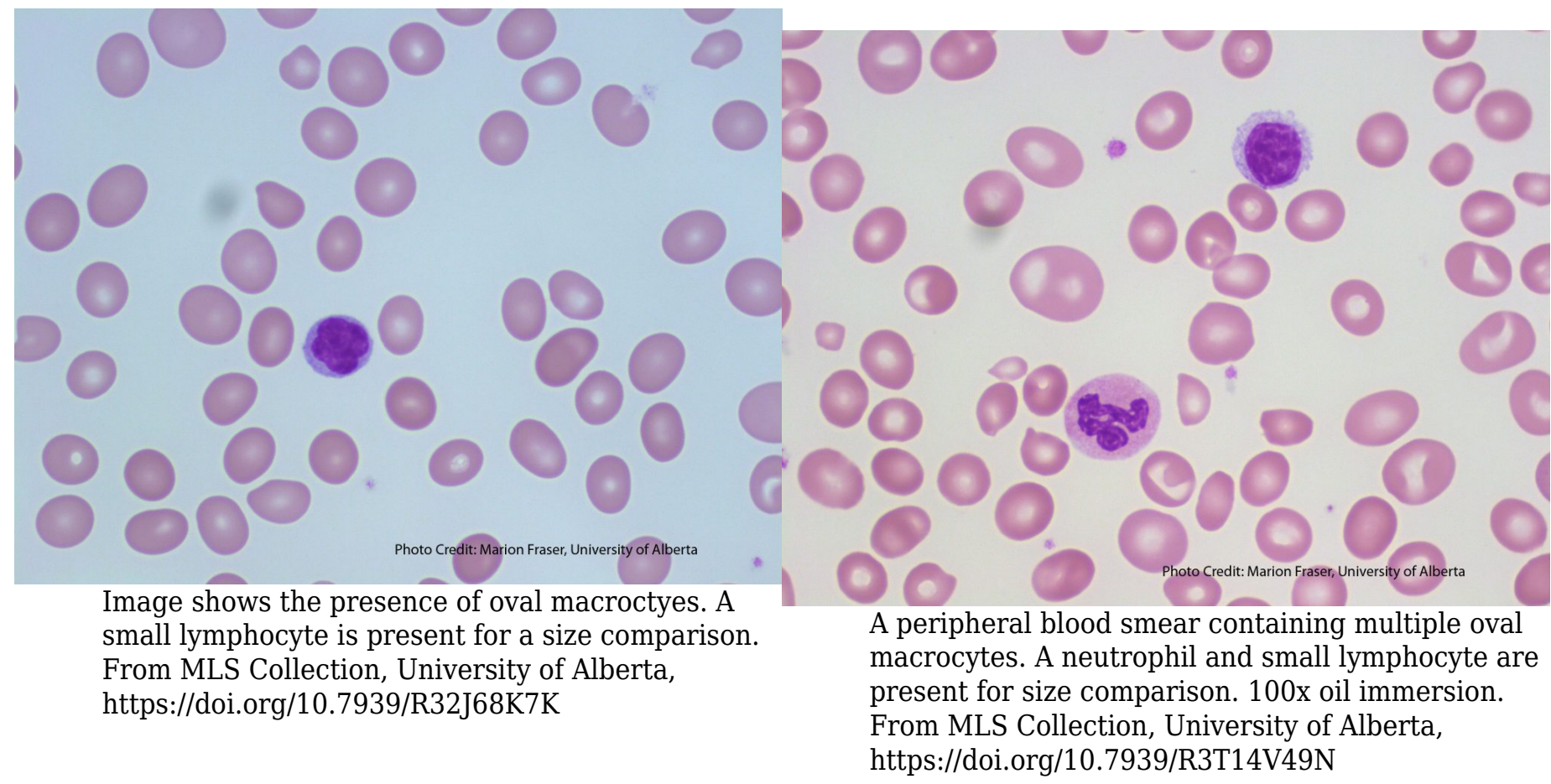




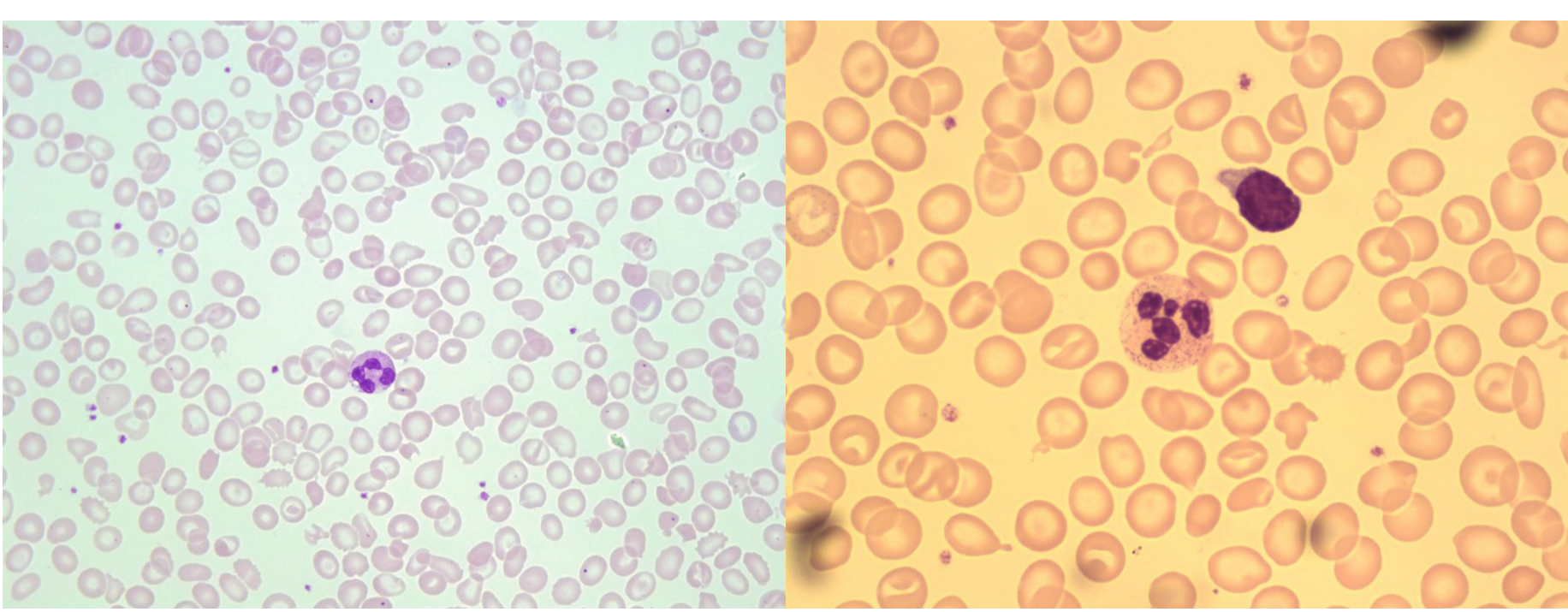

An image taken from a peripheral blood smear with round macrocytes present. A neutrophil is present

An image from a peripheral blood smear containing for a size comparison. 50x oil immersion. From MLS Collection, University of Alberta, https://doi.org/10.7939/R3W08WX8P macrocytes and poikilocytosis. 100x oil immersion. From MLS Collection, University of Alberta, https://doi.org/10.7939/R33R0Q86J

Red blood cells that are $\square 9 \mu \mathrm{m}$ in diameter and have an MCV that is $>100 \mathrm{fL}$ are considered macrocytic. Macrocytes can appear as either round or oval, which can help differentiate the underlying abnormality or disease that may be present. ${ }^{3,6,7}$

$\begin{array}{lll}\text { Shape } & \text { MCV } & \text { Associated Disease/Clinical State(s) }{ }^{7} \\ \text { Oval Macrocytes } & \text { Usually }>110 \mathrm{fL} & \text { Megaloblastic Anemia (Impaired DNA Synthesis) } \\ \text { Round Macrocytes } & 100-110 \mathrm{fL} & \begin{array}{l}\text { Non-megaloblastic Anemias (stimulated erythropoiesis) } \\ \text { Liver Disease } \\ \text { Myelodysplastic Syndromes (MDS) }\end{array}\end{array}$

Size comparison: Macrocytes are larger than normal small lymphocytes. The RBCs are large, therefore you cannot fit three within a single normal neutrophil. 


\section{Anisocytosis}

An interactive or media element has been excluded from this version of the text. You can view it online here: https://pressbooks.library.ualberta.ca/mlsci/?p=88

Images of peripheral blood smears showing anisocytosis (microcytes and normocytes are present). From MLS Collection, University of Alberta.

Image 1: 50x oil immersion. https://doi.org/10.7939/R3Q81574N

Image 2: 100x oil immersion. https://doi.org/10.7939/R3ZS2KV2F

Anisocytosis is a term used to describe variation in red blood cell size in a peripheral blood smear. The degree of anisocytosis should correlate with the Red Blood Cell Distribution Width (RDW). ${ }^{7}$

Note: If there is a wide variation of cell sizes present (microcytes and macrocytes), the MCV may appear normal as it represents the average cell volume. ${ }^{3}$

\section{Colour}

As previously discussed, MCHC can be used to determine the "colour" of the red blood cell population based on the average hemoglobin concentration. ${ }^{3}$ 


\section{Normal (Normochromic) Red Blood Cells}

An interactive or media element has been excluded from this version of the text. You can view it online here: https://pressbooks.library.ualberta.ca/mlsci/?p=88

An image from a peripheral blood smear showing normochromic, normocytic red blood cells. 50x oil immersion. From MLS Collection, University of Alberta.

Image 1: https://doi.org/10.7939/R3H12VP79

Image 2: https://doi.org/10.7939/R3MS3KH27

Red blood cells appear normal with an area of central pallor spanning approximately one-third of the diameter of the cell. $\mathrm{MCHC}$ and $\mathrm{MCH}$ are within normal ranges and cells are referred to as being "Normochromic".

MCHC: 310-360 g/L

\section{Hypochromic Cells}

An interactive or media element has been excluded from this version of the text. You can view it online here: https://pressbooks.library.ualberta.ca/mlsci/?p=88

A peripheral blood smear demonstrating hypochromic red blood cells. From MLS Collection, University of Alberta.

Image 1: 50x oil immersion. https://doi.org/10.7939/R3XS5JX94

Image 2: 100x oil immersion. https://doi.org/10.7939/R3930P92Z 
Image 3: 50x oil immersion. https://doi.org/10.7939/R3JH3DH6Q

Red blood cells have an area of central pallor that is greater than one-third of the diameter of the cell. ${ }^{6}$ The enlarged area of central pallor is due to a lack of hemoglobin content as a result of decreased hemoglobin synthesis. ${ }^{3,4}$

The MCHC is the most appropriate RBC index to use when determining hypochromia, as the MCH is not as specific. ${ }^{3,4}$

Hypochromia is often seen with microcytosis and thus have similar associated clinical and disease states. ${ }^{6}$

MCHC: $<310 \mathrm{~g} / \mathrm{L}$.

\section{Associated Disease/Clinical States ${ }^{6}$ :}

TAILS:

Thalassemias

Anemia of chronic inflammation

Iron Deficiency Anemia

Lead poisoning

Sideroblastic Anemia

\section{Polychromasia}




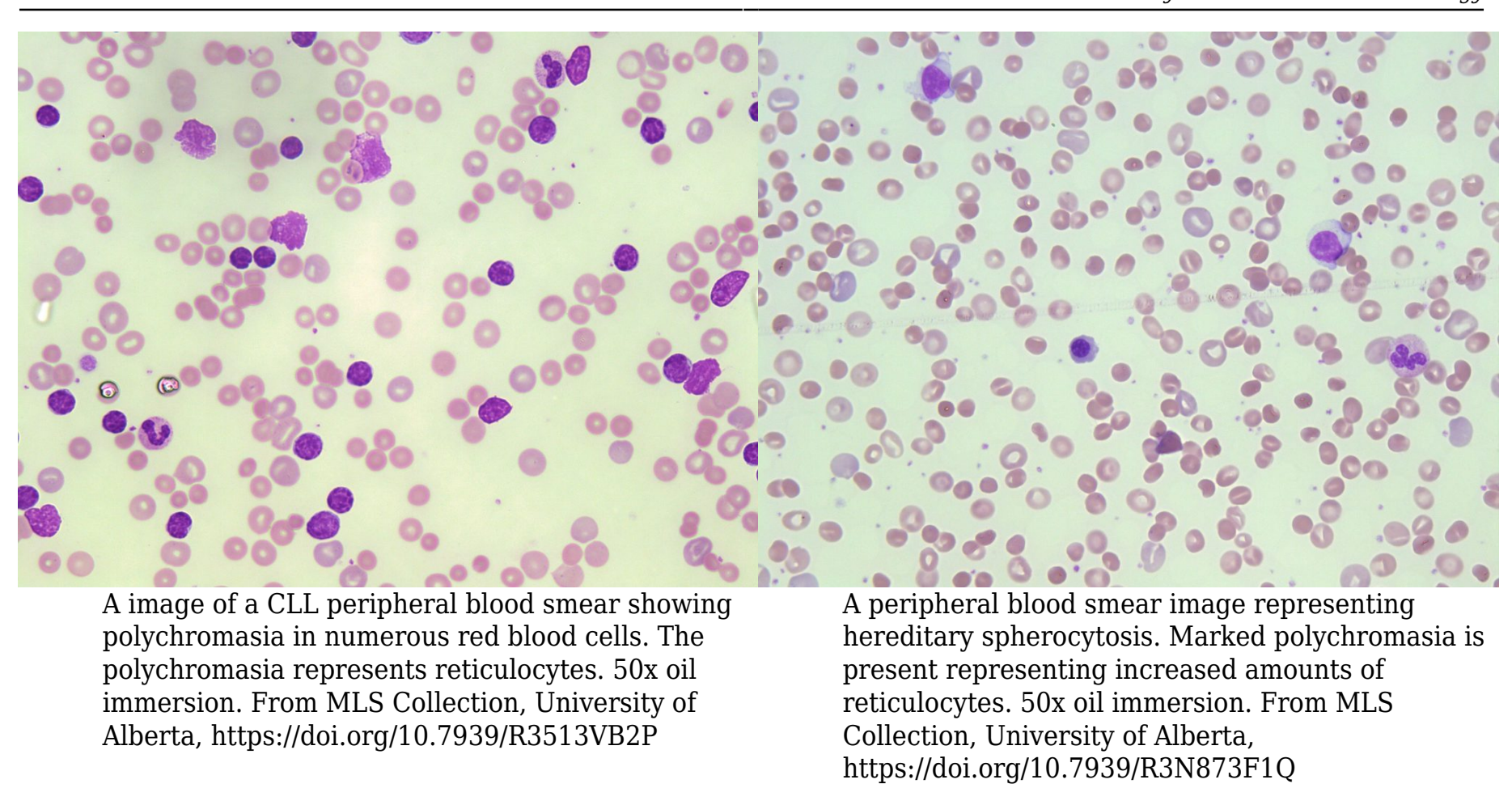

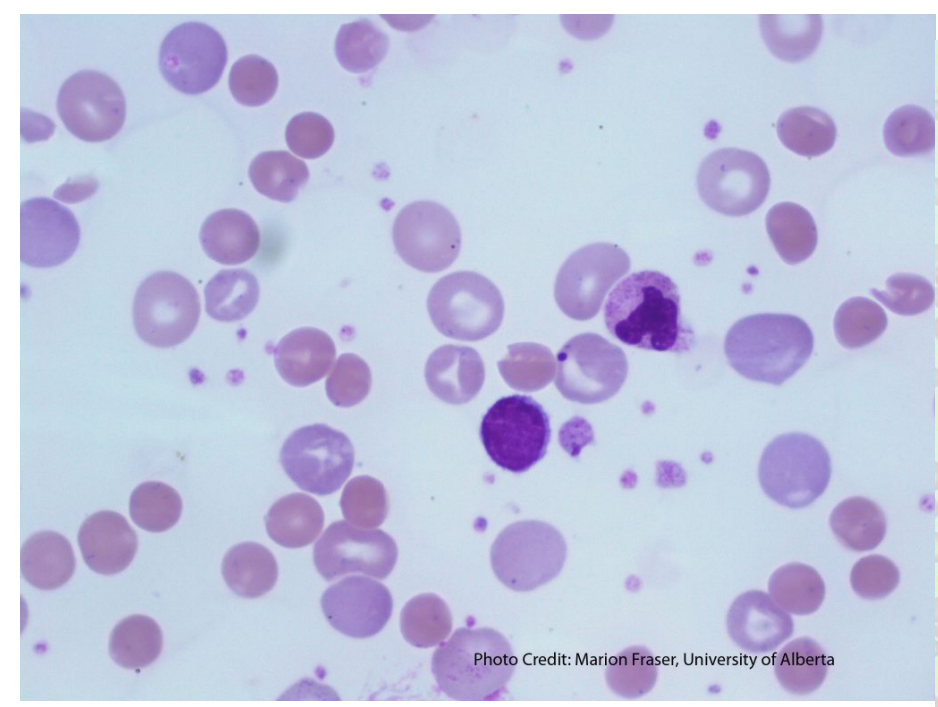

A peripheral blood smear demonstrating increased polychromasisa (Stained pale blue-purple). From MLS Collection, University of Alberta, https://doi.org/10.7939/R3DZ03H3N
A peripheral blood smear image representing hereditary spherocytosis. Marked polychromasia is present representing increased amounts of Collection, University of Alberta, https://doi.org/10.7939/R3N873F1Q
A peripheral blood smear showing a some polychromasia. 50x oil immersion. From MLS Collection, University of Alberta, https://doi.org/10.7939/R3CN6ZF3Z

The appearance of increased polychromasia on a peripheral blood smear is associated with increased red blood cell production and an increased reticulocyte count. Polychromatic cells are larger than mature red blood cells and have a blue-gray color due to the presence of residual RNA in immature red blood cells. ${ }^{3,9}$ 
Polychromatic cells are referred to as a "reticulocyte" when the cells are stained with a supravital stain such as New Methylene Blue. The supravital stain precipitates residual RNA, causing reticulocytes to have inclusions of linear chains of granulation (reticulum).,9

\section{Associated Disease/Clinical States: ${ }^{6}$}

Hemorrhage

Hemolysis

Neonates

\section{References:}

1. Glassman AB. Anemia, diagnosis and clinical considerations. In: Clinical hematology and fundamentals of hemostasis. 5th ed. Philadelphia: F.A. Davis Company; 2009. p. 82-92.

2. Hughes VC. Hematology methods. In: Clinical hematology and fundamentals of hemostasis. 5th ed. Philadelphia: F.A. Davis Company; 2009. p. 759-792.

3. Landis-Piwowar K, Landis J, Keila P. The complete blood count and peripheral blood smear evaluation. In: Clinical laboratory hematology. 3rd ed. New Jersey: Pearson; 2015. p. 154-77.

4. Maedel LB, Doig K. Examination of the peripheral blood film and correlation with the complete blood count. In: Rodak's hematology clinical applications and principles. 5th ed. St. Louis, Missouri; 2015. p. 235-52.

5. Clark KS, Hippel TC. Manual, semiautomated, and point-of-care testing in hematology. In: Rodak's hematology clinical applications and principles. 5th ed. St. Louis, Missouri: Saunders; 2015. p. 187-234).

6. Rodak BF, Carr JH. Variations in size and colour of erythrocytes. In: Clinical hematology atlas. 5th ed. St. Louis, Missouri: Elsevier Inc.; 2017. p. 89-92.

7. Jones KW. Evaluation of cell morphology and introduction to platelet and white blood cell morphology. In: Clinical hematology and fundamentals of hemostasis. 5th ed. Philadelphia: F.A. Davis Company; 2009. p. 93-116.

8. Ford J. Red blood cell morphology. Int J Lab Hematol [Internet]. 2013 Mar 9 [cited 2018 Jul 12];35(3):351-7. Available from: https://doi.org/10.1111/ijlh.12082 
9. Turgeon ML. Erythrocyte morphology and inclusions. In: Clinical hematology: theory and procedures. 4th ed. Philadelphia, PA: Lippincott Williams \& Wilkins; 1999. p. 99-111. 
II

RED BLOOD CELLS: ABNORMAL RBC MORPHOLOGY 
3

Poikilocytosis

MICHELLE TO AND VALENTIN VILLATORO

An interactive or media element has been excluded from this version of the text. You can view it online here: https://pressbooks.library.ualberta.ca/mlsci/?p=131

Peripheral blood smears demonstrating marked poikilocytosis. From MLS Collection, University of Alberta.

Image 1: 50x oil immersion. https://doi.org/10.7939/R3KD1R163

Image 2: https://doi.org/10.7939/R3RVODG2H

\section{General Peripheral Blood Smear Description:}

Poikilocytosis is a general term used to describe the collective presence of various abnormal red blood cell shapes on a peripheral blood smear. Normal red blood cell morphology is described in the previous two chapters but under certain clinical conditions, they can take on various shapes or morphologies. When certain red blood cell shapes are predominant, this may be associated with specific disease states. ${ }^{1-3}$

\section{Associated Disease/Clinical States: $:^{3-4}$}

Hemolytic anemias

Thalassemia

Myelofibrosis

Hereditary pyropoikilocytosis

Note: See the rest of the chapter for other disease states related to a specific predominant abnormal 
morphology.

\section{References:}

1. Rodak BF, Carr JH. Variations in shape and distribution of erythrocytes. In: Clinical hematology atlas. 5th ed. St. Louis, Missouri: Elsevier Inc.; 2017. p. 93-106.

2. Jones KW. Evaluation of cell morphology and introduction to platelet and white blood cell morphology. In: Clinical hematology and fundamentals of hemostasis. 5th ed. Philadelphia: F.A. Davis Company; 2009. p. 93-116.

3. Turgeon ML. Erythrocyte morphology and inclusions. In: Clinical hematology: theory and procedures. 4th ed. Philadelphia, PA: Lippincott Williams \& Wilkins; 1999. p. 99-111.

4. Coetzer TL, Zail S. Introduction to hemolytic anemias: intracorpusculardefects: I. hereditary defects of the red cell membrane. In: Clinical hematology and fundamentals of hemostasis. 5th ed. Philadelphia: F.A. Davis Company; 2009. p. 176-95. 


\section{4 \\ Acanthocytes (Spur Cells)}

\section{MICHELLE TO AND VALENTIN VILLATORO}

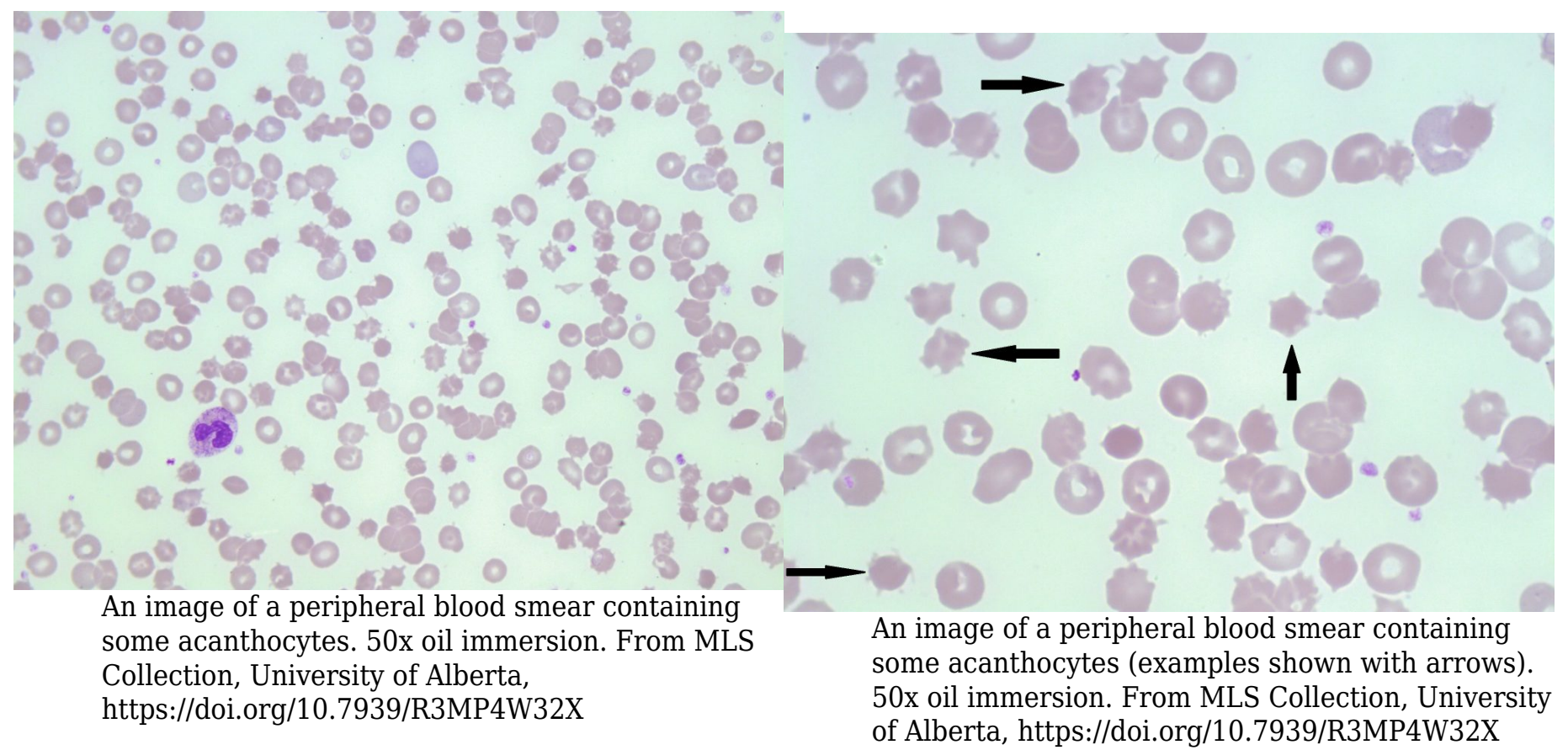

\section{Cell Description:}

Red blood cells appear small and dense, lacking an area of central pallor with multiple spiky projections (spicules) of varying lengths protruding from the membrane. Projections are irregularly distributed around the cell membrane. ${ }^{1-3}$

\section{Cell Formation:}

Acanthocyte formation occurs as a result of either hereditary or acquired membrane defects. Defects that cause an imbalance between the membrane cholesterol and lipid content affect the RBC's ability to deform resulting in more rigid plasma membrane. Red blood cells are then remodelled in circulation, resulting in an acanthocyte. . $^{1,3,4}$ 


\section{Associated Disease/Clinical States: ${ }^{1-5}$}

Abetalipoproteinemia (Inherited)

Lecithin-cholesterol acyltransferase (LCAT) Deficiency

Liver Disease

Post-splenectomy

Pyruvate Kinase (PK) Deficiency

\section{References:}

1. Cochran-Black D. Hemolytic anemia: membrane defects. In: Clinical laboratory hematology. 3rd ed. New Jersey: Pearson; 2015. p. 317-33.

2. Manchanda N. Anemias: red blood morphology and approach to diagnosis. In: Rodak's hematology clinical applications and principles. 5th ed. St. Louis, Missouri: Saunders; 2015. p. 284-96.

3. Turgeon ML. Normal erythrocyte lifecycle and physiology. In: Clinical hematology: theory and procedures. 4th ed. Philadelphia, PA: Lippincott Williams \& Wilkins; 1999. p. 71-98

4. Harmening D. The red blood cell: structure and function. In: Clinical hematology and fundamentals of hemostasis. 5th ed. Philadelphia: F.A. Davis Company; 2009. p. 759-792.

5. Rodak BF, Carr JH. Variations in shape and distribution of erythrocytes. In: Clinical hematology atlas. 5th ed. St. Louis, Missouri: Elsevier Inc.; 2017. p. 93-106. 


\section{5}

\section{Agglutination}

\section{MICHELLE TO AND VALENTIN VILLATORO}

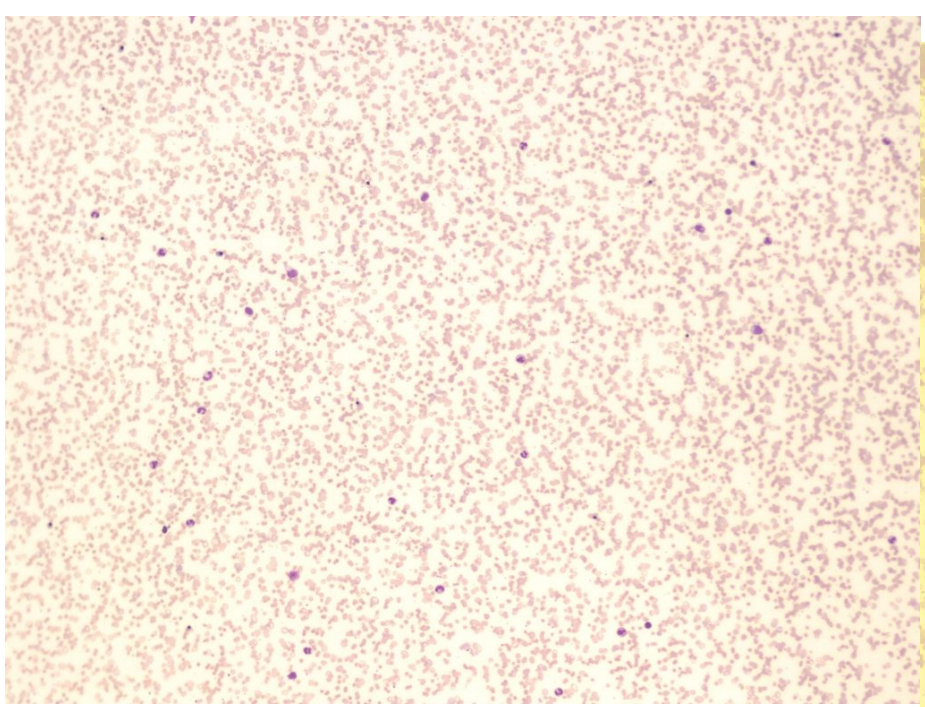

A peripheral blood smear demonstrating agglutination of red blood cells. 10x magnification. From MLS Collection, University of Alberta, https://doi.org/10.7939/R3C824V90
A peripheral blood smear demonstrating severe agglutination of red blood cells. 10x magnification. From MLS Collection, University of Alberta, https://doi.org/10.7939/R34J0BC72

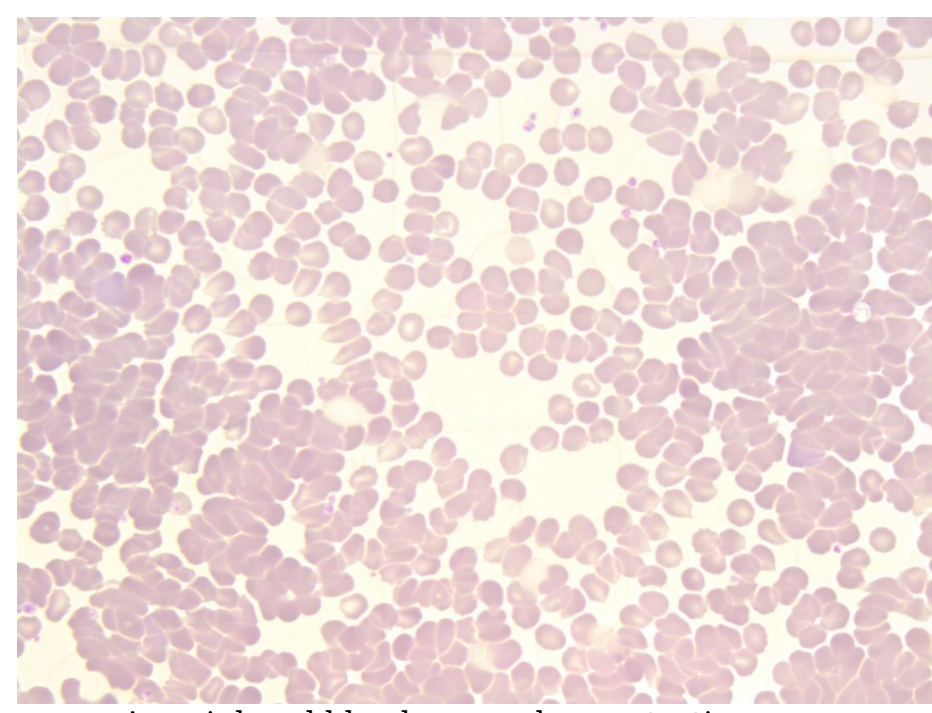

A peripheral blood smear demonstrating autoagglutination of red blood cells. 50x oil immersion. From MLS Collection, University of Alberta, https://doi.org/10.7939/R3599ZH26

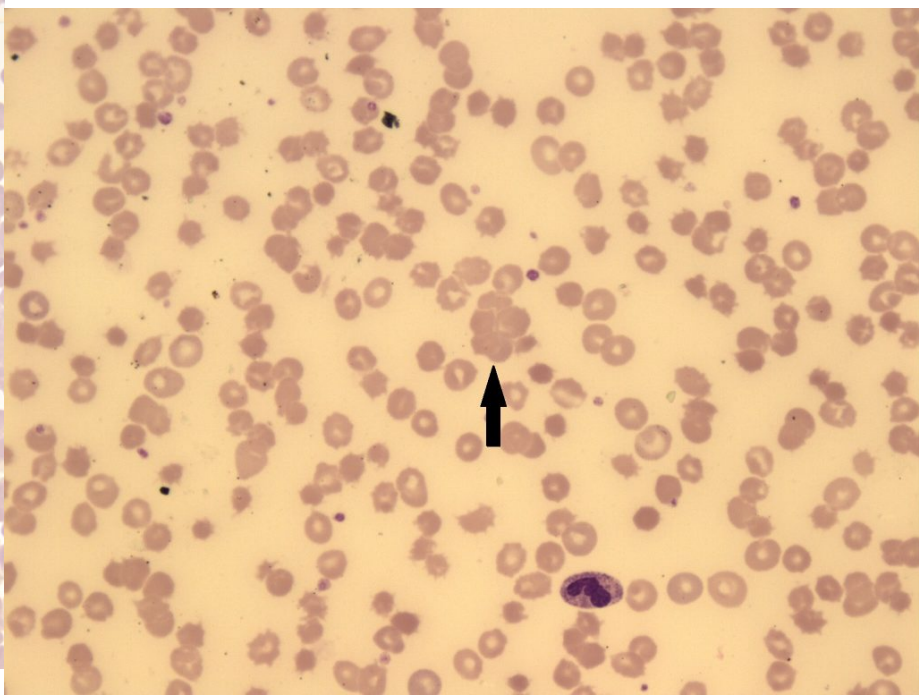

An image from a peripheral blood smear showing agglutination of red blood cells. The arrow points to a cluster of red blood cells. 50x magnification. From MLS Collection, University of Alberta, 


\section{Cell Description:}

This alteration of RBC distribution presents as irregular and random grape-like clusters or clumps. Agglutination is differentiated from Rouleaux by the lack of linear chains or "coin staking". ${ }^{1-4}$

The outlines of individual cells may not be evident.

\section{Cell Formation:}

Agglutination is caused by the formation of antibody-antigen complexes and occurs at room temperatures. Auto-agglutination is produced as a result of a complex formed between the patient's own RBC antigens and antibodies, mediated by cold-reacting antibodies. Agglutination can be reversed when the blood sample is warmed to $37^{\circ} \mathrm{C} .{ }^{1,2,5}$

\section{Associated Disease/Clinical States: ${ }^{2-4}$}

Cold Hemagglutinin Disease

Paroxysmal Cold Hemoglobinuria

Cold Autoimmune Hemolytic Anemia

Note: Formation is NOT reversed with the addition of saline. ${ }^{5}$

\section{References:}

1. Hemolytic anemia: membrane defects. In: Clinical laboratory hematology. 3rd ed. New Jersey: Pearson; 2015. p. 317-33. 
2. Jones KW. Evaluation of cell morphology and introduction to platelet and white blood cell morphology. In: Clinical hematology and fundamentals of hemostasis. 5th ed. Philadelphia: F.A. Davis Company; 2009. p. 93-116.

3. Ford J. Red blood cell morphology. Int J Lab Hematol [Internet]. 2013 Mar 9 [cited 2018 Jul 12];35(3):351-7. Available from: https://doi.org/10.1111/ijlh.12082

4. Turgeon ML. Normal erythrocyte lifecycle and physiology. In: Clinical hematology: theory and procedures. 4th ed. Philadelphia, PA: Lippincott Williams \& Wilkins; 1999. p. 71-98.

5. Rodak BF, Carr JH. Variations in shape and distribution of erythrocytes. In: Clinical hematology atlas. 5th ed. St. Louis, Missouri: Elsevier Inc.; 2017. p. 93-106. 
6

\section{Bite (Keratocyte) \& Blister (Helmet) Cells}

\section{MICHELLE TO AND VALENTIN VILLATORO}

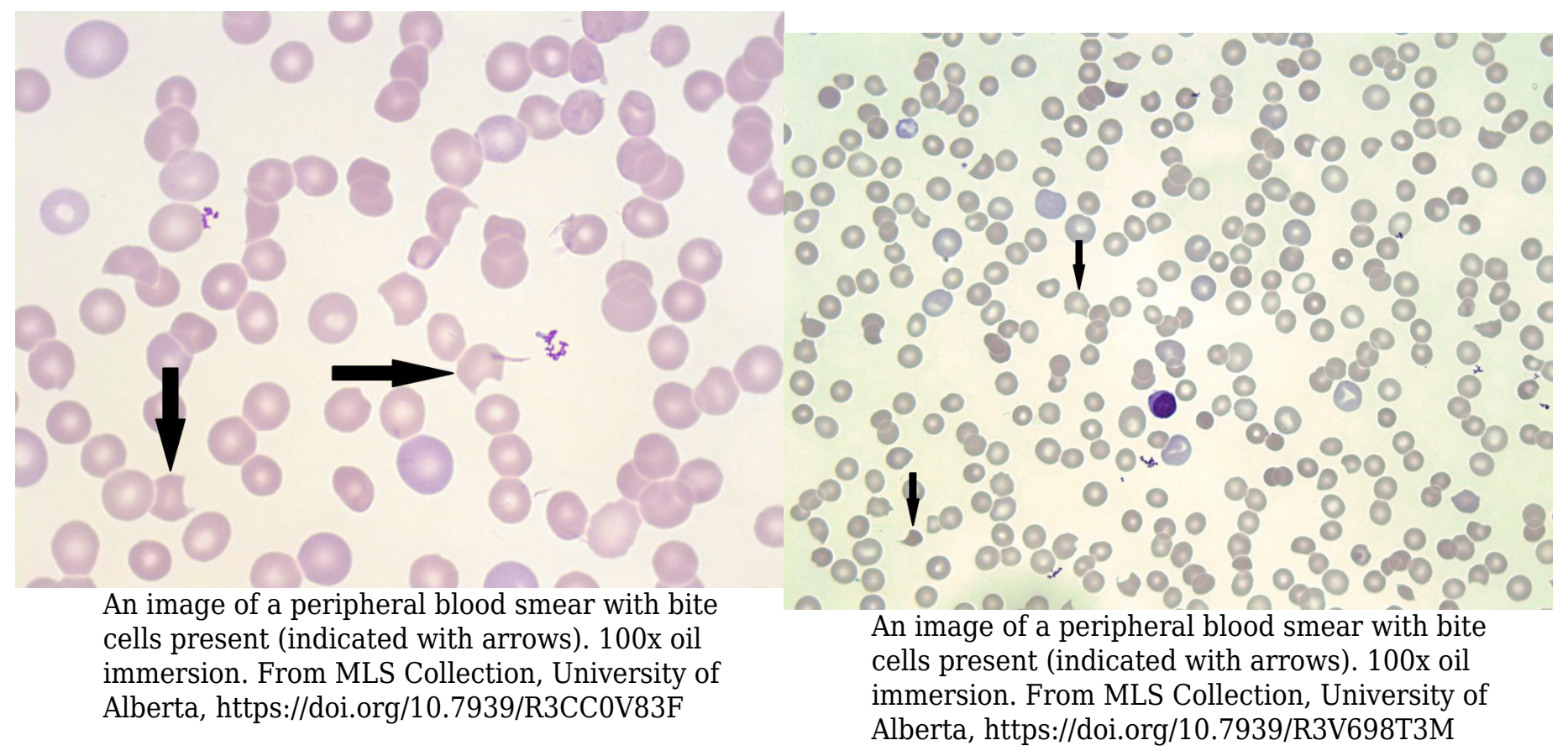

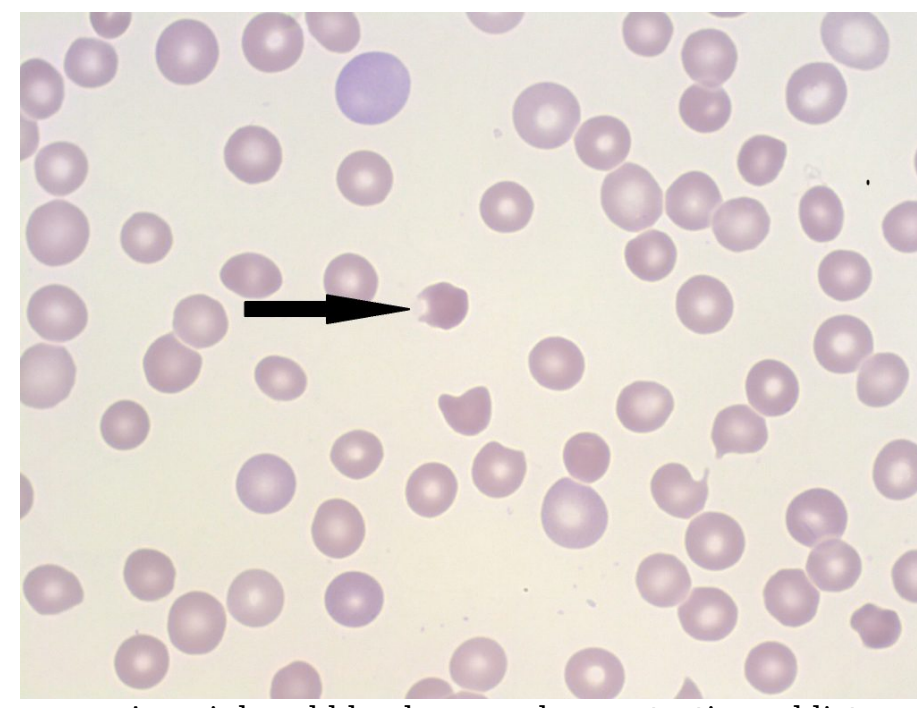

A peripheral blood smear demonstrating a blister

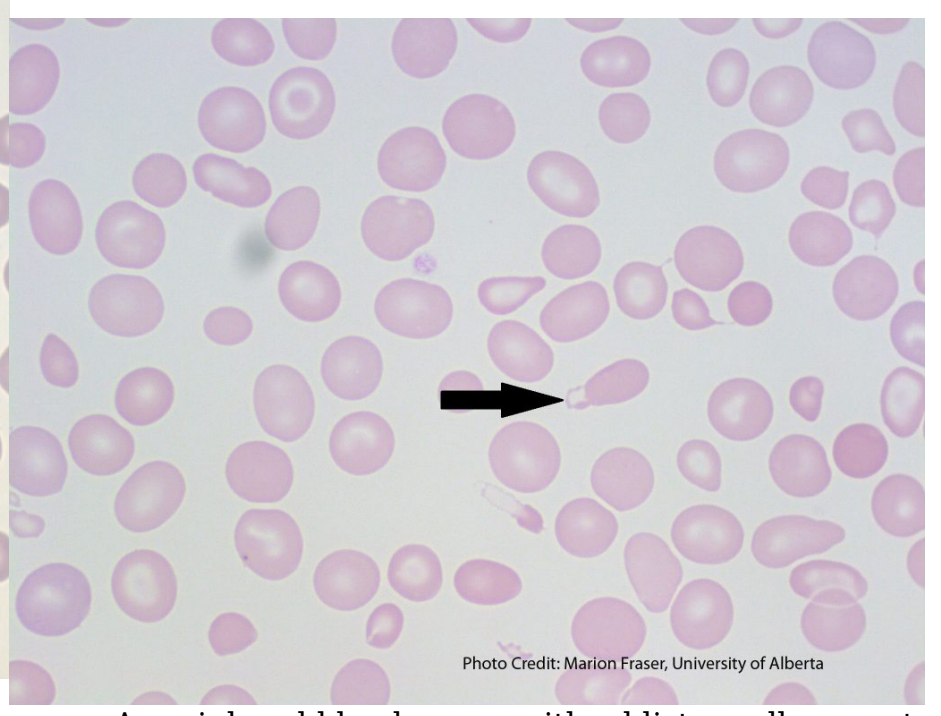

A peripheral blood smear with a blister cell present 
cell (shown with an arrow). 100x oil immersion. From MLS Collection, University of Alberta, https://doi.org/10.7939/R3H12VP5B (shown with an arrow). From MLS Collection, University of Alberta, https://doi.org/10.7939/R3HQ3SD75

\section{Cell Description:}

Bite cells are red blood cells that contain a semi-circular indent on the edge of their membrane, giving the appearance of a bite being taken out of the cell. ${ }^{1}$ Blister cells on the other hand, have cytoplasmic projections that fuse together, creating a vacuole on the edge of the membrane, giving the appearance of a blister. ${ }^{2}$

\section{Cell Formation:}

Bite and Blister cells are often seen together, and may form through various mechanisms. Red blood cells originally containing inclusions are "pitted" or removed by macrophages in the spleen, resulting in bite or

blister cells. ${ }^{3}$ When the red blood cell is impaled by fibrin strands, the membrane can reform and produce a vacuole which results in a blister cell. ${ }^{2,3}$

Bite cells can also form when a blister cell ruptures. ${ }^{4}$

\section{Associated Disease/Clinical States: ${ }^{2,4,5}$}

Microangiopathic Hemolytic Anemias (MAHAs)

Mechanical Hemolysis (i.e. mechanical heart-valves)

Heinz body hemolytic anemias (G6PD Deficiency, Thalassemia)

Note: Bite and blister cells are mainly seen in clinical states where Heinz bodies are formed. ${ }^{2}$

\section{References:}

1. Ford J. Red blood cell morphology. Int J Lab Hematol [Internet]. 2013 Mar 9 [cited 2018 Jul 
12];35(3):351-7. Available from: https://doi.org/10.1111/ijlh.12082

2. Landis-Piwowar K, Landis J, Keila P. The complete blood count and peripheral blood smear evaluation. In: Clinical laboratory hematology. 3rd ed. New Jersey: Pearson; 2015. p. 154-77.

3. Jones KW. Evaluation of cell morphology and introduction to platelet and white blood cell morphology. In: Clinical hematology and fundamentals of hemostasis. 5th ed. Philadelphia: F.A. Davis Company; 2009. p. 93-116.

4. Turgeon ML. Erythrocyte morphology and inclusions. In: Clinical hematology: theory and procedures. 4th ed. Philadelphia, PA: Lippincott Williams \& Wilkins; 1999. p. 99-111.

5. Julius CJ, Schaub CR. Hypoproliferative anemia: anemia associated with systemic diseases. In: Clinical hematology and fundamentals of hemostasis. 5th ed. Philadelphia: F.A. Davis Company; 2009. p. 280-304 


\section{7 \\ Dimorphic Population}

\section{MICHELLE TO AND VALENTIN VILLATORO}

An interactive or media element has been excluded from this version of the text. You can view it online here: https://pressbooks.library.ualberta.ca/mlsci/?p=237

Images show peripheral blood smears containing a dimorphic population (hypochromic-microcytic, and normochromic-normocytic red blood cells). From MLS Collection, University of Alberta.

Image 1: 100x oil immersion. https://doi.org/10.7939/R3T14V447

Image 2: 50x oil immersion. https://doi.org/10.7939/R3V11W18D

\section{Cell Description:}

The peripheral blood smear shows that there are two distinct red blood cell populations present. The different red blood cell populations that may be seen are normocytic/normochromic, microcytic/hypochromic, macrocytic/normochromic. ${ }^{1,2}$

\section{Cell Formation:}

The cause for the formation of a dimorphic red blood cell population varies depending on the clinical condition.

\section{Associated Disease/Clinical States: ${ }^{1-2}$}

Sideroblastic Anemia

Myelodysplastic Syndrome (MDS) 
Iron, Vitamin B12, Folate deficiency (and during the early treatment stage)

Post-transfusion

Erythropoietin Therapy

Note: $R D W>14.5 \%^{3}$

\section{References:}

1. Ford J. Red blood cell morphology. Int J Lab Hematol [Internet]. 2013 Mar 9 [cited 2018 Jul 12];35(3):351-7. Available from: https://doi.org/10.1111/ijlh.12082

2. Constantino BT. The red cell histogram and the dimorphic red cell population. Lab Med [Internet]. 2011 May 1 [cited 2018 Jul 23];42(5):300-8. Available from: http://dx.doi.org/10.1309/LMF1UY85HEKBMIWO

3. Rodak BF, Carr JH. Variations in size and color of erythrocytes. In: Clinical hematology atlas. 5th ed. St. Louis, Missouri: Elsevier Inc.; 2017. p. 89-92. 


\section{8 \\ Echinocytes (Burr Cells)}

\section{MICHELLE TO AND VALENTIN VILLATORO}

\section{Cell Description:}

The red blood cell has multiple evenly distributed projections that are of equal length that cover the entire surface of the cell. ${ }^{1}$ Cells usually have an area of central pallor. ${ }^{2}$

\section{Cell Formation:}

Commonly form due to a "glass effect" during peripheral blood smear preparation with glass slides. Glass slides can release basic substances that can induce echinocyte formation. ${ }^{3}$

Another cause of echinocyte formation is due to storage conditions. Echinocytes can naturally form in whole blood that has been stored at $4^{\circ} \mathrm{C}$ after a few days (i.e. Blood to be transfused). ${ }^{3}$

The formation of echinocytes is a reversible process and can reform a natural discoid shape. ${ }^{3}$

Echinocytes are often considered artifact from the smear making process (drying or staining) and may not be reported, depending on individual laboratory protocol.

\section{Associated Disease/Clinical States: ${ }^{1-3}$}

Artifact

Post-transfusion

Burns 
Liver Disease

Pyruvate Kinase (PK) Deficiency

Uremia

Microangiopathic Hemolytic Anemias (MAHAs)

\section{References:}

1. Ford J. Red blood cell morphology. Int J Lab Hematol [Internet]. 2013 Mar 9 [cited 2018 Jul 12];35(3):351-7. Available from: https://doi.org/10.1111/ijlh.12082

2. Rodak BF, Carr JH. Variations in shape and distribution of erythrocytes. In: Clinical hematology atlas. 5th ed. St. Louis, Missouri: Elsevier Inc.; 2017. p. 93-106.

3. Landis-Piwowar K, Landis J, Keila P. The complete blood count and peripheral blood smear evaluation. In: Clinical laboratory hematology. 3rd ed. New Jersey: Pearson; 2015. p. 154-77. 


\section{9 \\ Elliptocytes \& Ovalocytes}

\section{MICHELLE TO AND VALENTIN VILLATORO}

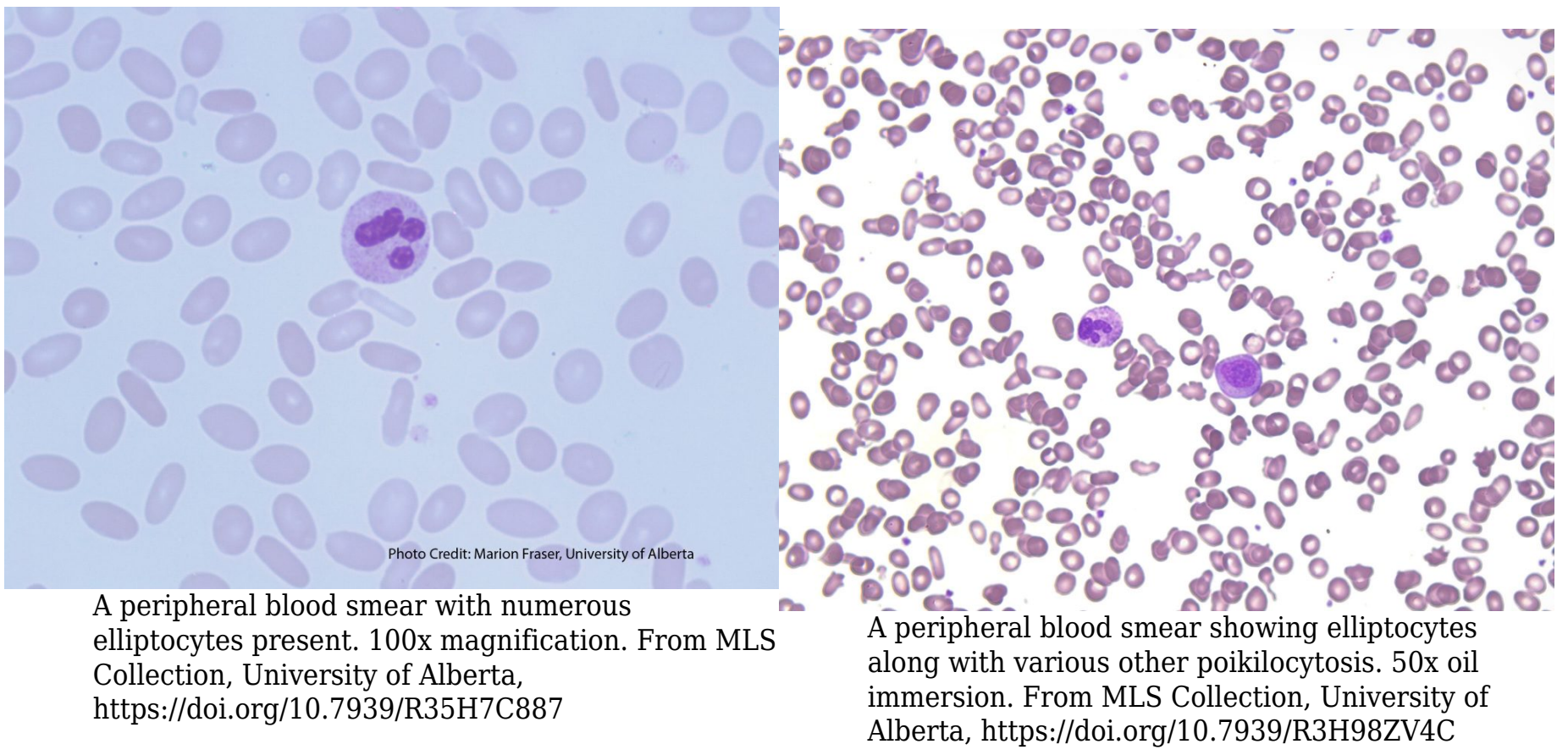

\section{Cell Description:}

Elliptocytes: Red blood cells are cigar or pencil shaped with parallel sides and an area of pallor. ${ }^{1,2}$

Ovalocytes: Are red blood cells that are oval or egg shaped. ${ }^{1,2}$

Macro-ovalocytes: Ovalocytes that are larger than a normal red blood cells. ${ }^{3}$ 
Southeast Asian Ovaloctyes: Ovalocytes show two transverse zones of pallor separated by a transverse zone of cytoplasm. ${ }^{4}$

\section{Cell Formation:}

Elliptocytes and ovalocytes are formed only after the red blood cell has reached its normal and mature morphology. Elliptical features develop over time as the cell undergoes stress in the circulation. ${ }^{1,2}$

Formation occurs due to erythrocyte membrane protein defects resulting in an increase in mechanical weakness and membrane fragility. ${ }^{1,3,5}$

Hereditary elliptocytosis occurs due to defects in the horizontal protein linkages between the membrane and cytoskeleton. ( $\alpha$-spectrin, $\square$-spectrin, protein 4.1, glycophorin $C){ }^{5,6}$

\section{Associated Disease/Clinical States: ${ }^{1,4,7}$}

\section{Elliptocytes:}

Hereditary elliptocytosis

Thalassemia

Iron deficiency Anemia
Ovalocytes:

Hereditary ovalocytosis (Southeast Asian Ovalocytosis)

Megaloblastic Anemia (Macro-ovalocytes)

\section{References:}

1. Landis-Piwowar K, Landis J, Keila P. The complete blood count and peripheral blood smear evaluation. In: Clinical laboratory hematology. 3rd ed. New Jersey: Pearson; 2015. p. 154-77.

2. Manchanda N. Anemias: red blood morphology and approach to diagnosis. In: Rodak's hematology clinical applications and principles. 5th ed. St. Louis, Missouri: Saunders; 2015. p. 284-96.

3. Jones KW. Evaluation of cell morphology and introduction to platelet and white blood cell morphology. In: Clinical hematology and fundamentals of hemostasis. 5th ed. Philadelphia: F.A. Davis 
Company; 2009. p. 93-116.

4. Ford J. Red blood cell morphology. Int J Lab Hematol [Internet]. 2013 Mar 9 [cited 2018 Jul 12];35(3):351-7. Available from: https://doi.org/10.1111/ijlh.12082

5. Gallagher PG. Abnormalities of the erythrocyte membrane. Pediatr Clin North Am [Internet]. 2013 Dec 15[cited 2018 Jun 26];;60(6):1349-62. Available from: http://www.ncbi.nlm.nih.gov/pmc/articles/PMC4155395/

6. Da Costa L, Galimand J, Fenneteau O, Mohandas N. Hereditary spherocytosis, elliptocytosis, and other red cell membrane disorders. Blood Rev [Internet]. 2013[cited 2018 Jul 24];27(4):167-78. Available from: http://www.sciencedirect.com/science/article/pii/S0268960X13000192

7. Rodak BF, Carr JH. Variations in shape and distribution of erythrocytes. In: Clinical hematology atlas. 5th ed. St. Louis, Missouri: Elsevier Inc.; 2017. p. 93-106. 


\section{0}

\section{Pyknocytes}

\section{MICHELLE TO AND VALENTIN VILLATORO}

An interactive or media element has been excluded from this version of the text. You can view it online here: https://pressbooks.library.ualberta.ca/mlsci/?p=258

Images of peripheral blood smears with pyknocytes present. Pyknocytes are indicated by the arrows. 100x oil immersion. From MLS Collection, University of Alberta.

Image 1: $\underline{\text { https://doi.org/10.7939/R33B5WQ09 }}$

Image 2: https://doi.org/10.7939/R3VX06J4H

Image 3: https://doi.org/10.7939/R3KS6JM01

\section{Cell Description:}

Pyknocytes appear as small, dark, pyknotic RBCs that lack central pallor and have an irregular, nonspherical shape.

\section{Cell Formation:}

Pyknocytes are rare, but may form as a result of red blood cell dehydration or oxidative damage.

\section{Associated Disease/Clinical States: (6 Mary Louise ch 6 pg 103)}

Pyruvate Kinase Deficiency

Glucose-6-phosphate (G6PD) Deficiency

Acute and severe hemolytic anemias 
Infantile pyknocytosis

\section{References:}

1. Turgeon ML. Normal erythrocyte lifecycle and physiology. In: Clinical hematology: theory and procedures. 4th ed. Philadelphia, PA: Lippincott Williams \& Wilkins; 1999. p. 103. 


\section{1}

\section{Rouleaux}

\section{MICHELLE TO AND VALENTIN VILLATORO}

An interactive or media element has been excluded from this version of the text. You can view it online here: https://pressbooks.library.ualberta.ca/mlsci/?p=260

Images of peripheral blood smears with rouleaux present. From MLS Collection, University of Alberta.

Image 1: 50x oil immersion. https://doi.org/10.7939/R3445HT5R

Image 2: 10x magnification. https://doi.org/10.7939/R3HQ3SD56

Image 3: 50x oil immersion. https://doi.org/10.7939/R3HM5313R

\section{Cell Description:}

Red blood cells are arranged into rows or linear chains, appearing on top of one another in a "coin stacking" fashion. The outlines of the the individual cells are usually seen. ${ }^{1,2}$

\section{Cell Formation:}

Can form naturally after blood is collected and allowed to sit for a long period of time. ${ }^{1}$

Similar morphology can be seen in the thick areas of a blood smear. ${ }^{1}$ Pathological rouleaux is only reported when seen in the thin areas of a peripheral blood smear where a differential would usually be performed. ${ }^{3}$ 
In pathological states, the increase of plasma proteins (e.g. fibrinogen, globulins) will coat the red blood cells and cause them to become "sticky" and result in rouleaux formation. ${ }^{1,4}$

\section{Associated Disease/Clinical States: ${ }^{2,5}$}

*Associated with any condition that results in the increase of plasma proteins

Acute and chronic inflammatory disorders

Plasma Cell Myeloma (Multiple Myeloma)

Polyclonal or monoclonal hyperglobulinemia

Note: Unlike with agglutination, the formation of rouleaux can be reversed with the addition of saline. ${ }^{2}$

\section{References:}

1. Landis-Piwowar K, Landis J, Keila P. The complete blood count and peripheral blood smear evaluation. In: Clinical laboratory hematology. 3rd ed. New Jersey: Pearson; 2015. p. 154-77.

2. Rodak BF, Carr JH. Variations in shape and distribution of erythrocytes. In: Clinical hematology atlas. 5th ed. St. Louis, Missouri: Elsevier Inc.; 2017. p. 93-106.

3. Turgeon ML. Erythrocyte morphology and inclusions. In: Clinical hematology: theory and procedures. 4th ed. Philadelphia, PA: Lippincott Williams \& Wilkins; 1999. p. 99-111.

4. Jones KW. Evaluation of cell morphology and introduction to platelet and white blood cell morphology. In: Clinical hematology and fundamentals of hemostasis. 5th ed. Philadelphia: F.A. Davis Company; 2009. p. 93-116.

5. Ford J. Red blood cell morphology. Int J Lab Hematol [Internet]. 2013 Mar 9 [cited 2018 Jul 12];35(3):351-7. Available from: https://doi.org/10.1111/ijlh.12082 


\section{2}

\section{Schistocytes}

\section{MICHELLE TO AND VALENTIN VILLATORO}

An interactive or media element has been excluded from this version of the text. You can view it online here: https://pressbooks.library.ualberta.ca/mlsci/?p=272

Images show peripheral blood smears with schistocytes present (indicated by the arrow). From MLS Collection, University of Alberta.

Image 1: 100x oil immersion. https://doi.org/10.7939/R34Q7R51T

Image 2: 50x oil immersion. https://doi.org/10.7939/R3N29PN8H

Image 3: https://doi.org/10.7939/R31R6NG3M

\section{Cell Description:}

Fragmented red blood cells with varying shapes and sizes. Cells often appear small, with multiple pointed and angular ends and lack an area of central pallor. ${ }^{1,2}$

\section{Cell Formation:}

Formed in circulation when a red blood cell is damaged by mechanical means (e.g. damaged by fibrin strands or mechanical heart valves). The presence of schistocytes suggests an intravascular hemolytic process is occurring ${ }^{2,3}$

\section{Associated Disease/Clinical States: ${ }^{1,2,4,5}$}

Microangiopathic Hemolytic Anemia (MAHAs) 
Macroangiopathic Hemolytic Anemias

Renal graft rejection

Severe burns

\section{References:}

1. Rodak BF, Carr JH. Variations in shape and distribution of erythrocytes. In: Clinical hematology atlas. 5th ed. St. Louis, Missouri: Elsevier Inc.; 2017. p. 93-106.

2. Ford J. Red blood cell morphology. Int J Lab Hematol [Internet]. 2013 Mar 9 [cited 2018 Jul 12];35(3):351-7. Available from: https://doi.org/10.1111/ijlh.12082

3. Landis-Piwowar K, Landis J, Keila P. The complete blood count and peripheral blood smear evaluation. In: Clinical laboratory hematology. 3rd ed. New Jersey: Pearson; 2015. p. 154-77.

4. Jones KW. Evaluation of cell morphology and introduction to platelet and white blood cell morphology. In: Clinical hematology and fundamentals of hemostasis. 5th ed. Philadelphia: F.A. Davis Company; 2009. p. 93-116.

5. Manchanda N. Anemias: red blood morphology and approach to diagnosis. In: Rodak's hematology clinical applications and principles. 5th ed. St. Louis, Missouri: Saunders; 2015. p. 284-96. 


\section{3}

Sickle Cells (Drepanocytes)

\section{MICHELLE TO AND VALENTIN VILLATORO}

An interactive or media element has been excluded from this version of the text. You can view it online here: https://pressbooks.library.ualberta.ca/mlsci/?p=278

A peripheral blood smear demonstrating sickle cells (indicated by arrows). From MLS Collection, University of Alberta.

Image 1: 100x oil immersion. https://doi.org/10.7939/R3TQ5RV8M

Image 2: 100x oil immersion. https://doi.org/10.7939/R3X05XT8X

\section{Cell Description:}

Red blood cells that lack an area of central pallor, are thin, and appear curved or S-shaped (cells resemble a sickle or crescent). The ends of the cell are pointed. ${ }^{1}$

\section{Cell Formation:}

A genetic mutation in the $\beta$ globin chain results in the production of abnormal hemoglobin $\mathrm{S}$. The mutation results in an amino acid substitution in the 6th position from glutamine to valine. Red blood cells have normal morphology under normal conditions but under hypoxic conditions (decreased oxygen tension), hemoglobin S polymerizes and causes the red blood cell to assume the characteristic sickle shape. ${ }^{2}$ Sickle cell formation causes the red blood cell to become rigid and inflexible. ${ }^{3}$

Factors that contribute to hemoglobin S polymerization and RBC sickling include:

- Low oxygen saturation

- Decreased pH

- Increased 2,3-BPG 
- Dehydration

These factors affect either the oxygenation or concentration of hemoglobin S inside the red blood cell, leading to polymerization and sickling.

Note: Formation of sickle cells can be reversible when hypoxic conditions are corrected however not all sickle cells have the ability to revert back to a normal morphology. ${ }^{2,3}$

\section{Associated Disease/Clinical States: ${ }^{1}$}

Sickle Cell Disease (Homozygous Hemoglobin S disease)

Hemoglobin SC Disease

Note: Sickle cells not usually seen in heterozygous hemoglobin S (Hemoglobin AS or Sickle Cell Trait). ${ }^{1}$

\section{References:}

1. Rodak BF, Carr JH. Variations in shape and distribution of erythrocytes. In: Clinical hematology atlas. 5th ed. St. Louis, Missouri: Elsevier Inc.; 2017. p. 93-106.

2. Landis-Piwowar K, Landis J, Keila P. The complete blood count and peripheral blood smear evaluation. In: Clinical laboratory hematology. 3rd ed. New Jersey: Pearson; 2015. p. 154-77.

3. Jones KW. Evaluation of cell morphology and introduction to platelet and white blood cell morphology. In: Clinical hematology and fundamentals of hemostasis. 5th ed. Philadelphia: F.A. Davis Company; 2009. p. 93-116. 


\section{4}

\section{Spherocytes}

\section{MICHELLE TO AND VALENTIN VILLATORO}

An interactive or media element has been excluded from this version of the text. You can view it online here: https://pressbooks.library.ualberta.ca/mlsci/?p=283

Images show peripheral blood smears with numerous spherocytes present (examples are indicated by arrows). From MLS Collection, University of Alberta.

Image 1: 100x oil immersion. $\underline{\text { https://doi.org/10.7939/R39883320 }}$

Image 2: 50x oil immersion. $\underline{\text { https://doi.org/10.7939/R3XG9FS24 }}$

\section{Cell Description:}

Round red blood cells that lack an area of central pallor. Cells often appear darker and smaller than a normocytic red blood cell. ${ }^{1}$

\section{Cell Formation:}

Formation of spherocytes in circulation occurs due to a partial loss of the red blood cell membrane. This can occur when RBCs are not fully phagocytosed by macrophages during extravascular hemolysis. ${ }^{2}$ Cellular content remains the same and this leads to a decrease in the surface to volume ratio and spherocyte formation. ${ }^{3}$

Hereditary Spherocytosis: the formation of spherocytes occurs due to the defects in the vertical protein linkages between the membrane and cytoskeleton, resulting in a loss of unsupported RBC membrane and spherocyte formation. ${ }^{4}$ 


\section{Associated Disease/Clinical States: ${ }^{1,5-7}$}

Hereditary Spherocytosis

Warm Auto-Immune Hemolytic Anemia (WAIHA)

Drug-Induced Immune Hemolytic Anemia

Allo-Immune-mediated hemolysis (delayed hemolytic transfusion reactions, Hemolytic Disease of the Fetus and Newborn)

Glucose-6-Phosphate (G6PD) Deficiency

Transfused cells (storage lesion)

Severe burns

Note: Spherocytes have an increased MCHC (>360 g/L). ${ }^{5}$

\section{References:}

1. Rodak BF, Carr JH. Variations in shape and distribution of erythrocytes. In: Clinical hematology atlas. 5th ed. St. Louis, Missouri: Elsevier Inc.; 2017. p. 93-106.

2. Doig K. Introduction to increased destruction of erythrocytes. In: Rodak's hematology clinical applications and principles. 5th ed. St. Louis, Missouri: Saunders; 2015. p. 348-66.

3. Bain BJ. Morphology of blood cells. In: Blood cells: a practical guide [Internet]. 5th ed. Chichester, UK: John Wiley \& Sons, Ltd; 2015 [cited 2018 Jul 10]: 67-185. Available from: http://doi.wiley.com/10.1002/9781118817322

4. Da Costa L, Galimand J, Fenneteau O, Mohandas N. Hereditary spherocytosis, elliptocytosis, and other red cell membrane disorders. Blood Rev [Internet]. 2013[cited 2018 Jul 24];27(4):167-78. Available from: http://www.sciencedirect.com/science/article/pii/S0268960X13000192

5. Landis-Piwowar K, Landis J, Keila P. The complete blood count and peripheral blood smear evaluation. In: Clinical laboratory hematology. 3rd ed. New Jersey: Pearson; 2015. p. 154-77. 
6. Ford J. Red blood cell morphology. Int J Lab Hematol [Internet]. 2013 Mar 9 [cited 2018 Jul 12];35(3):351-7. Available from: https://doi.org/10.1111/ijlh.12082

7. Turgeon ML. Erythrocyte morphology and inclusions. In: Clinical hematology: theory and procedures. 4th ed. Philadelphia, PA: Lippincott Williams \& Wilkins; 1999. p. 99-111. 


\section{5}

\section{Stomatocytes}

\section{MICHELLE TO AND VALENTIN VILLATORO}

\section{Cell Description:}

Red blood cells that appear to have an area of central pallor that is slit-like (stoma) instead of circular. ${ }^{1}$

Cells are normal in size but lack it's normal biconcavity. ${ }^{2}$ By using electron microscopy, cells instead appear "cup" or "bowl” shaped. ${ }^{3}$

\section{Cell Formation:}

Cell formation is due to a membrane defects (acquired or inherited) that results alterations in cell volume. Both an increase (hydrocytosis) and a decrease (xerocytosis) in cell volume can cause the production of stomatocytes. $^{2}$

\section{Associated Disease/Clinical States: ${ }^{1,2,4,5}$}

Hereditary Stomatocytosis

Artifact

Alcoholism

Liver disease

$\mathrm{Rh}$ Null Disease

Drugs (effects are often reversible) 


\section{References:}

1. Rodak BF, Carr JH. Variations in shape and distribution of erythrocytes. In: Clinical hematology atlas. 5th ed. St. Louis, Missouri: Elsevier Inc.; 2017. p. 93-106.

2. Jones KW. Evaluation of cell morphology and introduction to platelet and white blood cell morphology. In: Clinical hematology and fundamentals of hemostasis. 5th ed. Philadelphia: F.A. Davis Company; 2009. p. 93-116.

3. Bain BJ. Morphology of blood cells. In: Blood cells: a practical guide [Internet]. 5th ed. Chichester, UK: John Wiley \& Sons, Ltd; 2015 [cited 2018 Jul 10]: 67-185. Available from: http://doi.wiley.com/10.1002/9781118817322

4. Landis-Piwowar K, Landis J, Keila P. The complete blood count and peripheral blood smear evaluation. In: Clinical laboratory hematology. 3rd ed. New Jersey: Pearson; 2015. p. 154-77.

5. Ford J. Red blood cell morphology. Int J Lab Hematol [Internet]. 2013 Mar 9 [cited 2018 Jul 12];35(3):351-7. Available from: https://doi.org/10.1111/ijlh.12082 


\section{6 \\ Target Cells (Codocytes)}

\section{MICHELLE TO AND VALENTIN VILLATORO}

An interactive or media element has been excluded from this version of the text. You can view it online here: https://pressbooks.library.ualberta.ca/mlsci/?p=292

Images show peripheral blood smears with numerous target cells present (examples are indicated by arrows). From MLS Collection, University of Alberta.

Image 1: 100x oil immersion. https://doi.org/10.7939/R3R49GR23

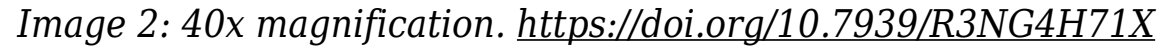

Image 3. 60x oil immersion. https://doi.org/10.7939/R3R78644B

\section{Cell Description:}

Target cells adopt a "bullseye" morphology where hemoglobin is concentrated in the center and on the periphery with a colourless zone in between the two areas. Other target cells may also look folded or bell shaped. ${ }^{1-3}$

Note: The target cell membrane is thinner than normal cells. ${ }^{1,4}$

\section{Cell Formation:}

Liver Disease: membrane cholesterol concentration is reduced, decreasing the tensile strength of the membrane, resulting in target cell formation. ${ }^{2,3,5}$

Artifact: Target cell formation occurs when blood smears are made when humidity is high. ${ }^{1}$ 
Hemoglobinopathies: There is a uneven distribution of hemoglobin within the cell, and an increased surface area to volume ratio. ${ }^{1}$

Note: Target cells have an increased surface area to volume ratio and decreased osmotic fragility. ${ }^{1,3}$

\section{Associated Disease/Clinical States: ${ }^{1,2,5}$}

Hemoglobinopathies (Hemoglobin C Disease, Sickle cell Disease, Thalassemia, etc.)

Iron deficiency anemia

Obstructive Liver disease

Splenectomy

Artifact

\section{References:}

1. Landis-Piwowar K, Landis J, Keila P. The complete blood count and peripheral blood smear evaluation. In: Clinical laboratory hematology. 3rd ed. New Jersey: Pearson; 2015. p. 154-77.

2. Rodak BF, Carr JH. Variations in shape and distribution of erythrocytes. In: Clinical hematology atlas. 5th ed. St. Louis, Missouri: Elsevier Inc.; 2017. p. 93-106.

3. Jones KW. Evaluation of cell morphology and introduction to platelet and white blood cell morphology. In: Clinical hematology and fundamentals of hemostasis. 5th ed. Philadelphia: F.A. Davis Company; 2009. p. 93-116.

4. Bain BJ. Morphology of blood cells. In: Blood cells: a practical guide [Internet]. 5th ed. Chichester, UK: John Wiley \& Sons, Ltd; 2015 [cited 2018 Jul 10]: 67-185. Available from: http://doi.wiley.com/10.1002/9781118817322

5. Turgeon ML. Erythrocyte morphology and inclusions. In: Clinical hematology: theory and procedures. 4th ed. Philadelphia, PA: Lippincott Williams \& Wilkins; 1999. p. 99-111. 


\section{7}

\section{Tear Cells (Dacrocytes, Teardrops)}

\section{MICHELLE TO AND VALENTIN VILLATORO}

An interactive or media element has been excluded from this version of the text. You can view it online here: https://pressbooks.library.ualberta.ca/mlsci/?p=297

Images show peripheral blood smears with numerous tear cells (examples indicated by arrows). From MLS Collection, University of Alberta.

Image 1: 50x oil immersion. https://doi.org/10.7939/R37S7J768

Image 2: https://doi.org/10.7939/R3D21S07J

Image 3: https://doi.org/10.7939/R38P5VR5R

\section{Cell Description:}

Red blood cells that are teardrop or pear shaped with one blunt projection. ${ }^{1}$ The size of these cells are variable. $^{2}$

\section{Cell Formation:}

Red blood cells with inclusions: Teardrop cells form from these cells when the cells attempt to pass through the microcirculation resulting in the pinching the cell as the part containing the inclusion is left behind. $^{2}$

Myelophthisis: displacement of normal hematopoietic tissue in the bone marrow by abnormal cells (malignancies) or fibrosis, leading to bone marrow crowding and pinching of RBCs as they as pushed out of the bone marrow. 


\section{Associated Disease/Clinical States: ${ }^{1-3}$}

Primary myelofibrosis

Thalassemia

Megaloblastic Anemia

Sideroblastic Anemia

Myelophthisic Anemia

Drug-induced Heinz body formation

\section{References:}

1. Rodak BF, Carr JH. Variations in shape and distribution of erythrocytes. In: Clinical hematology atlas. 5th ed. St. Louis, Missouri: Elsevier Inc.; 2017. p. 93-106, 289.

2. Jones KW. Evaluation of cell morphology and introduction to platelet and white blood cell morphology. In: Clinical hematology and fundamentals of hemostasis. 5th ed. Philadelphia: F.A. Davis Company; 2009. p. 93-116.

3. Bain BJ. Morphology of blood cells. In: Blood cells: a practical guide [Internet]. 5th ed. Chichester, UK: John Wiley \& Sons, Ltd; 2015 [cited 2018 Jul 10]: 67-185. Available from: http://doi.wiley.com/10.1002/9781118817322 


\section{III \\ RED BLOOD CELLS: ABNORMAL RBC INCLUSIONS}




\section{8 \\ Basophilic Stippling}

MICHELLE TO AND VALENTIN VILLATORO

An interactive or media element has been excluded from this version of the text. You can view it online here: https://pressbooks.library.ualberta.ca/mlsci/?p=302

Images show peripheral blood smears with basophilic stippling in the red blood cells (indicated by arrows). From MLS Collection, University of Alberta.

Image 1: 100x oil immersion. https://doi.org/10.7939/R3G15TS2N

Image 2: 100x oil immersion. https://doi.org/10.7939/R3RJ4993X

Image 3: 100x oil immersion. https://doi.org/10.7939/R3J960R3H

\section{Appearance:}

Multiple dark blue-purple granules that are distributed throughout the red blood cell. Granules can appear coarse, fine, round, and/or irregularly shaped, and are present in numerous numbers. ${ }^{1,2}$ Typically, only coarse basophilic stippling is reported.

\section{Inclusion composition: ${ }^{1-3}$}

Aggregates of ribonucleic Acid (RNA)

\section{Associated Disease/Clinical States: ${ }^{1,2}$}

Lead toxicity 
Thalassemia

Abnormal heme synthesis

\section{References:}

1. Landis-Piwowar K, Landis J, Keila P. The complete blood count and peripheral blood smear evaluation. In: Clinical laboratory hematology. 3rd ed. New Jersey: Pearson; 2015. p. 154-77.

1. Rodak BF, Carr JH. Variations in shape and distribution of erythrocytes. In: Clinical hematology atlas. 5th ed. St. Louis, Missouri: Elsevier Inc.; 2017. p. 93-106.

3. Bain BJ. Morphology of blood cells. In: Blood cells: a practical guide [Internet]. 5th ed. Chichester, UK: John Wiley \& Sons, Ltd; 2015 [cited 2018 Jul 10]: 67-185. Available from: http://doi.wiley.com/10.1002/9781118817322 


\section{9}

Cabot Rings

MICHELLE TO AND VALENTIN VILLATORO

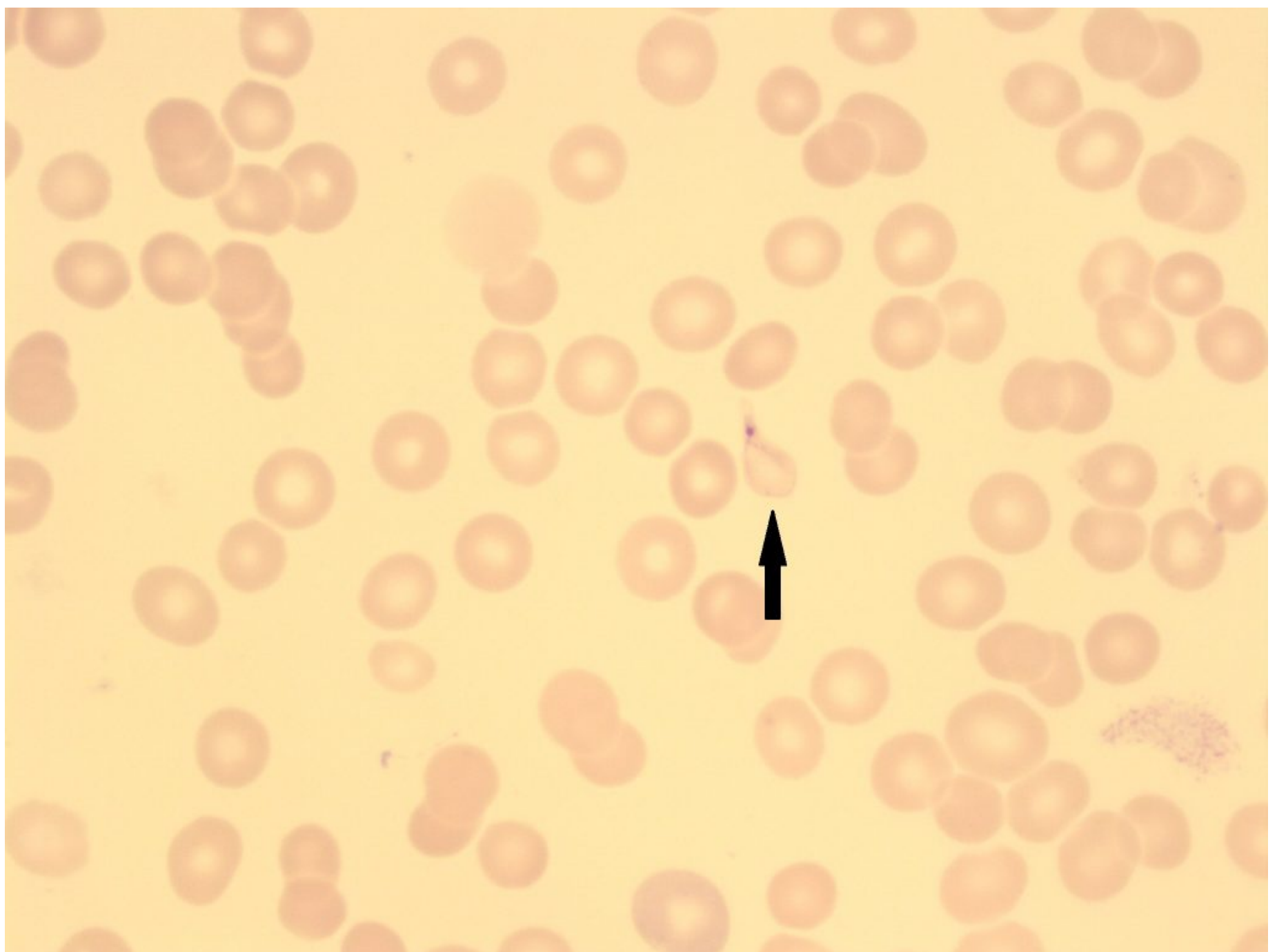

An image from a peripheral blood smear showing a cabot ring. 100x oil immersion. From MLS Collection, University of Alberta, https://doi.org/10.7939/R3B854027

\section{Appearance:}

Red-purple inclusions that appear as a loop, ring, or figure-eight shape and span the diameter of the red blood cell. 1-2 cabot rings may be seen in a single cell. ${ }^{1}$ 
Note: Finding is rare, and not to be confused with malaria.

\section{Inclusion composition: ${ }^{1}$}

Remnant microtubules of mitotic spindle

\section{Associated Disease/Clinical States: ${ }^{1-3}$}

Myelodysplastic Syndrome (MDS; Dyserythropoiesis)

Megaloblastic Anemia

Lead poisoning

\section{References:}

1. Rodak BF, Carr JH. Inclusions in erythrocytes. In: Clinical hematology atlas. 5th ed. St. Louis, Missouri: Elsevier Inc.; 2017. p. 107-14.

2. Landis-Piwowar K, Landis J, Keila P. The complete blood count and peripheral blood smear evaluation. In: Clinical laboratory hematology. 3rd ed. New Jersey: Pearson; 2015. p. 154-77.

3. Turgeon ML. Erythrocyte morphology and inclusions. In: Clinical hematology: theory and procedures. 4th ed. Philadelphia, PA: Lippincott Williams \& Wilkins; 1999. p. 99-111. 


\section{0}

Heinz Bodies

\section{MICHELLE TO AND VALENTIN VILLATORO}

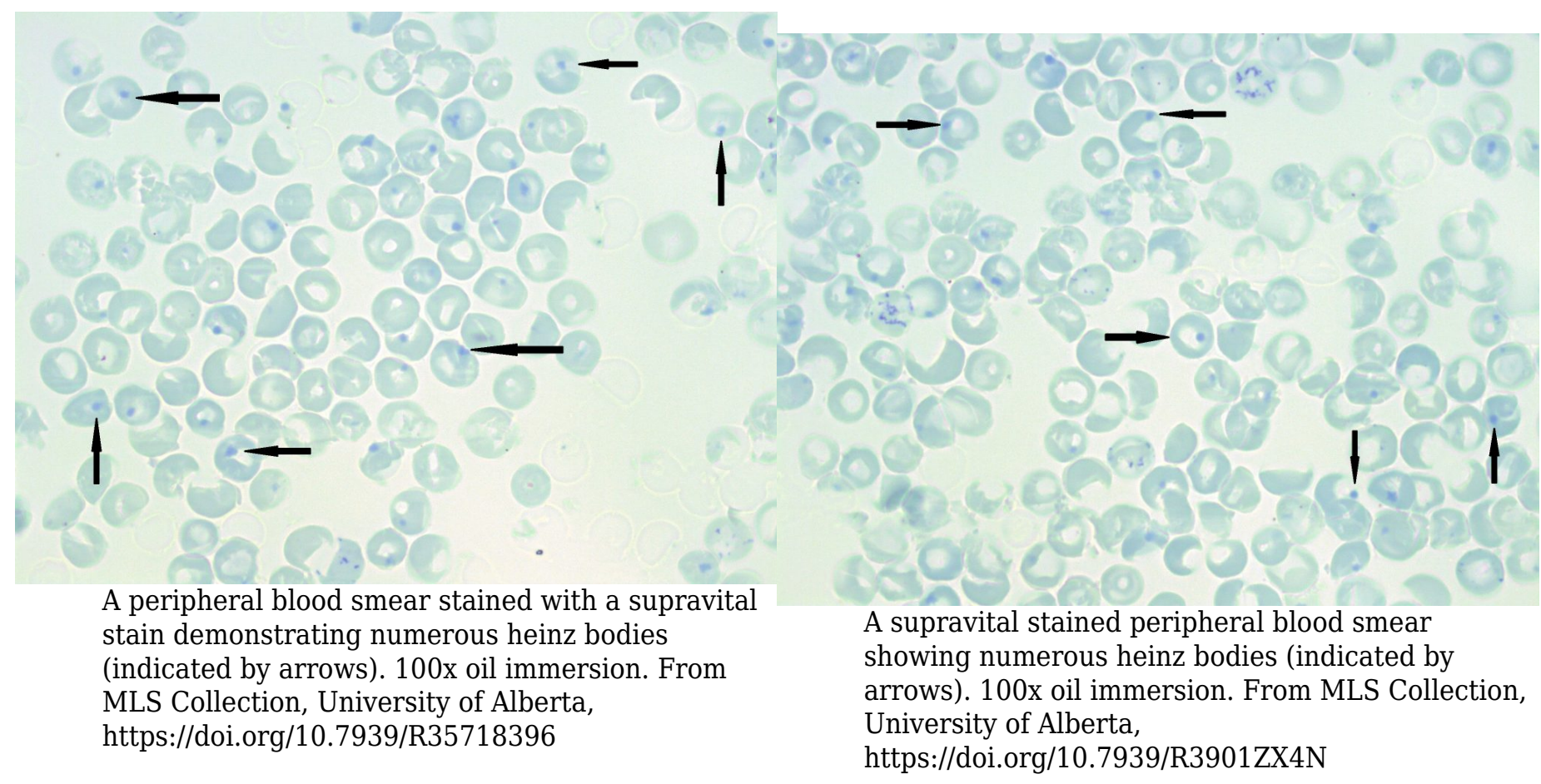

\section{Appearance:}

Inclusions are not visible on Wright or Romanowsky-stained blood smears. Inclusions can only be visualized with supravital stains. After staining, Heinz body inclusions appear dark blue-purple and are located at the periphery of the red blood cell at the membrane. The inclusions are round and look as if they are being ejected out of the cell. ${ }^{1,2}$

Note: Heinz bodies are usually not seen, as they are normally removed by splenic macrophages. ${ }^{3}$ Their presence indicates an increase in hemoglobin denaturation and precipitation, seen in numerous conditions that result in hemoglobin instability, oxidative damage, or excess globin chains. 


\section{Inclusion composition: ${ }^{1,2}$}

Denatured or precipitated hemoglobin

\section{Associated Disease/Clinical States: ${ }^{1,2}$}

Glucose-6-phosphate dehydrogenase (G6PD) Deficiency

Hemoglobinopathies (may result in the formation of unstable hemoglobins)

Thalassemia

Post-splenectomy

Oxidizing drugs

Note: Appear in conditions where unstable hemoglobin can form. ${ }^{2}$

\section{References:}

1. Landis-Piwowar K, Landis J, Keila P. The complete blood count and peripheral blood smear evaluation. In: Clinical laboratory hematology. 3rd ed. New Jersey: Pearson; 2015. p. 154-77.

2. Rodak BF, Carr JH. Inclusions in erythrocytes. In: Clinical hematology atlas. 5th ed. St. Louis, Missouri: Elsevier Inc.; 2017. p. 107-14.

3. Bain BJ. Important supplementary tests. In: Blood cells: a practical guide [Internet]. 5th ed. Chichester, UK: John Wiley \& Sons, Ltd; 2015 [cited 2018 Jul 10]: 277-94. Available from: http://doi.wiley.com/10.1002/9781118817322 


\section{1 \\ Hemoglobin $\mathrm{H}(\mathrm{Hb} \mathrm{H})$}

\section{MICHELLE TO AND VALENTIN VILLATORO}

An interactive or media element has been excluded from this version of the text. You can view it online here: https://pressbooks.library.ualberta.ca/mlsci/?p=317

Images show supravital stained peripheral blood smears with numerous hemoglobin $H$ inclusions (examples indicated by arrows). Note the golf ball-like appearance of the red blood cells. From MLS Collection, University of Alberta.

Image 1: 50x oil immersion. https://doi.org/10.7939/R3GM8243H

Image 2: 100x oil immersion. https://doi.org/10.7939/R33F4M37Z

\section{Appearance:}

Hemoglobin $\mathrm{H}$ inclusions can only be visualized with supravital stains and not Wright or Romanowsky stains. With supravital stains, such as Brillian Cresyl Blue, the red blood cells are covered with numerous small, dark blue dots that give the cells a "golf ball" or "raspberry" appearance. ${ }^{1,2}$

\section{Inclusion composition: ${ }^{1,2}$}

Hemoglobin $\mathrm{H}$ is made up of $4 \square$ globin chains in a tetramer formation. Hemoglobin $\mathrm{H}$ is unstable and will precipitate over time in the RBC, leading to Heinz Body formation. Precipitation can be induced using supravital stains, and can be used to visualize Hemoglobin $\mathrm{H}$ inclusions.

\section{Associated Disease/Clinical States: ${ }^{1,2}$}

Hemoglobin H Disease 


\section{References:}

1. Randolph TR. Thalassemia. In: Clinical laboratory hematology. 3rd ed. New Jersey: Pearson; 2015. p. 251-276.

2. Rodak BF, Carr JH. Inclusions in erythrocytes. In: Clinical hematology atlas. 5th ed. St. Louis, Missouri: Elsevier Inc.; 2017. p. 107-14. 


\section{2}

Hemoglobin C Crystals

\section{MICHELLE TO AND VALENTIN VILLATORO}

\section{Appearance: ${ }^{1,2}$}

Dark red hexagonal crystals with blunt ends. The crystal is prominent within the red blood cell, or may be found extra-cellularly. Usually only one crystal is present per single cell. Hemoglobin C crystals are rarely found, as the spleen will remove them from circulation, though patients who have undergone a splenectomy have may numerous hemoglobin $\mathrm{C}$ crystals present on their peripheral blood smear.

\section{Inclusion composition: ${ }^{2}$}

Crystalized Hemoglobin C.

\section{Associated Disease/Clinical States: ${ }^{1}$}

Homozygous Hemoglobin C Disease

\section{References:}

1. Rodak BF, Carr JH. Variations in shape and distribution of erythrocytes. In: Clinical hematology atlas. 5th ed. St. Louis, Missouri: Elsevier Inc.; 2017. p. 93-106.

2. Jones KW. Evaluation of cell morphology and introduction to platelet and white blood cell morphology. In: Clinical hematology and fundamentals of hemostasis. 5th ed. Philadelphia: F.A. Davis Company; 2009. p. 93-116. 


\section{3 \\ Hemoglobin SC Crystals}

\section{MICHELLE TO AND VALENTIN VILLATORO}

\section{Appearance:}

Crystals appear as a combination of sickle cells and hemoglobin C crystals. They are dark red inclusions with blunt ended projections. ${ }^{1}$ The crystals are longer than Hemoglobin C crystals, but shorter and thicker than Hemoglobin S.

Inclusion composition: ${ }^{1}$

Hemoglobin S and hemoglobin C

\section{Associated Disease/Clinical States: ${ }^{1}$}

Hemoglobin SC Disease (compound heterozygosity)

\section{References:}

1. Rodak BF, Carr JH. Variations in shape and distribution of erythrocytes. In: Clinical hematology atlas. 5th ed. St. Louis, Missouri: Elsevier Inc.; 2017. p. 93-106. 


\section{4}

Howell-Jolly Bodies

\section{MICHELLE TO AND VALENTIN VILLATORO}

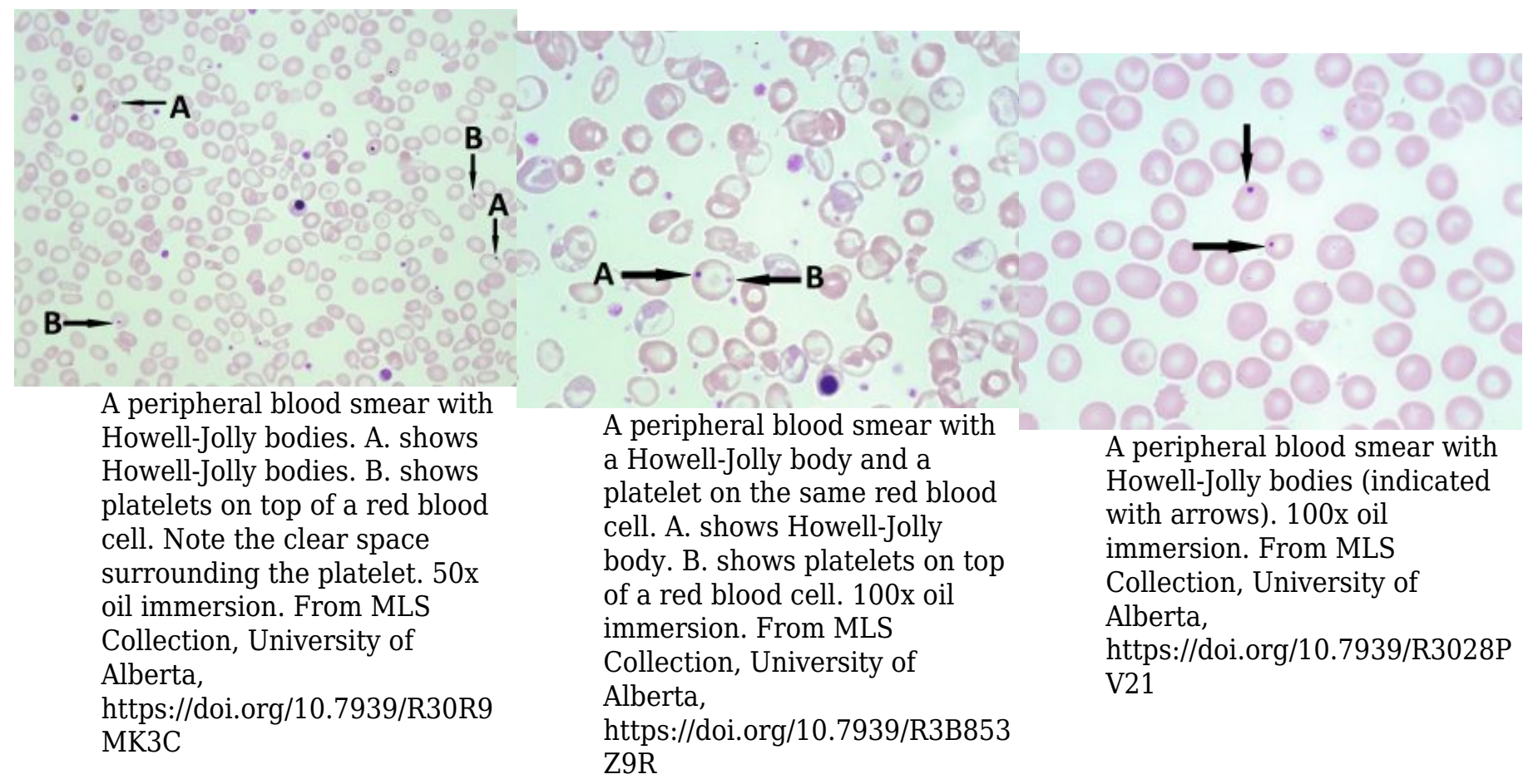

\section{Appearance:}

Under Wright/Romanowksy stains, Howell-Jolly Bodies appear as dark blue/purple round inclusions located at the periphery of the RBC. They usually present as a single inclusion inside the cell. HowellJolly Bodies are also visible under supravital stains. ${ }^{1-4}$

\section{Inclusion composition: ${ }^{2,3}$}

Nuclear fragments/remnants made up of DNA ${ }^{1-4}$ 


\section{Associated Disease/Clinical States:}

Thalassemia

Megaloblastic Anemia

Myelodysplastic Syndrome

Post-splenectomy

\section{References:}

1. Landis-Piwowar K, Landis J, Keila P. The complete blood count and peripheral blood smear evaluation. In: Clinical laboratory hematology. 3rd ed. New Jersey: Pearson; 2015. p. 154-77.

2. Jones KW. Evaluation of cell morphology and introduction to platelet and white blood cell morphology. In: Clinical hematology and fundamentals of hemostasis. 5th ed. Philadelphia: F.A. Davis Company; 2009. p. 93-116.

3. Fritsma GA. Bone marrow examination. In: Rodak's hematology clinical applications and principles. 5th ed. St. Louis, Missouri: Saunders; 2015. p. 253-68.

4. Ford J. Red blood cell morphology. Int J Lab Hematol [Internet]. 2013 Mar 9 [cited 2018 Jul 12];35(3):351-7. Available from: https://doi.org/10.1111/ijlh.12082 


\section{5}

\section{Pappenheimer Bodies (Siderotic Granules)}

MICHELLE TO AND VALENTIN VILLATORO

An iron stained peripheral blood smear with pappenheimer bodies present (indicated with arrows). Perls Prussian Blue. 50x oil immersion. From MLS Collection, University of Alberta, https://doi.org/10.7939/R3FN1173T

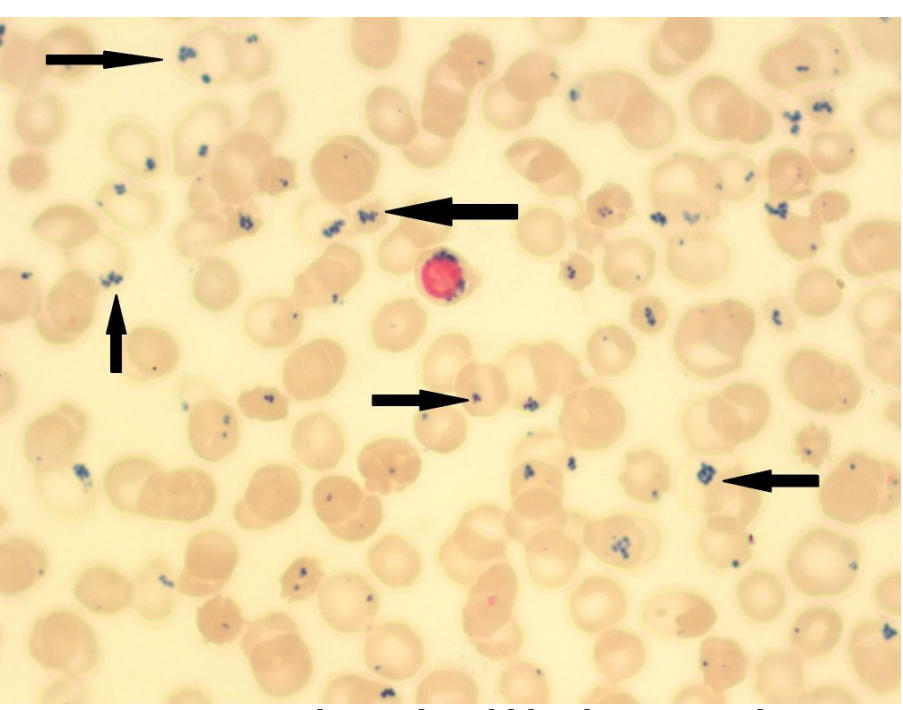

An iron stained peripheral blood smear with pappenheimer bodies present (indicated with arrows). Perls Prussian Blue. 50x oil immersion. From MLS Collection, University of Alberta, https://doi.org/10.7939/R36689100

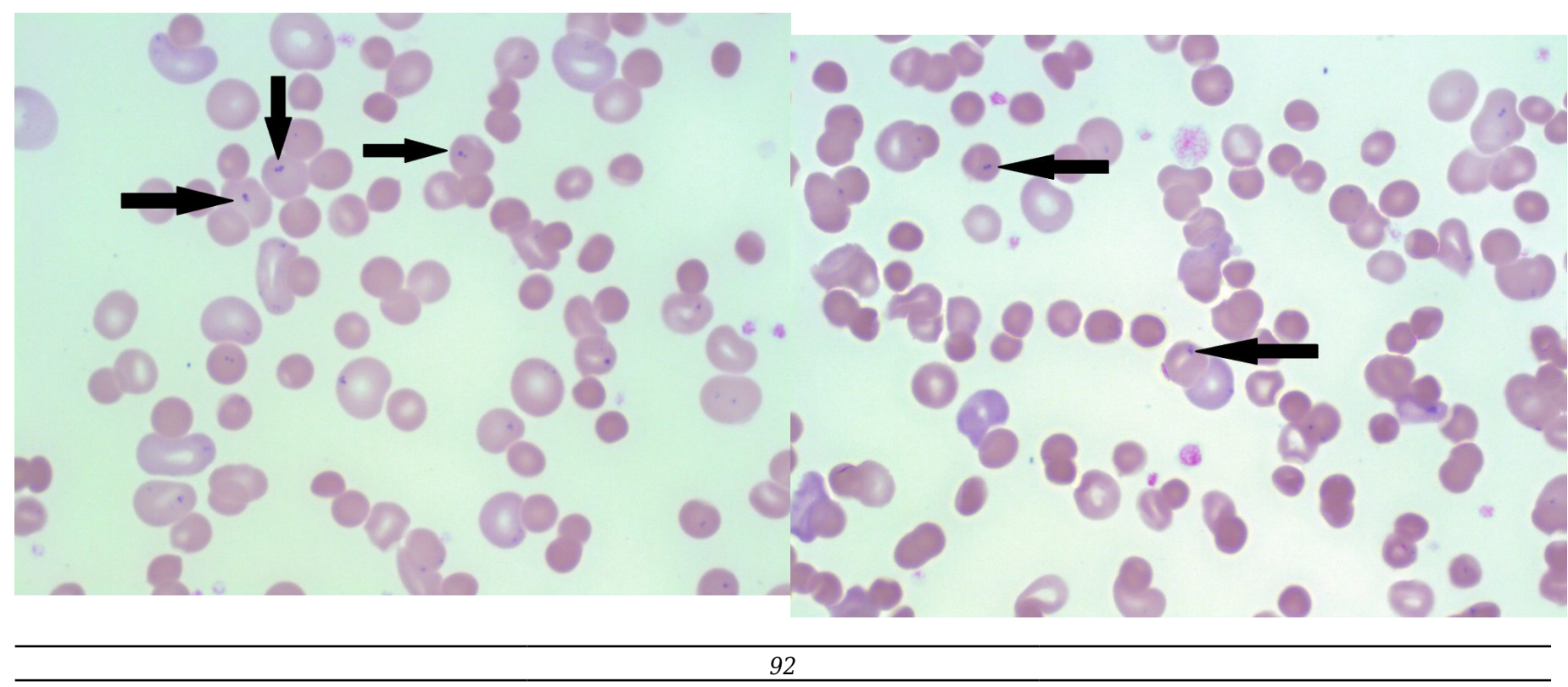


A peripheral blood smear with pappenheimer bodies present (indicated with arrows). 100x oil immersion. From MLS Collection, University of Alberta, https://doi.org/10.7939/R35X25V0R
A peripheral blood smear with pappenheimer bodies present (indicated with arrows). 100x oil immersion. From MLS Collection, University of Alberta, https://doi.org/10.7939/R3251G16Q

\section{Appearance:}

Inclusions are visible under both Wright/Romanowsky stains and Perls Prussian Blue stain. Pappenheimer inclusions appear as clusters of fine and irregular granules located at the periphery of the red blood cell. ${ }^{1-3}$

\section{Inclusion composition: ${ }^{3}$}

Iron

\section{Associated Disease/Clinical States: ${ }^{1,2}$}

Splenectomy

Sideroblastic Anemia

Thalassemia

Sickle Cell Disease

Hemachromatosis

\section{References:}

1. Landis-Piwowar K, Landis J, Keila P. The complete blood count and peripheral blood smear evaluation. In: Clinical laboratory hematology. 3rd ed. New Jersey: Pearson; 2015. p. 154-77.

2. Jones KW. Evaluation of cell morphology and introduction to platelet and white blood cell morphology. In: Clinical hematology and fundamentals of hemostasis. 5th ed. Philadelphia: F.A. Davis Company; 2009. p. 93-116. 
3. Rodak BF, Carr JH. Inclusions in erythrocytes. In: Clinical hematology atlas. 5th ed. St. Louis, Missouri: Elsevier Inc.; 2017. p. 107-14. 


\section{6}

\section{Bacteria \& Fungi}

\section{MICHELLE TO AND VALENTIN VILLATORO}

An interactive or media element has been excluded from this version of the text. You can view it online here: https://pressbooks.library.ualberta.ca/mlsci/?p=343

Images show peripheral blood smears with bacteria present. Neutrophils show toxic changes (toxic vacuolation and granulation are most prominent) and contain ingested bacteria. Bacteria is also present extracellularly. From MLS Collection, University of Alberta.

Image 1: 50x oil immersion. https://doi.org/10.7939/R3NV99S2S

Image 2: 100x oil immersion. https://doi.org/10.7939/R3J38KZ9T

Image 3: 100x oil immersion. https://doi.org/10.7939/R38K75COV

\section{Appearance:}

The morphology of a microorganism depends on the type of microorganism (fungi or bacteria) present in the blood. Can be seen extracellularly or intracellularly when patient is septic. ${ }^{1}$

\section{Organisms: ${ }^{1}$}

\section{Fungi:}

Yeast

Histoplasma capsulatum

Cryptococcus neoformans

\section{Bacteria:}

Clostridium perfringens

Bartonella bacilliformis

Cocci

Other Bacilli/Rods 


\section{References:}

1. Smith LA. Hemolytic anemia: nonimmune defects. In: Clinical laboratory hematology. 3rd ed. New Jersey: Pearson; 2015. p. 372-87. 


\section{7}

\section{Malaria}

\section{MICHELLE TO AND VALENTIN VILLATORO}

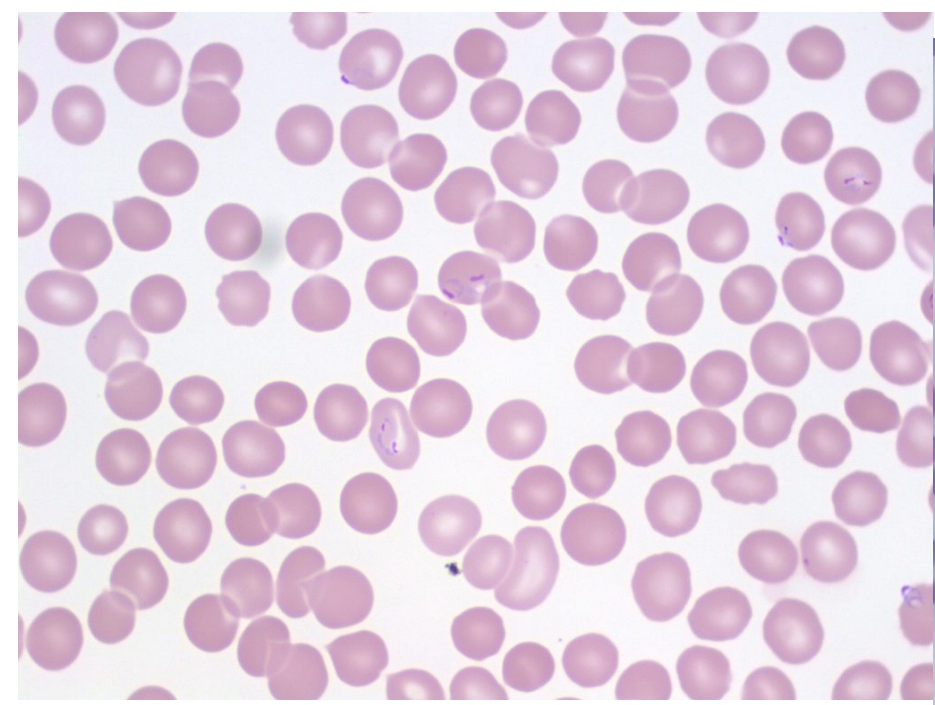

An image from a peripheral blood smear showing multiple malarial rings (Plasmodium falciparum) inside red blood cells. From MLS Collection, University of Alberta,

https://doi.org/10.7939/R3891263S

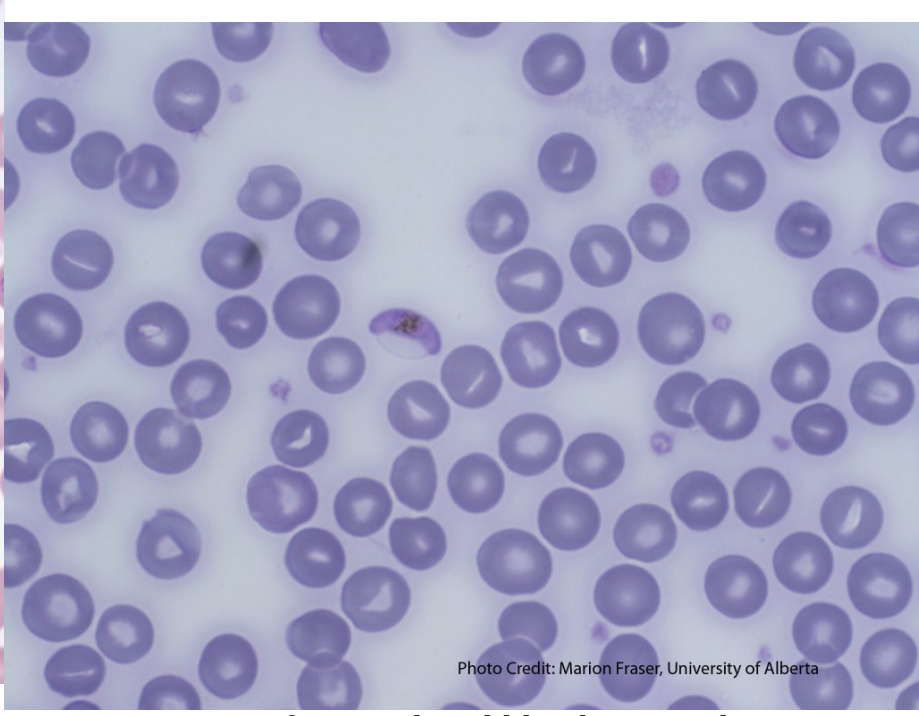

An image of a peripheral blood smear showing a crescent-shaped gametocyte (characteristic of Plasmodium falciparum). From MLS Collection, University of Alberta, https://doi.org/10.7939/R30R9MK4V

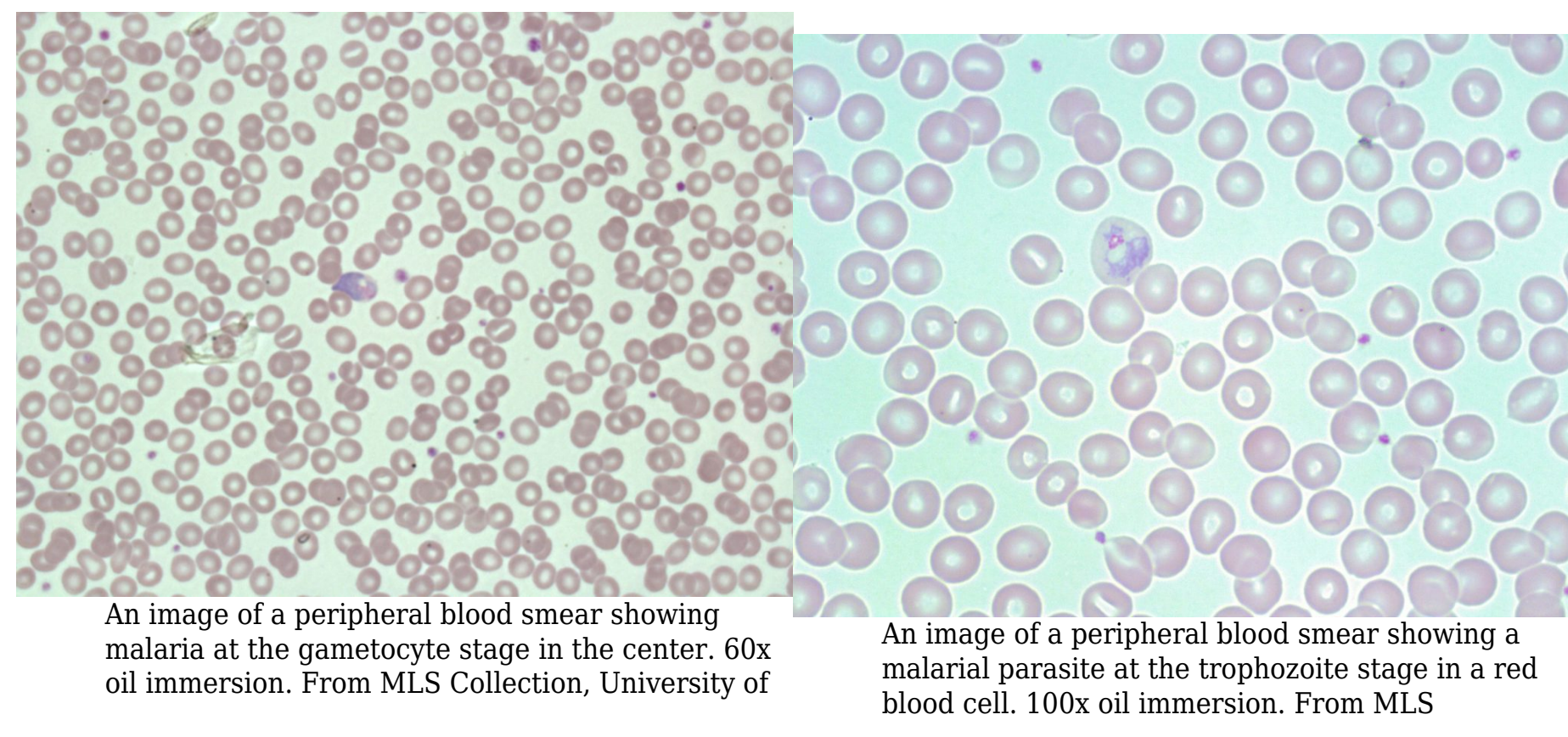




\section{Appearance:}

The morphology of malarial parasites seen in the red blood cell varies depending on the stage of maturation and species present. Malaria can appear as rings, trophozoites, schizonts, and gametocytes. Ring forms appear as a pale blue ring with a pink/purple chromatin dot, and more than one may be present in a single red blood cell. Malarial parasites are most often seen intracellular to the red blood cell with various forms. ${ }^{1}$

Parasites can be visualized using the Giemsa stain during the screening of thin and thick smears. ${ }^{1}$

Note 1: Banana shaped gametocytes seen are characteristically in Plasmodium falciparum infections.

Note 2: Malarial rings may be confused with platelets when the appear on top of a red blood cell. Platelets may be differentiated by a showing a slight clearing or halo around the platelet. ${ }^{2}$

\section{Organisms: ${ }^{1}$}

The malarial parasite is spread to humans by the female Anopheles sp. mosquito.

\section{Malaria parasites: ${ }^{1,2}$}

Plasmodium falciparum

Plasmodium vivax

Plasmodium ovale

Plasmodium malariae

Plasmodium knowlesi 


\section{References:}

1. Keohane EM. Extrinsic defects leading to increased erythrocyte destruction - nonimmune causes. In: Rodak's hematology clinical applications and principles. St. Louis, Missouri: Saunders; 2015. p. 394-410.

2. Rodak BF, Carr JH. Microorganisms. In: Clinical hematology atlas. 5th ed. St. Louis, Missouri: Elsevier Inc.; 2017. p. 195-202. 


\section{8}

\section{Babesia}

\section{MICHELLE TO AND VALENTIN VILLATORO}

\section{Appearance:}

Like malaria, Babesia species can be seen both intracellularly and extracellularly and visualed with the Giemsa stain. Babesia parasites appear as ring forms in the red blood cell with variable morphology. ${ }^{1}$

Note: Tetrad of rings may appear as a "maltese cross".

\section{Organisms:}

The Babesia microti parasite is carried by the Ixodes scapularis tick. ${ }^{1}$ Humans are incidental dead-end hosts of Babesia.

\section{References:}

1. Keohane EM. Extrinsic defects leading to increased erythrocyte destruction - nonimmune causes. In: Rodak's hematology clinical applications and principles. 5th ed. St. Louis, Missouri: Saunders; 2015. p. 394-410. 


\section{9}

\section{Trypanosomes}

\section{MICHELLE TO AND VALENTIN VILLATORO}

An interactive or media element has been excluded from this version of the text. You can view it online here: https://pressbooks.library.ualberta.ca/mlsci/?p=359

Images of peripheral blood smears showing C shaped trypanosomes (center). From MLS Collection, University of Alberta.

Image 1: 50x oil immersion. https://doi.org/10.7939/R3QZ22Z5K

Image 2: 100x oil immersion. https://doi.org/10.7939/R3M61C52N

\section{Appearance:}

Hemoflagellates that are often visualized using Giemsa stain during screening of thin and thick smears, though they are visible by regular Romanowsky staining procedures. ${ }^{1}$

Trypomastigotes appear C or U shaped in the peripheral blood, usually seen extracellular to the red blood cells. ${ }^{2}$

\section{Organisms:}

The Reduviid bug ("kissing bug") carries Trypanosoma cruzi in it's gut where it matures. During a blood meal, the Reduviid bug releases T.cruzi via feces onto the feeding sites or mucous membranes where it can cause infection in the bloodstream. ${ }^{2}$ 
Trypanosoma cruzi is the causative agent of Chagas Disease. ${ }^{2}$

\section{References:}

1. Rodak BF, Carr JH. Microorganisms. In: Clinical hematology atlas. 5th ed. St. Louis, Missouri: Elsevier Inc.; 2017. p. 195-202.

2. Ahmad N, Drew WL, Lagunoff M, Pottinger P, Reller LB, Sterling CR. Sarcomastigophora-the amebas. In: Ryan KJ, Ray CG, editors. Sherris medical microbiology. 6th ed. McGraw-Hill Education; 2014. p. 823-44. 


\section{IV \\ RED BLOOD CELLS: HYPOCHROMIC, MICROCYTIC ANEMIAS}




\section{0 \\ Iron Deficiency Anemia (IDA)}

\section{MICHELLE TO AND VALENTIN VILLATORO}

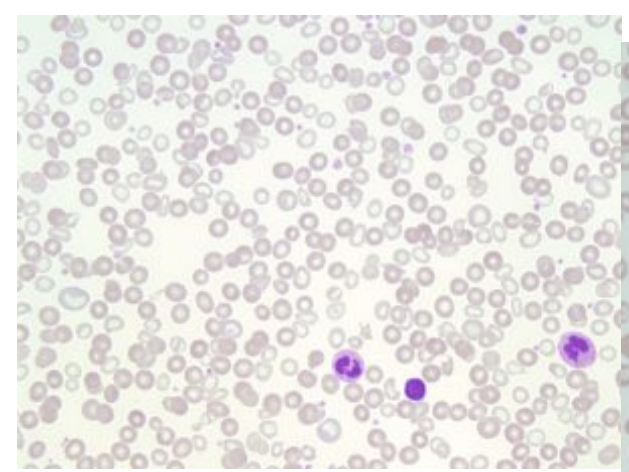

An image from a peripheral blood smear demonstrating hypochromic and microcytic red blood cells. 50x oil immersion. From MLS Collection, University of Alberta, https://doi.org/10.7939/R3P844 99C

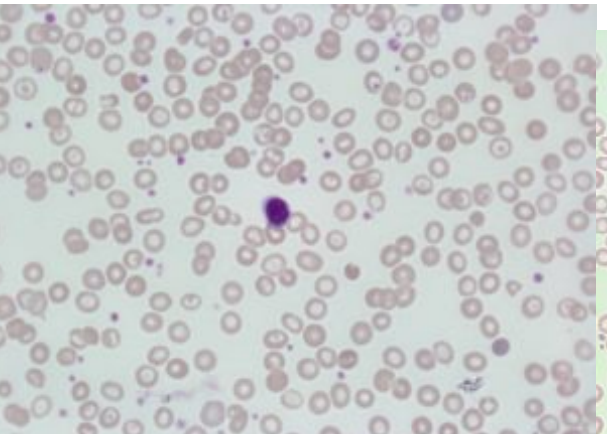

An image from a peripheral blood smear showing hypochromic, microcytic red blood cells with occasional targets which can beeen in IDA. 60x oil immersion. From MLS Collection, University of Alberta, https://doi.org/10.7939/R39883 33G
An image from a peripheral blood smear showing hypochromic, microcytic red blood cells. 50x oil immersion. From MLS Collection, University of Alberta, https://doi.org/10.7939/R3KS6J $\mathrm{K} 8 \mathrm{~F}$

\section{Cause(s): ${ }^{1,2}$}

Chronic Blood Loss (heavy menstruation, intermittent GI bleeding, etc.)

Increased Need (periods of rapid growth, pregnancy)

Inadequate intake (diet)

Impaired absorption (malabsorption)

Notes: When there is not enough iron to meet the requirements of the body, iron stores begin to deplete, and IDA occurs. Development of IDA occurs over a period of time. ${ }^{1-4}$ 


\title{
IDA development is said to occur in three stages: ${ }^{3}$
}

\begin{tabular}{|c|c|c|}
\hline $\begin{array}{l}\text { Stage } 1 \\
\text { (Storage Iron Depletion): } \\
\text { - Normal RBC maturation } \\
\text { - Decline in storage iron (decreased ferritin, } \\
\text { decreased iron stores in the bone marrow) } \\
\text { - No other evidence of anemia development. }\end{array}$ & $\begin{array}{l}\text { Stage } 2 \\
\text { (Transport Iron Depletion): } \\
\text { - Decreased serum iron and ferritin } \\
\text { - Transferrin and TIBC levels increase } \\
\text { - Absent iron stores in the bone marrow } \\
\text { - Evidence of anemia is not as apparent. }\end{array}$ & $\begin{array}{l}\text { Stage } 3 \\
\text { (Functional Iron Depletion- IDA): } \\
\text { - Anemia is evident } \\
\text { - PBS shows microcytic, hypochromic RBCs } \\
\text { - RBC development is affected } \\
\text { - Same iron study results as stage } 2 \\
\text { - Hb is decreased } \\
\text { - Hepcidin is decreased } \\
\text { - Erythropoietin is increased }\end{array}$ \\
\hline
\end{tabular}

\section{Laboratory Features of Iron Deficiency Anemia (At Stage 3): ${ }^{1-4}$}

\author{
CBC: \\ RBC Count: Decreased \\ PLT: Variable (increased in chronic bleeding) \\ $\mathrm{Hb}$ : Decreased \\ Hct: Decreased \\ MCV, MCH, MCHC: Decreased \\ RDW: Increased \\ Iron Studies: \\ Serum Iron: Decreased \\ Ferritin: Decreased \\ Transferrin: Increased \\ Transferrin Saturation: Decreased \\ TIBC: Increased
}

PBS:

Microcytic, hypochromic RBCs

Target cells

Elliptocytes

Teardrop cells

Normal WBC morphology

Other Tests:

Prussian Blue stain of the BM shows absent or

decreased iron

Reticulocyte count decreased

\section{References:}

1. McKenzie SB. Anemias of disordered iron metabolism and heme synthesis. In: Clinical laboratory hematology. 3rd ed. New Jersey: Pearson; 2015. p. 198-230.

2. Miller JL. Iron deficiency anemia: A common and curable disease. Cold Spring Harb Perspect Med [Internet]. 2013 Jul 1 [cited 2018 Jun 28];3(7):10.1101/cshperspect.a011866 a011866. Available from: http://www.ncbi.nlm.nih.gov/pmc/articles/PMC3685880/

3. Doig K. Disorders of iron kinetics and heme metabolism. In: Rodak's hematology clinical applications and principles. 5th ed. St. Louis, Missouri: Saunders; 2015. p. 297-313.

4. Finnegan K. Iron metabolism and hypochromic anemias. In: Clinical hematology and fundamentals of hemostasis. 5th ed. Philadelphia: F.A. Davis Company; 2009. p. 117-37. 


\section{1}

\section{Anemia of Chronic Inflammation/Disease (ACI/ACD)}

MICHELLE TO AND VALENTIN VILLATORO

\section{Cause(s):}

Anemia that occurs in patients with conditions that result in chronic inflammatory states such as rheumatoid arthritis, infections, and malignancies. Anemia is reversed when underlying condition is treated and inflammation subsides. ${ }^{1}$ Chronic inflammation leads to an increase in inflammatory cytokines and actue phase reactants that alter iron metabolism and decrease RBC production and lifespan.

\section{Additional notes:}

Acute phase reactants are serum proteins whose levels are increased by the liver in response to inflammation. Three related acute phase reactants to ACI are: ${ }^{2}$

1. Hepcidin

2. Lactoferrin

3. Ferritin

\section{Mechanisms of anemia development in ACI: ${ }^{1,3}$}

1. Decrease in iron available for erythropoiesis (increased hepcidin causes inhibition of iron release from macrophages and decreased iron absorption from the diet, iron bound to lactoferrin and ferritin is not available to developing RBCs)

2. EPO production in the kidneys is inhibited by cytokines 
3. Erythropoiesis is inhibited by cytokines (diminishes developing erythroid precursor's response to EPO)

4. Decreased RBC survival (increased activation of macrophages by inflammatory cytokines leads to increased removal of RBCs from circulation and decreased survival)

\section{Laboratory Features: ${ }^{1,2,4}$}

\begin{tabular}{|c|c|c|}
\hline $\begin{array}{l}\text { CBC: } \\
\text { RBC: Decreased } \\
\text { WBC: Normal or Increased depending on the cause of } \\
\text { the inflammation } \\
\text { PLT: Normal } \\
\text { Hb: Decreased } \\
\text { Hct: Normal to Decreased } \\
\text { MCV, MCH, MCHC: Normal to Decreased } \\
\text { RDW: Increased }\end{array}$ & $\begin{array}{l}\text { PBS: } \\
\text { Normochromic, Normocytic OR Microcytic, } \\
\text { hypochromic RBCs }\end{array}$ & $\begin{array}{l}\text { BM: } \\
\text { M:E Ratio: Increased } \\
\text { (Decreased production of erythroids, }+/ \text { - increased } \\
\text { production of myeloids) } \\
\text { Iron Stores: Increased }\end{array}$ \\
\hline $\begin{array}{l}\text { Iron Studies: } \\
\text { Serum Iron: Decreased } \\
\text { Ferritin: Increased } \\
\text { Transferrin: Decreased } \\
\text { Transferrin saturation: Normal to Decreased } \\
\text { TIBC: Decreased }\end{array}$ & $\begin{array}{l}\text { Other Tests: } \\
\text { N/A }\end{array}$ & \\
\hline
\end{tabular}

\section{References:}

1. McKenzie SB. Anemias of disordered iron metabolism and heme synthesis. In: Clinical laboratory hematology. 3rd ed. New Jersey: Pearson; 2015. p. 198-230.

2. Doig K. Disorders of iron kinetics and heme metabolism. In: Rodak's hematology clinical applications and principles. 5th ed. St. Louis, Missouri: Saunders; 2015. p. 297-313.

3. Turgeon ML. Hypochromic anemias and disorders of iron metabolism. In: Clinical hematology: theory and procedures. 4th ed. Philadelphia, PA: Lippincott Williams \& Wilkins; 1999. p. 131-144.

4. Finnegan K. Iron metabolism and hypochromic anemias. In: Clinical hematology and fundamentals of hemostasis. 5th ed. Philadelphia: F.A. Davis Company; 2009. p. 117-37. 


\section{2}

Sideroblastic Anemia

\section{MICHELLE TO AND VALENTIN VILLATORO}

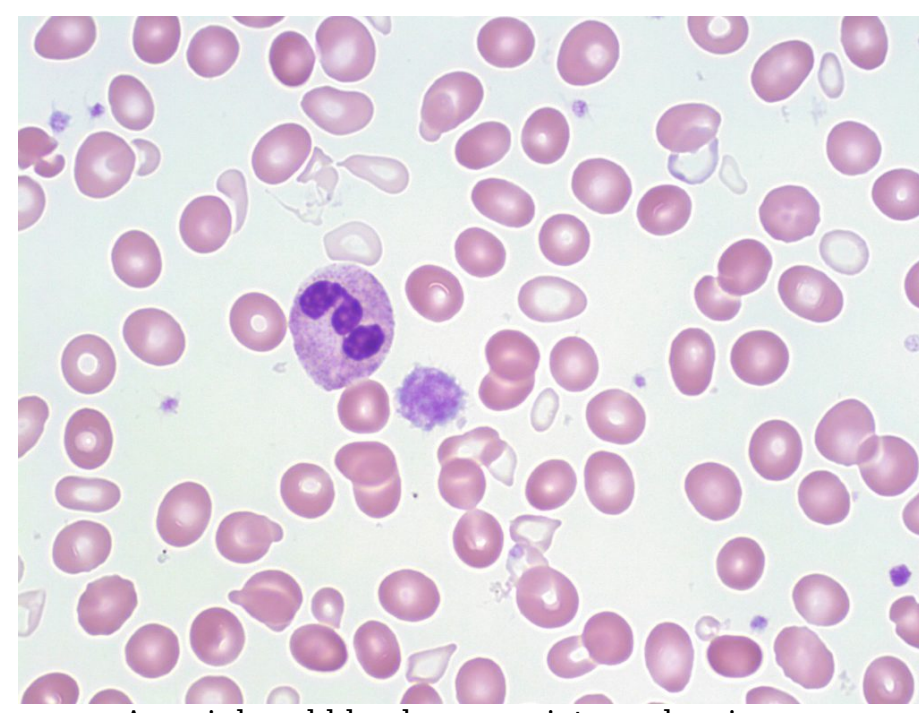

A peripheral blood smear picture showing a dimorphic population of red blood cells: hypochromic, microcytic and normochromic, normocytic red cells. Dimorphissm is commonly seen in Sideroblastic Anemia cases. 50x oil immersion. From MLS Collection, University of Alberta, https://doi.org/10.7939/R3P844B3X

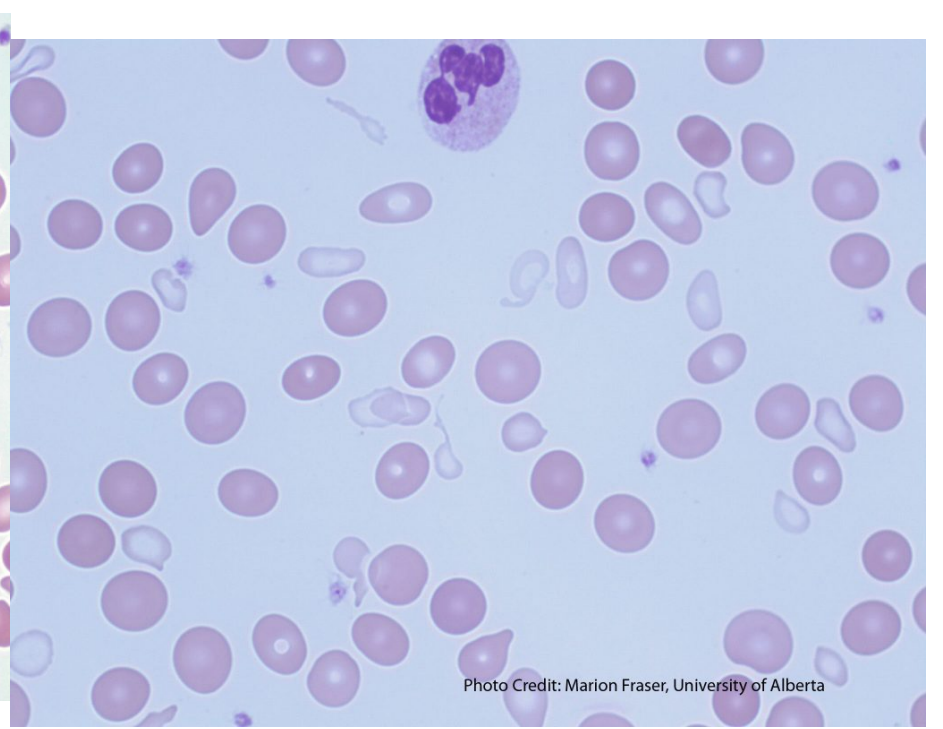

A peripheral blood smear picture showing a dimorphic RBC population and tear cells in sideroblastic anemia. From MLS Collection, University of Alberta, https://doi.org/10.7939/R3CF9JN85

Cause(s): Development of sideroblastic anemia can be due to hereditary or acquired causes that lead to abnormal heme synthesis. ${ }^{1,2}$

Hereditary: Sex-linked or autosomal recessive mutations

Acquired: Idiopathic, MDS and other malignancies, drugs, lead toxicity 
CBC:

RBC: Decreased

WBC: Variable

PLT: Variable

Hb: Decreased

MCV, MCH, MCHC: Normal to Decreased (as they are

averages of the RBC appearance)

RDW: Increased

RETIC: Decreased

Iron Studies:

Serum Iron: Increased

Ferritin: Increased

Transferrin: Normal to Decreased

Transferrin Saturation: Increased

TIBC: Normal to Decreased
PBS:

Dimorphic population (Normochromic/Normocytic

alongside Hypochromic/Microcytic )

Tears

Schistocytes

Pappenheimer bodies

Basophilic stippling

Other Tests:

Bilirubin: Increased

Haptoglobin: Decreased

LD: Increased

Prussian blue stain of BM shows increased iron

levels and ringed sideroblasts

\section{References:}

1. McKenzie SB. Anemias of disordered iron metabolism and heme synthesis. In: Clinical laboratory hematology. 3rd ed. New Jersey: Pearson; 2015. p. 198-230.

2. Doig K. Disorders of iron kinetics and heme metabolism. In: Rodak's hematology clinical applications and principles. 5th ed. St. Louis, Missouri: Saunders; 2015. p. 297-313.

3. Finnegan K. Iron metabolism and hypochromic anemias. In: Clinical hematology and fundamentals of hemostasis. 5th ed. Philadelphia: F.A. Davis Company; 2009. p. 117-37. 


\section{3}

\section{Thalassemia}

\section{MICHELLE TO AND VALENTIN VILLATORO}

An interactive or media element has been excluded from this version of the text. You can view it online here: https://pressbooks.library.ualberta.ca/mlsci/?p=386

Images show thalassemia peripheral blood smears with hypochromic, microcytic red blood cells and poikilocytosis. From MLS Collection, University of Alberta.

Image 1: 50x oil immersion. https://doi.org/10.7939/R3DR2PQ4J

Image 2: 50x oil immersion. https://doi.org/10.7939/R3V698T05

Image 3: 50x oil immersion. https://doi.org/10.7939/R3HD7P773

Thalassemias are classified as a group of genetic hemoglobin disorders where the production of $\alpha$ and $\beta$ globin chains is affected. This is considered to be a quantitative hemoglobin disorder and is categorized by the affected globin chain (alpha or beta), and as major or minor depending on the severity of the disease. $^{1,2}$

\section{Alpha-Thalassemia:}

\section{Cause(s):}

$\alpha$ globin chain genes are located on chromosome 16 and there are normally four genes in total $(\alpha \alpha / \alpha \alpha)$, two inherited from each parent. $\alpha$-thalassemia results when there is a deletion in any number of the $\alpha$ globin gene. The severity of anemia and amount of $\alpha$ globin chain production is dependent the number of genes that are deleted. ${ }^{3}$ 


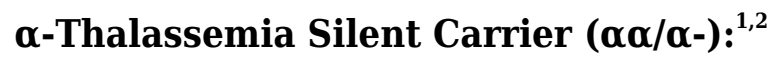

Occurs when one $\alpha$ gene is deleted. There is still adequate production of $\alpha$ to ensure normal hemoglobin synthesis. Patient is asymptomatic and the mutation is benign.

In newborns, there is an excess production of $\gamma$ globin chains. These $\gamma$ globin chains tend to also form tetramers and result in Hemoglobin Barts (Hb Barts). Hb Barts has a high oxygen affinity and is inefficient for oxygen delivery to the tissues of the developing fetus. In the silent carrier state, there is only a small amount of $\mathrm{Hb}$ Barts produced.

\section{$\alpha-T h a l a s s e m i a ~ M i n o r(\alpha \alpha /-)$ or $(\alpha-/ \alpha-):^{1,2}$}

Occurs when two $\alpha$ genes are deleted. There is now a 50\% reduction in normal $\alpha$ globin chain production.

In adults, increased production of red blood cells is able to compensate for the decrease in $\alpha$ chain production, and $\alpha$ and $\beta$ globin chain production is balanced. Patients are asymptomatic and any anemia present is mild.

There is between 5-15\% hemoglobin Barts present at birth, but this decreases once $\beta$ globin chain production takes over and $\gamma$ globin chain production decreases. In adults, globin chain production is balances, so no Hemoglobin $\mathrm{H}$ is formed.

\section{Hemoglobin H Disease ( $\alpha-/-):^{1,2}$}




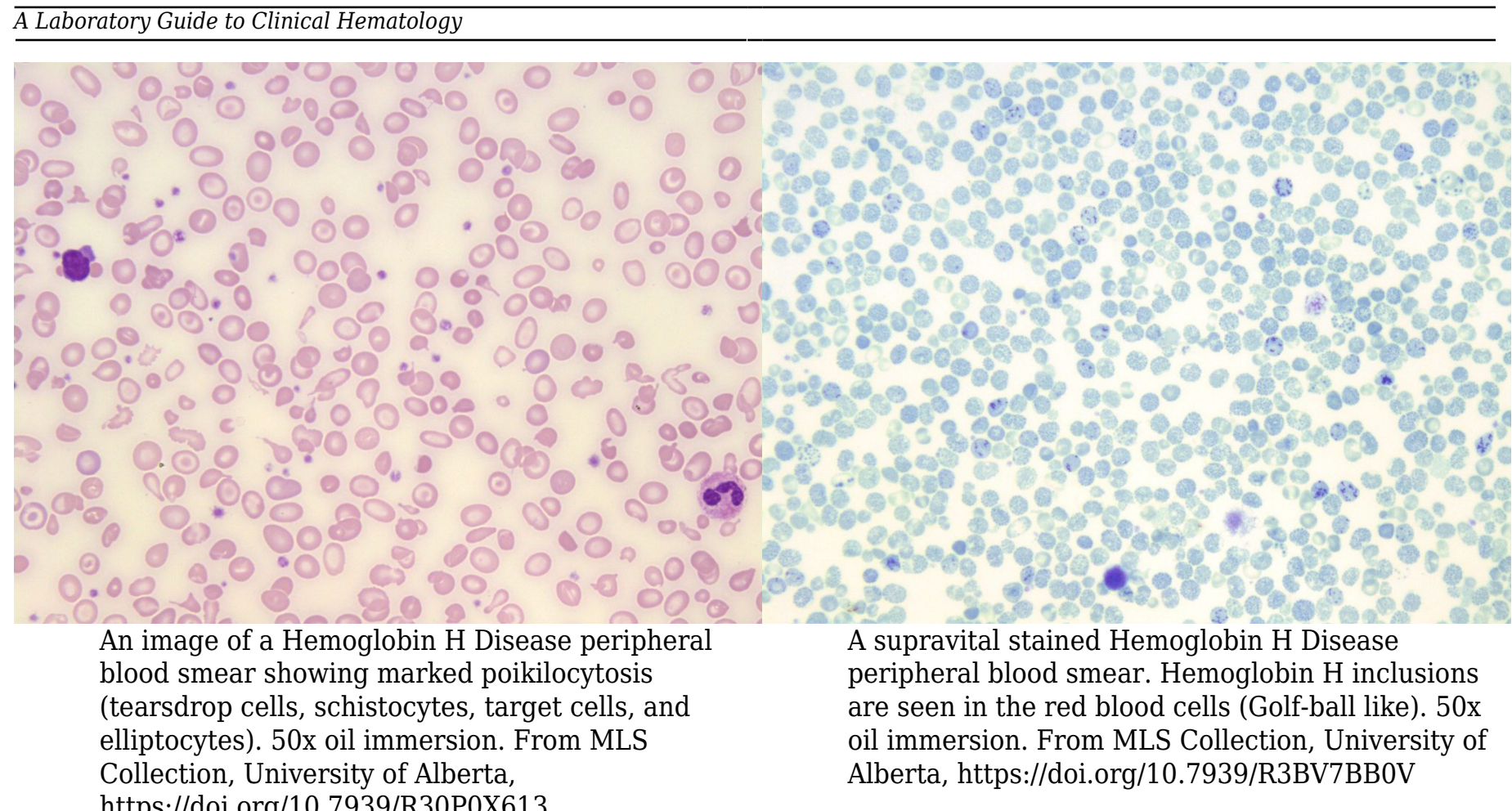

Occurs when three $\alpha$ genes are deleted. $\alpha$ gene production is significantly reduced (75\% reduction) causing a higher imbalance between the number of $\alpha$ and $\beta$ globin chains being produced. Patients present with a chronic hemolytic anemia that varies from mild to moderate. Patients are transfusionindependent.

The excess $\beta$ globin chains form tetramers known as Hemoglobin $\mathrm{H}(\mathrm{Hb} \mathrm{H}) . \mathrm{Hb} \mathrm{H}$ is unstable and often precipitates within red blood cells resulting in hemolytic anemia. Production of Hb Barts at birth is increased.

\section{Hydrops Fetalis/ a-Thalassemia Major (-/-): ${ }^{1}$}

Occurs when all four $\alpha$ genes are deleted (no $\alpha$ globin chain production).

Because no sustainable amount of $\alpha$ globin chains is produced, this state is usually considered to be incompatible with life. Excess $\gamma$ globin chains result in the formation of $\mathrm{Hb}$ Barts. Due to its high affinity for oxygen, it is not able to efficiently transport oxygen to the tissues of the developing fetus. The marked tissue hypoxia usually results in fetal death in utero or shortly after birth. 
Table 1. Laboratory Findings of $\alpha-$ Thalassemias $^{1}$

\begin{tabular}{|c|c|c|c|c|}
\hline$\alpha$-Thalassemia State & CBC and RETIC & PBS & $\mathbf{B M}$ & Hemoglobin Content \\
\hline $\begin{array}{l}\alpha \text {-Thalassemia Silent } \\
\text { Carrier }(\alpha \alpha / \alpha-)\end{array}$ & $\begin{array}{l}\text { Hb: Normal } \\
\text { RBC: Normal } \\
\text { MCV/MCH/MCHC: Normal } \\
\text { RDW: Normal } \\
\text { RETIC: Normal }\end{array}$ & $\begin{array}{l}\text { - Asymptomatic } \\
\text { - Normocytic RBCs }\end{array}$ & Normal & $\begin{array}{l}\text { Hb A: Normal } \\
\text { Hb Barts: } 1-3 \% \text { at birth } \\
\text { Hb H: } 0 \%\end{array}$ \\
\hline $\begin{array}{l}\alpha-T h a l a s s e m i a ~ M i n o r \\
(\alpha \alpha /-) \text { or }(\alpha-/ \alpha-)\end{array}$ & $\begin{array}{l}\text { Hb: Normal to Decreased } \\
\text { RBC: Normal to Increased } \\
\text { MCV/MCH/MCHC: Decreased } \\
\text { RDW: Normal } \\
\text { RETIC: Elevated }\end{array}$ & $\begin{array}{l}\text { - Mild asymptomatic anemia } \\
\text { - Hypochromic, microcytic RBCs } \\
\text { - Poikilocytosis: mainly targets } \\
\text { - Basophilic Stippling }\end{array}$ & Erythroid Hyperplasia & $\begin{array}{l}\text { Hb A: Slight decrease } \\
\text { Hb Barts: } 5-15 \% \text { at birth } \\
\text { Hb H: } 0 \%\end{array}$ \\
\hline $\begin{array}{l}\text { Hemoglobin H Disease } \\
(\alpha-/-)\end{array}$ & $\begin{array}{l}\text { Hb: Decreased } \\
\text { RBC: Increased } \\
\text { MCV/MCH/MCHC: Decreased } \\
\text { RDW: Normal to Increased } \\
\text { RETIC: Elevated }\end{array}$ & $\begin{array}{l}\text { - Mild to moderate anemia } \\
\text { - Hypochromic, microcytic RBCs } \\
\text { - Poikilocytosis: targets, tears, } \\
\text { ellipto, schisto, sphero, etc. } \\
\text { - Polychromasia } \\
\text { - Basophilic Stippling } \\
\text { - Howell-Jolly Bodies } \\
\text { - Pappenheimer Bodies } \\
\text { - nRBCs } \\
\text { - Heinz Bodies and Hb H } \\
\text { inclusions (Supravital Stain) }\end{array}$ & Erythroid Hyperplasia & $\begin{array}{l}\text { Hb A: Decreased } \\
\text { Hb Barts: } 10-40 \% \text { at birth, } \\
\text { traces in adults } \\
\text { Hb H: } 1-40 \% \text { in adults }\end{array}$ \\
\hline 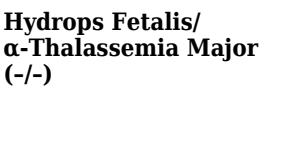 & $\begin{array}{l}\text { Hb: Decreased } \\
\text { RBC: Decreased } \\
\text { MCV/MCH/MCHC: Decreased } \\
\text { RDW: Increased } \\
\text { RETIC: Elevated }\end{array}$ & $\begin{array}{l}\text { - Severe anemia } \\
\text { - Hypochromic, microcytic RBCs }\end{array}$ & Erythroid Hyperplasia & 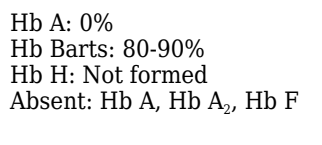 \\
\hline
\end{tabular}

\section{Beta-Thalassemias}

\section{Cause(s):}

$\beta$ globin chain genes are located on chromosome 11 and there are normally two genes in total $(\beta / \beta)$ one inherited from each parent. $\beta$-thalassemia is usually due to point mutations in the $\beta$ globin genes. These point mutations cause production of $\beta$ globin chains to be reduced $\left(\beta^{+}\right)$or abolished completely $\left(\beta^{0}\right)$. $^{3}$

\section{$\beta$-Thalassemia Silent Carrier $\left(\beta^{\text {Silent }} / \beta\right):^{2}$}

$\beta$ globin chain genes mutation does not result in any abnormal hematological findings and $\beta$ globin chain production is normal or nearly normal.

\section{$\beta$-Thalassemia Minor $\left(\beta^{0} / \beta\right.$ or $\left.\beta^{+} / \beta\right):^{1,2}$}


One $\beta$ globin chain gene is mutated while the other $\beta$ globin chain gene is normal. Patient is able to sufficiently produce enough $\beta$ globin chains to maintain normal oxygenation and red blood cell lifespan.

Patients are asymptomatic and have mild anemia that can worsen under conditions of stress.

\section{$\boldsymbol{\beta}$-Thalassemia Intermedia $\left(\boldsymbol{\beta}^{+} / \boldsymbol{\beta}^{\text {Silent }}\right.$ or $\boldsymbol{\beta}^{0} / \boldsymbol{\beta}^{\text {Silent }}$ or $\left.\boldsymbol{\beta}^{\text {Silent }} / \boldsymbol{\beta}^{\text {Silent }}\right):^{2}$}

Mutations in the $\beta$ genes result in reduced $\beta$ globin chain production. Clinical symptoms are variable, and more severe than $\beta$-Thalassemia Minor, though patients do not require transfusions to survive.

\section{$\beta$-Thalassemia Major $\left(\beta^{+} / \beta^{+}\right.$or $\beta^{+} / \beta^{0}$ or $\left.\beta^{0} / \beta^{0}\right):^{1,2}$}

Mutations to both $\beta$ genes results in severely decreased or absent production of $\beta$ globin chains. Excess $\alpha$ globin chains are unable to form tetramers leading to their precipitation and accumulation in the red blood cell. This damages the cell and results in a chronic and severe hemolytic anemia.

Patients require regular transfusions.

\section{Table 2. Laboratory Findings of $\beta$-Thalassemias ${ }^{2}$}




\begin{tabular}{|c|c|c|c|c|}
\hline$\beta$-Thalassemia State & CBC and RETIC & PBS & $\mathbf{B M}$ & Hemoglobin Content \\
\hline $\begin{array}{l}\beta \text {-Thalassemia Silent Carrier } \\
\left(\beta^{\text {Silent }} / \beta\right)\end{array}$ & $\begin{array}{l}\text { Hb: Normal } \\
\text { RBC: Normal } \\
\text { MCV/MCH/MCHC: Normal } \\
\text { RDW: Normal } \\
\text { RETIC: Normal }\end{array}$ & N/A & N/A & $\begin{array}{l}\text { Hb A: Normal } \\
\mathrm{Hb} \mathrm{A}_{2}: \text { Normal } \\
\mathrm{Hb} \mathrm{F}: \text { Normal }\end{array}$ \\
\hline
\end{tabular}

\begin{tabular}{|c|c|c|c|c|}
\hline $\begin{array}{l}\beta \text {-Thalassemia Minor } \\
(\beta / \beta \\
\left.\text { or } \beta^{+} / \beta\right)\end{array}$ & $\begin{array}{l}\text { Hb: Decreased } \\
\text { RBC: Normal to Increased } \\
\text { MCV/MCH/MCHC: Decreased } \\
\text { RDW: Normal } \\
\text { RETIC: Normal to Increased }\end{array}$ & $\begin{array}{l}\text { - Hypochromic, microcytic RBCs } \\
\text { - Poikilocytosis: mainly targets } \\
\text { - Basophilic stippling }\end{array}$ & Erythroid Hyperplasia & $\begin{array}{l}\text { Hb A: } 92-95 \% \\
\mathrm{Hb} \mathrm{A}_{2}: 3.5-7.0 \% \\
\text { Hb F: } 1-5 \%\end{array}$ \\
\hline
\end{tabular}

\begin{tabular}{|c|c|c|c|c|}
\hline $\begin{array}{l}\beta \text {-Thalassemia Intermedia } \\
\left(\beta^{+} / \beta^{\text {Silent }}\right. \\
\text { or } \beta^{0} / \beta^{\text {Silent }} \\
\left.\text { or } \beta^{\text {Silent }} / \beta^{\text {Silent }}\right)\end{array}$ & $\begin{array}{l}\text { Hb: Decreased } \\
\text { RBC: Increased } \\
\text { MCV/MCH/MCHC: Decreased } \\
\text { RDW: Normal } \\
\text { RETIC: Increased }\end{array}$ & $\begin{array}{l}\text { - Hypochromic, microcytic RBCs } \\
\text { - Variable poikilocytosis and } \\
\text { anisocytosis depending on the } \\
\text { genetic mutation. } \\
\text { - Polychromasia } \\
\text { - Basophilic stippling }\end{array}$ & Erythroid Hyperplasia & $\begin{array}{l}\mathrm{Hb} A: \text { Decreased } \\
\mathrm{Hb} \mathrm{A}_{2} \text { : Increased } \\
\mathrm{Hb} \mathrm{F} \text { : Increased }\end{array}$ \\
\hline & $\begin{array}{l}\text { Hb: Decreased } \\
\text { RBC: Increased } \\
\text { MCV/MCH/MCHC: Decreased } \\
\text { RDW: Normal to Increased } \\
\text { RETIC: Increased }\end{array}$ & $\begin{array}{l}\text { - Hypochromic, microcytic RBCs } \\
\text { - Poikilocytosis: targets, tears, } \\
\text { ellipto, schisto, sphero, etc. } \\
\text { - Polychromasia } \\
\text { - Basophilic Stippling } \\
\text { - Howell-Jolly Bodies } \\
\text { - Pappenheimer Bodies } \\
\text { - nRBCs } \\
\text { - Heinz Bodies (supravital stain) }\end{array}$ & $\begin{array}{l}\text { Erythroid Hyperplasia } \\
\text { (Ineffective erythropoiesis) }\end{array}$ & $\begin{array}{l}\text { Hb A: Absent or decreased } \\
\text { Hb A } A_{2} \text { Variable } \\
\text { Hb F: } 70-90 \%\end{array}$ \\
\hline
\end{tabular}

$\beta$-Thalassemia Major

$\left(\beta^{+} / \beta^{+}\right.$

or $\beta^{+} / \beta^{0}$

or $\beta^{0} / \beta^{0}$ )

\section{Other Laboratory Tests to Assess Thalassemia: ${ }^{2}$}

Iron Studies (Thalassemia Iron Studies are shown in the next chapter)

Hemoglobin Electrophoresis

High Performance Liquid Chromatography (HPLC)

Molecular testing for genetic mutations/deletions 


\section{Notes:}

Above results are only typical findings, which may be altered depending on individual variation, treatment give (such as RBC transfusions), and genetic sub-type.

The peripheral blood smear picture for the minor forms of Thalassemia look very similar to that of Iron Deficiency Anemia. The difference between the two conditions can be distinguished by comparing iron study results, as well as specific CBC findings (RDW, RBC count), and peripheral smear findings (inclusions, poikilocytosis). ${ }^{2}$

\section{References:}

1. Randolph TR. Thalassemia. In: Clinical laboratory hematology. 3rd ed. New Jersey: Pearson; 2015. p. 251-276.

2. Keohane EM. Thalassemias. In: Rodak's hematology clinical applications and principles. 5th ed. St. Louis, Missouri: Saunders; 2015. p. 454-74.

3. Chonat S, Quinn CT. Current standards of care and long term outcomes for thalassemia and sickle cell disease. Adv Exp Med Biol [Internet]. 2017 [cited 2018 Jun 5];1013:59-87. Available from: http://www.ncbi.nlm.nih.gov/pmc/articles/PMC5720159/ 


\section{4}

\section{Iron Studies}

\section{MICHELLE TO AND VALENTIN VILLATORO}

An interactive or media element has been excluded from this version of the text. You can view it online here:

https://pressbooks.library.ualberta.ca/mlsci/?p=400

Images of iron stained bone marrow particle smears showing various amounts of iron stores (indicated by the amount of blue present). Perls Prussian Blue. From MLS Collection, University of Alberta.

Image 1: 10x magnification. Low iron stores. https://doi.org/10.7939/R3NC5ST92 Image 2: 10x magnification. Normal iron stores. https://doi.org/10.7939/R3XP6VK0C Image 3: 10x magnification. High iron stores. https://doi.org/10.7939/R3ZP3WG13

Table 1. Iron studies of hypochromic and microcytic anemias. ${ }^{1-3}$

\begin{tabular}{ccccccc}
\hline Anemia & Serum Iron & Ferritin & Transferrin & $\begin{array}{c}\text { Transferrin } \\
\text { Saturation }\end{array}$ & TIBC & BM Iron stores \\
\hline IDA & D & D & I & D & I & Absent/D \\
\hline $\begin{array}{c}\text { Anemia of Chronic } \\
\text { Inflammation }\end{array}$ & N/I & N/I & N/I & N/I & N/I & I \\
\hline Sideroblastic Anemia & I & I & I & N/D & I & N/D \\
\hline
\end{tabular}

$\mathrm{N}=$ Normal $\mathrm{I}=$ Increased $\mathrm{D}=$ Decreased 


\section{References:}

1. McKenzie SB. Anemias of disordered iron metabolism and heme synthesis. In: Clinical laboratory hematology. 3rd ed. New Jersey: Pearson; 2015. p. 198-230.

2. Doig K. Disorders of iron kinetics and heme metabolism. In: Rodak's hematology clinical applications and principles. 5th ed. St. Louis, Missouri: Saunders; 2015. p. 297-313.

3. Finnegan K. Iron metabolism and hypochromic anemias. In: Clinical hematology and fundamentals of hemostasis. 5th ed. Philadelphia: F.A. Davis Company; 2009. p. 117-37. 


\section{$\mathrm{V}$ \\ RED BLOOD CELLS: DNA METABOLISM ABNORMALITIES \& BONE MARROW FAILURE}




\section{5 \\ Megaloblastic Anemia}

\section{MICHELLE TO AND VALENTIN VILLATORO}

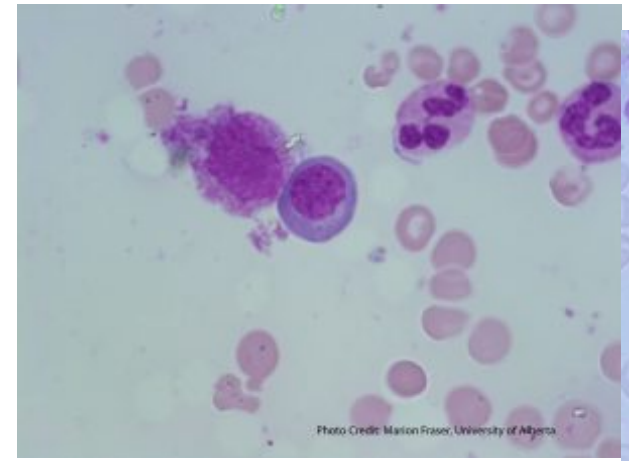

An image of a megaloblastic bone marrow showing nuclear-cytoplasmic asynchrony in a polychromatic normoblast. From MLS Collection, University of Alberta, https://doi.org/10.7939/R3Q815 $76 \mathrm{M}$

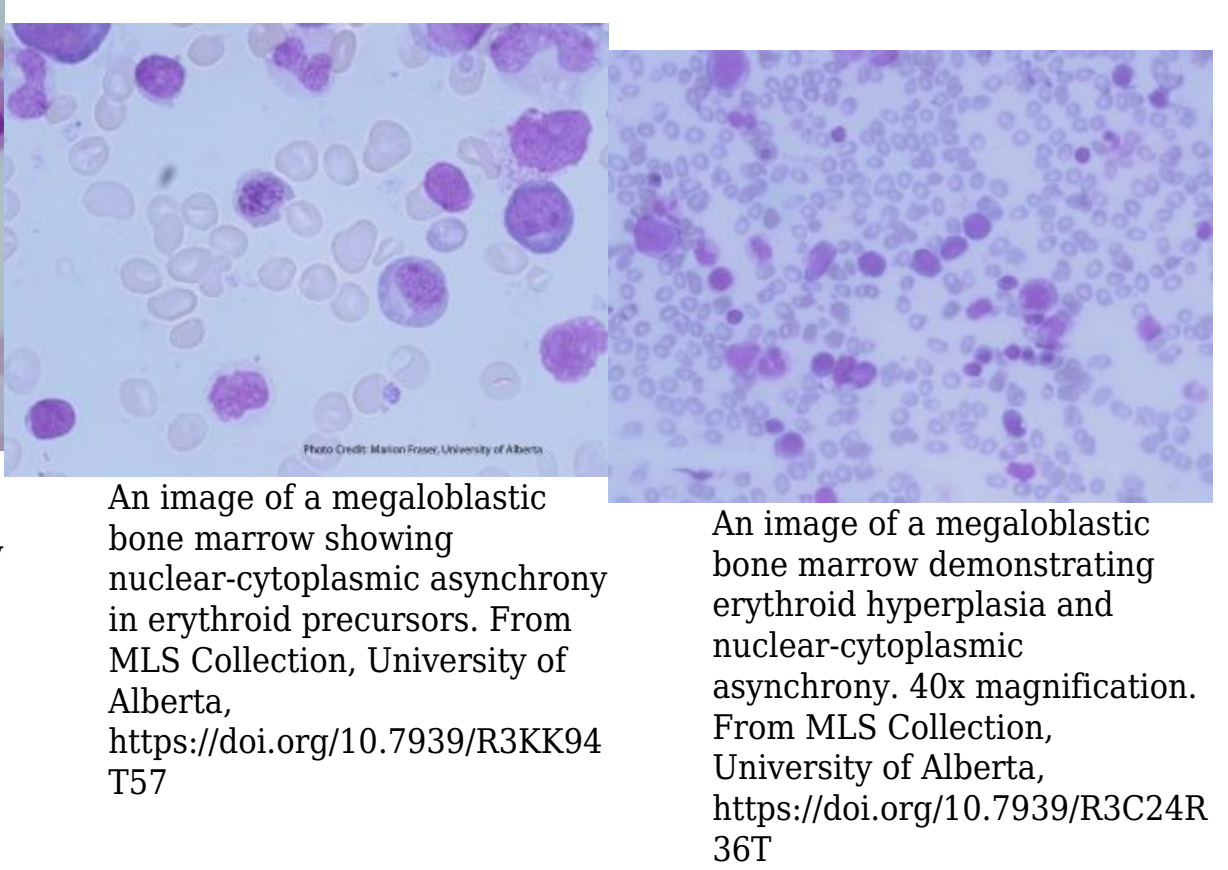

An image of a megaloblastic bone marrow showing asynchrony in erythroid precursors. From MLS Collection, University of https://doi.org/10.7939/R3KK94 T57
An image of a megaloblastic bone marrow demonstrating erythroid hyperplasia and nuclear-cytoplasmic asynchrony. 40x magnification. From MLS Collection, University of Alberta, 36T

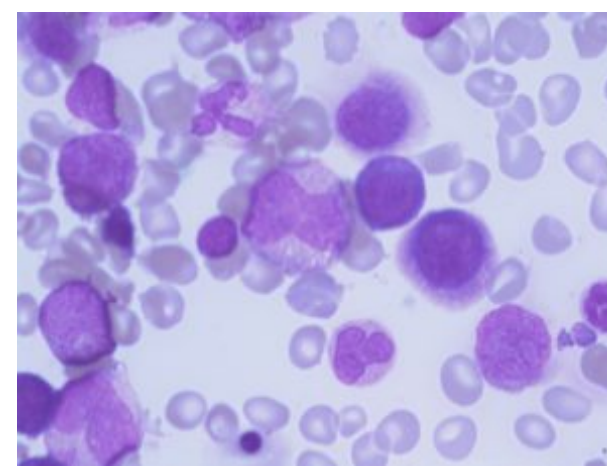

An image of a megaloblastic bone marrow demonstrating a giant metamyelocyte. From MLS Collection, University of Alberta, https://doi.org/10.7939/R33J39 G7T
An image of a megaloblastic bone marrow showing a hypersegmented neutorphil and a giant band. From MLS Collection, University of Alberta, https://doi.org/10.7939/R37941 $91 \mathrm{~K}$ 


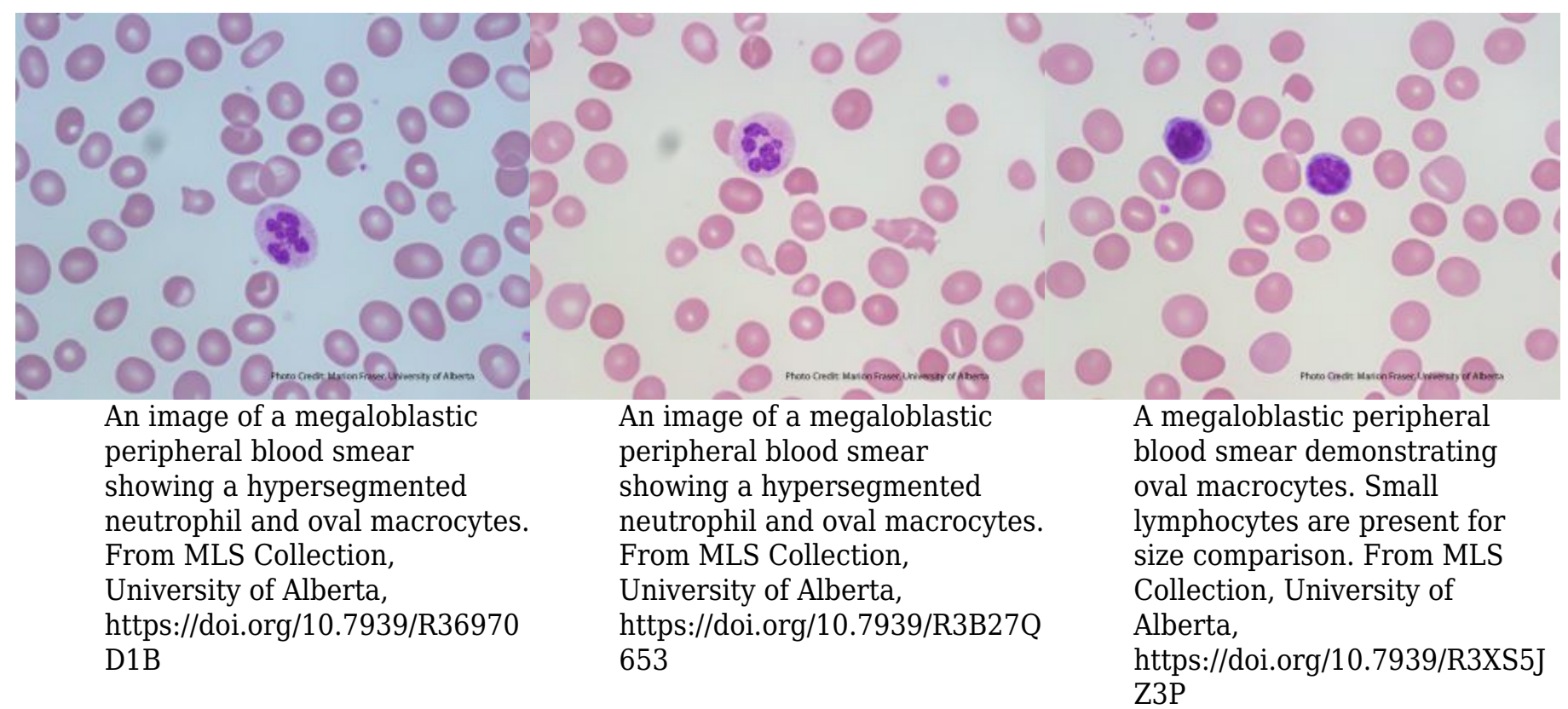

\section{Cause(s):}

Megaloblastic anemia occurs when there are defects in DNA synthesis that cause problems with blood cell production and maturation (all cells are affected, not just red blood cells). Megaloblastic anemia is most commonly caused by deficiencies in Vitamin $\mathrm{B}_{12}$ (cobalamin) and folate (folic acid). Both Vitamin $\mathrm{B}_{12}$ and folate are important factors used in the process of DNA synthesis. ${ }^{1}$

\section{Cellular characteristics of Megaloblastic Anemia:}

1. A characteristic finding in bone marrow smears for megaloblastic anemia would the appearance of nuclear-cytoplasmic (N:C) asynchrony in all cell lines. ${ }^{1} \mathrm{~N}: \mathrm{C}$ asynchrony describes the inability of the cell's chromatin to mature normally giving the nucleus a more immature, more fine, looser, and larger appearance than expected compared to that of the cytoplasm. Cytoplasm maturation is not affected and matures normally. Due to these characteristics, the cells are described as megaloblastic. ${ }^{1,2}$

2. Another characteristic finding on the peripheral blood smear would be the appearance of hypersegmented neutrophils. Hypersegmentation is described when either observation is present: ${ }^{1,2}$

- $5 \%$ or more neutrophils have 5 lobes 
- One neutrophil with $\geq 6$ lobes

3. Oval macrocytes are also indicative of megaloblastic anemia. ${ }^{2}$

\section{Function of Folate and Vitamin $B_{12}$ in DNA synthesis:}

Folate is ingested as folic acid which is inactive. The process of converting folic acid to its active form (Tetrahydrofolate, THF) requires the help of Vitamin $\mathrm{B}_{12} \cdot{ }^{1}$ Vitamin $\mathrm{B}_{12}$ is used as a cofactor in a reaction that converts inactive folate (N5-methylTHF) into the active Tetrahydrofolate (THF) form which is then used to continue DNA synthesis. ${ }^{1,3}$ Without Vitamin $B_{12}$ or folate, the nucleotide thymidine cannot be produced and DNA synthesis is impaired. ${ }^{2}$

\section{Vitamin B12 (Cobalamin)}

\section{Absorption:}

Available in eggs, milk, and meat. The low $\mathrm{pH}$ in the stomach causes Vitamin $\mathrm{B}_{12}$ to be released from ingested proteins. Vitamin $B_{12}$ then binds to haptocorrin to be transported into the duodenum. In the duodenum, proteases release the Vitamin $B_{12}$ and then it is picked up by intrinsic factor where it transports it to enterocytes of the ileum to be absorbed. ${ }^{1}$

\section{Transport in circulation:}

Once absorbed by the gastrointestinal tract, the transport protein called transcobalamin binds the Vitamin $B_{12}$ to be transported to the rest of the body in circulation. ${ }^{1,2}$

\section{Vitamin $\mathbf{B}_{12}$ deficiency:}

Can occur to due to a variety of causes such as: malabsorption, bacterial and parasitic infection, 
inadequate intake in the diet, or impaired utilization by the body. ${ }^{1,2}$

Vitamin $B_{12}$ deficiency can develop secondary to the absence of intrinsic factor (IF) which is used to help absorb Vitamin $B_{12}$ into the body. IF deficiency can be caused by autoantibodies against IF and gastric cells resulting in a type of anemia called Pernicious anemia. ${ }^{1,3}$

\section{Folate (Folic acid)}

\section{Absorption:}

Folate can be found in yeast, milk, eggs, mushrooms, and leafy greens and is easily destroyed by heat. Folate is absorbed throughout the gastrointestinal tract as folic acid and converted into N5-methylTHF in the cells. ${ }^{1}$

\section{Folate deficiency:}

Causes of folate deficiency can be due to inadequate intake in the diet, malabsorption, drugs that interfere with use, and an increased need (such as during pregnancy or rapid growth). ${ }^{1,3}$

\section{Laboratory Features of Megaloblastic Anemia: ${ }^{1,3}$}

\begin{tabular}{lll}
\hline CBC: & PBS: & BM: \\
RBC, WBC, PLT, Hb, Hct: Decreased & *Ovalmacrocytes & M:E Ratio: decreased (Ineffective erythropoiesis) \\
*MCV: Usually > 110 fL & Howell-Jolly Bodies & Hypercellular \\
MCH: Increased & *Hypersegmented neutrophils & Enlarged precursors \\
MCHC: Normal & Schistocytes & Giant metamyelocytes and bands \\
RETIC: Normal to decreased & Teardrop Cells & \\
Other Tests: & & \\
Folate deficiency & & \\
- Serum Folate: Decreased & & \\
Vitamin $B_{12}$ deficiency & \\
- Serum Vitamin $\mathrm{B}_{12}:$ Decreased & \\
- IF blocking antibodies & \\
- Antibody assays (Pernicious anemia) & \\
* Indicates the characteristic morphological findings in megaloblastic anemia blood smears & \\
\hline
\end{tabular}




\section{References:}

1. Hubbard J, Robinson S. Megaloblastic and nonmegaloblastic macrocytic anemias. In: Clinical laboratory hematology. 3rd ed. New Jersey: Pearson; 2015. p. 277-301.

2. Goossen LH. Anemias caused by defects of DNA metabolism. In: Rodak's hematology clinical applications and principles. 5th ed. St. Louis, Missouri: Saunders; 2015. p. 314-30.

3. Nagao T, Hirokawa M. Diagnosis and treatment of macrocytic anemias in adults. J Gen Fam Med [Internet]. 2017 Oct 13 [cited 2018 Jun 25];18(5):200-4. Available from: http://doi.wiley.com/10.1002/jgf2.31 


\section{6}

\section{Non-Megaloblastic Macrocytic Anemia}

\section{MICHELLE TO AND VALENTIN VILLATORO}

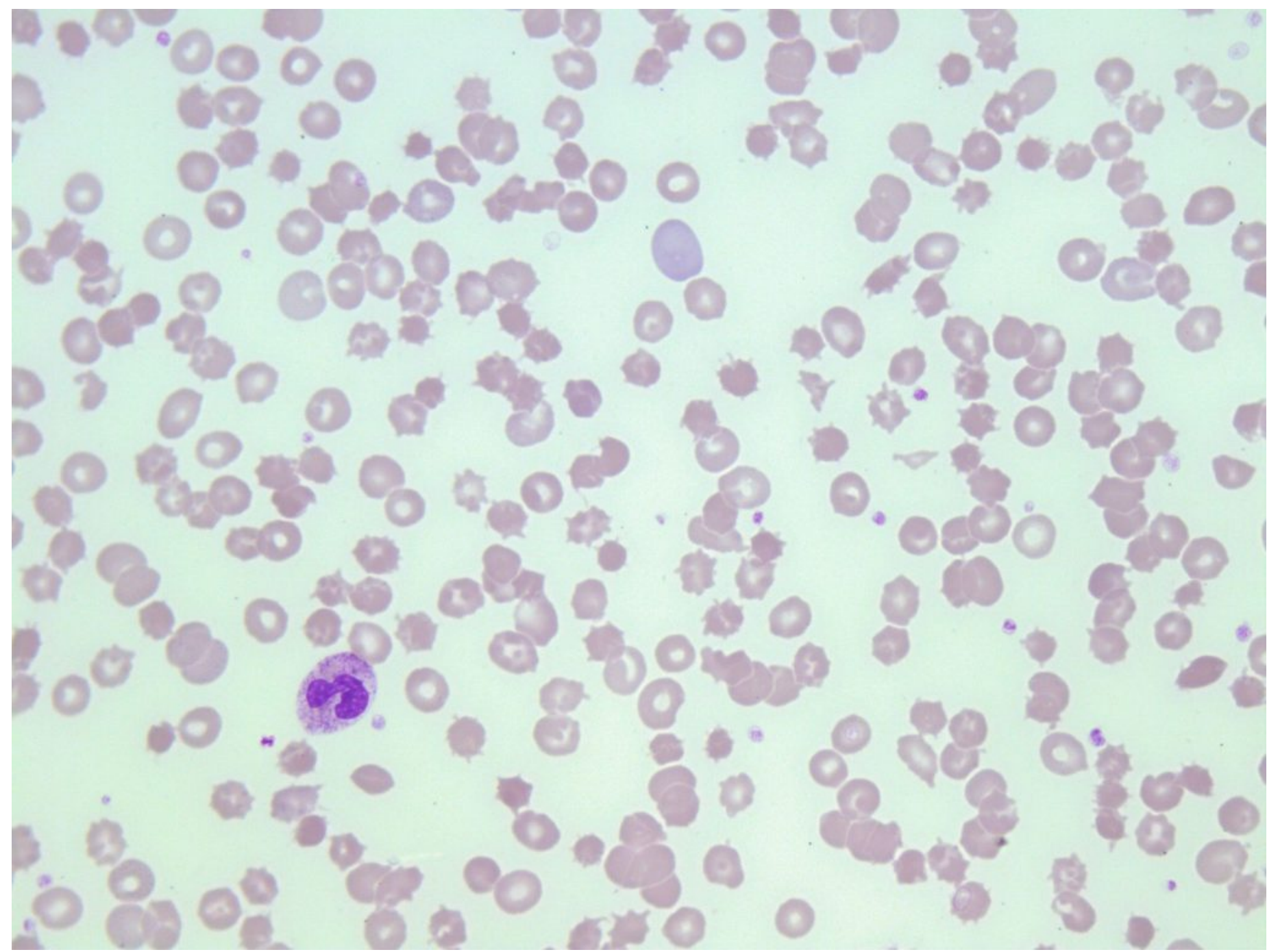

An image from a peripheral blood smear demonstrating round macrocytes and poikilocytosis in liver disease. 100x oil immersion. From MLS Collection, University of Alberta, https://doi.org/10.7939/R3MP4W32X

\section{Cause(s):}

A group of anemias that present with macrocytes without megaloblastic features. Most often, nonmegaloblastic macrocytic anemias are caused by: alcoholism, liver disease, bone marrow failure, and 
myelodysplastic syndromes (MDS). ${ }^{1,2}$

Chronic and heavy consumption of alcohol can lead to macrocytosis due to a variety of effects it has in erythrocyte development. Alcohol can not only interfere with folate metabolism but also is also directly toxic on bone marrow precursors. ${ }^{1,3}$

Liver disease is commonly associated with alcoholism and it is thought that macrocytosis is caused by an increase in cholesterol and lipids in the red blood cell membrane. ${ }^{3}$

Note: Additional information about bone marrow failure and MDS will be discussed in later chapters.

\section{Laboratory Features: ${ }^{1-4}$}

\section{CBC:}

PLT: Decreased

*MCV: usually 100-110 fL

(MCV is rarely $>110 \mathrm{fL}$ )

*RETIC: Increased (if hemolytic anemia is present)
PBS:

*Round Macrocytes

Target cells

*NO hypersegmented neutrophils
BM:

Nomorcellular or hypercellular

Erythroid hyperplasia

*Megaloblastic features are absent in precursors
Iron Studies (Liver Disease):

Serum Iron: Decreased to Normal

Ferritin: Increased

Transferrin: Normal

Transferrin Saturation: Normal to Increased
Other Tests:

Liver enzyme tests 


\section{References:}

1. Hubbard J, Robinson S. Megaloblastic and nonmegaloblastic macrocytic anemias. In: Clinical laboratory hematology. 3rd ed. New Jersey: Pearson; 2015. p. 277-301.

2. Nagao T, Hirokawa M. Diagnosis and treatment of macrocytic anemias in adults. J Gen Fam Med [Internet]. 2017 Oct 13 [cited 2018 Jun 25];18(5):200-4. Available from: http://doi.wiley.com/10.1002/jgf2.31

3. Taghizadeh M. Megaloblastic anemias. In: Clinical hematology and fundamentals of hemostasis. 5th ed. Philadelphia: F.A. Davis Company; 2009. p. 138-55.

4. Goossen LH. Anemias caused by defects of DNA metabolism. In: Rodak's hematology clinical applications and principles. 5th ed. St. Louis, Missouri: Saunders; 2015. p. 314-30. 


\section{7}

\section{Aplastic Anemia}

\section{MICHELLE TO AND VALENTIN VILLATORO}

\section{Bone Marrow Failure:}

Bone marrow failure is characterized by reduced hematopoiesis in the bone marrow resulting in cytopenias in one or more cell lines. Decreased hematopoiesis can be attributed to: ${ }^{1}$

1. Destruction of hematopoietic stem cells due to acquired causes

2. Destruction of hematopoietic stems cells due to inherited causes

3. Ineffective erythropoiesis

4. Disruption of bone marrow microenvironment

5. Reduced production of growth factors and hormones related to hematopoiesis

6. Infiltration of the bone marrow

Aplastic anemia is a bone marrow failure syndrome that is characterized by a decreased cell count in all cell lines (pancytopenia) and a hypocellular (aplastic) bone marrow. (McKenzie ch 16 pg 303, Rodak ch 22 pg 332) Unlike other anemias, hepatosplenomegaly and lymphadenopathy are absent. (McKenzie ch $16 \mathrm{pg} 307)$

\section{Cause(s):}

There is no known, single cause of aplastic anemia but it's development can be associated with a variety of clinical states and agents which can be either acquired or inherited. ${ }^{1,2}$ It is thought that acquired causes of aplastic anemia can lead to an immunologic response against one's own hematopoietic stem cells. ${ }^{1}$ 
Table 1. List of acquired and inherited causes of aplastic anemia. ${ }^{1-3}$

\author{
Acquired: \\ Idiopathic \\ Drugs and Chemicals \\ Radiation \\ Infectious agents \\ Clonal Disorders (e.g. MDS, PNH)
}

\author{
Inherited: \\ Fanconi Anemia (autosomal recessive, rare X-linked \\ recessive) \\ Dyskeratosis congenita \\ Shwachman-Diamond Syndrome
}

\title{
Laboratory Features of Aplastic Anemia: ${ }^{1,3}$
}

\begin{tabular}{lll}
\hline CBC: & PBS: & BM: \\
RBC: Decreased & Pancytopenia & Hypocellular or dry tap \\
WBC: Decreased & (Thrombocytopenia, neutropenia, anemia) & Fatty infiltration \\
PLT: Decreased & Normochromic & \\
Hb: Decreased & Normocytic or macrocytic & \\
RETIC: Decreased & & \\
MCV: Normal to increased & & \\
Iron Studies: & Other Tests: & \\
Serum Iron: Increased & Molecular testing \\
Ferritin: Increased & Flow cytometry & \\
Transferrin: Normal & & \\
Transferrin Saturation: Normal to increased & &
\end{tabular}

\section{References:}

1. Lo C, Glader B, Sakamoto KM. Bone marrow failure. In: Rodak's hematology clinical applications and principles. 5th ed. St. Louis, Missouri: Saunders; 2015. p. 331-47.

2. Laudicina R. Hypoproliferative anemias. In: Clinical laboratory hematology. 3rd ed. New Jersey: Pearson; 2015. p. 302-16.

3. Perkins SL. Aplastic anemia including pure red cell aplasia, congenital dyserythropoietic anemia, and paroxysmal nocturnal hemoglobinuria. In: Clinical hematology and fundamentals of hemostasis. 5th ed. Philadelphia: F.A. Davis Company; 2009. p. 156-75. 
VI

RED BLOOD CELLS: INTRODUCTION TO HEMOLYTIC ANEMIAS 


\section{8 \\ Introduction to Hemolytic Anemias}

MICHELLE TO AND VALENTIN VILLATORO

Hemolytic anemia refers to a process where there is increased red blood cell destruction or decreased red blood cell survival (hemolysis) leading to a drop in the measured hemoglobin (anemia). ${ }^{1}$

The type of hemolysis can be categorized into different categories based on the location of the hemolysis (intravascular or extravascular) or the cause (intrinsic or extrinsic).

Intravascular and extravascular refers to the location of the hemolytic process, whether the process is taking place within the blood vessels (intra) or outside the blood vessels (extra). ${ }^{2}$

Intrinsic and extrinsic refers to the cause of red blood cell destruction relative to the red blood cell itself. If the cause is due to an issue with the red blood cell (e.g. inherited defects of the RBC), it is referred to as being intrinsic. If the cause is due to factors from outside the red blood cell (e.g. environment), it is referred to as being extrinsic. ${ }^{2}$

Compensated hemolysis refers to the ability of the bone marrow to increase red blood cell production in order to compensate for the rate of hemolysis. As a result, anemia does not develop. ${ }^{2}$

\section{Extravascular (Macrophage-mediated) Hemolysis}




\section{(EVH)}

Process: ${ }^{1,3-5}$

1. RBCs are phagocytized in the spleen, bone marrow, or liver by macrophages.

2. Hemoglobin is broken down into iron, globin, and the protoporphyrin ring.

3. Iron is carried by transferrin to the bone marrow be reused or stored as ferritin or hemosiderin.

4. Globin is broken down into amino acids to be recycled.

5. The protoporphyrin ring is further is broken down to biliverdin and then to unconjugated bilirubin in the macrophage.

6. Unconjugated bilirubin is then released and carried by albumin to the liver.

7. In the liver, unconjugated bilirubin is converted to conjugated bilirubin (bilirubin diglucuronide).

8. Conjugated bilirubin is excreted with bile into the intestines where it is converted into urobilinogen by bacteria.

9. A majority of the urobilinogen is then excreted in feces, a small amount is reabsorbed by the kidney, and another portion is excreted into the urine.

\section{Intravascular (Fragmentation) Hemolysis (IVH)}

Process: ${ }^{3-5}$

1. RBC hemolysis occurs in the blood vessels and hemoglobin is released into circulation.

2. Hemoglobin dissociates into $\alpha \beta$ dimers and is picked up by Haptoglobin where it is carried to the liver.

3. Subsequent catabolic steps are the same as extravascular hemolysis from the liver onwards.

4. If haptoglobin is not available, the $\alpha \beta$ dimers become oxidized into methemoglobin where it is 
broken down into metheme and globin.

5. Metheme is carried by hemopexin to the liver.

6. If hemopexin is not available, metheme binds albumin instead to form methalbumin,.

7. Methemalbumin continues to circulate the body until hemopexin becomes available.

Table 1. Comparison of IVH and EVH Laboratory Findings ${ }^{1-3}$

Test

RBC, Hct, Hb

Total Bilirubin

LDH

Haptoglobin

Hemopexin

Hemosiderinuria

Hemoglobinuria

RBC Morphology

Examples
IVH

Decreased

Increased

Increased

Decreased

Decreased

Present

Present

Schistocytes
EVH

Decreased

Increased

Slightly Increased

Slightly Decreased

Slightly Decreased

Absent

Absent

Spherocytes
PNH, PCH, MAHAs, Mechanical trauma, Bacterial Infections, Thermal Injury
Thalassemia (Other hemoglobinopathies), Enzymopathies, Membranopathies, Megaloblastic anemia, Autoimmune hemolytic anemia, Drug-induced hemolytic anemia 


\section{References:}

1. Barcellini W, Fattizzo B. Clinical Applications of Hemolytic Markers in the Differential Diagnosis and Management of Hemolytic Anemia. Dis Markers [Internet]. 2015 Dec 27 [cited 2018 Jun 26];2015:635670. Available from: http://www.ncbi.nlm.nih.gov/pmc/articles/PMC4706896/

2. McKenzie SB, Otto CN. Introduction to anemias. In: Clinical laboratory hematology. 3rd ed. New Jersey: Pearson; 2015. p.178-97.

3. Doig K. Introduction to increased destruction of erythrocytes. In: Rodak's hematology clinical applications and principles. 5th ed. St. Louis, Missouri: Saunders; 2015. p. 348-66.

4. McKenzie SB. Hemoglobin. In: Clinical laboratory hematology. 3rd ed. New Jersey: Pearson; 2015. p. 77-96.

5. Harmening DM. The red blood cell: structure and function. In: Clinical hematology and fundamentals of hemostasis. 5th ed. Philadelphia: F.A. Davis Company; 2009. p. 64-81. 


\section{VII \\ RED BLOOD CELLS: \\ HEMOGLOBINOPATHIES}




\section{9 \\ Normal Hemoglobin Structure}

\section{MICHELLE TO AND VALENTIN VILLATORO}

\section{Location of globin genes: ${ }^{1}$}

Chromosome 16: $\alpha$ globin genes

Chromosome 11: $\beta$ globin genes

One $\alpha$ globin gene and one $\beta$ globin gene are inherited from each parent.

Normal hemoglobin A is made up of two $\alpha$ globin chains, two $\beta$ globin chains, and four heme molecules.

Heme is formed from protoporphyrin ring precurosors and ferrous iron $\left(\mathrm{Fe}^{2+}\right)$.

Table \#1 Normal hemoglobin content at various stages of life. ${ }^{1}$

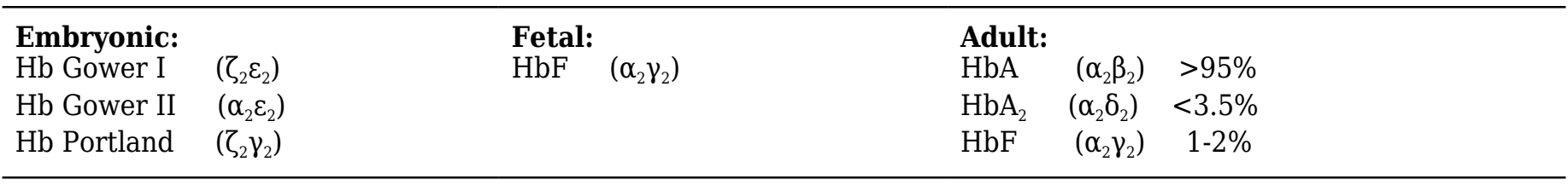

\section{References:}

1. Keohane EM. Hemoglobin metabolism. In: Rodak's hematology clinical applications and principles. 5th ed. St. Louis, Missouri: Saunders; 2015. p. 124-36. 


\section{0}

\section{Sickle Cell (Hemoglobin SS) Disease}

\section{MICHELLE TO AND VALENTIN VILLATORO}

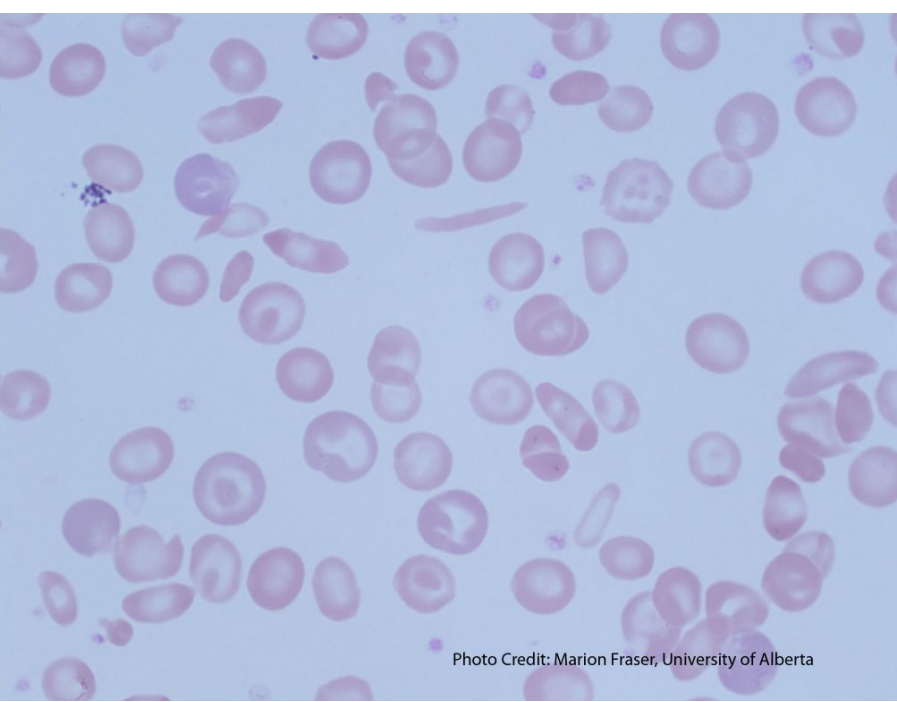

An image of a peripheral blood smear of a patient with sickle cell disease. From MLS Collection, University of Alberta, https://doi.org/10.7939/R3G737K46

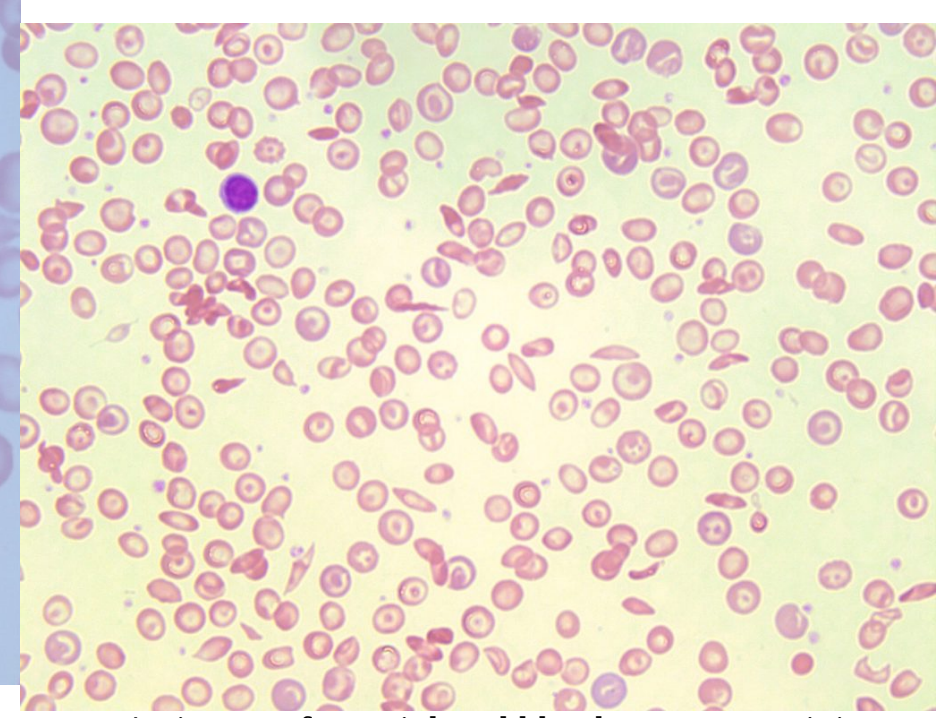

An image of a peripheral blood smear containing sickle cells, target cells, and increased polychromasia. 50x oil immersion. From MLS Collection, University of Alberta, https://doi.org/10.7939/R3XP6VJ98

\section{Cause(s):}

$\beta$ globin chain amino acid substitution in the 6th position from glutamic acid (Glu) to valine (Val). In the homozygous form of the disease, both $\beta$ globin genes are affected. ${ }^{1}$

\section{Inheritance:}

Autosomal dominant ${ }^{2}$

\section{Demographics: ${ }^{3}$}


Tropical Africa

Mediterranean Areas

Sickle cell disease is common in areas where malaria is prominent and it is suggested that the disease acts as a protective factor for malaria. This protection is only seen in heterozygotes, as homozygotes often lose splenic function, which is essential for combating the parasite.

\section{Cellular Features: ${ }^{1-4}$}

See sickle cell (drepanocytes) under RBC morphology for more information about cell formation.

The formation of sickle cells becomes irreversible over time leading to the formation of rigid and "sticky" sickle cell aggregates resulting in many complications.

\section{Complications: ${ }^{1-4}$}

Chronic hemolytic anemia

Vaso-occlusion (can lead to ischemic tissue injury, splenic sequestration of RBCs, autosplenectomy)

Prone to infections

Nephropathies

Stroke

\section{Laboratory Features of Sickle Cell Disease: ${ }^{2-4}$}


CBC:

RBC: Decreased

WBC: Increased

PLT: Increased

$\mathrm{Hb}$ : Decreased

RETIC: Increased

RDW: Increased
PBS:

Sickle cells

Normochromic, normocytic RBCs

Target cells

Polychromasia

nRBCs

Howell-Jolly bodies

Pappenheimer bodies

Basophilic Stippling
Hemoglobin Electrophoresis:

Hb S: $80-95 \%$

Hb A: None

$\mathrm{Hb} \mathrm{A}: 2-\%$

Hb F: 5-20\%

\section{Other Tests:}

Solubility Screen: Positive

Metasulfite Sickling Test: Positive

HPLC

Hemoglobin Electrophoresis
BM:

Erythroid Hyperplasia

Iron stores: often increased

\section{References:}

1. Chonat S, Quinn CT. Current standards of care and long term outcomes for thalassemia and sickle cell disease. Adv Exp Med Biol [Internet]. 2017 [cited 2018 Jun 5];1013:59-87. Available from: http://www.ncbi.nlm.nih.gov/pmc/articles/PMC5720159/

1. Randolph TR. Hemoglobinopathies (structural defects in hemoglobin). In: Rodak's hematology clinical applications and principles. 5th ed. St. Louis, Missouri: Saunders; 2015. p. 426-453.

3. Laudicina RJ. Hemoglobinopathies: qualitative defects. In: Clinical laboratory hematology. 3rd ed. New Jersey: Pearson; 2015. p.231-50.

4. Harmening DM, Yang D, Zeringer H. Hemolytic anemias: extracorpuscular defects. 5th ed. Philadelphia: F.A. Davis Company; 2009. p. 250-79). 


\section{1 \\ Sickle Cell Trait (Hemoglobin AS)}

\section{MICHELLE TO AND VALENTIN VILLATORO}

\section{Cause(s):}

$\beta$ globin chain amino acid substitution in the 6th position from glutamic acid (Glu) to valine (Val). Only one $\beta$ globin genes is affected. ${ }^{1,2}$

\section{Inheritance:}

Heterozygous state where one normal $\beta$ globin gene and one affected $\beta$ globin gene are inherited. ${ }^{3}$

\section{Clinical Findings: ${ }^{1-3}$}

Due to the presence of $\mathrm{Hb} \mathrm{A}$ and reduced concentration of $\mathrm{HB} \mathrm{S}$, polymerization of $\mathrm{Hb} \mathrm{S}$ and sickling of red blood cells does not normally occur. As a result, condition is mostly benign and asymptomatic.

Sickling can still occur under extremely low hypoxic conditions.

\section{Laboratory Features: ${ }^{1-3}$}


CBC:

All parameters (Even $\mathrm{Hb}$ ) are normal
PBS:

Absence of sickle cells

PBS appears normal

(may see a slight increase in target cells)

Other Tests:

Solubility Screen: Positive

Metasulfite Sickling Test: Positive

HPLC

Hemoglobin Electrophoresis
BM:

N/A

\section{Hemoglobin Electrophoresis:}

Hb A: $50-65 \%$

$\mathrm{Hb} \mathrm{A}$ : Normal

Hb F: Normal

$\mathrm{Hb}$ A:Hb S is $\sim 60: 40$

\section{References:}

1. Laudicina RJ. Hemoglobinopathies: qualitative defects. In: Clinical laboratory hematology. 3rd ed. New Jersey: Pearson; 2015. p.231-50.

2. Harmening DM, Yang D, Zeringer H. Hemolytic anemias: extracorpuscular defects. 5th ed. Philadelphia: F.A. Davis Company; 2009. p. 250-79).

3. Randolph TR. Hemoglobinopathies (structural defects in hemoglobin). In: Rodak's hematology clinical applications and principles. 5th ed. St. Louis, Missouri: Saunders; 2015. p. 426-453. 


\section{2 \\ Hemoglobin C (Hb CC) Disease}

\section{MICHELLE TO AND VALENTIN VILLATORO}

\section{Cause(s):}

$\beta$ globin chain amino acid substitution in the 6 th position from glutamic acid (Glu) to lysine (Lys). ${ }^{1,2}$

\section{Inheritance:}

Autosomal dominant ${ }^{1}$

\section{Demographics:}

West Africa $^{1}$

\section{Clinical Features: ${ }^{1-3}$}

See Hemoglobin C under RBC inclusions for additional information.

Less splenic sequestration and milder chronic hemolysis compared to sickle cell disease. Patients are usually asymptomatic.

\section{Laboratory Features: ${ }^{1,2}$}




\section{CBC:}

Hb: Decreased

Hct: Decreased
PBS:

Normochromic, normocytic RBCs

$* \mathrm{Hb} \mathrm{C}$ crystals

Target cells

nRBCs
BM:

N/A
Other Tests:

Solubility Screen: Negative

Metasulfite Sickling Test: Negative

HPLC

Hemoglobin Electrophoresis

$\mathrm{Hb} \mathrm{A}_{2}$ : Normal

Hb F: $<7 \%$

*Not always seen, more likely in patients who have had a splenectomy.

\section{References:}

1. Laudicina RJ. Hemoglobinopathies: qualitative defects. In: Clinical laboratory hematology. 3rd ed. New Jersey: Pearson; 2015. p.231-50.

2. Randolph TR. Hemoglobinopathies (structural defects in hemoglobin). In: Rodak's hematology clinical applications and principles. 5th ed. St. Louis, Missouri: Saunders; 2015. p. 426-453.

3. Harmening DM, Yang D, Zeringer H. Hemolytic anemias: intracorpuscular defects. 5th ed. Philadelphia: F.A. Davis Company; 2009. p. 207-29). 


\section{3}

Hemoglobin SC Disease

\section{MICHELLE TO AND VALENTIN VILLATORO}

\section{Cause(s):}

Both $\beta$ globin chains are affected as both genes for hemoglobin $\mathrm{S}$ and hemoglobin $\mathrm{C}$ are both inherited. ${ }^{1,2}$

\section{Clinical Features: ${ }^{1}$}

Complication is less severe than sickle cell disease but more severe than hemoglobin $\mathrm{C}$ disease. Cells are still prone to sickling under decreased oxygen tension.

Complications are similar to those seen in sickle cell anemia and vaso-occlusion can occur.

\section{Laboratory Features: ${ }^{1,2}$}

\begin{tabular}{lll}
\hline CBC: & PBS: & BM: \\
Hb: Decreased & Normochromic & N/A \\
Hct: Decreased & Normocytic & \\
MCHC: Increased & Target Cells & \\
& HbSC crystals & \\
Hemoglobin Electrophoresis: & Other Tests: & \\
Hb S: $45 \%$ & Solubility Tests: Positive & \\
Hb C: $45 \%$ & HPLC & \\
Hb A: None & Hemoglobin Electrophoresis \\
Hb A $2: 4 \%$ & & \\
Hb F: $1 \%$ & & \\
\hline
\end{tabular}

\section{References:}

1. Laudicina RJ. Hemoglobinopathies: qualitative defects. In: Clinical laboratory hematology. 3rd ed. 
New Jersey: Pearson; 2015. p.231-50.

2. Randolph TR. Hemoglobinopathies (structural defects in hemoglobin). In: Rodak's hematology clinical applications and principles. 5th ed. St. Louis, Missouri: Saunders; 2015. p. 426-453. 


\section{VIII \\ RED BLOOD CELLS: EXTRINSIC \\ DEFECTS CAUSING HEMOLYTIC ANEMIAS}




\section{4 \\ Microangiopathic Hemolytic Anemias \\ (MAHAs)}

MICHELLE TO AND VALENTIN VILLATORO

An interactive or media element has been excluded from this version of the text. You can view it online here:

https://pressbooks.library.ualberta.ca/mlsci/?p=464

Images of peripheral blood smears demonstrating features of microangiopathic hemolytic anemia . Note the presence of schistocytes, increased polychromasia, and lack of platelets. From MLS Collection, University of Alberta.

Image 1: 50x oil immersion. https://doi.org/10.7939/R3FX74D2V

Image 2: 100 oil immersion. https://doi.org/10.7939/R3B56DK8D

Image 3: 50x oil immersion. https://doi.org/10.7939/R3639KM46

\section{Introduction: ${ }^{1,2}$}

Microangiopathic hemolytic anemias are a group of disorders that involve the fragmentation of red blood cells in the circulation due to the formation of microthrombi in the microvasculature. This results in intravascular hemolysis and thrombocytopenia.

Red blood cells are physically damaged as they pass through blood vessels resulting in the formation of schistocytes (intravascular hemolysis). The damaged red blood cells are then often removed from circulation by the spleen resulting in extravascular hemolysis.

These features can be found in certain clinical states: 
1. Disseminated Intravascular Coagulation (DIC)

2. Thrombotic thrombocytopenic purpura (TTP)

3. Hemolytic-uremic syndrome (HUS)

4. HELLP Syndrome (Hemolysis, Elevated liver enzymes and Low platelets)

\section{General Laboratory Findings of MAHAs: ${ }^{3}$}

\begin{tabular}{lll}
\hline CBC: & PBS: & Other Tests: \\
PLT: Decreased & Schistocytes & Unconjugated Bilirubin: Increased \\
Hb: Decreased & Polychromasia & LDH: Increased \\
RETIC: ncreased & nRBCs & Haptoglobin: Decreased \\
& & Urine urobilinogen: Increased \\
& & Variable hemoglobinuria and hemoglobinemia
\end{tabular}

\section{References:}

1. Smith LA. Hemolytic anemia: nonimmune defects. In: Clinical laboratory hematology. 3rd ed. New Jersey: Pearson; 2015. p.372-87.

2. Harmening DM, Yang D, Zeringer H. Hemolytic anemias: extracorpuscular defects. 5th ed. Philadelphia: F.A. Davis Company; 2009. p. 250-79).

2. Keohane EM. Extrinsic defects leading to increased erythrocyte destruction - nonimmune causes. In: Rodak's hematology clinical applications and principles. 5th ed. St. Louis, Missouri: Saunders; 2015. p. 394-410. 


\section{5 \\ Macroangiopathic Hemolytic Anemias}

MICHELLE TO AND VALENTIN VILLATORO

\section{Traumatic Cardiac Hemolytic Anemia}

In this condition, hemolysis is due to mechanical trauma caused by prosthetic cardiac valves. High blood flow around the prosthetic causes red blood cells to fragment leading to intravascular hemolysis. Any damaged cells that do not hemolyze in circulation are removed by the spleen via extravascular hemolysis. ${ }^{1,2}$

Hemolytic anemia due to traumatic cardiac causes is uncommon and platelet count is not usually decreased drastically. Any hemolysis that occurs is often compensated by the bone marrow. ${ }^{1,2}$

Laboratory Findings for Traumatic Cardiac Hemolytic Anemia: ${ }^{2}$

\begin{tabular}{lll}
\hline CBC: & PBS: & Other Tests: \\
PLT: Normal & Schistocytes & Unconjugated Bilirubin: Increased \\
Hb: Decreased & & LD: Increased \\
RETIC: Increased & & Haptoglobin: Decreased
\end{tabular}

\section{Exercise-induced Hemoglobinuria}

Transient hemolysis that occurs due to stress caused by exercise. Most often due to activities involving contact with hard surfaces such as running. Red blood cells become damaged as they pass through 
small vessels. Anemia usually does not develop unless hemolysis is severe. ${ }^{1}$

\section{Laboratory Findings for Exercise-induced Hemoglobinuria: ${ }^{2}$}

\section{CBC:}

Hb: Increased

RETIC: Increased

MCV: Slight increase

\section{PBS:}

Schistocytes are NOT present

\section{Other Tests:}

Unconjugated Bilirubin: Increased

LDH: Increased

Haptoglobin: Decreased

Hemoglobinuria

\section{Thermal Injury}

Hemolytic anemia can develop after thermal burns to the body. Degree of hemolysis is dependent on the amount of surface area affected. Hemolysis is due to direct thermal damage to the red blood cells. ${ }^{1}$

\section{Laboratory Findings for Thermal Injury: ${ }^{1}$}

\begin{tabular}{lll}
\hline CBC: & PBS: & Other Tests: \\
Hb: Decreased & Schistocytes & Hemoglobinuria \\
& Micro-Spherocytes &
\end{tabular}

\section{References:}

1. Smith LA. Hemolytic anemia: nonimmune defects. In: Clinical laboratory hematology. 3rd ed. New Jersey: Pearson; 2015. p.372-87.

2. Keohane EM. Extrinsic defects leading to increased erythrocyte destruction - nonimmune causes. In: 
Rodak's hematology clinical applications and principles. 5th ed. St. Louis, Missouri: Saunders; 2015. p. 394-410. 


\section{6}

Immune-Mediated Hemolytic Anemias

\section{MICHELLE TO AND VALENTIN VILLATORO}

Hemolytic anemias can be caused by antibodies that can be directed against self (auto-antibodies) or foreign (allo-antibodies) antigens. Antibodies implicated vary in immunoglobulin class and optimal temperature of reactivity.

Table 1. Comparison of Warm and Cold Reacting Antibodies. ${ }^{1}$

\begin{tabular}{|c|c|c|}
\hline & Warm & Cold \\
\hline Immunoglobulin Class & IgG & $\begin{array}{l}\text { IgM } \\
\text { (Exception: autoanti- } P \text { is IgG) }\end{array}$ \\
\hline Optimal Temperature & $37^{\circ} \mathrm{C}$ & $\begin{array}{l}<30^{\circ} \mathrm{C} \text { (often at } 4^{\circ} \mathrm{C} \text { ) } \\
\text { Pathological cold agglutinins react closer to body } \\
\text { temperature }\end{array}$ \\
\hline Mechanism of Hemolysis & $\begin{array}{l}\text { Extravascular } \\
\text { IgG or C3b attachment to macrophages }\end{array}$ & $\begin{array}{l}\text { Extravascular or Intravascular } \\
\text { Complement-mediated }\end{array}$ \\
\hline Specificity & anti-Rh (Broad specificity) & $\begin{array}{l}\text { Autoanti-I } \\
\text { Autoanti-i } \\
\text { Autoanti-P }\end{array}$ \\
\hline
\end{tabular}

Warm Auto-Immune Hemolytic Anemia (WAIHA) 
Lymphoproliferative diseases (e.g. Chronic lymphocytic leukemia)

Other autoimmune diseases: systemic lupus erythematosus, rheumatoid arthritis

Ingestion of certain drugs

Some non lymphoid neoplasms

Some inflammatory diseases

Affected age: Usually old age ( $>40$ years old). ${ }^{1}$

Antibody Specificity: Panreactive, polyclonal anti-Rh (IgG). ${ }^{3}$

\section{Pathophysiology:}

Often due to a Pan-reacting antibody against the $\mathrm{Rh}$ blood group system causing extravascular hemolysis. The antibodies bind to the red blood cells, resulting in their removal by macrophages in the spleen. Incomplete phagocytosis results in the removal of only some of the red blood cell membrane allowing the rest to reform. This reformation changes the red blood cell shape, and it becomes as spherocyte. Red blood cells can also be coated with complement along with IgG antibodies as another mechanism of opsonization and removal from circulation. ${ }^{3}$

\section{Laboratory Findings for WAIHA: ${ }^{1-3}$}

\begin{tabular}{|c|c|c|}
\hline CBC: & PBS: & BM: \\
\hline WBC: Normal to increased & Normochromic & Erythroid hyperplasia \\
\hline PLT: Normal to increased & Normocytic & Erythrophagocytosis by macrophages \\
\hline Hb: Decreased & Spherocytes & \\
\hline RETIC: Increased & $\begin{array}{l}\text { Polychromasia } \\
+/- \text { nRBCs }\end{array}$ & \\
\hline \multicolumn{3}{|l|}{ Other Tests: } \\
\hline \multicolumn{3}{|l|}{ DAT: Positive (IgG \& C3b) } \\
\hline \multicolumn{3}{|l|}{ Osmotic Fragility: Increased } \\
\hline \multicolumn{3}{|c|}{ Antibody Screen: Positive with all cells } \\
\hline \multicolumn{3}{|l|}{ Autocontrol: Positive } \\
\hline \multicolumn{3}{|l|}{ Bilirubin: Increased } \\
\hline \multicolumn{3}{|l|}{ Haptoglobin: Decreased } \\
\hline \multicolumn{3}{|l|}{ LD: Increased } \\
\hline \multicolumn{3}{|l|}{ Hemoglobinuria: Positive } \\
\hline Hemosiderinuria: Positive & & \\
\hline
\end{tabular}




\section{Cold Agglutinin Disease (CAD)}

\section{Associated Conditions: ${ }^{2}$}

Primarily idiopathic

B-cell lymphoproliferative neoplasms

Mycoplasma pneumoniae (anti-I)

Infectious mononucleosis (anti-i)

Affected age: $>50$ years old. ${ }^{2}$

Antibody Specificity: Autoanti-I and autoanti-i. ${ }^{2}$

Autoantibody is an $\operatorname{IgM}$ antibody that reacts optimally below body temperature, usually around $4^{\circ} \mathrm{C}^{2}$. Pathological cold agglutinins will react closer to body temperature (around $30^{\circ} \mathrm{C}$ ).

Can be polyclonal (i.e. infections) or monoclonal (Monoclonal is more pathogenic). ${ }^{1}$

\section{Pathophysiology:}

Under cold temperatures (circulation in the extremities), the autoantibodies bind to the red blood cells causing them to agglutinate. As the autoantibodies are strong complement activators, complement (C3b) also binds the red blood cells. ${ }^{1,2,4}$ 
When the cells return to body temperature (central circulation), the autoantibody unbinds allowing cells to separate and leaves C3b behind remaining on the red blood cell. This leads to complementmediated hemolysis by macrophages in the liver (extravascular hemolysis). ${ }^{1,2,4}$

Can cause acrocyanosis and hemolysis is self-limiting. ${ }^{5}$

\title{
Laboratory Findings for CAD: ${ }^{1,2,4}$
}

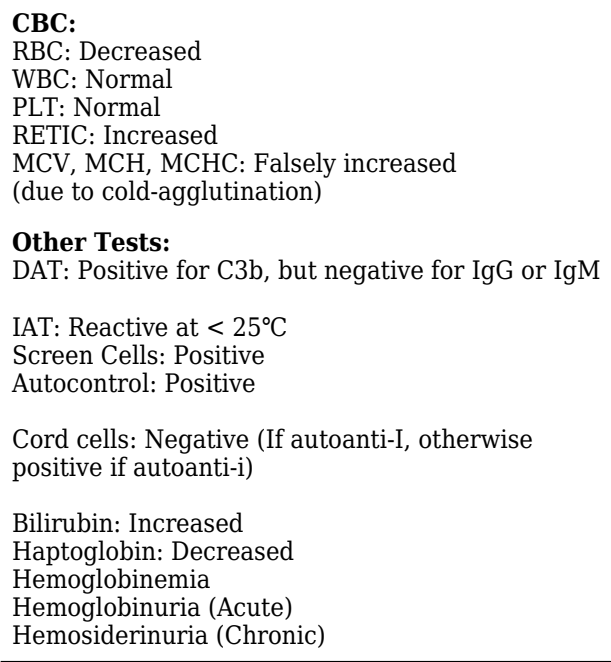

Other Tests:

DAT: Positive for C3b, but negative for IgG or IgM

IAT: Reactive at $<25^{\circ} \mathrm{C}$

Screen Cells: Positive

Autocontrol: Positive

Cord cells: Negative (If autoanti-I, otherwise

positive if autoanti-i)

Bilirubin: Increased

Haptoglobin: Decreased

Hemoglobinemia

Hemoglobinuria (Acute)

Hemosiderinuria (Chronic)

PBS:

Agglutination at room temperature (Not present if sample is heated to $37^{\circ} \mathrm{C}$ )

Spherocytes

Normohromic

Normocytic

$+/-$ nRBCs
BM:

Erythroid hyperplasia

\section{Paroxysmal Cold Hemoglobinuria (PCH)}

\author{
Associated Conditions: ${ }^{2,3}$
}

Can develop following viral infections or upper respiratory infections

Affected age: Primarily in children. ${ }^{2}$

Antibody Specificity: autoanti-P (IgG, polyclonal, binds optimally at $4-20^{\circ} \mathrm{C}$, reactive at $\left.37^{\circ} \mathrm{C}\right) .{ }^{1,4,5}$ 


\section{Pathophysiology: ${ }^{1,45}$}

Attachment of autoanti-P to cells do not cause the cells to agglutinate but does result in an intravascular, complement-mediated hemolysis.

Autoanti-P is a biphasic antibody meaning that it activates only partial complement at cold temperatures $\left(<37^{\circ} \mathrm{C}\right)$ and full complement at warmer temperatures $\left(37^{\circ} \mathrm{C}\right)$ leading to hemolysis.

\section{Laboratory Findings for PCH: ${ }^{2-4}$}

\begin{tabular}{lll}
\hline CBC: & PBS: & Other Tests: \\
WBC: Normal & Spherocytes & DAT: Positive for C3d only \\
Hb: Decreased & Polychromasia & LD: Increased \\
RETIC: Increased & +/-nRBCs & Haptoglobin: Decreased \\
& Some Schistocytes & Hemoglobinemia \\
& & Hemoglobinuria \\
& & Donath-Landsteiner Test is Positive: \\
& & Control incubated at 37 $7^{\circ} \mathrm{C}:$ Hemolysis absent \\
& & Patient sample incubated at 37 $37^{\circ} \mathrm{C}$ only: Hemolysis absent \\
& Patient sample incubated at $4{ }^{\circ} \mathrm{C}$ and $37^{\circ} \mathrm{C}:$ Hemolysis present
\end{tabular}

Table 2. Comparative Table of Warm and Cold Immune-Related Hemolytic Anemias

\begin{tabular}{cccc}
\hline & WAIHA & CAD & PCH \\
Age (years old) & $>40$ & $>50$ & $\begin{array}{c}\text { Children } \\
\text { (After viral infection) }\end{array}$ \\
Antibody Class & IgG & IgM & IgG \\
Antibody Specificity & Anti-Rh (most-often) & Anti-I, Anti-i & Anti-P \\
Optimal Binding Temperature & $37^{\circ} \mathrm{C}$ & $4^{\circ} \mathrm{C}$ & $<20^{\circ} \mathrm{C}$ \\
DAT Reactivity & IgG & IgG, C3d & C3d \\
Donath-Landsteiner Test & N/A & Negative & Positive \\
Type of Hemolysis & Extravascular & Extravascular & Intravascular \\
\hline
\end{tabular}




\section{Drug-Induced Immune Hemolytic Anemia}

Immune hemolytic anemias can also be induced when certain drugs are administered into the body. There are four mechanisms in which they are able to do this:

\section{Autoantibody Induction ${ }^{1,4,6}$}

Most commonly caused by methyldopa.

Mechanism mimics that found in warm autoimmune hemolytic anemia. The drug induces the production of warm-reactive antibodies against the red blood cell membrane (self-antigens). Antibodies bind at $37^{\circ} \mathrm{C}$ and affected red cells are removed by the spleen through extravascular hemolysis.

\section{Drug Adsorption (Hapten) ${ }^{1,4,6}$}

Most commonly caused by penicillins.

The drug is non-specifically adsorbed onto the red blood cells and antibodies are produced against the drug itself. As red blood cell pass through the spleen, they are removed by macrophages.

\section{Immune Complex Formation (Innocent Bystander) ${ }^{1,4,6}$}

Most commonly caused by quinidine.

An IgG or IgM antibody is produced against the drug when it loosely binds to the red blood cells (antibody-drug immune complex). The immune complex induces the activation of complement, leading to the formation of membrane attack complexes and intravascular hemolysis.

\section{Membrane Modification ${ }^{1,6}$}


Most commonly caused by cephalosporins.

Drug modifies the red blood cell membrane causing it to become "sticky". This results in red blood cells becoming coated with many plasma proteins. No hemolysis occurs, but DAT testing will be positive.

\section{Table 3. Comparison of Mechanisms Leading to Drug-Related Immune Hemolytic Anemia}

$\begin{array}{ccccc}\text { Drug Example } & \begin{array}{c}\text { Autoantibody } \\ \text { Induction }\end{array} & \text { Drug Adsorption } & \text { Immune Complex } & \text { Membrane Modification } \\ \text { Antibody Class } & \text { Methyldopa } & \text { Penicillins } & \text { Quinidine } & \text { Cephalosporins } \\ \text { DAT } & \text { IgG } & \text { IgG } & \text { IgG or IgM } & \text { N/A, due to plasma proteins } \\ & \text { IgG Positive } & \text { IgG Positive } & \text { C3 Positive } & \text { Positive, due to plasma } \\ \text { C3 Negative } & \text { C3 Negative } & \text { IgG Variable } & \\ \text { Eluate } & & & & \text { Usually Negative }\end{array}$

Type of Hemolysis

Extravascular

Extravascular

Intravascular

No hemlysis

\section{Alloimmune Hemolytic Anemias}

Hemolytic anemias can also occur with there is sensitization of red blood cells due previous exposure to another individual's red blood cells.

\section{Hemolytic Transfusion Reactions ${ }^{7}$}

Hemolytic transfusion reactions occur when there is an incompatibility between the patient's blood (contain alloantibodies) and the transfused cells. Alloantibodies present in the patient's blood binds the 
antigens on the transfused cells and this results in hemolysis. Transfusion reactions are classified as being acute or delayed.

Table 4. Comparison of Acute and Delayed Transfusion Reactions.

\begin{tabular}{|c|c|c|}
\hline & Acute & Delayed \\
\hline Time & Immediate; minutes to hours & Days to weeks \\
\hline $\begin{array}{l}\text { Related Blood } \\
\text { Groups }\end{array}$ & $\mathrm{ABO}$ & Other non-ABO blood groups \\
\hline Symptoms & $\begin{array}{c}\text { Fever, chills, back pain, pain at infusion site, difficulty breathing, } \\
\text { hypotension, urticaria, tachycardia }\end{array}$ & Usually show no clinical symptoms but may develop a fever \\
\hline Type of Hemolysis & Intravascular & Extravascular \\
\hline DAT & Negative (if all transfused cells have all been hemolyzed) & $\begin{array}{c}\text { Positive for IgG and/or C3d (Can be negative depending on time } \\
\text { of sample collection) }\end{array}$ \\
\hline $\begin{array}{l}\text { Other Laboratory } \\
\text { Findings }\end{array}$ & $\begin{array}{l}\text { Hemoglobinemia } \\
\text { Hb: Decreased } \\
\text { Bilirubin: Increased after a few days } \\
\text { Haptoglobin: Decreased }\end{array}$ & $\begin{array}{l}\text { Hemoglobinuria } \\
\text { Hb: Variable } \\
\text { Bilirubin: Increased } \\
\text { Eluate is positive for offending antibody. }\end{array}$ \\
\hline
\end{tabular}

\section{Hemolytic Disease of the Fetus and Newborn (HDFN)}

Hemolysis that occurs in the fetus or newborn due to incompatibility between the mother's alloantibodies and the fetus's/newborn's blood groups.

Mother's immune system can become sensitized and produce alloantibodies against the blood group antigens that she lacks during a previous pregnancy or transfusion. If the fetus/newborn contains the blood group antigens that the mother has alloantibodies against, HDFN can develop. During pregnancy, alloantibodies are able to pass through the placenta and bind to the red blood cells in the fetus/newborn resulting in hemolysis of the fetal red blood cells. ${ }^{4,6}$

Newborns appear jaundiced and have high levels of bilirubin at birth. ${ }^{4,7}$ The peripheral blood smear will show increased spherocytes, polychromasia, and increased nucleated red blood cells (normoblastemia). 
Alloantibodies can be produced against Rh, ABO, and other blood groups. ${ }^{7}$

\section{References:}

1. Smith LA. Hemolytic anemia: immune anemias. In: Clinical laboratory hematology. 3rd ed. New Jersey: Pearson; 2015. p. 348-71.

2. Barcellini W, Fattizzo B. Clinical Applications of Hemolytic Markers in the Differential Diagnosis and Management of Hemolytic Anemia. Dis Markers [Internet]. 2015 Dec 27 [cited 2018 Jun 26];2015:635670. Available from: http://www.ncbi.nlm.nih.gov/pmc/articles/PMC4706896/

3. Berentsen S. Role of complement in autoimmune hemolytic anemia. Transfus Med Hemotherapy [Internet]. 2015 Sep 7 [cited 2018 Jun 27];42(5):303-10. Available from: http://www.ncbi.nlm.nih.gov/pmc/articles/PMC4678321/

4. Przekop KA. Extrinsic defects leading to increased erythrocyte destruction - immune causes. In: Rodak's hematology clinical applications and principles. 5th ed. St. Louis, Missouri: Saunders; 2015. p. 411-25.

5. Packman $\mathrm{CH}$. The clinical pictures of autoimmune hemolytic anemia. Transfus Med Hemotherapy [Internet]. 2015 Sep 11 [cited 2018 Jun 26];42(5):317-24. Available from: http://www.ncbi.nlm.nih.gov/pmc/articles/PMC4678314/

6. Harmening DM, Yang D, Zeringer H. Hemolytic anemias: extracorpuscular defects. 5th ed. Philadelphia: F.A. Davis Company; 2009. p. 250-79).

7. Landis-Piwowar K, Landis J, Keila P. The complete blood count and peripheral blood smear evaluation. In: Clinical laboratory hematology. 3rd ed. New Jersey: Pearson; 2015. p. 154-77. 


\title{
47
}

\section{Infectious Agents}

\author{
MICHELLE TO AND VALENTIN VILLATORO
}

\section{Malarial Infection}

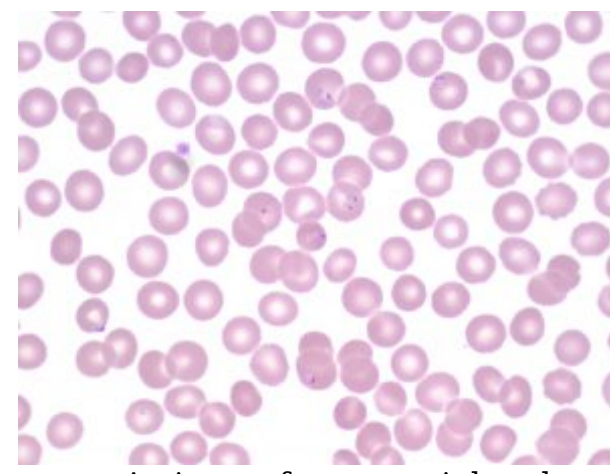

An image from a peripheral blood smear demonstrating intra-cellular malarial rings (Plasmodium falciparum) inside red blood cells. From MLS Collection, University of Alberta, https://doi.org/10.7939/R34J0B C8J

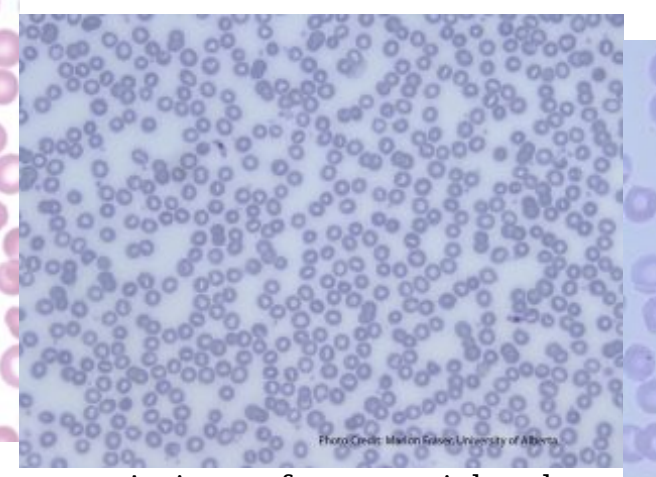

An image from a peripheral blood smear showing two crescent-shaped gametocytes, characteristic of Plasmodium falciparum. From MLS Collection, University of Alberta, https://doi.org/10.7939/R3BG2 HS02

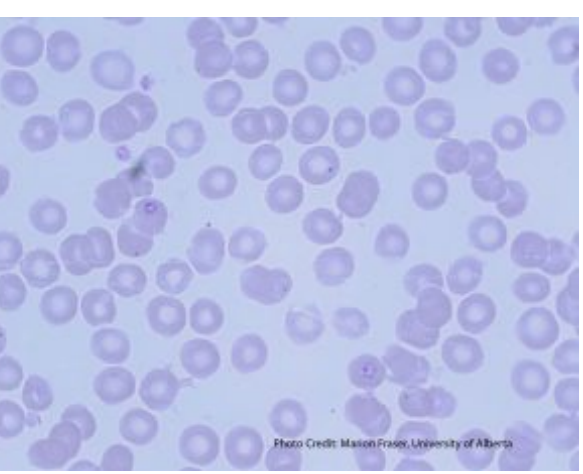

An image from a peripheral blood smear showing ring forms of Plasmodium ovale in oval-shaped red blood cells. From MLS Collection, University of Alberta, https://doi.org/10.7939/R3W08 WX95

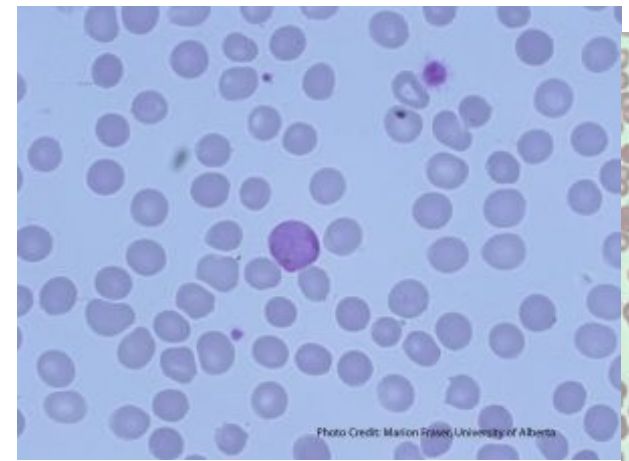

An image from a peripheral blood smear demonstrating the gametocyte of Plasmodium vivax. From MLS Collection, University of Alberta,

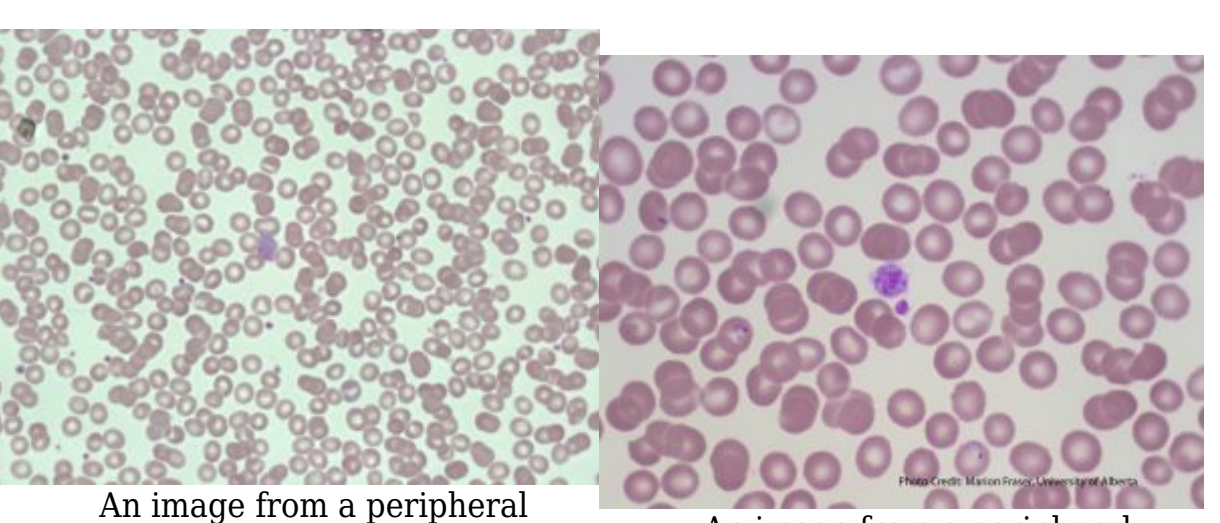
blood smear demonstrating malaria at the gametocyte stage in the center. 60X oil
An image from a peripheral blood smear showing signet ring forms of malaria and a 
https://doi.org/10.7939/R3R786

$45 \mathrm{~T}$ immersion. From MLS

Collection, University of

Alberta,

https://doi.org/10.7939/R33J39

G6B large platelet in the center. From MLS Collection, University of Alberta, https://doi.org/10.7939/R3MG7 GB25

\section{Causative Agent: ${ }^{1,2}$}

Malaria is transmitted by the female Anopheles mosquito.

There are five species of malaria:

Plasmodium falciparum - Most severe

Plasmodium vivax - Most common

Plasmodium ovale - Less common

Plasmodium malariae - Less common

Plasmodium knowlesi

\section{Geographic Distribution: ${ }^{1}$}

Tropical and subtropical areas

\section{Clinical Features: ${ }^{1,2}$}

Fever, headache, chills, sweating, splenomegaly. Patients can show cyclical patterns of fever and chills being present then absent. In severe malaria, jaundice, shock, bleeding, seizures, or coma may occur. Thrombocytopenia commonly occurs with malarial infections, and may lead to bleeding tendencies.

\section{Hemolysis is mostly intravascular and occurs through a number of different mechanisms: ${ }^{1,2}$}

1. Direct damage to the red blood cells 
2. Immune activation of macrophage activity (Increased extravascular hemolysis)

3. Release of cytokines that inhibit erythropoiesis (inhibit erythropoietin)

4. Increased oxidative stress on RBCs during infection

5. Induction of apoptosis in red blood cell precursors

\section{Laboratory Results for Malarial Infections: ${ }^{1,2}$}

\begin{tabular}{|c|c|c|}
\hline $\begin{array}{l}\text { CBC: } \\
\text { RBC: Decreased } \\
\text { WBC: Normal to Slightly Increased (neutropenia } \\
\text { during chills) } \\
\text { PLT: Decreased } \\
\text { Hct: Decreased } \\
\text { RETIC: Decreased }\end{array}$ & $\begin{array}{l}\text { PBS: } \\
\text { Normochromic } \\
\text { Normocytic } \\
\text { Intracellular Malarial parasite forms (forms and stages of } \\
\text { development seen differ by species) }\end{array}$ & $\begin{array}{l}\text { BM: } \\
\text { Erythroid Hypoplasia }\end{array}$ \\
\hline $\begin{array}{l}\text { Other Tests: } \\
\text { Giemsa stain } \\
\text { Thin Smears: Morphology and parasitemia calculation } \\
\text { Thick Smears: Presence or absence of malaria } \\
\text { Immunoassays } \\
\text { Flow Cytometry } \\
\text { Molecular Testing (PCR) }\end{array}$ & & \\
\hline
\end{tabular}

Note: See "Malaria” under RBC inclusions for additional information.

\section{Babesiosis}

\section{Causative agents: ${ }^{1,3}$}

Babesia microti is carried by the Ixodes scapularis ticks. Babesia can also be transmitted by blood transfusions.

\section{Geographical Distribution: ${ }^{3}$}

Northeast and Midwest United States 


\section{Clinical Features: ${ }^{3}$}

Clinical symptoms include: flu-like symptoms ranging from fever, headache, anorexia, fatigue. Some patients may be asymptomatic. Hepatosplenomegaly may or may not be present.

\section{Laboratory Results for Babesiosis: ${ }^{1,3}$}

\begin{tabular}{lll}
\hline CBC: & PBS: & Other Tests: \\
WBC: Decreased & RBCs shows tetrads of merozoites (Maltese & Hemoglobinuria \\
PLT: Decreased & cross) & Proteinuria \\
Hb: Decreased & & Immunoassays \\
RETIC: Increased & & Molecular testing (PCR)
\end{tabular}

Note: See "Babesia” under Abnormal RBC inclusions for additional information.

\section{Clostridial Sepsis}

\section{Causative agent: ${ }^{1,3}$}

Clostridium perfringens is an anaerobic, gram-positive spore-forming bacilli that can infect tissues after events involving trauma to the body. The bacteria releases enzymes and toxins that damage the surrounding tissue and can allow the bacteria to reach the bloodstream.

Blood infection is often fatal and can lead to massive hemolysis and the activation of DIC.

\section{Mechanism of RBC Destruction: ${ }^{1,3}$}

Hemolysis by C. perfringens is intravascular and can occur due to direct effects of alpha-toxin that it releases on the red blood cell membrane. Cell becomes spherical and subject to osmotic lysis. Significant intravascular hemolysis ensues, leading to a marked decrease in hematocrit, and dark red/brown plasma and urine. 
CBC:

RBC: Decreased

PLT: Decreased

Hct: Very Decreased

\section{PBS:}

Spherocytes

Microcytes

Ghost cells

Toxic changes with a left shift

+/- ingested bacteria within neutrophils
Other Tests:

Hemoglobinemia

Hemoglobinuria

\section{References:}

1. Harmening DM, Yang D, Zeringer H. Hemolytic anemias: extracorpuscular defects. 5th ed. Philadelphia: F.A. Davis Company; 2009. p. 250-79).

2. Akinosoglou KS, Solomou EE, Gogos CA. Malaria: a haematological disease. Hematology [Internet]. 2012 Mar 1 [cited 2018 Jul 9];17(2):106-14. Available from: http://www.tandfonline.com/doi/full/10.1179/102453312X13221316477336

3. Keohane EM. Extrinsic defects leading to increased erythrocyte destruction - nonimmune causes. In: Rodak's hematology clinical applications and principles. 5th ed. St. Louis, Missouri: Saunders; 2015. p. 394-410. 
IX

RED BLOOD CELLS: INTRINSIC DEFECTS OF THE RBC MEMBRANE CAUSING HEMOLYTIC ANEMIA 


\section{8 \\ Hereditary Spherocytosis}

\section{MICHELLE TO AND VALENTIN VILLATORO}

An interactive or media element has been excluded from this version of the text. You can view it online here: https://pressbooks.library.ualberta.ca/mlsci/?p=547

Images of hereditary spherocytosis peripheral blood smears demonstrating marked spherocytosis and polychromasia. From MLS Collection, University of Alberta.

Image 1: 100x oil immersion. https://doi.org/10.7939/R34B2XK9F

Image 2: 50 x oil immersion. https://doi.org/10.7939/R3HM53096

\section{Note:}

The hereditary condition results in the formation of spherocytes with a decreased life span, decreased deformability, and a reduced surface-to-volume ratio causing increased osmotic fragility. ${ }^{1}$

\section{Mutation:}

Genetic mutations in the vertical protein linkages between the membrane and cytoskeleton: $\alpha$-spectrin, $\beta$-spectrin, band 3, ankyrin, and protein $4.2 \cdot{ }^{1-4}$ Results in loss of unsupported membrane overtime, and spherocyte formation.

\section{Inheritance: ${ }^{1,3}$}

Autosomal dominant or recessive depending on which mutations are inherited. 


\section{Clinical Features: ${ }^{1,3,4}$}

Jaundice

Fatigue

Pallor

Splenomegaly

Iron Overload

Extramedullary erythropoiesis

\section{Laboratory Results: ${ }^{1-3}$}

\section{CBC:}

Hb: Decreased

MCV: Decreased to Normal

$\mathrm{MCH}$ : Normal to Increased

MCHC: Increased

(>360 g/L)

RETIC: Increased

RDW: Increased

\section{PBS:}

Spherocytes (Variable amounts) Polychromasia

Increased inclusions (HJ bodies,

pappenheimer bodies)

+/- NRBCs

\section{BM:}

M:E Ratio: Decreased

Erythroid Hyperplasia

\section{Other Tests:}

Osmotic Fragility: Increased

Eosin -5'-maleimide Binding Test: Decreased fluorescence

DAT: Negative (AIHA with spherocytes are DAT positive)

Markers of EVH:

Bilirubin: Increased

LD: Increased

Urobilinogen: Increased 


\section{References:}

1. Gallagher PG. Abnormalities of the erythrocyte membrane. Pediatr Clin North Am [Internet]. 2013 Dec 15 [cited 2018 Jun 26];60(6):1349-62. Available from: http://www.ncbi.nlm.nih.gov/pmc/articles/PMC4155395/

2. Keohane EM. Intrinsic defects leading to increased erythrocyte destruction. In: Rodak's hematology clinical applications and principles. 5th ed. St. Louis, Missouri: Saunders; 2015. p. 367-93.

3. Andolfo I, Russo R, Gambale A, Iolascon A. New insights on hereditary erythrocyte membrane defects. Haematologica [Internet]. 2016 Nov 22 [cited 2018 Jun 26];101(11):1284-94. Available from: http://www.ncbi.nlm.nih.gov/pmc/articles/PMC5394881/

4. Da Costa L, Galimand J, Fenneteau O, Mohandas N. Hereditary spherocytosis, elliptocytosis, and other red cell membrane disorders. Blood Rev [Internet]. 2013[cited 2018 Jul 24];27(4):167-78. Available from: http://www.sciencedirect.com/science/article/pii/S0268960X13000192 


\title{
49
}

\section{Hereditary Elliptocytosis \& Related Variants}

\author{
MICHELLE TO AND VALENTIN VILLATORO
}

\section{Hereditary Elliptocytosis}

An interactive or media element has been excluded from this version of the text. You can view it online here:

https://pressbooks.library.ualberta.ca/mlsci/?p=557

Images of hereditary elliptocytosis peripheral blood smears showing numerous elliptocytes. From MLS Collection, University of Alberta.

Image 1: 100x oil immersion. https://doi.org/10.7939/R3F18SW6B

Image 2: 100x oil immersion. https://doi.org/10.7939/R3JS9HQ0S

Hereditary elliptocytosis encompasses group of hereditary conditions that result in the formation of elliptocytes with a decreased erythrocyte lifespan. ${ }^{1}$ Variants of hereditary elliptocytosis include Hereditary pyropoikilocytosis and Southeast Asian Ovalocytosis.

\section{Mutation:}

Genetic mutations involving the horizontal protein linkages between the membrane and cytoskeleton: $\alpha$ spectrin, $\beta$-spectrin, protein 4.1, glycophorin C) ${ }^{2-4}$ These mutations result in a decreased red blood cell lifespan and increased susceptibility to hemolysis (primarily extravascular). Hemolysis is often mild. 
Inheritance: ${ }^{1,3,4}$

Autosomal dominant

\section{Clinical Features:}

Patients are usually asymptomatic and discovery of hereditary elliptocytosis is often incidental. ${ }^{1,3}$

\section{Laboratory Results for Hereditary Elliptocytosis: ${ }^{1,5}$}

\begin{tabular}{lll}
\hline CBC: & PBS: & Other Tests: \\
MCV: Normal to Increased & Elliptocytes (Variable amounts) & Osmotic Fragility: Normal \\
MCH, MCHC: Normal & During hemolytic episodes may see: & Thermal Stability: Decreased \\
& Normocytic, normochromic anemia & PCR \\
& Increased Polychromasia & Hyperbilirubinemia \\
& & LDH: Increased
\end{tabular}

\section{Hereditary Pyropoikilocytosis (HPP)}

A rare variant of hereditary elliptocytosis that presents with severe hemolytic anemia., ${ }^{4,5}$

Inheritance: $:^{2,4}$

Autosomal recessive

Mutation: ${ }^{2,4}$

Defects in spectrin that results in red blood cell fragmentation. 


\section{Laboratory Findings for HPP: $:^{2,4,5}$}

CBC:

RBC: Decreased

$\mathrm{Hb}$ : Decreased

MCV: Always decreased

MCHC: Increased
PBS:

Microspherocytes

Schistocytes

Elliptocytes

\section{Other Tests:}

Osmotic Fragility: Increased

Thermal Sensitivity: Increased

Eosin -5'-maleimide Binding Test:

Decreased fluorescence

\section{Southeast Asian Ovalocytosis (SA0)}

A variant of hereditary elliptocytosis that and clinical symptoms are mainly asymptomatic. Ovalocytes are large and may show one or more transverse bars in the cytoplasm of the cell. These ovalycotes are much more rigid than normal red blood cells. ${ }^{5}$ Patients are usually asymptomatic. ${ }^{2}$

\section{Inheritance: ${ }^{2-4}$}

Autosomal dominant

\section{Mutation: $:^{2,3}$}

Mutation in the Band 3 protein.

\section{Laboratory Findings for SAO: ${ }^{5}$}

PBS: Elliptocytes (May show one or more transverse bars) 


\section{References:}

1. Gallagher PG. Abnormalities of the erythrocyte membrane. Pediatr Clin North Am [Internet]. 2013 Dec 15 [cited 2018 Jun 26];60(6):1349-62. Available from: http://www.ncbi.nlm.nih.gov/pmc/articles/PMC4155395/

2. Keohane EM. Intrinsic defects leading to increased erythrocyte destruction. In: Rodak's hematology clinical applications and principles. 5th ed. St. Louis, Missouri: Saunders; 2015. p. 367-93.

3. Da Costa L, Galimand J, Fenneteau O, Mohandas N. Hereditary spherocytosis, elliptocytosis, and other red cell membrane disorders. Blood Rev [Internet]. 2013[cited 2018 Jul 24];27(4):167-78. Available from: http://www.sciencedirect.com/science/article/pii/S0268960X13000192

4. Andolfo I, Russo R, Gambale A, Iolascon A. New insights on hereditary erythrocyte membrane defects. Haematologica [Internet]. 2016 Nov 22 [cited 2018 Jun 26];101(11):1284-94. Available from: http://www.ncbi.nlm.nih.gov/pmc/articles/PMC5394881/

5. Coetzer T, Zail S. Hereditary defects of the red cell membrane. 5th ed. Philadelphia: F.A. Davis Company; 2009. p. 176-95). 


\section{0}

Hereditary Stomatocytosis Syndromes

MICHELLE TO AND VALENTIN VILLATORO

\section{Overhydrated Hereditary Stomatocytosis}

Condition results in cells with altered intracellular concentrations of sodium $(\mathrm{Na}+)$ and potassium $(\mathrm{K}+)$ ions. There is an increased permeability of $\mathrm{K}+$ into the cell and increased permeability of $\mathrm{Na}+$ out of the cell. This results in cells with increased volume (cells are overhydrated), a decreased surface-to-volume ratio, and decreased cytoplasm viscosity. ${ }^{1-3}$

\section{Mutation: ${ }^{1,3}$}

Hereditary defect leading to alterations in the permeability of the red blood cell membrane.

\section{Inheritance: ${ }^{1-3}$}

Autosomal dominant (Severe hemolysis may indicate a autosomal recessive inheritance)

\section{Laboratory Results: ${ }^{1-3}$}

CBC:

MCV: Increased

MCHC: Decreased
PBS:

Macorcytes

Stomatocytes
Other Tests:

Osmotic Fragility: Increased 


\section{Dehydrated Hereditary Stomatocytosis (Hereditary Xerocytosis)}

Defects lead to an increased movement of $\mathrm{K}+$ out of the cell and results in the dehydration of cell. Unlike Stomatocytes, cells have an increased surface-to-volume ratio. ${ }^{2}$

\section{Inheritance: $:^{2-4}$}

Autosomal dominant

\section{Laboratory Results: ${ }^{1-4}$}

\begin{tabular}{lll}
\hline CBC: & PBS: & Other Tests: \\
MCV: Increased & Stomatocytes & Osmotic Fragility: Increased \\
MCHC: Increased & Target cells & \\
& Echinocytes & \\
& Macrocytes & \\
& RBCs with Hb concentrated at the periphery of & \\
& the cell & \\
\hline
\end{tabular}

\section{References:}

1. Keohane EM. Intrinsic defects leading to increased erythrocyte destruction. In: Rodak's hematology clinical applications and principles. 5th ed. St. Louis, Missouri: Saunders; 2015. p. 367-93.

2. Coetzer T, Zail S. Hereditary defects of the red cell membrane. 5th ed. Philadelphia: F.A. Davis Company; 2009. p. 176-95).

3. Da Costa L, Galimand J, Fenneteau O, Mohandas N. Hereditary spherocytosis, elliptocytosis, and other red cell membrane disorders. Blood Rev [Internet]. 2013[cited 2018 Jul 24];27(4):167-78. Available from: http://www.sciencedirect.com/science/article/pii/S0268960X13000192

4. Andolfo I, Russo R, Gambale A, Iolascon A. New insights on hereditary erythrocyte membrane defects. Haematologica [Internet]. 2016 Nov 22 [cited 2018 Jun 26];101(11):1284-94. Available from: 
http://www.ncbi.nlm.nih.gov/pmc/articles/PMC5394881/ 


\section{1}

\section{Hereditary Acanthocytosis (Abetalipoproteinemia)}

\section{MICHELLE TO AND VALENTIN VILLATORO}

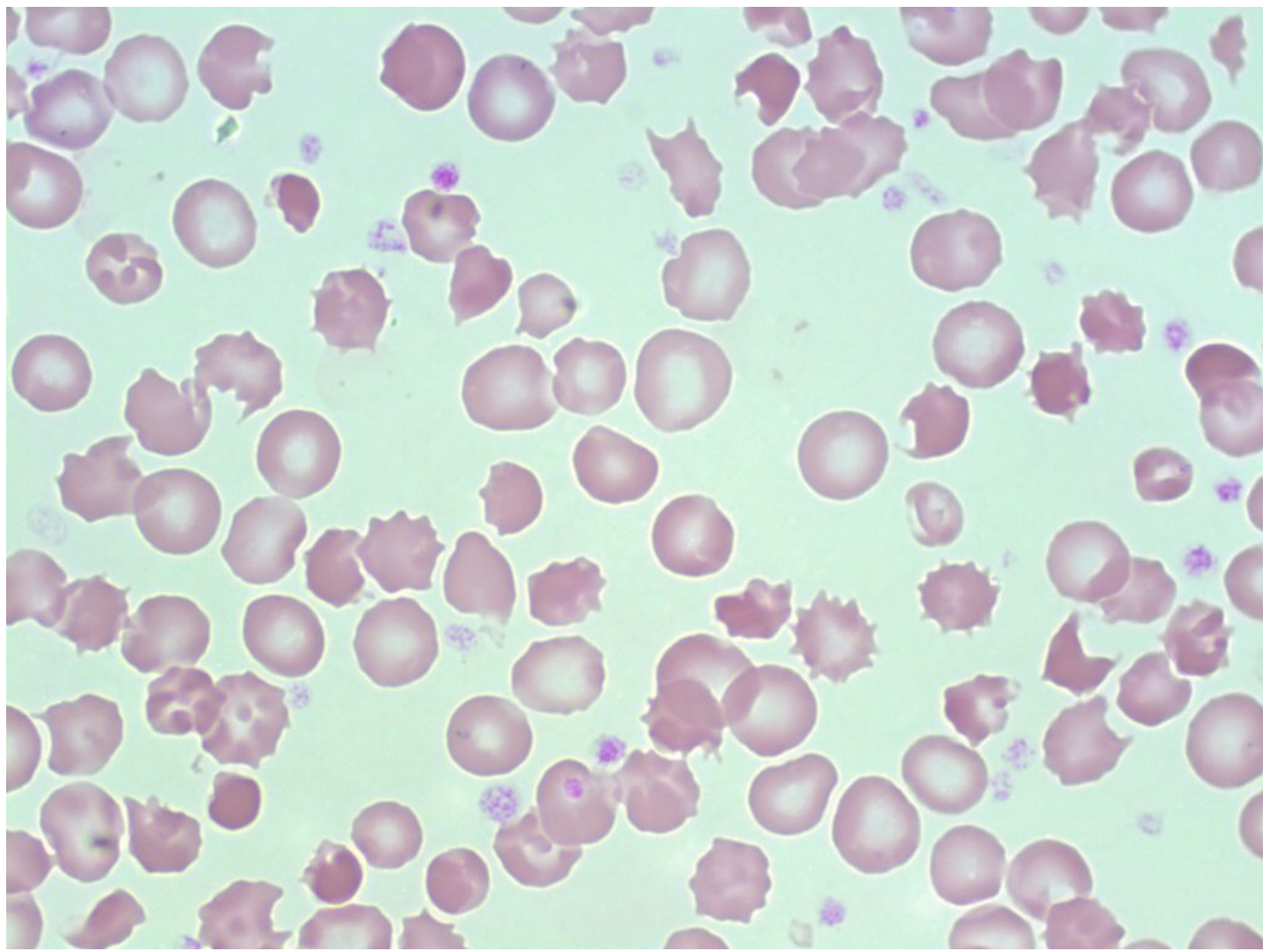

An image from a peripheral blood smear showing acanthocytes and other poikilocytosis. Hereditary acanthocytosis would typically show acanthocytes as the main red blood cell abnormality. From MLS Collection, University of Alberta, https://doi.org/10.7939/R31J97P8T 
Microsomal triglyceride transfer protein (MTP) gene mutation that results in a lack of apolipoprotein B. An increase in sphingomyelin concentration in the RBC membrane leads to increased membrane rigidity and acanthocyte formation.

\section{Inheritance:', ${ }^{1,2}$}

Autosomal recessive

\section{Laboratory Results: ${ }^{1,2}$}

CBC:

MCV: Normal

$\mathrm{MCH}$ : Normal

MCHC: Normal

RETIC: Normal to increased
PBS:

Acanthocytes

\section{Hereditary Acanthocytosis References:}

1. Cochran-Black D. Hemolytic anemia: membrane defects. In: Clinical laboratory hematology. 3rd ed. New Jersey: Pearson; 2015. p. 317-33.

2. Keohane EM. Intrinsic defects leading to increased erythrocyte destruction. In: Rodak's hematology clinical applications and principles. 5th ed. St. Louis, Missouri: Saunders; 2015. p. 367-93. 


\section{2}

\section{Paroxysmal Nocturnal Hemoglobinuria $(\mathrm{PNH})$}

\section{MICHELLE TO AND VALENTIN VILLATORO}

Paroxysmal Nocturnal Hemoglobinuria is an acquired clonal disorder that starts at the stem cell level. Cells produced become susceptible and are destroyed by chronic complement-mediated hemolysis. ${ }^{1,2}$

\section{Cause(s): ${ }^{1,2}$}

Deficiency in glycosylphosphatidylinositol anchor proteins (GPIs). Normally, CD55 and CD59 act as complement regulators to prevent autologous complement-mediated hemolysis. Without GPIs, cells lack CD55 and CD59 and undergo spontaneous intravascular hemolysis.

Hemolytic episodes (Paroxysms) can be exacerbated by stressors such as inflammation or infections.

\section{Complications: ${ }^{2}$}

Hemolytic Anemia

Bone Marrow Failure

Thrombophilia

Laboratory Results for PNH: ${ }^{1,3,4}$ 


\begin{tabular}{|c|c|c|}
\hline CBC: & PBS: & BM: \\
\hline RBC: Decreased & May see: & If BM Failure: \\
\hline WBC: Decreased & $-n R B C s$ & -Impaired hematopoiesis \\
\hline PLT: Decreased & -Polychromasia & -Hypocellular \\
\hline \multirow{7}{*}{$\begin{array}{l}\text { Hb: Decreased } \\
\text { MCV: Increased } \\
\text { RETIC: Increased }\end{array}$} & & \\
\hline & If Iron Deficiency Present: & If not BM Failure, may be: \\
\hline & -Hypochromic & -Normo to hypercellular \\
\hline & -Microcytic & -Erythroid hyperplasia \\
\hline & If Folate Deficiency Present: & Iron stores: Decreased, or absent \\
\hline & -Oval Macrocytes & Note: Any dysplastic findings may be indicative of MDS. \\
\hline & $\begin{array}{l}\text { If BM Failure Present: } \\
\text {-Pancytopenia }\end{array}$ & \\
\hline Iron Studies: & Other Tests: & Tests for IVH: \\
\hline Same as iron deficiency anemia if patient & Sucrose Hemolysis Test: Positive for hemolysis & Indirect bilirubin: Increased \\
\hline becomes iron deficient. & Ham's (Acidified Serum Lysis) Test: Positive & Haptoglobin: Decreased \\
\hline & Flow cytometry (for CD55 and CD59) & LD: Increased \\
\hline & DAT: Negative & Hemoglobinemia \\
\hline & Osmotic Fragility: Normal & Hemoglobinuria \\
\hline & & Hemosiderinuria \\
\hline
\end{tabular}

\section{References:}

1. DeZern AE, Brodsky RA. Paroxysmal Nocturnal Hemoglobinuria. A Complement-Mediated Hemolytic Anemia. Hematol Oncol Clin North Am [Internet]. 2015 Jun 7 [cited 2018 Jun 26];29(3):479-94. Available from: http://www.ncbi.nlm.nih.gov/pmc/articles/PMC4695989/

2. Mastellos DC, Ricklin D, Yancopoulou D, Risitano A, Lambris JD. Complement in paroxysmal nocturnal hemoglobinuria: Exploiting our current knowledge to improve the treatment landscape. Expert Rev Hematol [Internet]. 2014 Oct 2 [cited 2018 Jun 26];7(5):583-98. Available from: http://www.ncbi.nlm.nih.gov/pmc/articles/PMC4383744/

3. Cochran-Black D. Hemolytic anemia: membrane defects. In: Clinical laboratory hematology. 3rd ed. New Jersey: Pearson; 2015. p. 317-33.

4. Keohane EM. Intrinsic defects leading to increased erythrocyte destruction. In: Rodak's hematology clinical applications and principles. 5th ed. St. Louis, Missouri: Saunders; 2015. p. 367-93. 


\section{3}

\section{Glucose-6-phosphate Dehydrogenase \\ (G6PD) Deficiency}

MICHELLE TO AND VALENTIN VILLATORO

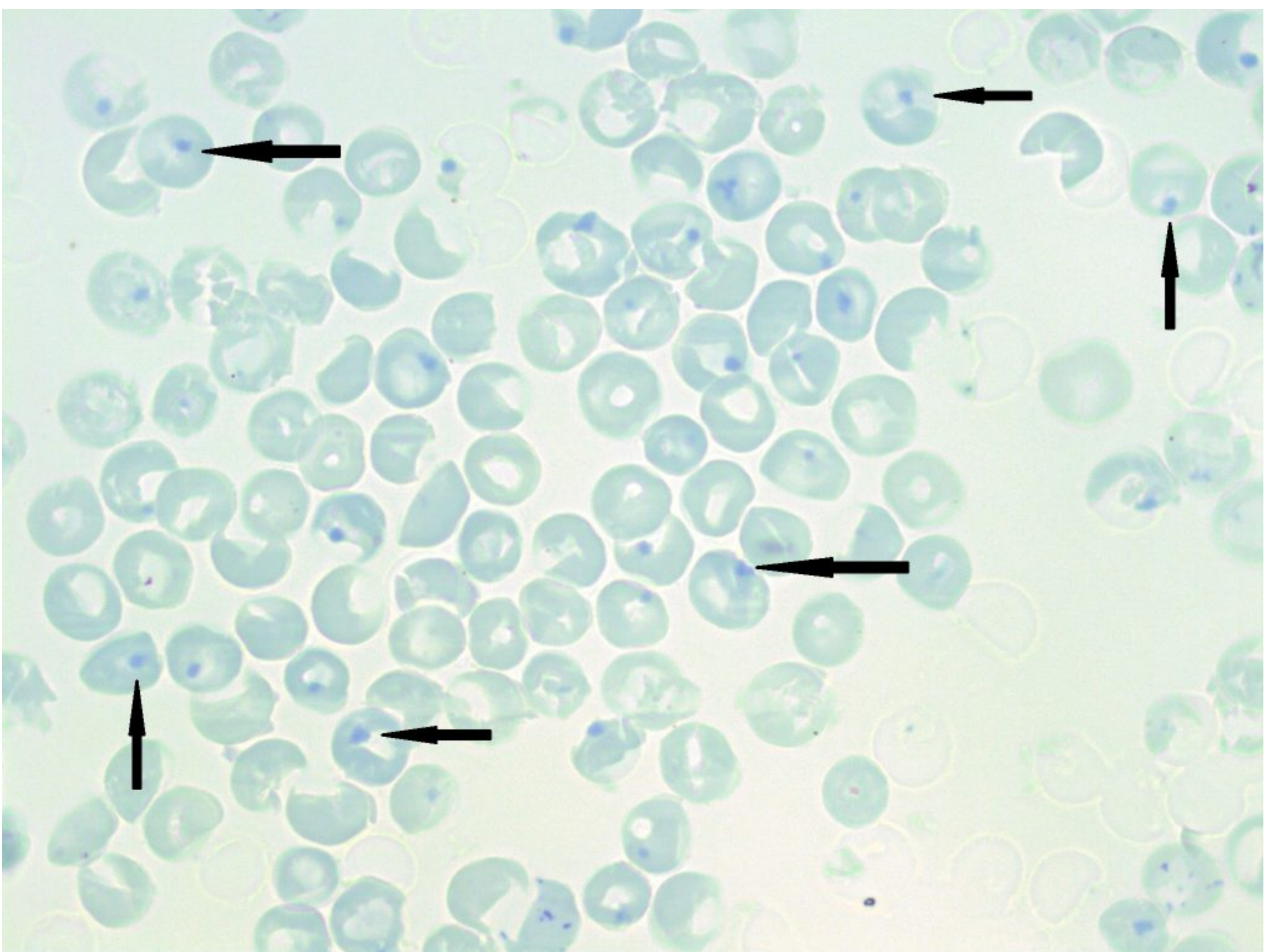

A peripheral blood smear stained with a supravital stain demonstrating numerous heinz bodies (indicated by arrows). 100x oil immersion. From MLS Collection, University of Alberta, https://doi.org/10.7939/R35718396

Normal G6PD Function: Hexose Monophosphate (HMP) Shunt and Oxidative Damage ${ }^{1,2}$ 
The HMP Shunt describes the glycolytic pathway where glucose is transferred to and catabolized in the cell to produce ATP and maintain sustainable amounts of reduced glutathione (GSH). GSH acts to protect the red blood cell from oxidative damage by reducing oxidative molecules (Peroxides and free oxygen radicals) and becoming oxidized itself.

In the HMP shunt, NADPH is generated by G6PD from NADP which than acts to regenerate reduced glutathione from its oxidized state to allow continued protection from oxidative damage. A lack of G6PD results in increased red blood cell destruction.

G6PD activity is highest in younger cells (i.e. reticulocytes) compared to that of older and more mature red blood cells. ${ }^{1}$

\section{Mutation: ${ }^{2}$}

G6PD gene mutation results in decreased G6PD levels.

\section{Inheritance: ${ }^{1}$}

X-linked

\section{Complications: ${ }^{1,2}$}

Acute hemolytic Anemia

Neonatal Hyperbilirubinemia

Chronic Nonspherocytic Hemolytic Anemia

\section{Causes of Hemolytic Episodes: ${ }^{1,2}$}

Exposure to oxidative agents:

-Drugs (e.g. antimalarials, sulfonamides) 
-Infections

-Fava Beans (Favism)

\section{Notes:}

G6PD deficiency is commonly associated with bite and blister cells. Oxidized hemoglobins become denatured and form heinz bodies within the red blood cells. These heinz bodies can be removed by splenic macrophages through a "pitting" mechanism, which results in the formation of bite and blister cells. ${ }^{1}$

It has been suggested that G6PD deficiency acts as a protective mechanism from malaria as the prevalence of G6PD deficiency coincides with that of malaria. ${ }^{1}$

\section{Laboratory Results for G6PD Deficiency: ${ }^{1}$}

\section{CBC:}

WBC: Increased

PLT: Normal

Hb: Decreased

MCHC: Increased

RETIC: Increased

\section{PBS:}

Bite and Blister Cells

Polychromasia

Occasional spherocytes

Heinz bodies (Supravital staining)

\section{Other Tests:}

Dye Reduction Test: No colour change

G6PD Assay: Decreased activity

DAT: Negative

Hemolysis Markers:

Indirect Bilirubin: Increased

LDH: Increased

Haptoglobin: Decreased

Hemoglobinemia

Hemoglobinuria

\section{References:}

1. Lake M, Bessmer D. Hemolytic anemia: enzyme deficiencies. In: Clinical laboratory hematology. 3rd ed. New Jersey: Pearson; 2015. p. 334-47.

2. Keohane EM. Intrinsic defects leading to increased erythrocyte destruction. In: Rodak's hematology clinical applications and principles. 5th ed. St. Louis, Missouri: Saunders; 2015. p. 367-93. 
54

Pyruvate Kinase (PK) Deficiency

\section{MICHELLE TO AND VALENTIN VILLATORO}

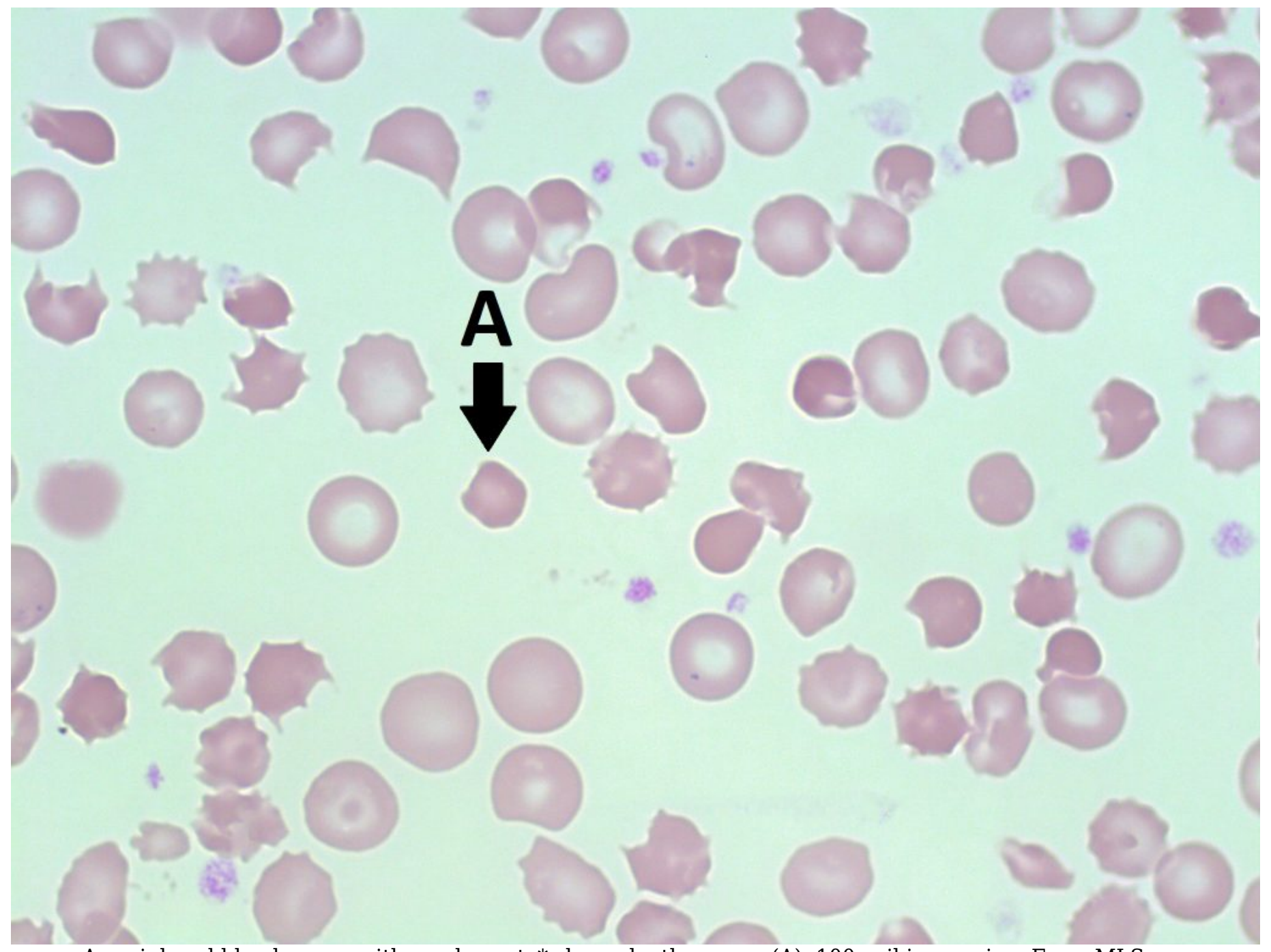

A peripheral blood smear with a pyknocyte* shown by the arrow (A). 100x oil immersion. From MLS Collection, University of Alberta, https://doi.org/10.7939/R3VX06J4H

\section{Normal PK Function:}

Pyruvate Kinase catalyzes the conversion of phosphoenolpyruvate to pyruvate which results in the production of ATP from ADP. A lack of pyruvate kinase results in the ability of cells to maintain proper 
cell shape, normal lifespan, and low levels of 2,3-PBG. ${ }^{1,2}$

Mutation: ${ }^{1,2}$

Mutations in the PKLR gene leading to decreased levels of pyruvate kinase.

Inheritance: ${ }^{1,2}$

Autosomal recessive

Complications: ${ }^{1,2}$

Chronic hemolytic anemia

Splenomegaly

Jaundice

Gallstones

Notes: ${ }^{1}$

WBCs contain more pyruvate kinase than RBCs.

\section{Laboratory Results for PK Deficiency: ${ }^{1}$}

\begin{tabular}{l}
\hline CBC: \\
Hb: Decreased \\
RETIC: Increased \\
*Note: The term "pyknocyte" is not \\
universally used. It refers to a small, \\
dehydrated, dark-colored RBC.
\end{tabular}




\section{References:}

1. Lake M, Bessmer D. Hemolytic anemia: enzyme deficiencies. In: Clinical laboratory hematology. 3rd ed. New Jersey: Pearson; 2015. p. 334-47.

2. Keohane EM. Intrinsic defects leading to increased erythrocyte destruction. In: Rodak's hematology clinical applications and principles. 5th ed. St. Louis, Missouri: Saunders; 2015. p. 367-93. 


\section{$\mathrm{X}$ \\ WHITE BLOOD CELLS AND PLATELETS: NORMAL MORPHOLOGY}




\section{5 \\ Granulocytes and \\ Granulocyte Maturation}

MICHELLE TO AND VALENTIN VILLATORO

Myeloblast/Blast

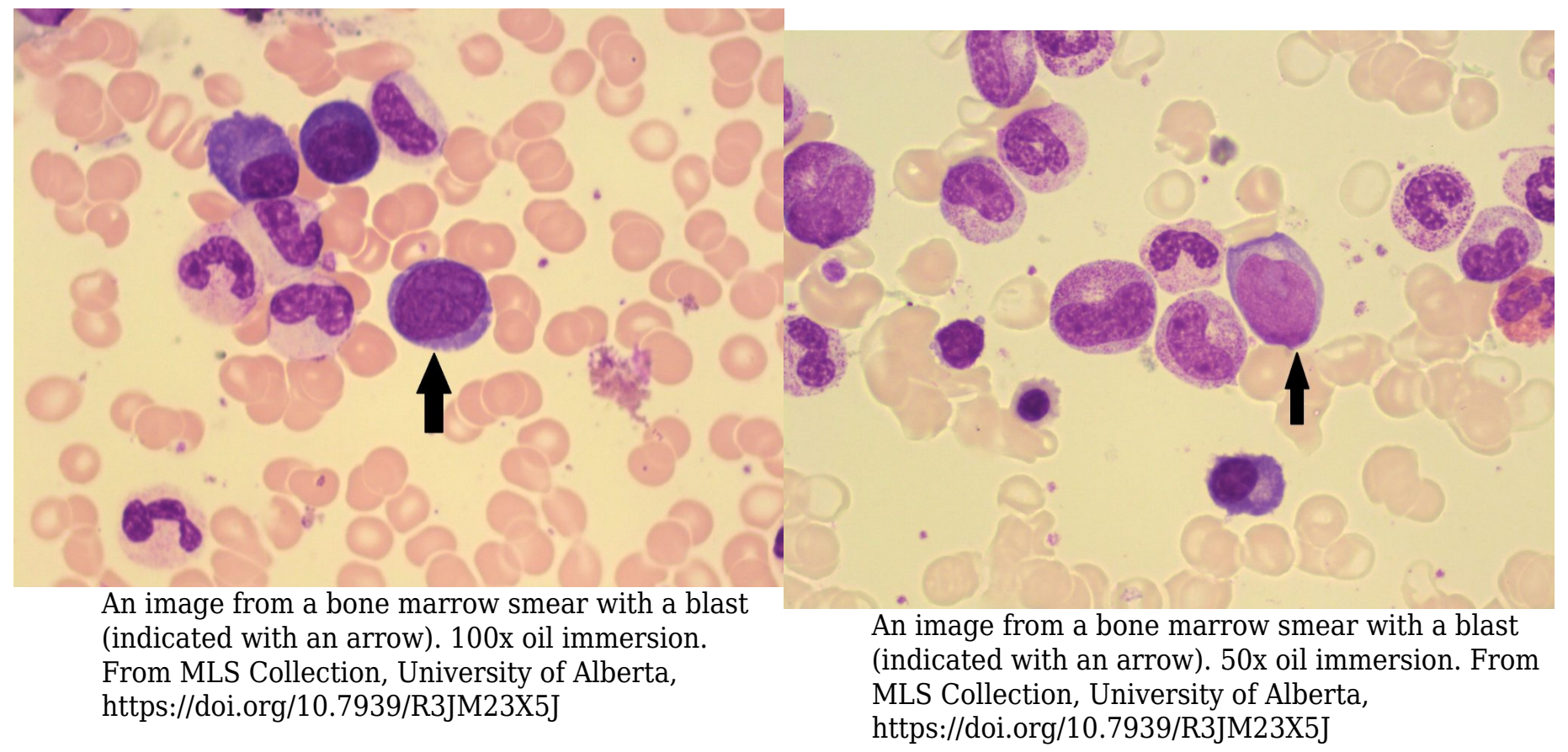

Notes: Earliest distinguishable and recognizable stage of granulocyte maturation. ${ }^{1}$

Nucleus-to-Cytoplasm Ratio: $4: 1^{2}$ 
Nucleoli: $1-5^{1}$

\section{Nucleus: ${ }^{1,3}$}

Round to oval

Central or eccentrically located

Loose, open, evenly stained, reddish-purple, chromatin

\section{Cytoplasm: ${ }^{1,2}$}

Dark to light basophilia

May contain granules (up to 20)

Golgi may be seen (pale area next to the nucleus)

Normal \% in Bone Marrow: 0-2\% ${ }^{2}$

Normal \% in Peripheral Blood: $0 \%^{2}$

\section{Promyelocyte}




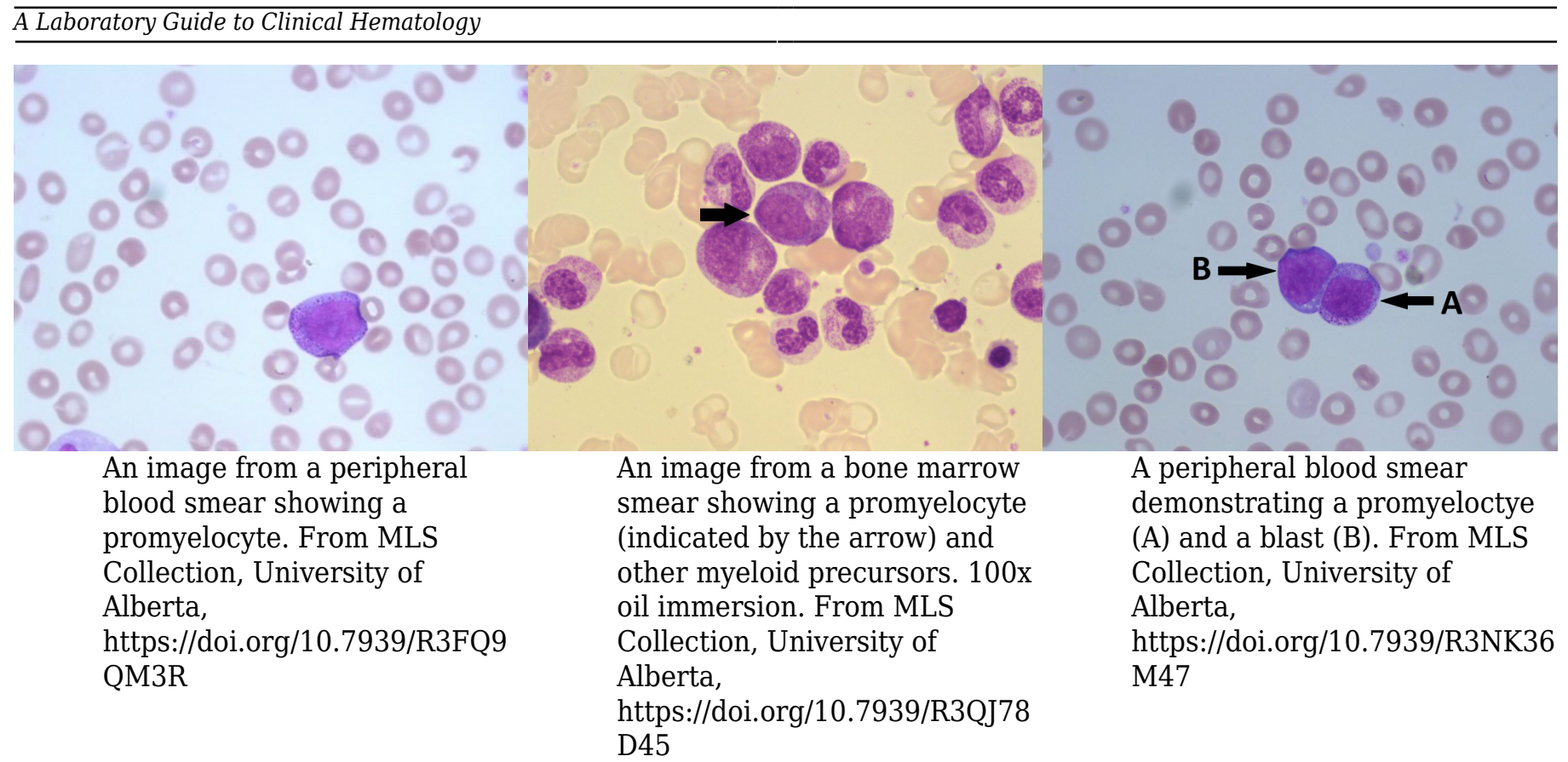

Notes: Presence of primary granules marks maturation at the promyelocyte stage. ${ }^{3}$

Nucleus-to-Cytoplasm Ratio: $3: 1^{2}$

Nucleoli: $1-3^{2}$

Nucleus: $:^{1-3}$

Round to oval

Central or eccentrically located

Reddish-blue chromatin

Fine and slightly coarser chromatin than a myeloblast

\section{Cytoplasm: ${ }^{2}$}


Lightly basophilic

Primary (fine, nonspecific) granules present (reddish-purple)

Normal \% in Bone Marrow: $2-5 \%^{2}$

Normal \% in Peripheral Blood: $0 \%^{2}$

\section{Myelocyte}

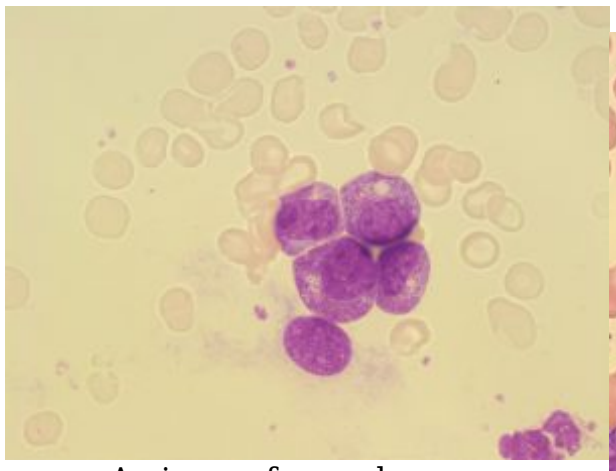

An image from a bone marrow smear showing four myelocytes (center) with both primary and secondary granules. 100x oil immersion. From MLS Collection, University of Alberta, https://doi.org/10.7939/R3V980 69S

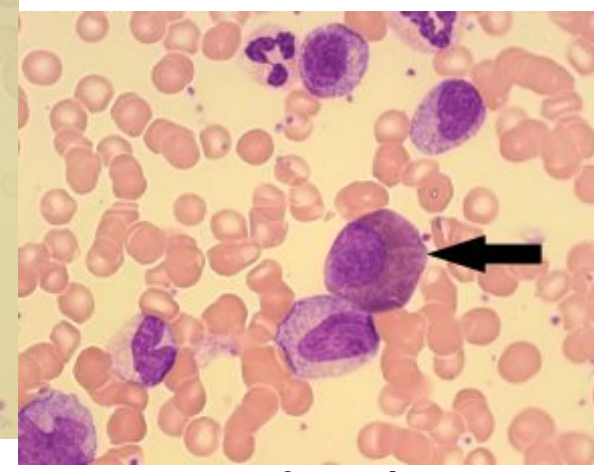

An image from a bone marrow smearing showing a eosinophilic myelocyte (indicated by the arrow). A neutrophil myelocyte is below the eosinophil myelocyte. From MLS Collection, University of Alberta, https://doi.org/10.7939/R36M33 KOX

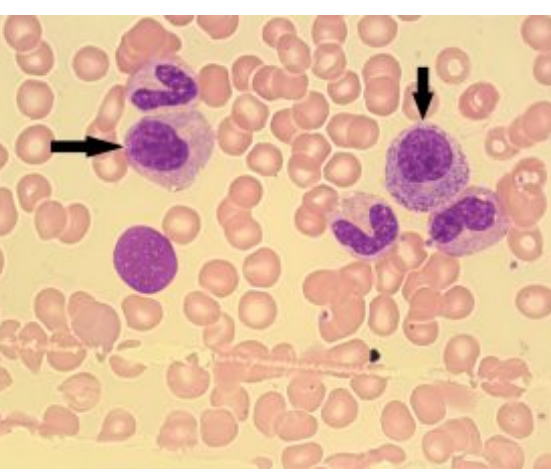

An image of a bone marrow smear with myeloid precursors. Myelocytes are indicated with arrows. 100x oil immersion. From MLS Collection, University of Alberta, https://doi.org/10.7939/R3BC3T C4P

Notes: Presence of secondary granules marks maturation at the myelocyte stage. Primary granules may still be seen but decrease in number as the cell matures. Secondary granules become more predominant as the cell mature and are considered specific to a granulocytic lineage. ${ }^{1}$ 
The myelocyte is the last stage where the cell is able to undergo mitosis. ${ }^{1}$

Nucleus-to-Cytoplasm Ratio: $2: 1^{2}$

Nucleoli: Usually not visible ${ }^{2}$

\section{Nucleus: $:^{2,3}$}

Round to oval

Eccentrically located

Reddish-purple, slightly clumped chromatin

\section{Cytoplasm: $:^{2-5}$}

Primary granules may be present in small amounts (Decrease in number as the cell matures).

Secondary (coarse, specific) granules present (Increase in number as the cell matures).

\begin{tabular}{ccc}
\hline Granulocyte & Cytoplasm Colour & Secondary (Coarse, Specific) Granule Colour \\
Neutrophil & pink-tan & azurophilic (reddish-purple) \\
Eosinophil & cream coloured to colourless & eosinophilic (Pale to dark orange) \\
Basophil & pale blue & basophilic (dark purple-black) \\
\hline
\end{tabular}

Normal \% in the Bone Marrow and Peripheral Blood: ${ }^{2,4,5}$

\begin{tabular}{cll}
\hline Granulocyte & \% In Bone Marrow & \% In Peripheral Blood \\
Neutrophil & $5-19 \%$ & $0 \%$ \\
Eosinophil & $0-2 \%$ & $0 \%$ \\
Basophil & $0-1 \%$ & N/A \\
\hline
\end{tabular}




\section{Metamyelocyte}

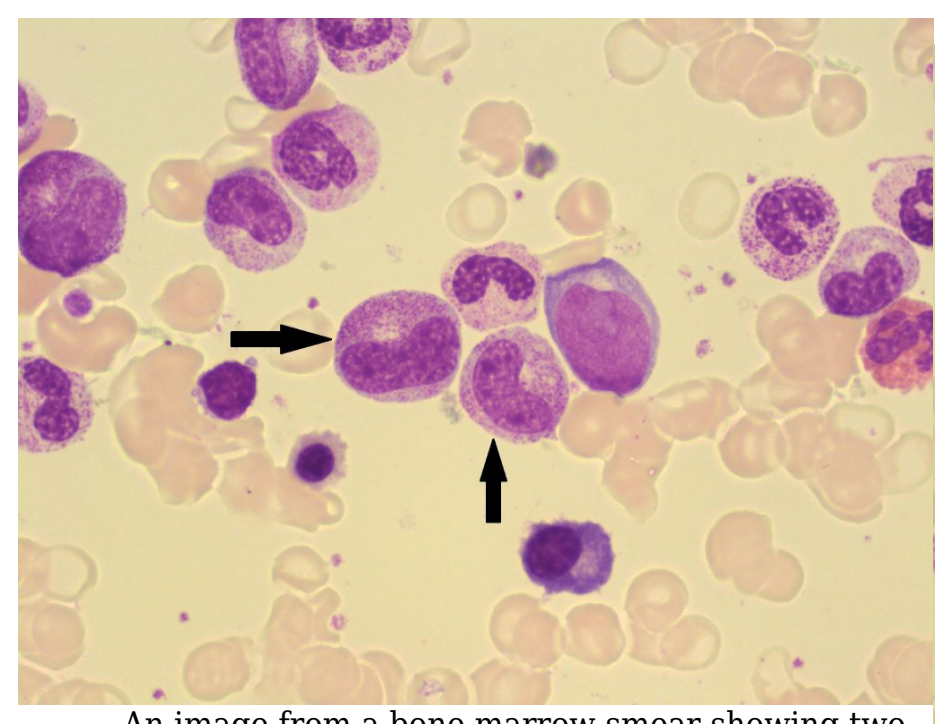

An image from a bone marrow smear showing two metamyelocytes (indicated with arrows). 50x oil immersion. From MLS Collection, University of Alberta, https://doi.org/10.7939/R30863M9J

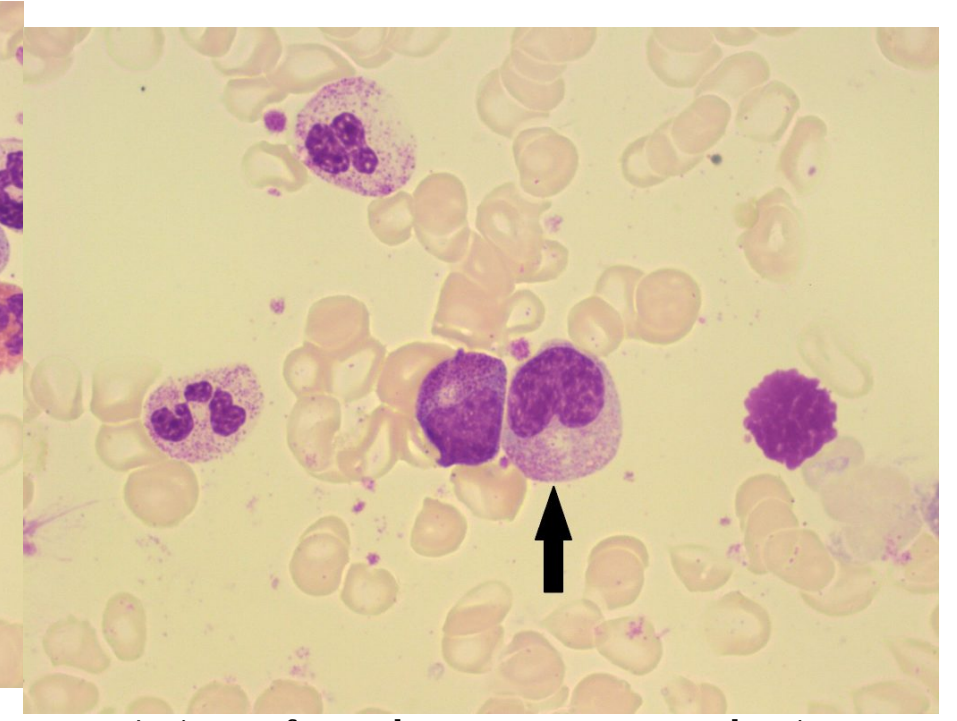

An image from a bone marrow smear showing a metamyelocyte (indicated with an arrow). A myelocyte is present on the left of the metameylocyte. 100x oil immersion. From MLS Collection, University of Alberta, https://doi.org/10.7939/R33T9DN6V

Notes: Cell is no longer capable of mitosis at this stage. Characteristic feature of a metamyelocyte is the indented nucleus shape (nucleus looks as if it was lightly poked). ${ }^{1}$

Nucleus-to-Cytoplasm Ratio: $1.5: 1^{2}$

Nucleoli: Not visible ${ }^{2}$

Nucleus: $:^{1-3}$ 
Indented (kidney bean shaped); indent is less than one-third of the diameter of the hypothetical round nucleus

Eccentrically located

Dark purple, coarse, clumped chromatin

\section{Cytoplasm: ${ }^{2-5}$}

Granulocyte

Neutrophil

Eosinophil

Basophil
Cytoplasm Colour

pink-tan

cream coloured to colourless

pale blue
Secondary (Coarse, Specific) Granule Colour

azurophilic (reddish-purple)

eosinophilic (Pale to dark orange)

basophilic (dark purple-black)

Normal \% in the Bone Marrow and Peripheral Blood: ${ }^{2-5}$

\begin{tabular}{cll}
\hline Granulocyte & \% In Bone Marrow & \% In Peripheral Blood \\
Neutrophil & $3-22 \%$ & $0 \%$ \\
Eosinophil & $0-2 \%$ & $0 \%$ \\
Basophil & $0-1 \%$ & N/A \\
\hline
\end{tabular}

\section{Band}




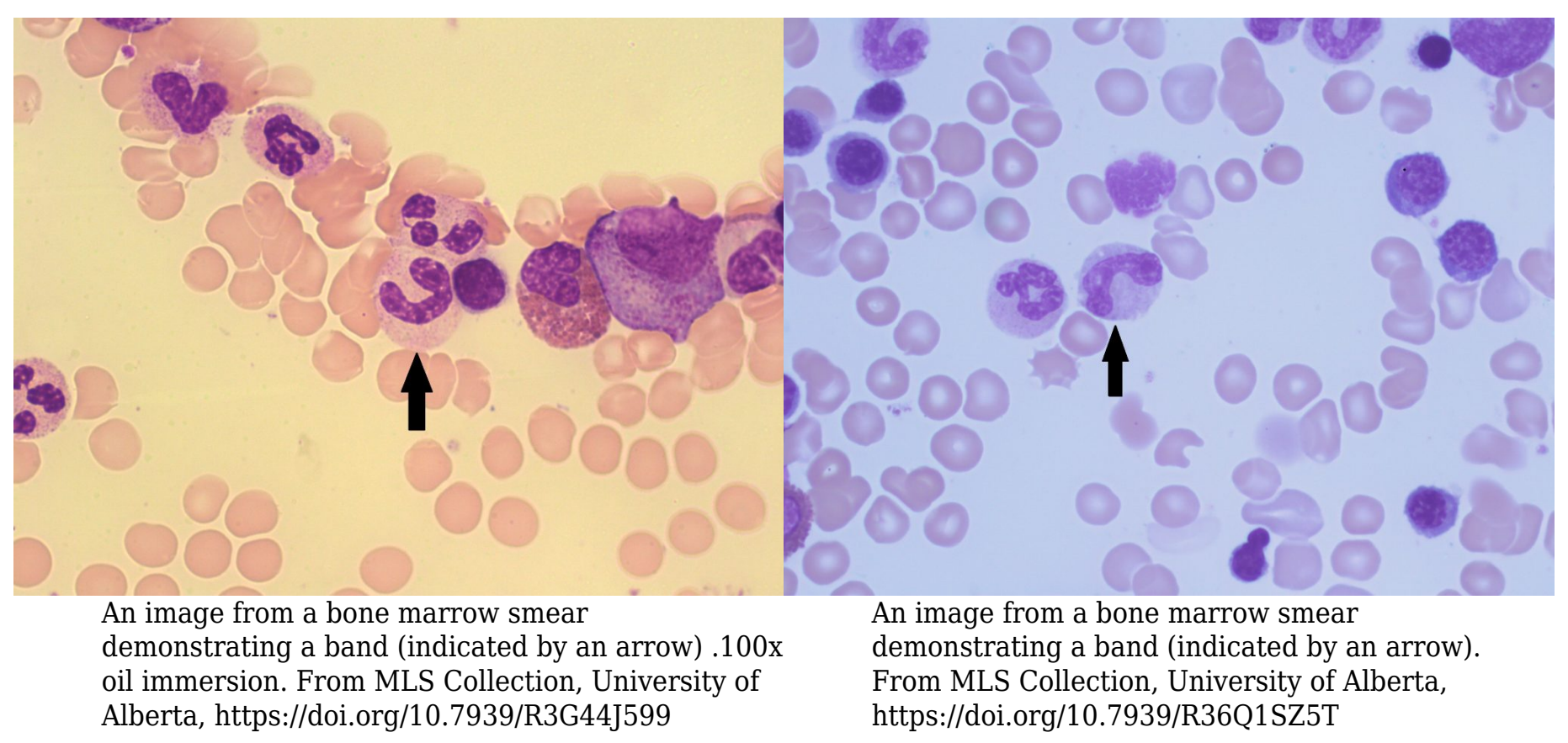

Notes: Stage shows a nucleus with a larger indentation than a metamyelocyte but it still considered non-segmented. ${ }^{1}$

Nucleus-to-Cytoplasm Ratio: Cytoplasm predominates ${ }^{2}$

Nucleoli: Not visible ${ }^{2}$

\section{Nucleus: ${ }^{1,3}$}

Indentation takes up more than one-third of the diameter of the hypothetical round nucleus.

Appears C, U, or S shaped

Centrally or eccentrically located

Dark purple, coarse, clumped chromatin

\section{Cytoplasm: $:^{2-5}$}




\begin{tabular}{ccc}
\hline \multicolumn{2}{l}{ A Laboratory Guide to Clinical Hematology } \\
\hline Granulocyte & Cytoplasm Colour & Secondary (Coarse, Specific) Granule Colour \\
Neutrophil & pink-tan & azurophilic (reddish-purple) \\
Eosinophil & cream coloured to colourless & eosinophilic (Pale to dark orange) \\
Basophil & pale blue & basophilic (dark purple-black) \\
\hline
\end{tabular}

Normal \% in the Bone Marrow and Peripheral Blood: ${ }^{2,4,5}$

\begin{tabular}{cll}
\hline Granulocyte & \% In Bone Marrow & \% In Peripheral Blood \\
Neutrophil & $7-33 \%$ & $0-5 \%$ \\
Eosinophil & $0-2 \%$ & Rare \\
Basophil & $0-1 \%$ & N/A \\
\hline
\end{tabular}

\section{Mature (Segmented) Granulocyte}

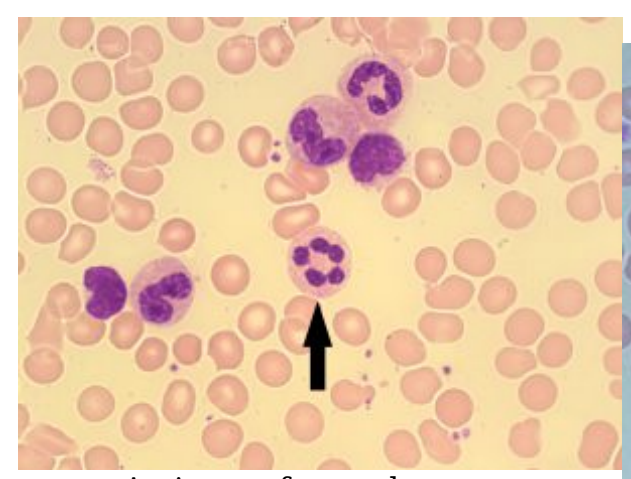

An image from a bone marrow smear showing a mature, segmented neutrophil (indicated by an arrow). 100x oil immersion. From MLS Collection, University of Alberta, https://doi.org/10.7939/R31V5B V7D

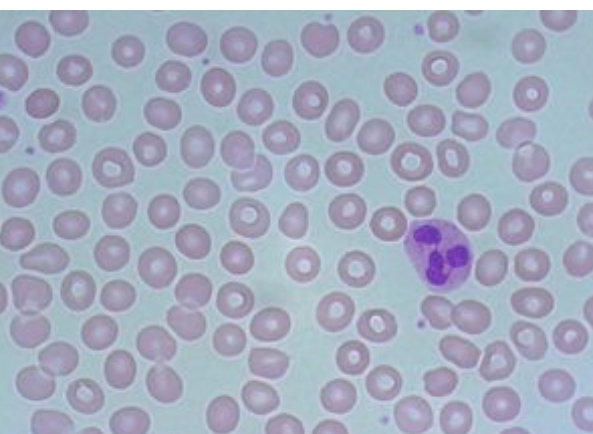

An image from a peripheral blood smear showing a neutrophil. 100x oil immersion. From MLS Collection, University of Alberta, https://doi.org/10.7939/R39Z90 TOG
An image from a peripheral blood smear with a mature eosinophil (top left). 50x oil immersion. From MLS Collection, University of Alberta, https://doi.org/10.7939/R3599Z H07 


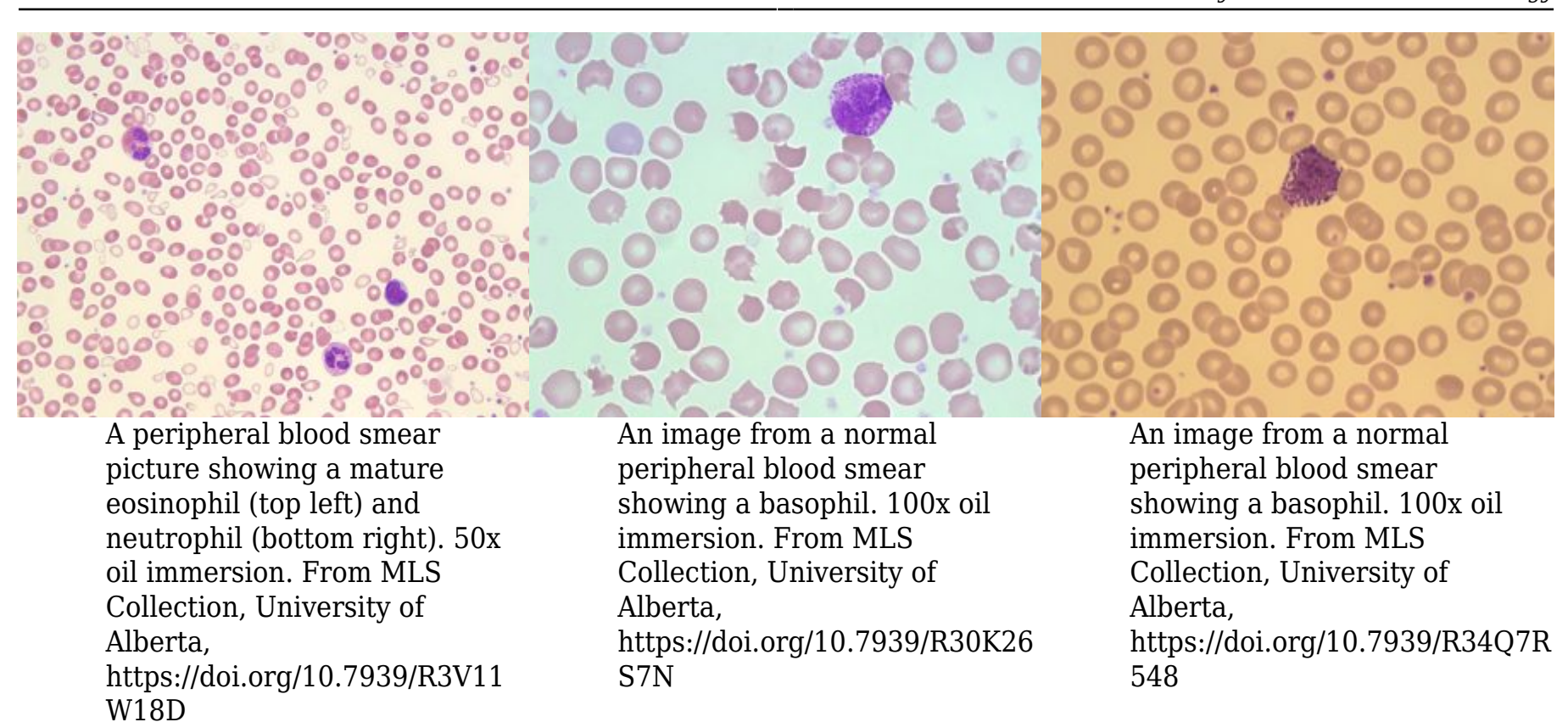

Nucleus-to-Cytoplasm Ratio: Cytoplasm predominates

Nucleoli: Not visible ${ }^{2}$

\section{Nucleus: $:^{1-5}$}

Centrally or eccentrically located

Coarse, clumpy, dark purple staining chromatin

Nucleus is separated into lobes which are all connected by chromatin filaments:

Granulocyte

Neutrophil

Eosinophil

Basophiil
Normal Number of Segmented Lobes

Usually 2, often obscured by granules

\section{Cytoplasm: ${ }^{2,4,5}$}




\begin{tabular}{ccc}
\hline A Laboratory Guide to Clinical Hematology & \\
\hline Granulocyte & Cytoplasm Colour & Secondary (Coarse, Specific) Granule Colour \\
Neutrophil & pink-tan & azurophilic (reddish-purple) \\
Eosinophil & cream coloured to colourless & eosinophilic (Pale to dark orange) \\
Basophil & pale blue & basophilic (dark purple-black), often obscure the \\
& nucleus
\end{tabular}

\section{Normal \% in the Bone Marrow and Peripheral Blood: ${ }^{2,4,5}$}

\begin{tabular}{cll}
\hline Granulocyte & \% In Bone Marrow & \% In Peripheral Blood \\
Neutrophil & $3-11 \%$ & $50-70 \%$ \\
Eosinophil & $0-3 \%$ & $0-5 \%$ \\
Basophil & $<1 \%$ & $0-1 \%$ \\
\hline
\end{tabular}

\section{References:}

1. Landis-Piwowar K. Granulocytes and Monocytes. In: Clinical laboratory hematology. 3rd ed. New Jersey: Pearson; 2015. p. 97-121.

2. Rodak BF, Carr JH. Neutrophil maturation. In: Clinical hematology atlas. 5th ed. St. Louis, Missouri: Elsevier Inc.; 2017. p. 41-54.

3. Bell A, Harmening DM, Hughes VC. Morphology of human blood and marrow cells. In: Clinical hematology and fundamentals of hemostasis. 5th ed. Philadelphia: F.A. Davis Company; 2009. p. 1-41.

4. Rodak BF, Carr JH. Eosinophil maturation. In: Clinical hematology atlas. 5th ed. St. Louis, Missouri: Elsevier Inc.; 2017. p. 65-74.

5. Rodak BF, Carr JH. Basophil maturation. In: Clinical hematology atlas. 5th ed. St. Louis, Missouri: Elsevier Inc.; 2017. p. 75-8. 


\section{Lymphocytes}

\section{MICHELLE TO AND VALENTIN VILLATORO}

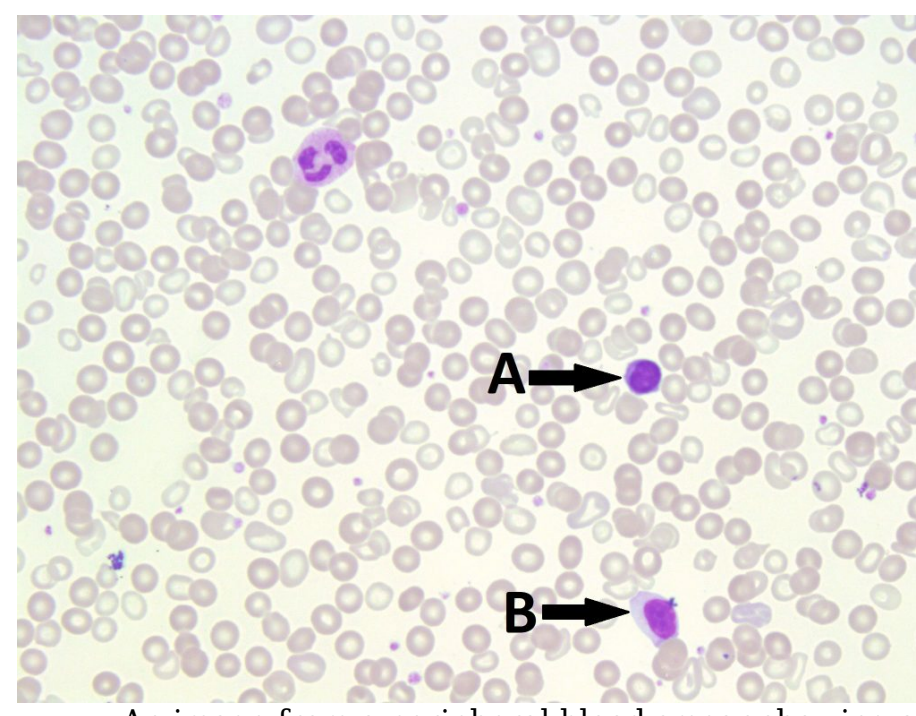

An image from a peripheral blood smear showing a small lymphocyte (A) and a large lymphocyte (B). 50x oil immersion. From MLS Collection, University of Alberta, https://doi.org/10.7939/R3JH3DH6Q

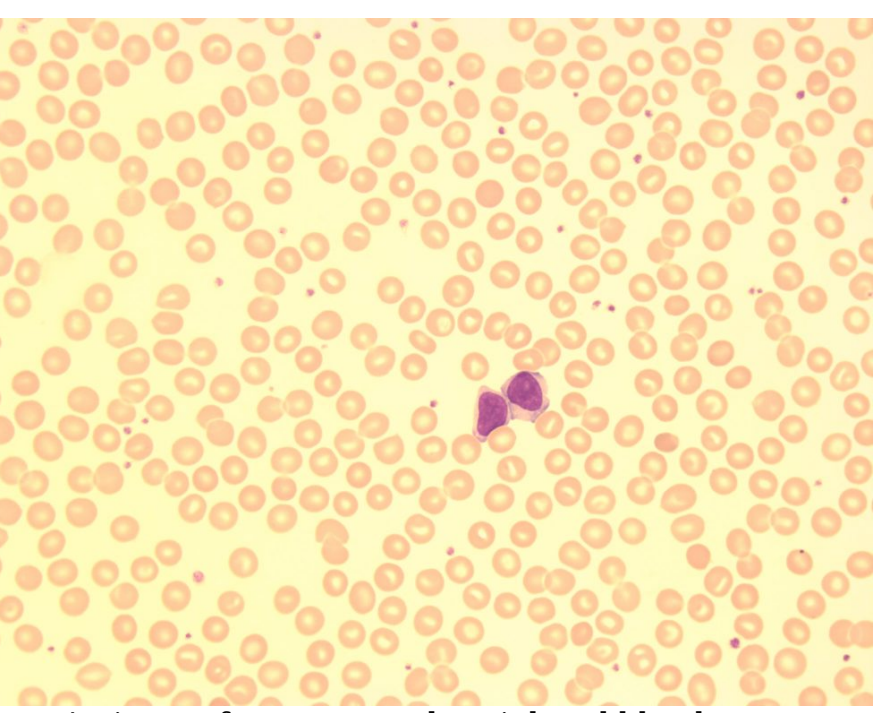

An image from a normal peripheral blood smear showing two large lymphocytes. 100x oil immersion. From MLS Collection, University of Alberta, https://doi.org/10.7939/R30Z71C10

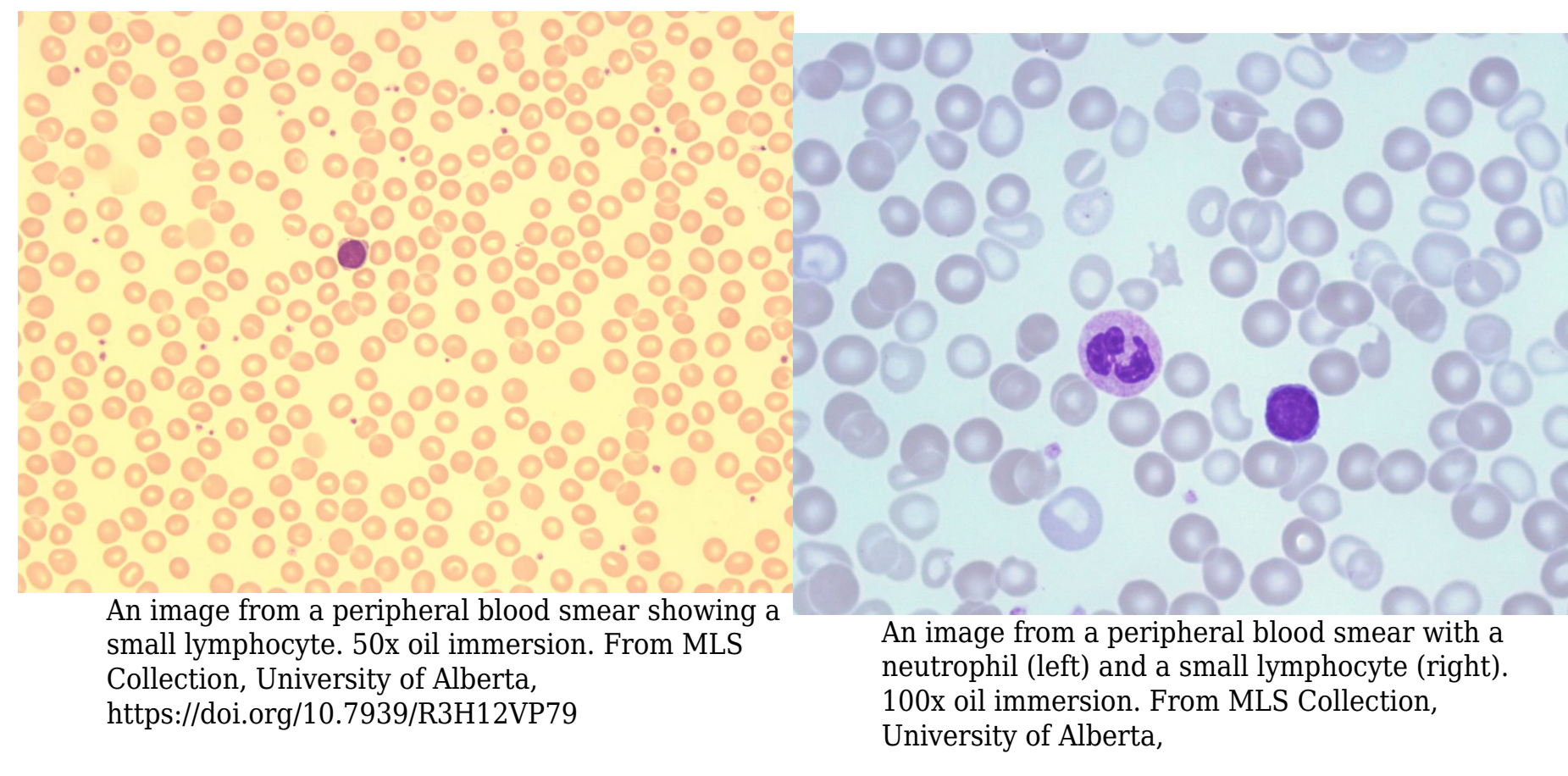


Notes: Can be characterized as being small or large depending on the amount of cytoplasm. Small lymphocytes are more uniform in appearance whereas large lymphocytes have a variable appearance. ${ }^{1}$

Nucleus-to-Cytoplasm Ratio: 5:1 to 2:1 ${ }^{1,2}$

Nucleoli: May be visible ${ }^{1,2}$

Nucleus: ${ }^{1,2}$

Round, oval, or indented

Dark purple, dense chromatin (heterochromatin)

\section{Cytoplasm: ${ }^{1,2}$}

Pale blue

Scant to moderate

Vacuoles may be present

\section{Granules: $:^{1,2}$}

Large: Azurophilic granules may be present

Small: typically lack granules (agranular)

Normal \% in Bone Marrow: 5-15\% ${ }^{2}$ 
Normal \% in Peripheral Blood: $20-40 \%^{2}$

\section{Lymphocyte Lineage}

Lymphocytes can be characterized into two cell types depending on the site of cell maturation:

\section{B Cells}

Lymphocytes that mature in the bone marrow. These cells are lymphocytes that are able to mature into plasma cells and take part in antibody production. ${ }^{1}$

Specific surface markers: ${ }^{1,3}$

CD10, CD19, CD20, D21, CD22, D24, CD38

\section{T Cells}

Lymphocytes that mature in the thymus and lymphoid tissues. When these cells become activated, they are able to take part in cell-mediated immunity. ${ }^{1}$

Specific surface markers: ${ }^{1,3}$

CD2, CD3, CD4, CD5, CD7, CD8, CD25 


\section{References:}

1. Williams L, Finnegan K. Lymphocytes. In: Clinical laboratory hematology. 3rd ed. New Jersey: Pearson; 2015. p. 122-43.

2. Rodak BF, Carr JH. Lymphocyte maturation. In: Clinical hematology atlas. 5th ed. St. Louis, Missouri: Elsevier Inc.; 2017. p. 79-88.

3. Czader M. Flow cytometric analysis in hematologic disorders. In: Rodak's hematology clinical applications and principles. 5th ed. St. Louis, Missouri: Saunders; 2015. p. 543-60. 


\section{7}

\section{Plasma Cells}

\section{MICHELLE TO AND VALENTIN VILLATORO}

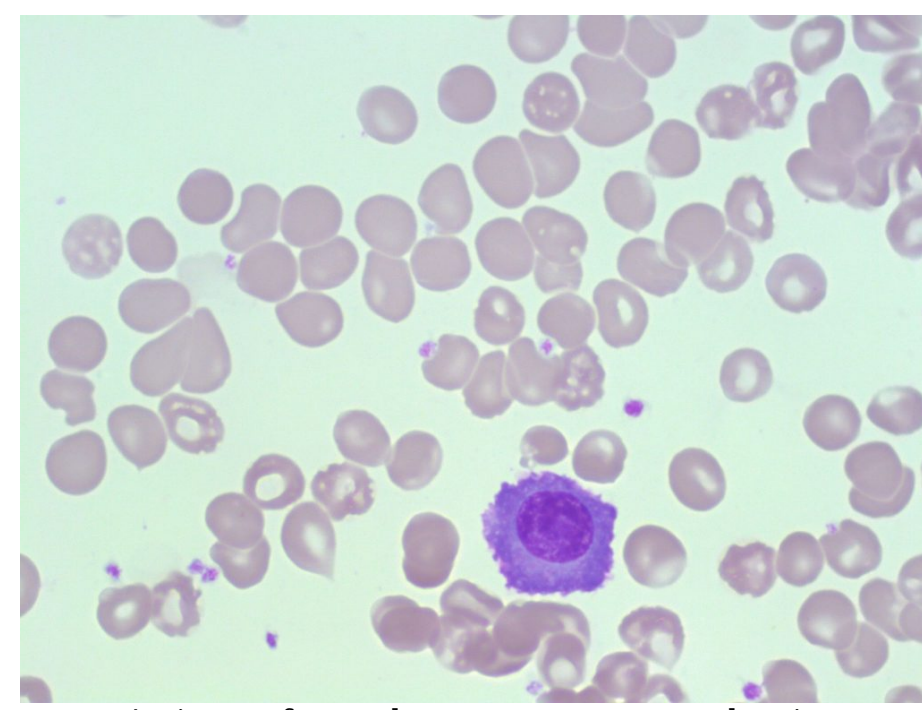

An image from a bone marrow smear showing a plasma cell. Note the perinuclear clearing surrounding the nucleus. 100z oil immersion. From MLS Collection, University of Alberta, https://doi.org/10.7939/R30C4T111

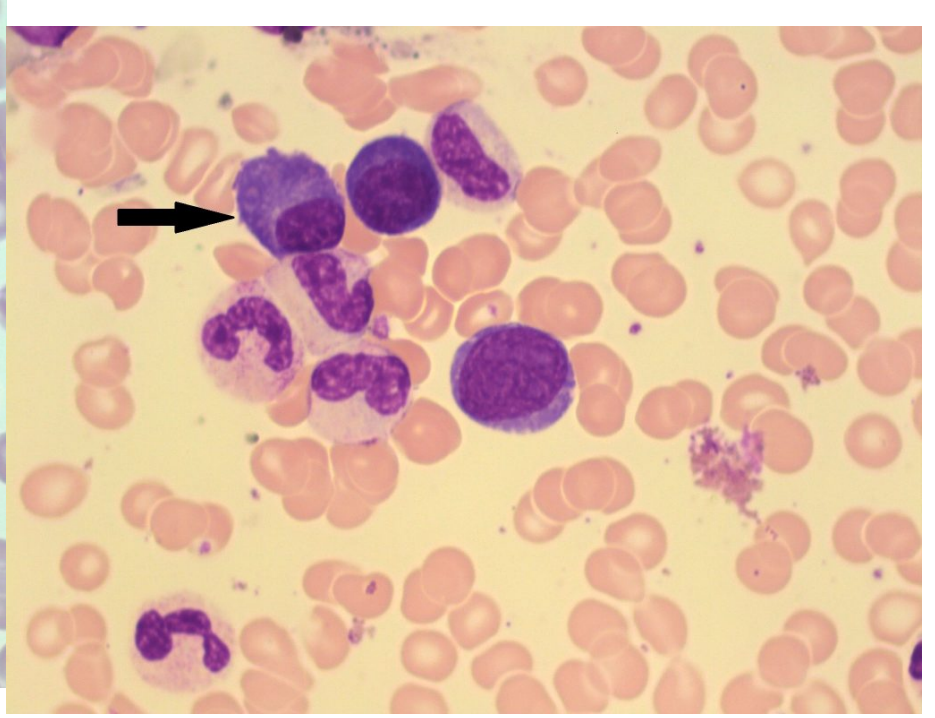

An image from a bone marrow smear with a plasma cell (indicated by an arrow). 100x oil immersion. From MLS Collection, University of Alberta, https://doi.org/10.7939/R3JM23X5J

Notes: The maturation of a lymphocyte to a plasma cell marks the production of immunoglobulins. Lymphocytes that mature into plasma cells are of B lineage. ${ }^{1}$

Nucleus-to-Cytoplasm Ratio: 2:1 to 1:1 ${ }^{2}$

Nucleoli: None ${ }^{1,2}$

\section{Nucleus: ${ }^{1,2}$}


Round or oval

Eccentrically located

Coarse, clumpy, dark purple staining chromatin

\section{Cytoplasm: ${ }^{1,2}$}

Abundant

Darkly basophilic

Perinuclear (clear) zone may be seen around the nucleus (Representing the golgi body)

Vacuoles may be present

Normal \% in Bone Marrow: 0-1\% ${ }^{1,2}$

Normal \% in Peripheral Blood: $0 \%{ }^{1,2}$

\section{References:}

1. Williams L, Finnegan K. Lymphocytes. In: Clinical laboratory hematology. 3rd ed. New Jersey: Pearson; 2015. p. 122-43.

2. Rodak BF, Carr JH. Lymphocyte maturation. In: Clinical hematology atlas. 5th ed. St. Louis, Missouri: Elsevier Inc.; 2017. p. 79-88. 


\section{8}

\section{Monocytes}

\section{MICHELLE TO AND VALENTIN VILLATORO}

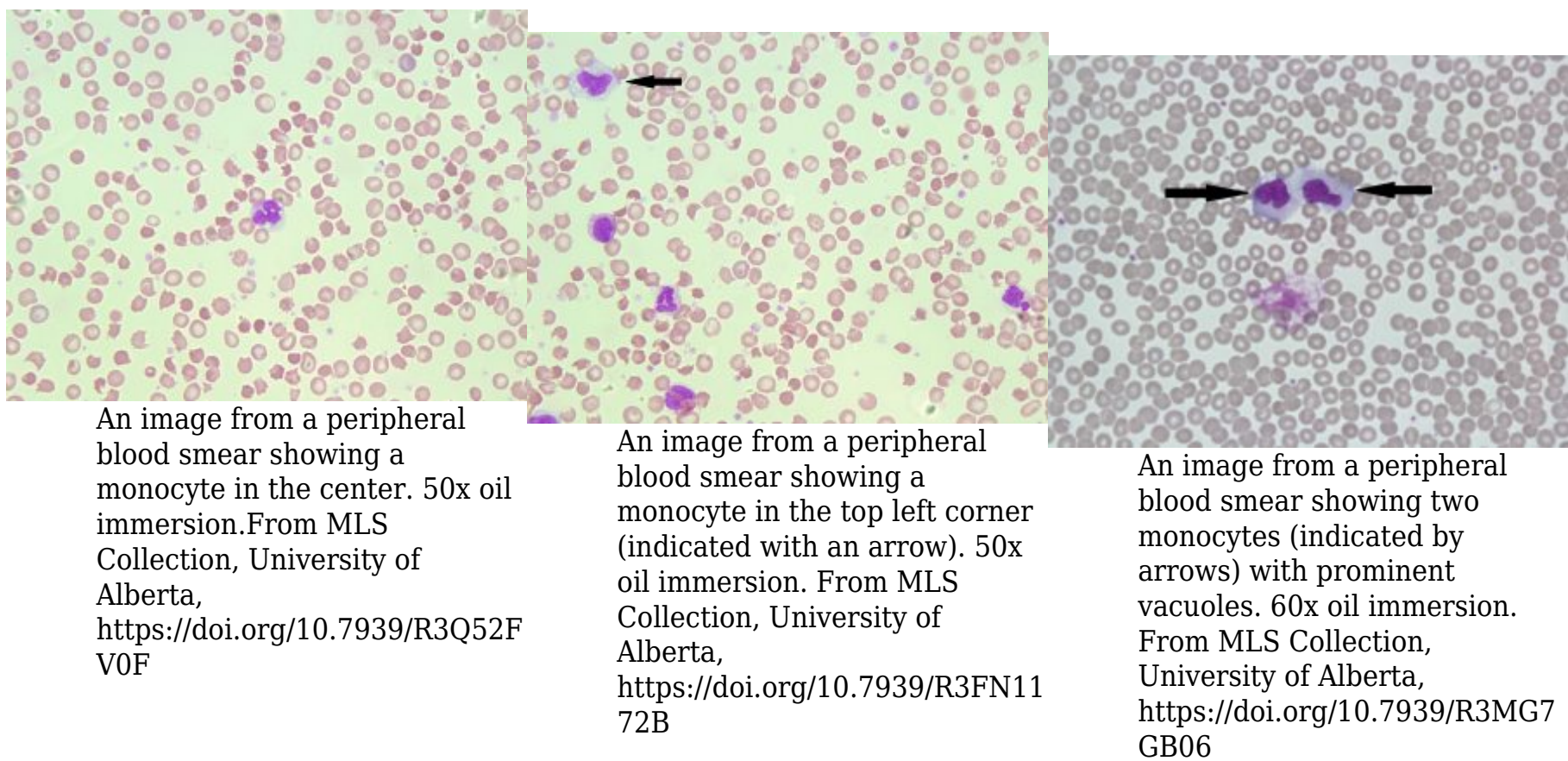

Notes: Monocyte nuclear and cytoplasmic morphology can be highly variable. ${ }^{1}$

Nucleus-to-Cytoplasm Ratio: Variable ${ }^{2}$

Nucleoli: Not visible ${ }^{2}$

\section{Nucleus: ${ }^{1,2}$}

Variable shapes (Folds, kidney shaped) 
Loose, lacy, violet chromatin

\section{Cytoplasm: ${ }^{1,2}$}

Blue-gray cytoplasm (Ground glass appearance due to fine, diffuse granules)

May have pseudopods

May have vacuoles

Normal \% in Bone Marrow: $2 \%^{2}$

Normal \% in Peripheral Blood: 3-11\% ${ }^{2}$

\section{References:}

1. Landis-Piwowar K. Granulocytes and Monocytes. In: Clinical laboratory hematology. 3rd ed. New Jersey: Pearson; 2015. p. 97-121.

2. Rodak BF, Carr JH. Monocyte maturation. In: Clinical hematology atlas. 5th ed. St. Louis, Missouri: Elsevier Inc.; 2017. p. 55-64. 


\section{9}

\section{Macrophages}

\section{MICHELLE TO AND VALENTIN VILLATORO}

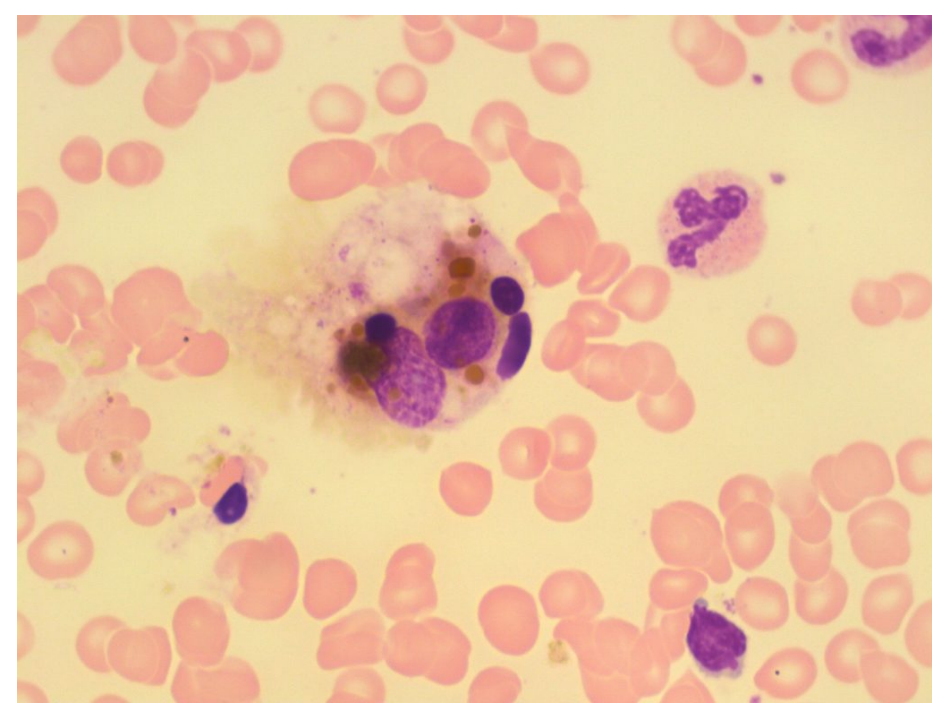

An image from a bone marrow smear showing a macrophage with a valuolated and granular cytoplasm. 100x oil immersion. From MLS Collection, University of Alberta, https://doi.org/10.7939/R3DV1D40B
An image from a Cerebrospinal Fluid (CSF) cytospin slide showing erythrophagocytosis in a macrophage. Ingested red blood cells, vacuolation, and hemosiderin granules can be seen within the cell. 60x oil immersion. From MLS Collection, University of Alberta, https://doi.org/10.7939/R36H4D570

Notes: Macrophages represent the mature form of monocytes when they leave the circulation and enter the tissues. ${ }^{1}$

Nucleus-to-Cytoplasm Ratio: N/A ${ }^{2}$

Nucleoli: $1-2^{2}$ 


\section{Nucleus: ${ }^{2}$}

Variable shapes (kidney, rounded, indented, oval)

Eccentrically located

Dark purple, coarse, clumped chromatin

\section{Cytoplasm: ${ }^{1,2}$}

Abundant

Irregular shaped

Many azurophilic granules

May contain ingested material and/or storage granules (hemosiderin, red blood cells, lipids, microorganisms, debris)

May contain vacuoles

\section{References:}

1. Landis-Piwowar K. Granulocytes and Monocytes. In: Clinical laboratory hematology. 3rd ed. New Jersey: Pearson; 2015. p. 97-121.

2. Rodak BF, Carr JH. Monocyte maturation. In: Clinical hematology atlas. 5th ed. St. Louis, Missouri: Elsevier Inc.; 2017. p. 55-64. 


\section{0}

\section{Megakaryocytes}

\section{MICHELLE TO AND VALENTIN VILLATORO}

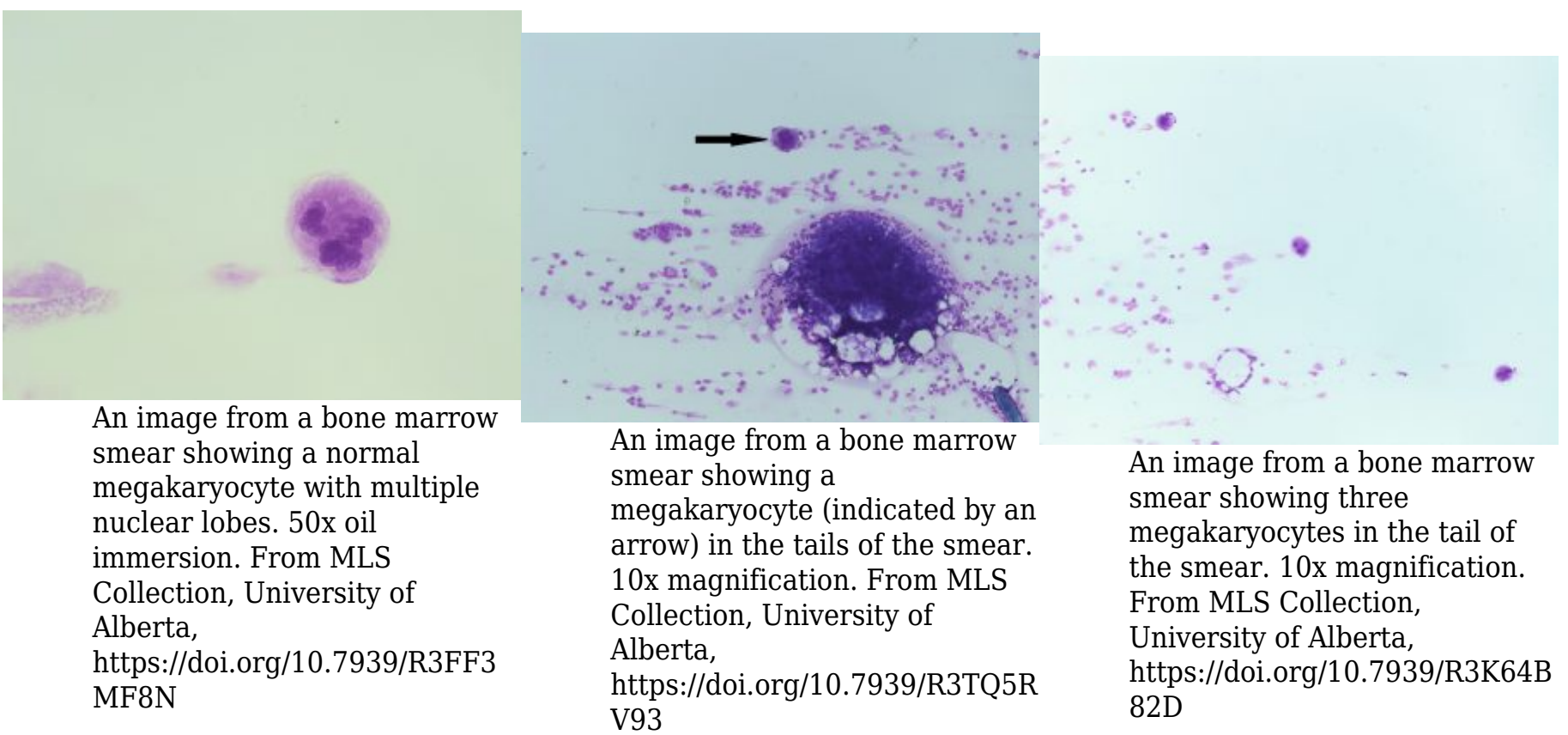

Notes: Develop and are mainly found in the bone marrow. Maturation usually involves the division of nucleus but not the division of the cytoplasm, this gives rise to a polyploid cell. ${ }^{1}$

Nucleus-to-Cytoplasm Ratio: Variable ${ }^{2}$

Nucleoli: N/A ${ }^{2}$

\section{Nucleus:}

Variable number of lobes $(2-32)^{2}$ 


\section{Cytoplasm: ${ }^{2}$}

Abundant

Blue to purple cytoplasm

Reddish blue granules may be visible

\% in Bone Marrow: 5-10 (per field at 100x magnification) ${ }^{2}$

\% in Peripheral Blood: None

\section{References:}

1. Lynne Williams J. The Platelet. In: Clinical laboratory hematology. 3rd ed. New Jersey: Pearson; 2015.

p. 144-53.

2. Rodak BF, Carr JH. Megakaryocyte maturation. In: Clinical hematology atlas. 5th ed. St. Louis, Missouri: Elsevier Inc.; 2017. p. 31-40. 


\section{1}

\section{Platelets}

\section{MICHELLE TO AND VALENTIN VILLATORO}

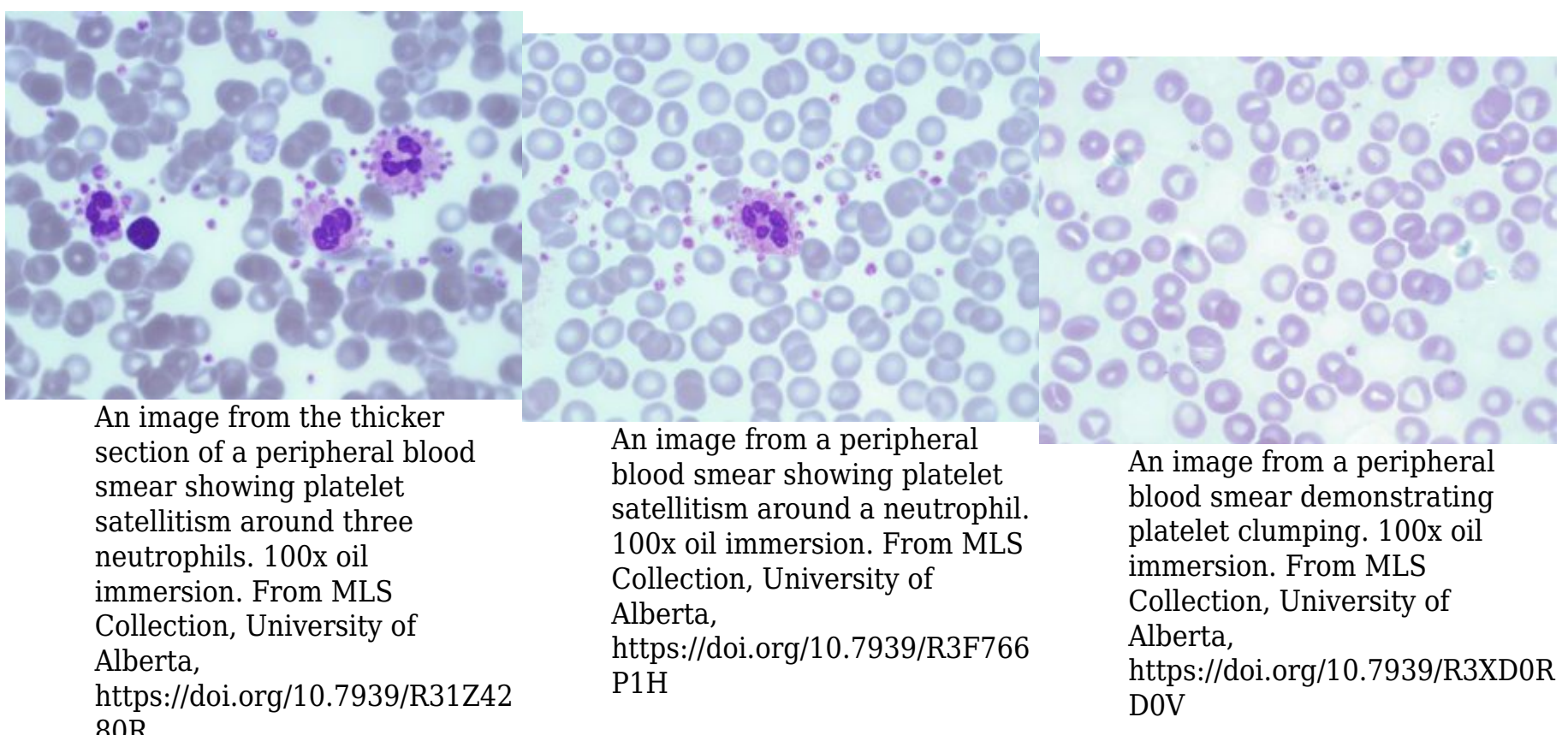

Notes: Platelets are cytoplasmic fragmentations from a megakaryocyte. Fragmentation occurs by the megakaryocyte demarcation membrane system. ${ }^{1}$

Nucleus-to-Cytoplasm Ratio: N/A

Nucleoli: N/A ${ }^{2}$

Nucleus: N/A 


\section{Cytoplasm: ${ }^{1,2}$}

Light blue to colourless

Azurophilic granules present

$\%$ in Bone Marrow: N/A

\% in Peripheral Blood: 7-25 per field (100x oil immersion field)

\section{Reticulated Platelets}

Immature platelets that contain an abundant amount of RNA. ${ }^{1}$

\section{Platelet Clumps and Satellitism}

Platelet satellitism is a phenomenon that can occur in vitro when a blood sample is collected in an EDTA anticoagulant tube. Platelets adhere to neutrophils by an antibody mediated process and this results in falsely decreased platelet counts. ${ }^{3,4}$

Platelet clumping can also occur when blood is collected in an EDTA tube. Platelets become activated and aggregate. EDTA causes some cell antigens to be unmasked and react with antibodies in the serum. ${ }^{3,4}$

In both cases, the issue may be corrected when blood samples are collected in sodium citrate anticoagulated tubes. ${ }^{3,4}$ 


\section{References:}

1. Lynne Williams J. The Platelet. In: Clinical laboratory hematology. 3rd ed. New Jersey: Pearson; 2015. p. 144-53.

2. Rodak BF, Carr JH. Megakaryocyte maturation. In: Clinical hematology atlas. 5th ed. St. Louis, Missouri: Elsevier Inc.; 2017. p. 31-40.

3. Burns C, Dotson M. Hematology Procedures. In: Clinical laboratory hematology. 3rd ed. New Jersey: Pearson; 2015. p. 782-814.

4. Clark KS, Hippe TGl. Manual, semiautomated, and point-of-care testing in hematology. In: Rodak's hematology clinical applications and principles. 5th ed. St. Louis, Missouri: Saunders; 2015. p.187-207. 


\section{XI \\ WHITE BLOOD CELLS: \\ NON-MALIGNANT LEUKOCYTE DISORDERS}




\title{
62
}

\section{Neutrophil Hyposegmentation}

\author{
VALENTIN VILLATORO AND MICHELLE TO
}

\section{Hyposegmentation}

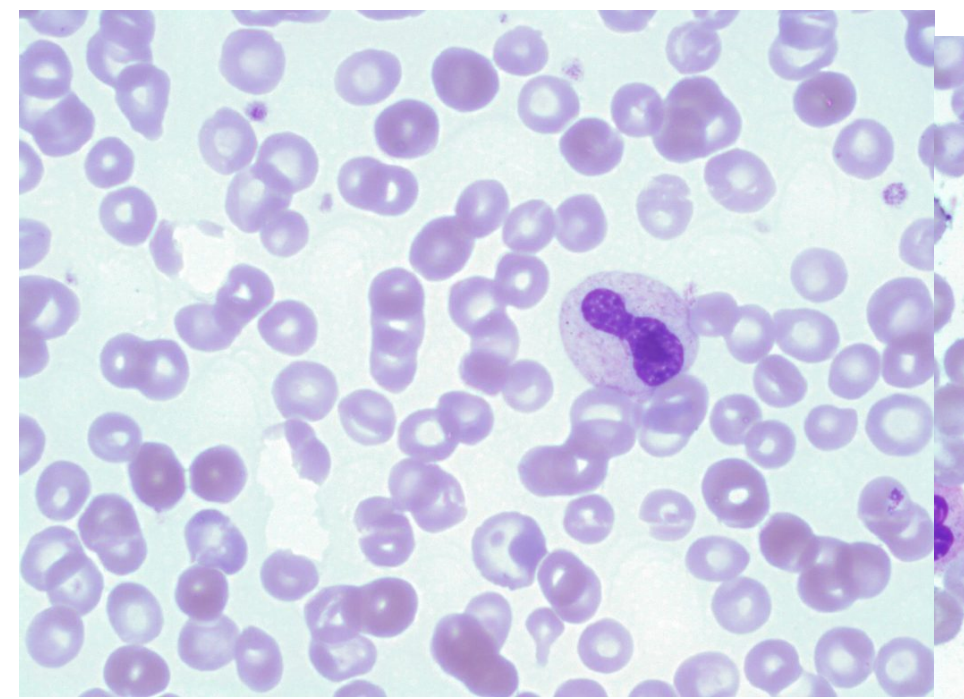

An image from a peripheral blood smear showing a mildly hypogranular and hyposegmented neutorphil. Note the mature cytoplasm colour and nuclear chromatin pattern. 100x oil immersion. From MLS Collection, University of Alberta, https://doi.org/10.7939/R30863M82

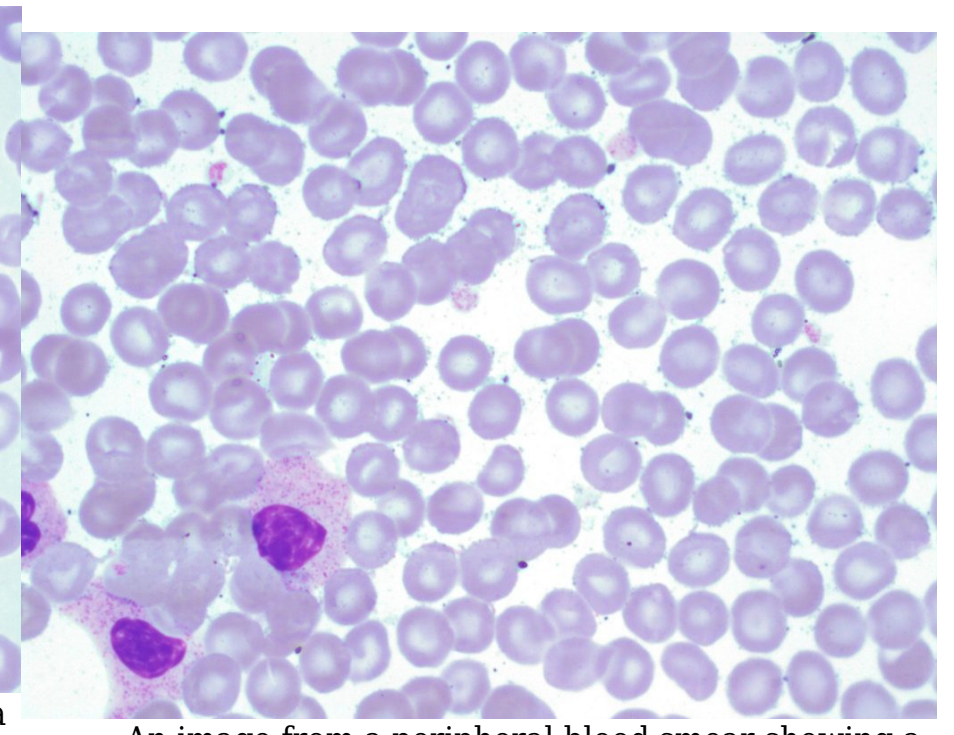

An image from a peripheral blood smear showing a unilobed (hyposegmented) neutrophil. 100x oil immersion. From MLS Collection, University of Alberta, https://doi.org/10.7939/R3JW8733H

If there are many mature granulocytes that have a nucleus with less than 3 lobes, they are considered to be hyposegmented. ${ }^{1}$ The term "Pelger Huet" or "Pseudo Perlget Huet" may also be used depending on the context.

\section{Related Conditions: ${ }^{2}$}

Pelger-Huet Anomaly 
Pseudo-Pelger-Huet Anomaly

\section{References:}

1. Landis-Piwowar K. Granulocytes and Monocytes. In: Clinical laboratory hematology. 3rd ed. New Jersey: Pearson; 2015. p. 97-121.

2. Rodak BF, Carr JH. Nuclear and cytoplasmic changes in leukocytes. In: Clinical hematology atlas. 5th ed. St. Louis, Missouri: Elsevier Inc.; 2017. p. 131-38. 


\section{3}

Neutrophil Hypersegmentation

Neutrophil Hypersegmentation

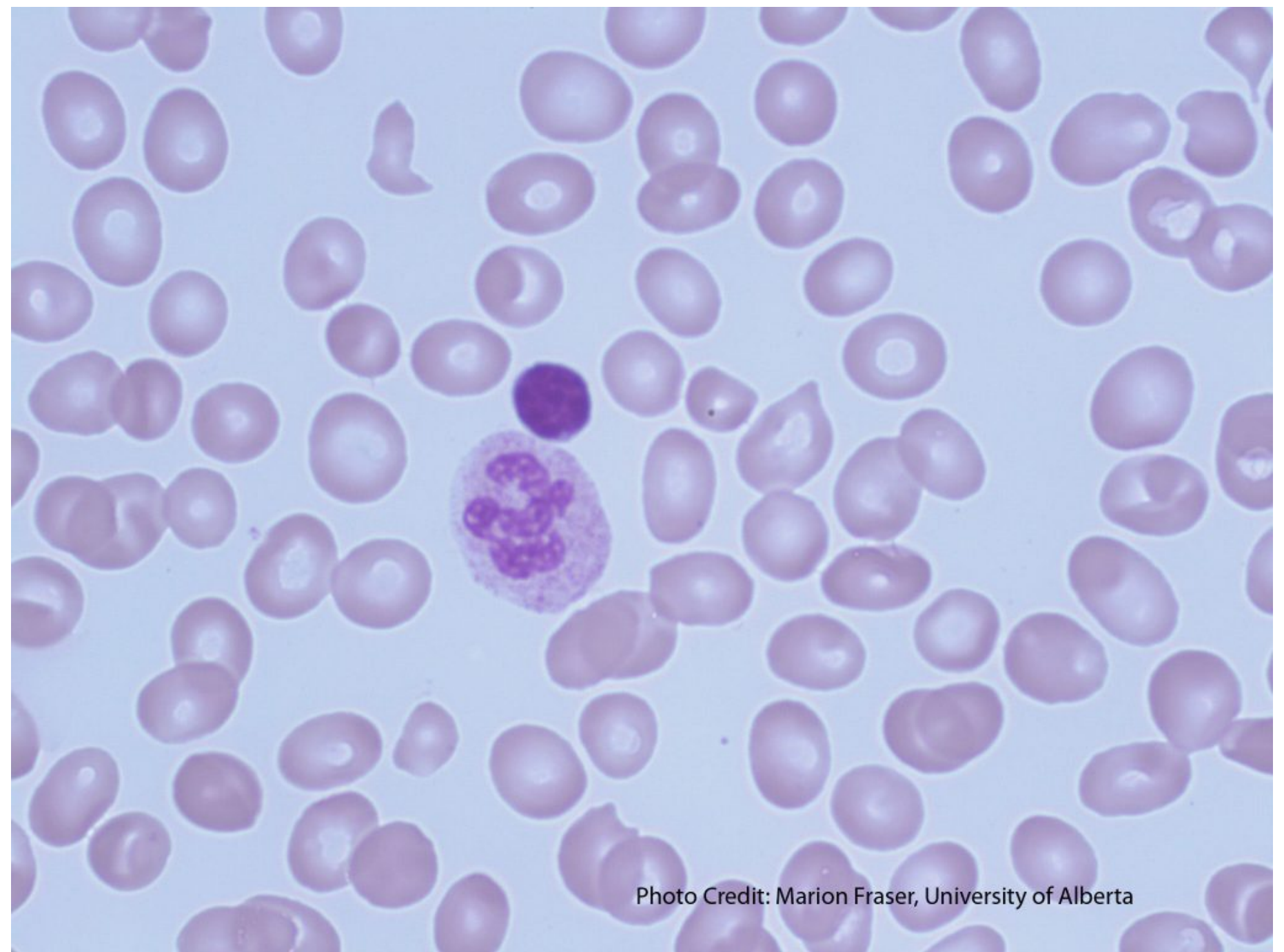

This smear demonstrates a hypersegmented neutrophil. 100x magnification. From MLS Collection, University of Alberta, https://doi.org/10.7939/R3GT5FX0V 
If there are many mature granulocytes that have a nucleus with 5 or more lobes, they are considered to be hypersegmented. ${ }^{1}$

\section{Related Conditions: ${ }^{2}$}

Megaloblastic Anemia

Myelodysplastic Syndromes

Chronic Infections

\section{References:}

1. Landis-Piwowar K. Granulocytes and Monocytes. In: Clinical laboratory hematology. 3rd ed. New Jersey: Pearson; 2015. p. 97-121.

2. Rodak BF, Carr JH. Nuclear and cytoplasmic changes in leukocytes. In: Clinical hematology atlas. 5th ed. St. Louis, Missouri: Elsevier Inc.; 2017. p. 131-38. 


\section{4}

\section{Toxic Changes}

\section{MICHELLE TO AND VALENTIN VILLATORO}

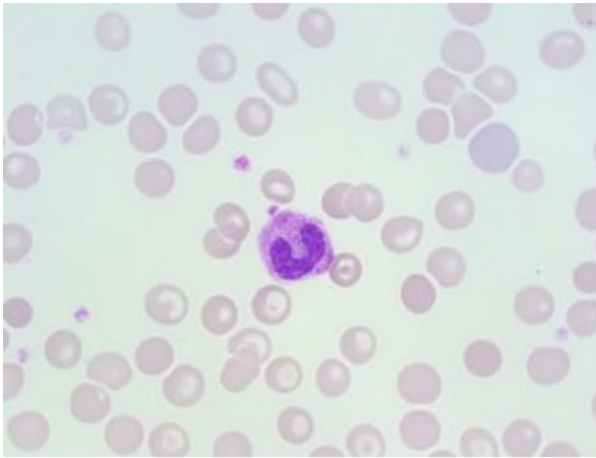

An image from a peripheral blood smear showing a band with a blue dohle body inclusion found in the center of the cell and toxic granulation. 100x oil immersion. From MLS Collection, University of Alberta, https://doi.org/10.7939/R3930P 95D

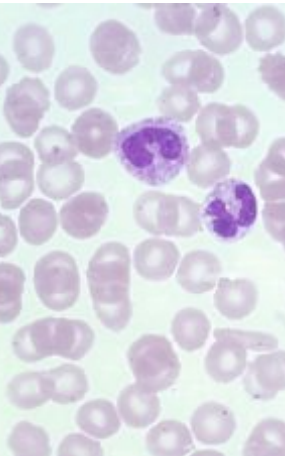

An image from a peripheral blood smear showing toxic changes (Granulation, vacuolation) in two neutrophils. 100x oil immersion. From MLS Collection, University of Alberta, https://doi.org/10.7939/R38912 $61 \mathrm{~T}$

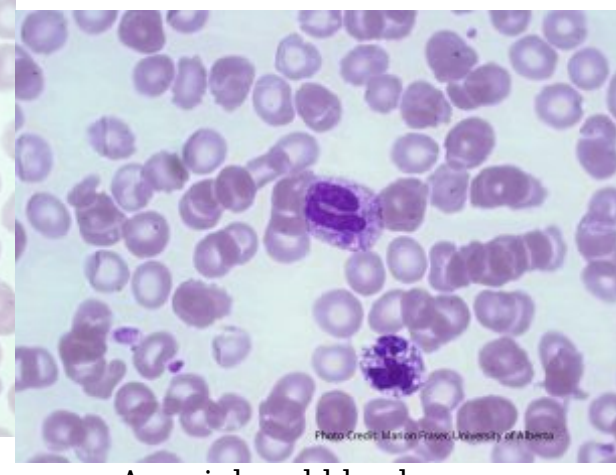

A peripheral blood smear picture showing granulocytes with toxic changes. The Band (center) shows toxic granulation and a dohle body. The neutrophil (bottom) shows toxic vacuolation. From MLS Collection, University of Alberta, https://doi.org/10.7939/R3HT2 GT1K

\section{Cell Features: ${ }^{1,2}$}

Toxic morphological changes are seen in neutrophils. A left shift with an increase in immature granulocytes typically accompanies toxic changes. In order to report toxic changes, typically two out of the three features should be seen in the majority of neutrophils:

\section{Toxic Granulation: ${ }^{1-3}$}

Dark blue-black peroxidase positive granules that appear in the cytoplasm of the neutrophil. Appear very similar to Alder-Reilly bodies found in Alder-Reilly anomaly but is commonly found with other features of toxicity. Can be found in mature neutrophils, bands, and metamyelocytes. 


\section{Toxic Vacuolation: ${ }^{1-3}$}

Clear, circular, and unstained cytoplasmic areas that represent phagocytosis or autophagocytosis. Vacuoles may contain bacteria or yeast if the patient is septic.

\section{Dohle Bodies: ${ }^{1-3}$}

Pale blue, round or elongated cytoplasmic inclusions containing remnant ribosomal ribonucleic acid (RNA) in parallel rows (rough endoplasmic reticulum). Often present in mature neutrophils and bands near the periphery of the cell. Bodies are non-specific and can appear in several conditions such as pregnancy, cancer, burns, and infections.

Note: A left shift is usually seen on the peripheral blood smear when toxicity is present. A Left shift refers to the increase presence of immature bands and myeloid precusors.

\section{Cause: ${ }^{1}$}

Reaction to infection, inflammation, stress, and granulocyte colony-stimulating factor therapy

\section{Laboratory Features: ${ }^{1,2}$}

CBCD:

Moderate leukocytosis Neutrophilia

\section{Peripheral Blood Smear:}

At least 2 of 3 toxic changes in the majority of neutrophils Left shift (often)

\section{References:}

1. Manonneaux S. Nonmalignant leukocyte disorders. In: Rodak's hematology clinical applications and principles. 5th ed. St. Louis, Missouri: Saunders; 2015. p. 475-97. 
2. Jones KW. Evaluation of cell morphology and introduction to platelet and white blood cell morphology. In: Clinical hematology and fundamentals of hemostasis. 5th ed. Philadelphia: F.A. Davis Company; 2009. p. 93-116.

3. Landis-Piwowar K. Nonmalignant disorders of leukocytes: granulocytes and monocytes. In: Clinical laboratory hematology. 3rd ed. New Jersey: Pearson; 2015. p. 388-407. 


\section{5}

Pelger-Huet Anomaly

\section{MICHELLE TO AND VALENTIN VILLATORO}

An interactive or media element has been excluded from this version of the text. You can view it online here: https://pressbooks.library.ualberta.ca/mlsci/?p=643

Images of Pelger-Huet Anomaly in various peripheral blood smears showing numerous hyposegmented neutrophils with mature clumped chromatin. From MLS Collection, University of Alberta.

Image 1: 50x oil immersion. https://doi.org/10.7939/R3DB7W572

Image 2: 50x oil immersion. https://doi.org/10.7939/R32Z13500

Image 3: 50x oil immersion. https://doi.org/10.7939/R3Z60CH59

\section{PBS Key Features: ${ }^{1-4}$}

Neutrophil nuclei appear hyposegmented - can appear as a single round nucleus (unilobed, homozygous Pelger-Huet Anomaly) or dumbbell shaped (bilobed, heterozygous Pelger-Huet Anomaly). Anomaly is differentiated from a left shift by displaying mature chromatin pattern, abundant cytoplasm (low nuclear:cytoplasmic ratio), mature granulation, and an absence of toxic changes.

Congenital Pelger-Huet: granulocytes show normal granulation, 50-90\% of neutrophils are affected.

Pseudo Pelger-Huet: seen in leukocyte malignancies and Myelodysplastic Syndrome, hypogranulation and other Dy's plastic features may be present, 10-30\% of neutrophils are affected. 


\section{Clinical Significance and Cause: ${ }^{1,3,5}$}

Pelger-Huet Anomaly is benign and cell function is normal. Psuedo Pelger-Huet may indicate leukocyte malignancies and myelodysplasia.

Congenital: Lamin $\beta$-receptor gene mutation.

Acquired (Pseudo-Pelger-Huet): Hematologic malignancies such as myelodysplastic syndrome (MDS), acute myeloid leukemia (AML), myeloproliferative neoplasms (MPNs). Pseudo-Pelger-Huet may also be seen during infections, and drug interactions.

\section{Inheritance Pattern: ${ }^{1-3,5}$}

Autosomal dominant

\section{CBC: ${ }^{2}$}

Congenital Pelger-Huet: Cytopenias often absent

Pseudo-Pelger-Huet: Cytopenias often present

\section{References:}

1. Turgeon ML. Nonmalignant Disorders of Granulocytes and monocytes. In: Clinical hematology: theory and procedures. 4th ed. Philadelphia, PA: Lippincott Williams \& Wilkins; 1999. p. 206-16.

2. Cunningham JM, Patnaik MM, Hammerschmidt DE, Vercellotti GM. Historical perspective and clinical implications of the Pelger-Huet cell. Am J Hematol [Internet]. 2009 Oct 20 [cited 2018 Jul 10];84(2):116-9. Available from: https://doi.org/10.1002/ajh.21320

3. Manonneaux S. Nonmalignant leukocyte disorders. In: Rodak's hematology clinical applications and principles. 5th ed. St. Louis, Missouri: Saunders; 2015. p. 475-97. 
4. Harmening DM, Marty J, Strauss RG. Cell biology, disorders of neutrophils, infectious mononucleosis, and reactive lymphocytosis. In: Clinical hematology and fundamentals of hemostasis. 5 th ed. Philadelphia: F.A. Davis Company; 2009. p. 305-30.

5. Landis-Piwowar K. Nonmalignant disorders of leukocytes: granulocytes and monocytes. In: Clinical laboratory hematology. 3rd ed. New Jersey: Pearson; 2015. p. 388-407. 


\section{6}

Chediak-Higashi Syndrome

\section{MICHELLE TO AND VALENTIN VILLATORO}

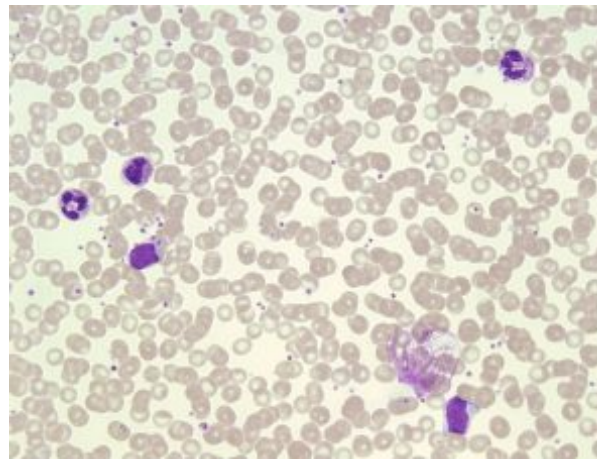

An image of a peripheral blood smear demonstrating neutrophils with abnormally large fused granules seen in Chediak-Higashi Syndrome. 50x oil immersion. From MLS Collection, University of Alberta, https://doi.org/10.7939/R39S1 M158
An image of a peripheral blood smear demonstrating a neutrophil with abnormally large fused granules (top) and a lymphocyte containing a single large granule in the cytoplasm (bottom) seen in Chediak-Higashi syndrome. 50x oil immersion. From MLS Collection, University of Alberta, https://doi.org/10.7939/R3707X 414
An image of a peripheral blood smear demonstrating a lymphocyte containing a single large granule in the cytoplasm seen in Chediak-Higashi syndrome. 100X oil immersion. From MLS Collection, University of Alberta, https://doi.org/10.7939/R33776 97R

\section{PBS Key Features: ${ }^{1,2}$}

Leukocytes contain abnormally large lysosomal granules in the cytoplasm. Granules represent the aggregation of primary granules combined with the fusion of secondary granules.

\section{Cause: ${ }^{3}$}

Mutation in the CHS1/LYST gene which encodes for a vesicle transport protein. 


\section{Inheritance Pattern: $:^{3-5}$}

Autosomal recessive

\section{Clinical Significance: ${ }^{1,3-5}$}

Development of lysosomes are abnormal resulting in the fusion of granules. The syndrome results in impaired chemotaxis, defective degranulation, and defective killing of bacteria. Granulocytes, Platelets, Monocytes, and lymphocytes are dysfunctional.

Patients often present with oculocutaneous albinism, recurrent bacterial infections and bleeding tendencies. Complications develop during early childhood.

\section{CBC: $:^{1,2,5}$}

Anemia

Neutropenia

Thrombocytopenia

\section{References:}

1. Harmening DM, Marty J, Strauss RG. Cell biology, disorders of neutrophils, infectious mononucleosis, and reactive lymphocytosis. In: Clinical hematology and fundamentals of hemostasis. 5th ed. Philadelphia: F.A. Davis Company; 2009. p. 305-30.

2. Bain BJ. Morphology of blood cells. In: Blood cells: a practical guide [Internet]. 5th ed. Chichester, UK: John Wiley \& Sons, Ltd; 2015 [cited 2018 Jul 10]: 67-185. Available from: http://doi.wiley.com/10.1002/9781118817322

3. Manonneaux S. Nonmalignant leukocyte disorders. In: Rodak's hematology clinical applications and principles. 5th ed. St. Louis, Missouri: Saunders; 2015. p. 475-97. 
4. Turgeon ML. Nonmalignant Disorders of Granulocytes and monocytes. In: Clinical hematology: theory and procedures. 4th ed. Philadelphia, PA: Lippincott Williams \& Wilkins; 1999. p. 206-16.

5. Landis-Piwowar K. Nonmalignant disorders of leukocytes: granulocytes and monocytes. In: Clinical laboratory hematology. 3rd ed. New Jersey: Pearson; 2015. p. 388-407. 


\section{7}

\section{Alder-Reilly Anomaly}

\section{MICHELLE TO AND VALENTIN VILLATORO}

\section{PBS Key Features: ${ }^{1,2}$}

Granulocytes show metachromatic and darkly staining inclusions (Alder-Reilly bodies) containing partially digested mucopolysaccharides that resemble toxic granulation but are permanent (nontransient). Anomaly is differentiated from toxicity by a lack of Dohle bodies, left shift, and neutrophilia. Abnormal granules may also be seen in lymphocytes and monocytes.

\section{Cause: ${ }^{1,2}$}

Incomplete degradation of mucopolysaccharides (Mucoplysaccharidosis disorder)

\section{Inheritance Pattern: ${ }^{1-3}$}

Autosomal recessive

\section{Clinical Significance: ${ }^{1-5}$}

Leukocyte function is not impaired. Associated syndromes include Tay-Sachs disease, Hunter syndrome, Hurler syndrome, and Maroteaux-Lamy polydystrophic dwarfism which all result in different clinical symptoms.

\section{CBC:}

N/A 


\section{References:}

1. Manonneaux S. Nonmalignant leukocyte disorders. In: Rodak's hematology clinical applications and principles. 5th ed. St. Louis, Missouri: Saunders; 2015. p. 475-97.

2. Harmening DM, Marty J, Strauss RG. Cell biology, disorders of neutrophils, infectious mononucleosis, and reactive lymphocytosis. In: Clinical hematology and fundamentals of hemostasis. 5th ed. Philadelphia: F.A. Davis Company; 2009. p. 305-30.

3. Turgeon ML. Nonmalignant Disorders of Granulocytes and monocytes. In: Clinical hematology: theory and procedures. 4th ed. Philadelphia, PA: Lippincott Williams \& Wilkins; 1999. p. 206-16.

4. Bain BJ. Morphology of blood cells. In: Blood cells: a practical guide [Internet]. 5th ed. Chichester, UK: John Wiley \& Sons, Ltd; 2015 [cited 2018 Jul 10]: 67-185. Available from: http://doi.wiley.com/10.1002/9781118817322

5. Landis-Piwowar K. Nonmalignant disorders of leukocytes: granulocytes and monocytes. In: Clinical laboratory hematology. 3rd ed. New Jersey: Pearson; 2015. p. 388-407. 


\section{8}

May-Hegglin Anomaly

\section{MICHELLE TO AND VALENTIN VILLATORO}

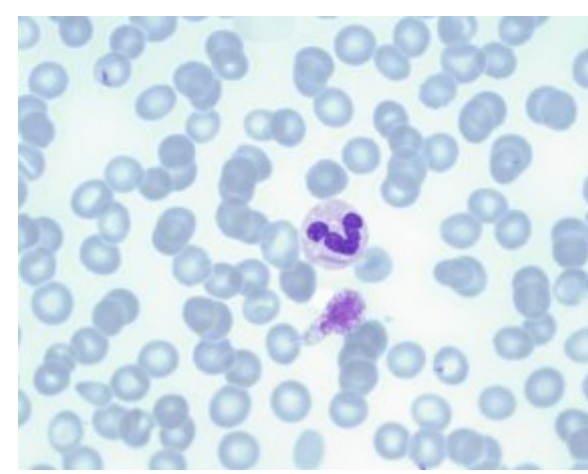

An image from a peripheral blood smear demonstrating a blue dohle body-like inclusion in a neutrophil and a giant platelet seen in May-Hegglin anomaly. 100x oil immersion. From MLS Collection, University of Alberta, https://doi.org/10.7939/R3W669 Q4B

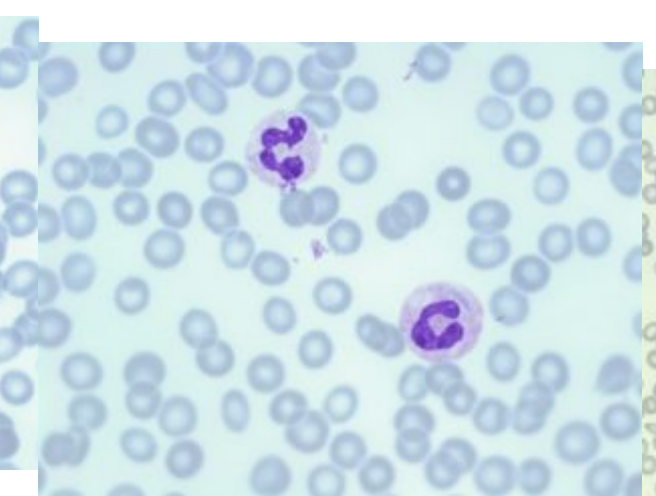

An image from a peripheral blood smear demonstrating blue dohle body-like inclusions in two neutrophils seen in May-Hegglin anomaly. 100x oil immersion. From MLS Collection, University of Alberta, https://doi.org/10.7939/R34Q7R $53 \mathrm{~S}$

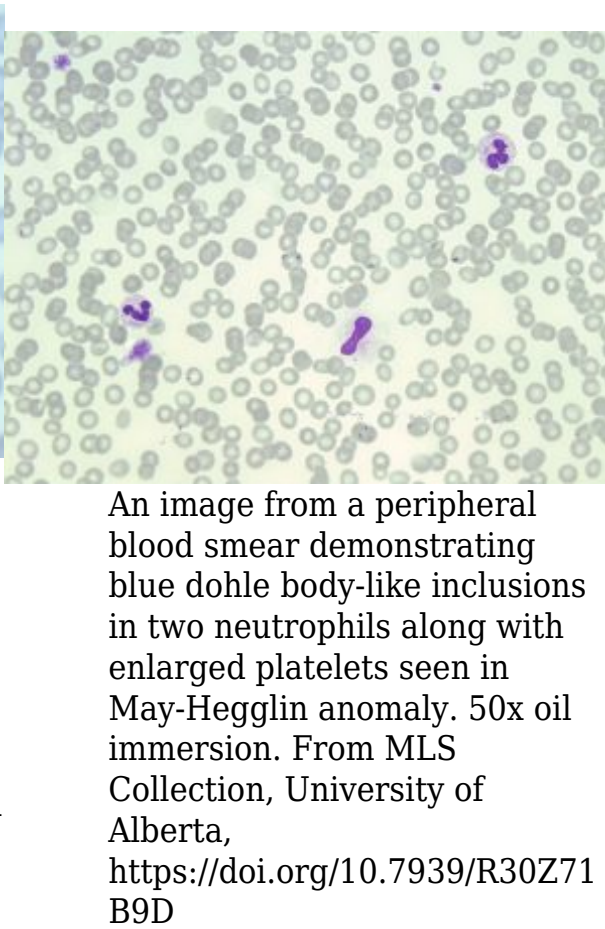

B9D

\section{PBS Key Features: ${ }^{1-4}$}

Graunulocyte and Monoyte cytoplasms contain large basophilic inclusions that resemble Dohle bodies but are much larger and elongated. Inclusions are composed of precipitated myosin heavy chains.

Giant platelets and thrombocytopenia are also associated with this anomaly.

\section{Cause: ${ }^{1}$}




\section{Inheritance Pattern: ${ }^{1,5}$}

Autosomal dominant

\section{Clinical Significance: ${ }^{1-3,5}$}

May-Hegglin anomaly is a platelet disorder that can cause mild bleeding tendencies but majority of patients are asymptomatic. Degree of bleeding is correlated to the degree of thrombocytopenia. Leukocyte function is unaffected.

CBC: ${ }^{1,5}$

Variable thrombocytopenia

\section{References:}

1. Manonneaux S. Nonmalignant leukocyte disorders. In: Rodak's hematology clinical applications and principles. 5th ed. St. Louis, Missouri: Saunders; 2015. p. 475-97.

2. Harmening DM, Marty J, Strauss RG. Cell biology, disorders of neutrophils, infectious mononucleosis, and reactive lymphocytosis. In: Clinical hematology and fundamentals of hemostasis. 5 th ed. Philadelphia: F.A. Davis Company; 2009. p. 305-30.

3. Turgeon ML. Nonmalignant Disorders of Granulocytes and monocytes. In: Clinical hematology: theory and procedures. 4th ed. Philadelphia, PA: Lippincott Williams \& Wilkins; 1999. p. 206-16.

4. Bain BJ. Morphology of blood cells. In: Blood cells: a practical guide [Internet]. 5th ed. Chichester, UK: John Wiley \& Sons, Ltd; 2015 [cited 2018 Jul 10]: 67-185. Available from: http://doi.wiley.com/10.1002/9781118817322

5. Landis-Piwowar K. Nonmalignant disorders of leukocytes: granulocytes and monocytes. In: Clinical laboratory hematology. 3rd ed. New Jersey: Pearson; 2015. p. 388-407. 
69

Chronic Granulomatous Disease

MICHELLE TO AND VALENTIN VILLATORO

PBS: ${ }^{1}$

Leukoctye morphology is normal.

\section{Cause: ${ }^{2}$}

Mutations in the NADPH oxidase subunit genes.

Inheritance Pattern: ${ }^{2-4}$

Autosomal recessive, $\mathrm{X}$-linked recessive

\section{Clinical Significance: $:^{2-4}$}

Antmicrobial activity defect where neutrophils and monocytes are unable to kill catalase positive organisms after ingestion. The respiratory burst is not activated and cells are unable to produce reactive oxygen species and superoxide. Disease results in recurrent and life-threatening bacterial and fungal infections in the first year of life.

Infections occur often in the lung, skin, lymph nodes, and liver. Granuloma formation can be found in various organs and cause obstruction.

\section{Additional Tests: ${ }^{1}$}

Nitroblue Tetrazolium Test (NBT) 
Flow Cytometry

\section{References:}

1. Manonneaux S. Nonmalignant leukocyte disorders. In: Rodak's hematology clinical applications and principles. 5th ed. St. Louis, Missouri: Saunders; 2015. p. 475-97.

2. Harmening DM, Marty J, Strauss RG. Cell biology, disorders of neutrophils, infectious mononucleosis, and reactive lymphocytosis. In: Clinical hematology and fundamentals of hemostasis. 5th ed. Philadelphia: F.A. Davis Company; 2009. p. 305-30.

3. Turgeon ML. Nonmalignant Disorders of Granulocytes and monocytes. In: Clinical hematology: theory and procedures. 4th ed. Philadelphia, PA: Lippincott Williams \& Wilkins; 1999. p. 206-16.

4. Landis-Piwowar K. Nonmalignant disorders of leukocytes: granulocytes and monocytes. In: Clinical laboratory hematology. 3rd ed. New Jersey: Pearson; 2015. p. 388-407. 


\title{
70
}

\section{Infectious Mononucleosis/Reactive Lymphocytes}

\author{
MICHELLE TO AND VALENTIN VILLATORO
}

An interactive or media element has been excluded from this version of the text. You can view it online here: https://pressbooks.library.ualberta.ca/mlsci/?p=667

Images of peripheral blood smears with heterogeneous reactive lymphocytes with prominent basophilic skirting of the cytoplasm. From MLS Collection, University of Alberta.

Image 1: 50x oil immersion. https://doi.org/10.7939/R3G44J57B

Image 2: 50x oil immersion. https://doi.org/10.7939/R34M91R9B

Image 3: 60 x oil immersion. https://doi.org/10.7939/R3GQ6RH6F

\section{Cell Features: ${ }^{1-3}$}

Large reactive (atypical) lymphocytes that represent activated T cells. The cytoplasm shows characteristic basophilic skirting in areas where there is contact with red blood cells. Red blood cells look as if they are creating indents in the cytoplasm. The population of reactive lymphocytes is heterogeneous with diverse shapes and sizes in cytoplasm and nuclear shapes.

\section{Cause: ${ }^{1,3-5}$}

Epstein-Barr Virus (EBV) infection that is usually acute, benign, and self-limiting. 
Young adults (approx. 15-25 years of age)

Common Clinical Symptoms: ${ }^{1,4}$

Classic Triad: Pharyngitis, fever, lymphadenopathy.

\section{Laboratory Features: ${ }^{1,3,5}$}

\section{CBC:}

Leukocytosis

Absolute lymphocytosis
PBS

Reactive lymphocytes

\section{Other Tests: ${ }^{1,3,5}$}

Positive heterophile antibody*

Positive EBV specific antigen and antibody (ELISA)*

Elevated C-reactive protein (CRP)

Viral cultures

Flow cytometry (to rule out malignancies with similar cell morphologies)

*Positivity for antigen or antibody varies depending on the date of testing. Some antigen or antibodies may appear only after a few weeks of infection.

Immunologic Markers: ${ }^{2}$

$\mathrm{CD} 3, \mathrm{CD} 4$ or $\mathrm{CD} 8$ 


\section{References:}

1. Manonneaux S. Nonmalignant leukocyte disorders. In: Rodak's hematology clinical applications and principles. 5th ed. St. Louis, Missouri: Saunders; 2015. p. 475-97.

2. Holmer LD, Bueso-Ramos CE. Chronic lymphocytic leukemia and related lymphoproliferative disorders. In: Clinical hematology and fundamentals of hemostasis. 5th ed. Philadelphia: F.A. Davis Company; 2009. p. 440-65.

3. Beglinger SS. Nonmalignant lymphocyte disorders. In: Clinical laboratory hematology. 3rd ed. New Jersey: Pearson; 2015. p. 409-24.

4. Turgeon ML. Leukocytes: nonmalignant lymphocytic disorders. In: Clinical hematology: theory and procedures. 4th ed. Philadelphia, PA: Lippincott Williams \& Wilkins; 1999. p. 229-43.

5. Harmening DM, Marty J, Strauss RG. Cell biology, disorders of neutrophils, infectious mononucleosis, and reactive lymphocytosis. In: Clinical hematology and fundamentals of hemostasis. 5th ed. Philadelphia: F.A. Davis Company; 2009. p. 305-30. 


\section{XII \\ WHITE BLOOD CELLS: ACUTE LEUKEMIA}




\section{1 \\ Introduction to Leukemias}

\section{MICHELLE TO AND VALENTIN VILLATORO}

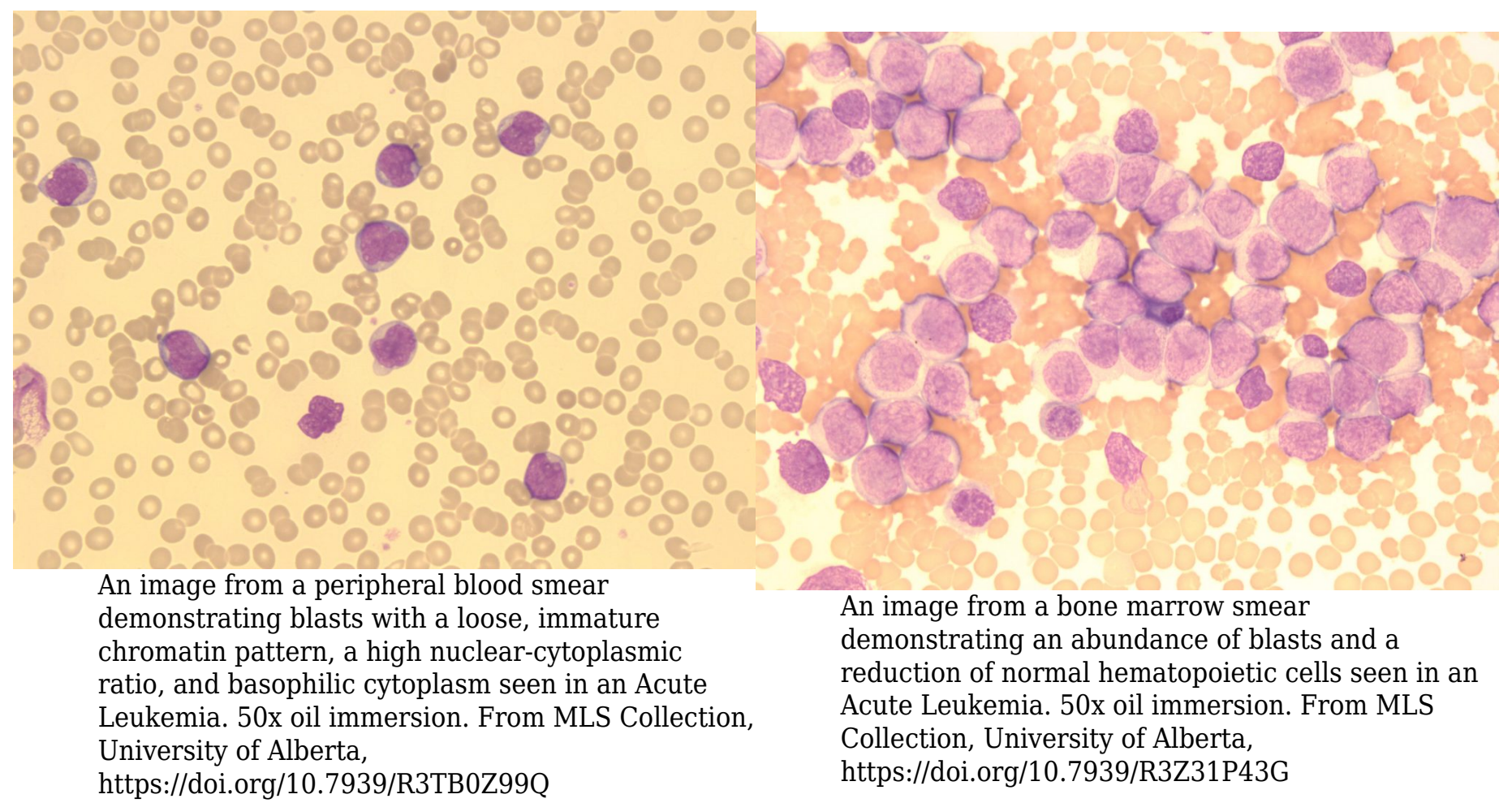

Leukemia: Describes tumors that originate from the bone marrow. ${ }^{1}$

Lymphoma: Describes tumors that originate from the lymphatic tissues. ${ }^{1}$

The causes of acute leukemia are vast. There are a number of factors that can lead to the development of leukemia, such as: genetic mutations, environmental factors (e.g. exposure to drugs, chemicals, radiation), inherited syndromes (e.g. Down syndrome, fanconi anemia), viral infections (e.g. HIV), immunologic dysfunction (e.g. immunosuppressants), or idiopathic factors. ${ }^{1}$ 
There are different classification systems that exist to categorize acute and chronic leukemias. Two examples are the French-American-British (FAB) system and the World Health Organization (WHO) system. $^{1.4}$

Note: Please be aware that these schemes are updated periodically and the sources used in this ebook may not reflect the most current classification systems used.

Leukemias are described as being "acute" or "chronic" and specified as to which cell lineage and maturation stage is affected. ${ }^{5}$

Table 1. Comparison of Acute and Chronic Leukemias. ${ }^{5,6}$

\begin{tabular}{ll}
\hline Acute & Chronic \\
All ages affected & Mainly adults affected \\
Rapid onset & Insidious onset \\
Involve immature cells & Involve mature cells \\
$\geq 20 \% *$ blasts in PBS or BM & $\leq 20 \%$ blasts in PBS or BM \\
& \\
*WHO Classification Criteria & \\
\hline
\end{tabular}

\section{References:}

1. McKenzie SB. Introduction to hematopoietic neoplasms. In: Clinical laboratory hematology. 3rd ed. New Jersey: Pearson; 2015. p. 424-45.

2. Roquiz W, Gandhi P, Kini AR. Acute leukemias. In: Rodak's hematology clinical applications and principles. 5th ed. St. Louis, Missouri: Saunders; 2015. p. 543-60.

3. Swerdlow SH, Campo E, Harris NL, Jaffe ES, Pileri SA, Stein H, et al. editors. WHO Classification of Tumours of Haematopoietic and Lymphoid Tissues Volume 2. 4th ed. International Agency for Research on Cancer (IARC); 2008. 
4. Arber D, Orazi A, Hasserjian R, Thiele J, Borowitz MJ, Le Beau MM, et al. The 2016 revision to the World Health Organization classification of myeloid neoplasms and acute leukemia. Blood [Internet]. 2016 May 19;127(20):2391-405. Available from: http://www.ncbi.nlm.nih.gov/pubmed/27069254

5. Gatter K, Cruz F, Braziel R. Introduction to leukemia and the acute leukemias. In: Clinical hematology and fundamentals of hemostasis. 5th ed. Philadelphia: F.A. Davis Company; 2009. p. 331-370.

6. Bentley G, Leclair SJ. Acute Myeloid Leukemias. In: Clinical laboratory hematology. 3rd ed. New Jersey: Pearson; 2015. p. 500-21. 


\section{2 \\ Acute Lymphoblastic Leukemia (ALL)}

MICHELLE TO AND VALENTIN VILLATORO

WHO Classification (2008): ${ }^{1}$

As of 2008, the WHO has classified ALL into categories based on the the lymphoblast origin and genetic abnormalities:

1. B Lymphoblastic Leukemia/Lymphoma

- With recurrent genetic abnormalities

- Not otherwise specified (NOS)

2. T Lymphoblastic Leukemia/Lymphoma

Affected Age: Primarily children 2-5 years old. ${ }^{2}$

\section{Affected Cell: ${ }^{1}$}

B and T lymphoblasts

\section{ALL Blasts Cell Features: ${ }^{1,3,4}$}

Size: Blasts are variable in size, usually smaller than myeloblasts

Nucleoli: Often indistinct, $0-2$ 
Chromatin: Fine to coarse, dispersed chromatin

Cytoplasm: Usually scant and basophilic, vacuoles may also be present

Auer Rods: Not present

Auer Rods are thought to be fused primary granules and are only found in myeloblasts. Presence of auer rods is distinctive of AML and can be used to differentiate the condition from ALL if they are present. ${ }^{2}$

\section{Laboratory Results for ALL: ${ }^{1,3,5}$}

\begin{tabular}{lll}
\hline CBC: & PBS: & BM: \\
RBC: Decreased & Lymphoblasts & $\geq 20 \%$ Lymphoblasts \\
WBC: Variable & Normocytic & Hypercellular with replacement of normal \\
PLT: Decreased & Normochromic & hematopoietic tissue \\
& Anisocytosis, poikilocytosis, and nRBCs are & \\
& usually not present. & Other Tests: \\
Immunologic Markers: & LD: Increased & Hyperuricemia \\
B cell: TdT, CD10, CD19, CD22, CD24, CD34 & Hypercalcemia & Cytogenetics \\
T cell: TdT, CD1, CD2, CD3, CD4, CD5, CD7, CD8, CD10 & Cytochemical Stains & \\
& & \\
&
\end{tabular}

\section{References:}

1. Swerdlow SH, Campo E, Harris NL, Jaffe ES, Pileri SA, Stein H, et al. editors. WHO Classification of Tumours of Haematopoietic and Lymphoid Tissues Volume 2. 4th ed. International Agency for Research on Cancer (IARC); 2008.

2. McKenzie SB. Introduction to hematopoietic neoplasms. In: Clinical laboratory hematology. 3rd ed. New Jersey: Pearson; 2015. p. 424-45.

3. Leclair SJ, Bentley G.Precursor Lymphoid Neoplasms. 3rd ed. New Jersey: Pearson; 2015. p. 522-34.

4. Gatter K, Cruz F, Braziel R. Introduction to leukemia and the acute leukemias. In: Clinical hematology and fundamentals of hemostasis. 5th ed. Philadelphia: F.A. Davis Company; 2009. p. 
$331-370$.

5. Roquiz W, Gandhi P, Kini AR. Acute leukemias. In: Rodak's hematology clinical applications and principles. 5th ed. St. Louis, Missouri: Saunders; 2015. p. 543-60. 


\section{3}

\section{Acute Myelogenous Leukemia (AML)}

\section{MICHELLE TO AND VALENTIN VILLATORO}

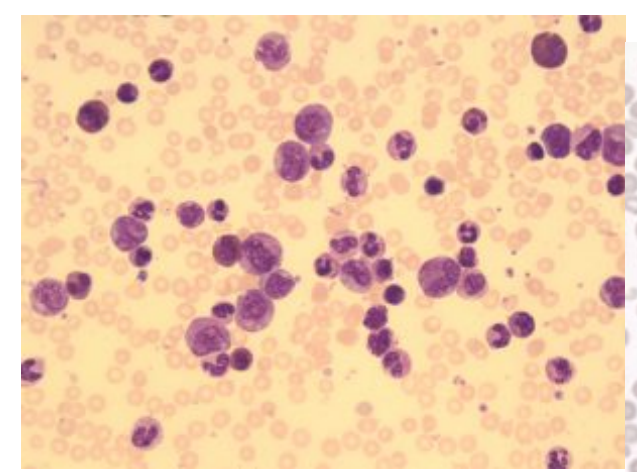

An image from a bone marrow smear showing an abundant amount of myeloid precursors and a few myeloblasts seen in a patient with acute myeloid leukemia. 50x oil immersion. From MLS Collection, University of Alberta, https://doi.org/10.7939/R32V2C R7N

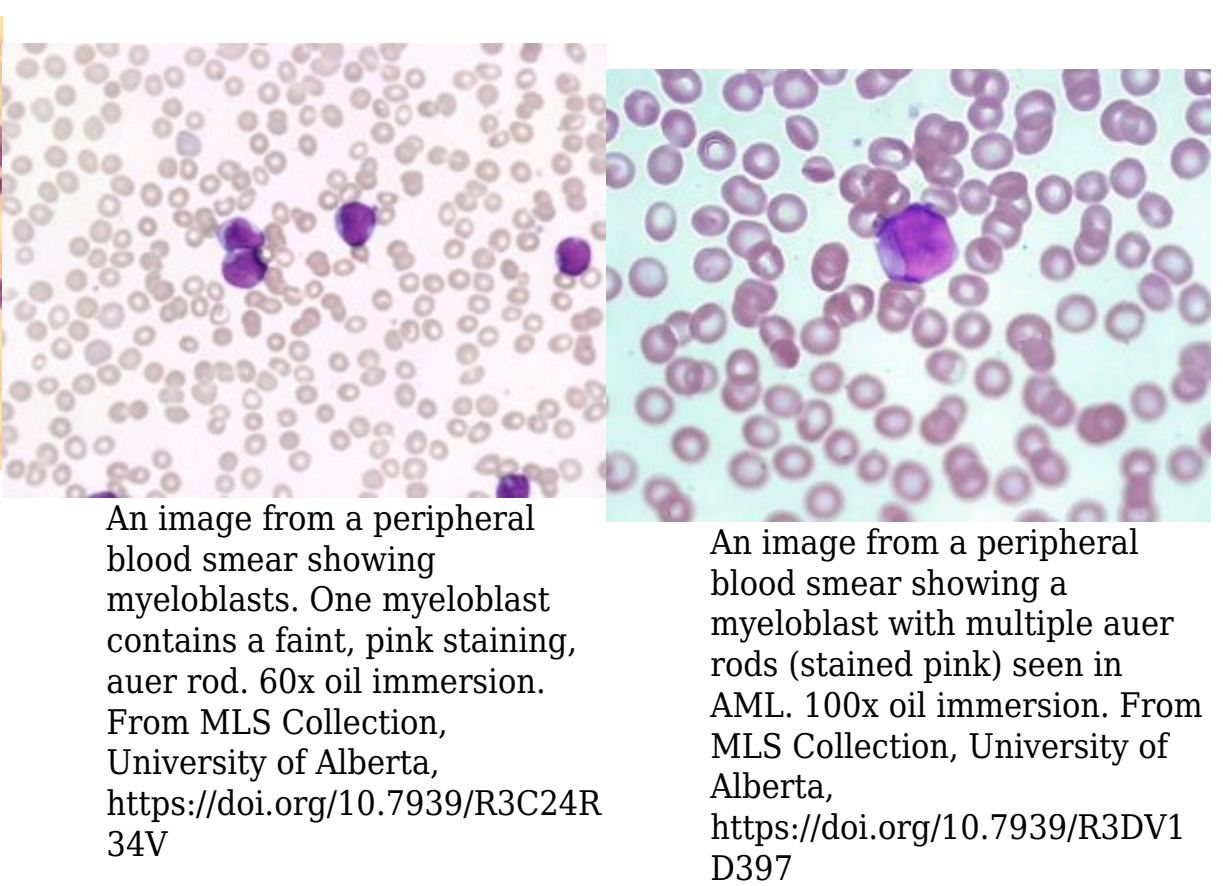

\section{WHO Classification (2008):}

As of 2008, acute myeloid leukemias have been classified into different subcategories based on the type of genetic abnormalities, type of myeloid cell type affected, and by cell characteristics: ${ }^{1}$

1. Acute myeloid leukemia with recurrent genetic abnormalities

2. Acute myeloid leukemia with myelodysplastic changes

3. Therapy related myeloid neoplasms

4. Acute myeloid leukemia, not otherwise specified (NOS)

5. Myeloid Sarcoma 
6. Myeloid Proliferations related to Down syndrome

7. Blastic plasmacytoid dendritic cell neoplasm

Affected Age: Adults. ${ }^{2}$

\section{Cells of myeloid lineage are affected: ${ }^{1}$}

- Myeloblast

- Monocytes

- Erythrocytes

- Megakaryocytes

- Dendritic cells

\section{AML Blasts Cell Features: ${ }^{3}$}

Size: Myeloblasts are usually larger compared to lymphoblasts and have a consistent appearance.

Nucleoli: Prominent, 1-4 present

Chromatin: Loose open chromatin

Cytoplasm: Often abundant and granules may be visible

Auer Rods: may be present (stained faint pink with Wright's stain)

Auer Rods are thought to be fused primary granules and are only found in myeloblasts. Presence of auer rods is distinctive of AML and can be used to differentiate the condition from ALL if it is present. ${ }^{1}$

\footnotetext{
Laboratory Results for AML: ${ }^{1,4,5}$
} 
CBC:

RBC: Decreased

WBC: Variable

PLT: Decreased

$\mathrm{Hb}$ : Decreased

RDW: Increased

\section{PBS:}

Myeloblasts \pm Auer rods

Macrocytic RBCs

May see hypogranular PLT, Giant PLT

Neutropenia (Can appear dysplastic)

May see Basophilia, Eosinophilia, Monocytosis
BM:

$\geq 20 \%$ Myeloblasts \pm Auer rods

Hypercellular

Decreased fat
Immunologic Markers:

Depending on the subgroup, cells may be positive for:

CD11b, CD13, CD14, CD33, CD34, CD117
Other Tests:

LD: Increased

Hyperuricemia

Hyperphosphatemia

Hypocalcemia

Hypokalemia

Cytogenetics

Cytochemistry

\section{References:}

1. Swerdlow SH, Campo E, Harris NL, Jaffe ES, Pileri SA, Stein H, et al. editors. WHO Classification of Tumours of Haematopoietic and Lymphoid Tissues Volume 2. 4th ed. International Agency for Research on Cancer (IARC); 2008.

2. McKenzie SB. Introduction to hematopoietic neoplasms. In: Clinical laboratory hematology. 3rd ed. New Jersey: Pearson; 2015. p. 424-45.

3. Gatter K, Cruz F, Braziel R. Introduction to leukemia and the acute leukemias. In: Clinical hematology and fundamentals of hemostasis. 5th ed. Philadelphia: F.A. Davis Company; 2009. p. 331-370.

4. Roquiz W, Gandhi P, Kini AR. Acute leukemias. In: Rodak's hematology clinical applications and principles. 5th ed. St. Louis, Missouri: Saunders; 2015. p. 543-60.

5. Bentley G, Leclair SJ. Acute Myeloid Leukemias. In: Clinical laboratory hematology. 3rd ed. New Jersey: Pearson; 2015. p. 500-21. 


\section{4}

\section{Acute Promyelocytic Leukemia (APL)}

\section{MICHELLE TO AND VALENTIN VILLATORO}

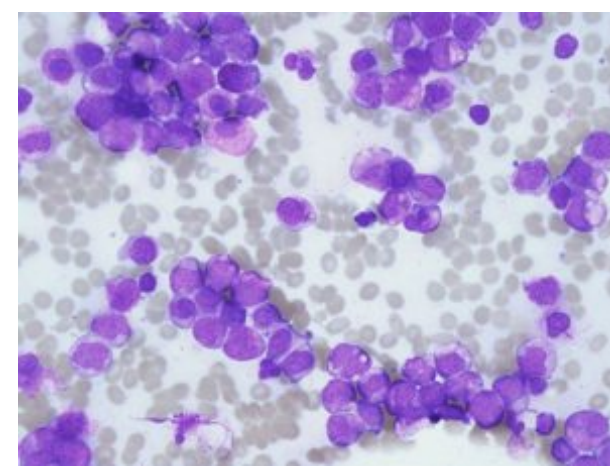

An image from a bone marrow smear demonstrating numerous myeloid precursors arrested at the promyelocyte stage, and cells with bundles of auer rods known as faggot cells in acute promyelocytic leukemia. 50x oil immersion. From MLS Collection, University of Alberta, https://doi.org/10.7939/R3WH2 DW4D
An image from a bone marrow smear showing faggot cells with bundles of auer rods seen in acute promyelocytic leukemia. 100x oil immersion. From MLS Collection, University of Alberta, https://doi.org/10.7939/R3N010 854

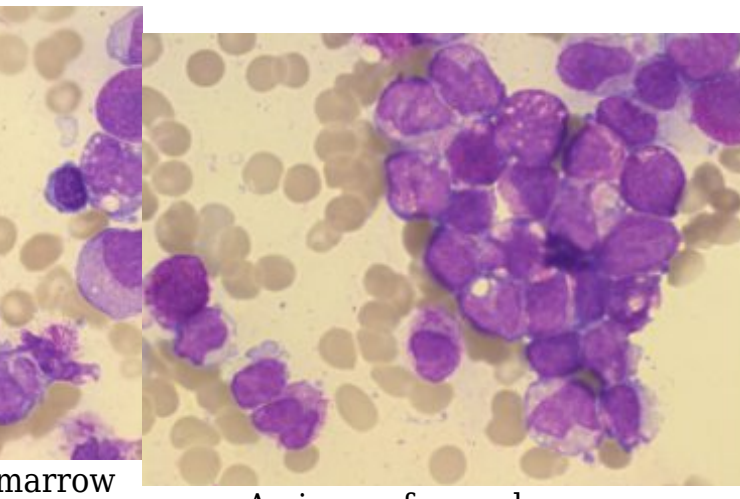

An image from a bone marrow smear showing faggot cells with bundles of auer rods seen in acute promyelocytic leukemia. 100x oil immersion. From MLS Collection, University of Alberta, https://doi.org/10.7939/R3H708 G10

Note: APL is a subtype of AML where the promyelocytes specifically are affected. It is classified under the "AML with recurrent genetic abnormalities" and is associated with a specific genetic abnormality: $\mathrm{t}(15 ; 17)(\mathrm{q} 22 ; \mathrm{q} 12) ;$ PML-RARA.

\section{Affected Age:}

Most often middle age adults, but APL can develop at any age, ${ }^{1,2}$ 
Promyelocyte

\section{Cell Description: ${ }^{1,2}$}

Nucleus: The shape of the nucleus is variable and can be bilobed, multilobed, indented, or folded. May demonstrate a typical "butterfly shape" appearance.

Cytoplasm: The hypergranular variant of APL is characterized by numerous promyelocytes with abundant abnormal, coarse, and dense granulation. The granules stain light pink to reddish-purple and heavily cover and obscure the nucleus of the cell. In the microgranular variant, the abnormal promyelocyte cells demonstrate a lack of granulation but often have abnormal bi-lobed nuclei.

Cells may contain characteristic multiple or bundles of auer rods (light pink) which the cells are then termed "Faggot cells."

The granules in the neoplastic promyelocytes have procoagulant activity. Because of this, Disseminated Intravascular Coagulation (DIC) is associated as a complication of APL. Coagulation studies including fibrinogen and DDimer measurement can aid in the diagnosis of DIC in these patients.

\section{References:}

1. Bentley G, Leclair SJ. Acute Myeloid Leukemias. In: Clinical laboratory hematology. 3rd ed. New Jersey: Pearson; 2015. p. 500-21.

2. Swerdlow SH, Campo E, Harris NL, Jaffe ES, Pileri SA, Stein H, et al. editors. WHO Classification of Tumours of Haematopoietic and Lymphoid Tissues Volume 2. 4th ed. International Agency for Research on Cancer (IARC); 2008. 


\section{5 \\ Cytochemical Testing}

\section{MICHELLE TO AND VALENTIN VILLATORO}

Cytochemistry involves staining cells in vitro to visualize certain cellular components that will help determine the lineage of the cell. After staining, cells are examined microscopically. ${ }^{1}$

\section{Myeloperoxidase (MPO)}

MPO is an enzyme that is found in the primary granules of all granulocytes and monocytes and not present in lymphocytes. MPO is useful for differentiating between ALL and AML blasts. ${ }^{2,3}$

\section{Results: ${ }^{2,3}$}

Granulocytes, Myeloblasts, Auer rods: Positive

Monocytes: Negative to weak positive

Lymphocytes: Negative

\section{Sudan Black B}

Stains lipids present in the primary and secondary granules of granulocytes and monocyte lysosomes.

Similar to MPO, it is useful for differentiating between AML and ALL but it is less specific. ${ }^{1-3}$ 


\section{Results: ${ }^{1-3}$}

Granulocytes, Myeloblasts: Positive

Monocytes: Negative to weakly positive

Lymphocytes: Negative

\section{Nonspecific Esterases (Alpha-napthyl acetate esterase)}

An enzymatic stain that is used to differentiate granulocytes from monocytes. The stain is considered nonspecific because other cells may also be stained. ${ }^{1-3}$

\section{Results: ${ }^{1-3}$}

Monocytes: Diffusely positive (Positivity can be inhibited by sodium fluoride)

Granulocytes: Negative

Lymphocytes: Negative (Except T lymphocytes which show focal positivity)

\section{Specific Esterase (Chloroacetate esterase)}

An enzymatic stain that is specific for granulocytes. ${ }^{1-3}$

\section{Results: ${ }^{1-3}$}

Granulocytes (Neutrophils), Myeloblasts, Auer rods: Positive 


\section{Periodic Acid Schiff (PAS)}

PAS stains glycogen related compounds. ${ }^{3}$ PAS is useful for the identification of lymphoid cells.

\section{Results: ${ }^{1}$}

Leukemic erythroblasts: Positive (normal erythroblasts are not positive)

Lymphoblasts: Block positivity

\section{Leukocyte Alkaline Phosphatase (LAP)}

LAP is an enzyme present in the secondary granules of neutrophils and not present in eosinophils or basophils. LAP is useful for distinguishing between chronic myelogenous leukemia (CML) from other conditions that show increased leukocyte counts. ${ }^{1}$

\section{Results: ${ }^{1}$}

CML: Low LAP score

Leukemoid Reactions: High LAP score 


\section{Acid Phosphatase}

An enzyme that is present in the lysosomes of normal leukocytes. ${ }^{1}$

\section{Results: $^{1}$}

T cell ALL: Positive

Hairy cells: Positive

Hairy cells also show positivity for tartrate resistant acid phosphatase (TRAP) whereas other cells would be inhibited by TRAP. ${ }^{1}$

\section{Terminal Deoxynucleotidyl transferase (TdT)}

TdT is a DNA polymerase found in immature cells. ${ }^{1}$ Results are useful in identifying lymphoblastic leukemias.

\section{Results: $^{1}$}

Immature lymphocytes (ALL): Positive

Table 1. Cytochemistry Staining for ALL and AML Subgroups. ${ }^{1-5}$ 


\begin{tabular}{|c|c|c|c|c|c|}
\hline $\begin{array}{l}\text { Acute Leukemia } \\
\text { Subgroup }\end{array}$ & MPO & Sudan Black B & $\begin{array}{l}\text { Nonspecific } \\
\text { Esterase }\end{array}$ & Specific Esterase & PAS \\
\hline ALL & - & - & \pm & - & Block + \\
\hline AML & + & + & - & + & \pm \\
\hline AMML & + & + & + & + & - \\
\hline AMoL & - & \pm & + & - & - \\
\hline AEL & + & + & \pm & + & + \\
\hline AMkL & - & - & \pm & + & + \\
\hline APL & + & + & \pm & + & - \\
\hline \multicolumn{3}{|c|}{$\begin{array}{l}\text { ALL = Acute lymphoblastic leukemia } \\
\text { AML = Acute myeloid leukemia } \\
\text { AMML = Acute myelomonocytic leukemia } \\
\text { AMoL = Acute monoblastic and monocytic leukemia } \\
\text { AEL = Acute Erythroid Leukemia } \\
\text { AMkL = Acute megakaryoblastic leukemia } \\
\text { APL = Acute promyelocytic leukemia }\end{array}$} & $\begin{array}{l}+=\text { Positive } \\
-=\text { Negative } \\
\pm=\text { Can be posit }\end{array}$ & r negative & \\
\hline
\end{tabular}

\section{References:}

1. McKenzie SB. Introduction to hematopoietic neoplasms. In: Clinical laboratory hematology. 3rd ed. New Jersey: Pearson; 2015. p. 424-45.

2. Roquiz W, Gandhi P, Kini AR. Acute leukemias. In: Rodak's hematology clinical applications and principles. 5th ed. St. Louis, Missouri: Saunders; 2015. p. 543-60.

3. Gatter K, Cruz F, Braziel R. Introduction to leukemia and the acute leukemias. In: Clinical hematology and fundamentals of hemostasis. 5th ed. Philadelphia: F.A. Davis Company; 2009. p. 331-370.

4. Bentley G, Leclair SJ. Acute Myeloid Leukemias. In: Clinical laboratory hematology. 3rd ed. New Jersey: Pearson; 2015. p. 500-21.

5. Swerdlow SH, Campo E, Harris NL, Jaffe ES, Pileri SA, Stein H, et al. editors. WHO Classification of Tumours of Haematopoietic and Lymphoid Tissues Volume 2. 4th ed. International Agency for Research on Cancer (IARC); 2008. 


\title{
76
}

\section{Flow Cytometry, Cytogenetics \& Molecular Genetics}

\author{
MICHELLE TO AND VALENTIN VILLATORO
}

\section{Classification of Leukemia}

The classification of Acute Leukemia relies on the use of a variety of laboratory results, including morphology, immunophenotyping, genetic features, and clinical features. Classification allows for appropriate disease management, treatment, prognosis, and monitoring to occur. The laboratory is crucial in this aspect. The following is a brief summary of the type of laboratory testing involved in the classification of Acute Leukemia in addition to what has already been discussed.

\section{Flow Cytometry}

Flow Cytometry, also known as immunophenotyping, is a technique that can be used to help determine a cell's lineage based on cell markers (e.g Cluster of Differentiation/CD Markers) present and the stage of maturation of a cell. ${ }^{1}$

\section{Principle:}

Monoclonal antibodies with fluorescent labels that are specific for the surface antigen of interest are incubated with the sample. Samples are taken up by the flow cytometer and injected into a stream of sheath fluid to allow cells to be positioned centrally, this process is called hydrodynamic focusing. A laser is directed at the cells and the bound antibodies fluoresce. Fluorescence detectors are used to

detect the fluorescence and a scatter graph is produced based on the antibodies bound. ${ }^{2}$ Other properties such as light scatter (in the forward and side direction) are combined with fluorescence intensity measurements to distinguish cell populations. 
Flow cytometry can be used to help determine what cells are present to help diagnose acute leukemias and other hematological disorders.

\section{Table 1. Common Surface Markers for Blood Cells. ${ }^{2}$}

\begin{tabular}{ll}
\hline Cell Lineage & Surface Markers \\
Immature Cells & CD34, CD117 \\
Granulocytes, Monocytes & CD13, CD14,CD15, CD33 \\
Erythrocytes & CD71, Glycophorin A \\
Megakaryocytes & CD41, CD42, CD61 \\
T Lymphocytes & CD2,CD3, CD4, CD5, CD7, CD8 \\
B Lymphocytes & CD19, CD20, CD22 \\
\hline
\end{tabular}

\section{Cytogenetics}

Cytogenetics involve the identification of abnormal karyotypes which may be characteristic to a related disorder. ${ }^{1}$

\section{Fluorescence In Situ Hybridization (FISH)}

FISH is a molecular method that is a cytogenetic tool that is used to detect chromosomal abnormalities such as translocations, deletions, inversion, and duplications. 3

The method involves using a fluorescently labelled DNA or RNA probe that is complementary to a specific target sequence. After denaturing double stranded DNA to single stranded DNA, the labelled probe is allowed to incubate and hybridize with the DNA. After incubation, the sample is washed to remove any unbound probes and then a counterstain is added to assist examination. Samples are examined with a fluorescent microscope to look for any chromosomal abnormalities in the cells. ${ }^{3}$ 


\section{Molecular Genetics}

Molecular genetics involve the use of molecular techniques to identify specific genetic sequences and mutations that can be characteristic for a diagnosis. ${ }^{1}$

\section{Polymerase Chain Reaction (PCR)}

PCR is commonly used to amplify a specific target sequence such a mutation. ${ }^{4}$

\section{References:}

1. McKenzie SB. Introduction to hematopoietic neoplasms. In: Clinical laboratory hematology. 3rd ed. New Jersey: Pearson; 2015. p. 424-45.

2. Czader M. Flow cytometric analysis in hematologic disorders. In: Rodak's hematology clinical applications and principles. 5th ed. St. Louis, Missouri: Saunders; 2015. p. 543-60.3. Vance GH. Cytogenetics. In: Rodak's hematology clinical applications and principles. 5th ed. St. Louis, Missouri: Saunders; 2015. p. 498-512.

4. Jackson CL, Mehta S. Molecular diagnostics in hematopathology. In: Rodak's hematology clinical applications and principles. 5th ed. St. Louis, Missouri: Saunders; 2015. p. 513-42. 


\section{XIII}

\section{WHITE BLOOD CELLS: MATURE LYMPHOID NEOPLASMS}




\section{7 \\ Introduction to Mature Lymphoid Neoplasms}

\section{MICHELLE TO AND VALENTIN VILLATORO}

These group of disorders are also known as lymphoproliferative disorders and involve the clonal proliferation of mature lymphocytes. ${ }^{1}$ The proliferation of these cells causes the formation of lymphomas and leukemias. ${ }^{2}$

As with acute leukemia, there are also a variety of factors that can lead to the development of these disorders: ${ }^{3}$

1. Acquired mutations leading to altered oncogene and tumor suppressor gene functions.

2. Inherited immunodeficiency syndromes that are associated with these neoplasms

3. Environmental factors that can lead to the development of neoplasms (e.g. viral and bacterial infections)

The 2008 WHO Classification categorizes the related disorders based on the type of cell that is involved (B or $\mathrm{T}$ cell). ${ }^{4}$

\section{List of Mature B cell Neoplasms as per WHO 2008: ${ }^{4}$}

Chronic lymphocytic leukemia

Hairy Cell Leukemia

Waldenstrom macroglobulinemia (lymphoplasmacytic lymphoma) 
Plasma cell neoplasms

Monoclonal gammopathy of undetermined significance (MGUS)

Plasma cell myeloma/multiple myeloma

Note: WHO 2008 lists additional disorders under mature B-cell neoplasms and as well has mature T-cell neoplasms. Only those listed above will be discussed in this eBook.

\section{References:}

1. Holmer LD, Bueso-Ramos CE. Chronic lymphocytic leukemia and related lymphoproliferative disorders. In: Clinical hematology and fundamentals of hemostasis. 5th ed. Philadelphia: F.A. Davis Company; 2009. p. 440-65.

2. Czader M. Mature lymphoid neoplasms. In: Rodak's hematology clinical applications and principles. 5th ed. St. Louis, Missouri: Saunders; 2015. p. 619-41.

3. Craig F. Mature lymphoid neoplasms. In: Clinical laboratory hematology. 3rd ed. New Jersey: Pearson; 2015. p. 535-56.

4. Swerdlow SH, Campo E, Harris NL, Jaffe ES, Pileri SA, Stein H, et al. editors. WHO Classification of Tumours of Haematopoietic and Lymphoid Tissues Volume 2. 4th ed. International Agency for Research on Cancer (IARC); 2008. 


\section{8}

Chronic Lymphocytic Leukemia (CLL)

\section{MICHELLE TO AND VALENTIN VILLATORO}

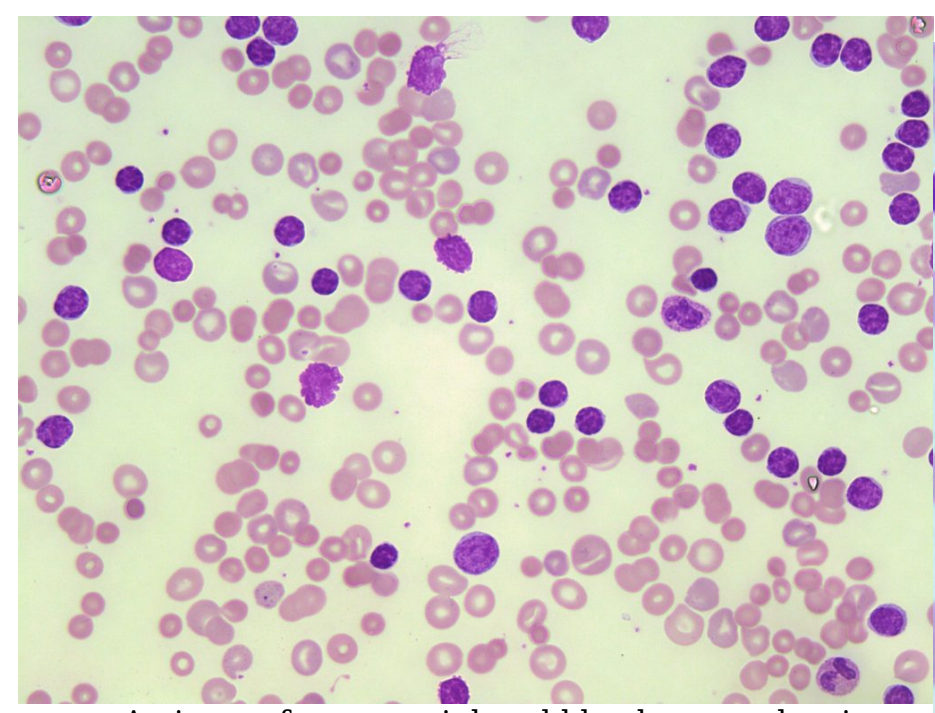

An image from a peripheral blood smear showing numerous small mature lymphocytes and smudge cells seen in a patient with CLL. 50X oil immersion. From MLS Collection, University of Alberta, https://doi.org/10.7939/R3SQ8QZ8C

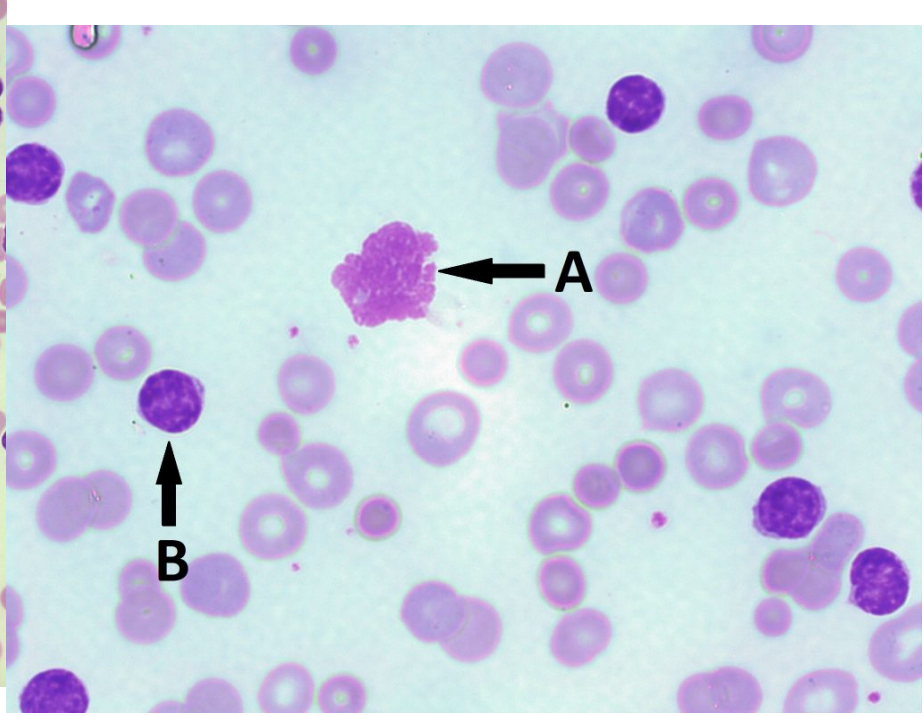

An image from a CLL peripheral blood smear showing a smudge cell (A) and mature small lymphocytes (B). 100x oil magnification. From MLS Collection, University of Alberta, https://doi.org/10.7939/https://doi.org/10.7939/R3D J58X9R

\section{Cell Features: ${ }^{1-4}$}

Abundant small mature small lymphocytes

Scant Cytoplasm

Condensed/clumped chromatin (often described as "soccer ball" or "parched earth" appearance)

\section{Cause: $:^{1-4}$}

A mature B cell neoplasm with no specific agent or cause. Cytogenetic findings show relation to trisomy 12 and other chromosomal deletions. 
Age group affected: Mainly older adults $>50$ years old. ${ }^{1,5,6}$

\section{Laboratory Features for CLL: ${ }^{1,2,6}$}

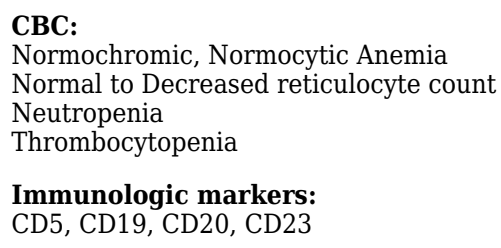

Normochromic, Normocytic Anemia

Normal to Decreased reticulocyte count

Neutropenia

Thrombocytopenia

Immunologic markers:

CD5, CD19, CD20, CD23

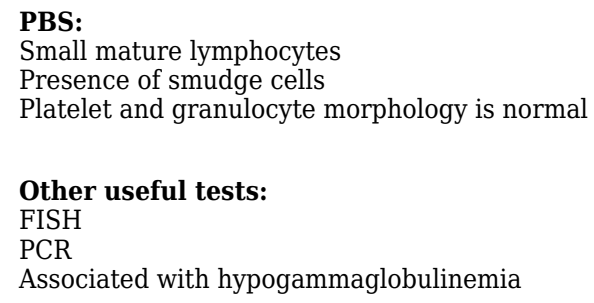

Small mature lymphocytes

Presence of smudge cells

Platelet and granulocyte morphology is normal

Other useful tests:

FISH

PCR

Associated with hypogammaglobulinemia

BM:

Lymphocytic infiltration, reduced numbers of normal hematopietic cells

\section{References:}

1. Holmer LD, Bueso-Ramos CE. Chronic lymphocytic leukemia and related lymphoproliferative disorders. In: Clinical hematology and fundamentals of hemostasis. 5th ed. Philadelphia: F.A. Davis Company; 2009. p. 440-65.

2. Czader M. Mature lymphoid neoplasms. In: Rodak's hematology clinical applications and principles. 5th ed. St. Louis, Missouri: Saunders; 2015. p. 619-41.

3. Kipps TJ, Stevenson FK, Wu CJ, Croce CM, Packham G, Wierda WG, et al. Chronic lymphocytic leukaemia. Nat Rev Dis Prim [Internet]. 2017 Jan 19 [cited 2018 Jun 27];3:16096. Available from: http://www.ncbi.nlm.nih.gov/pmc/articles/PMC5336551/

4. Swerdlow SH, Campo E, Harris NL, Jaffe ES, Pileri SA, Stein H, et al. editors. WHO Classification of Tumours of Haematopoietic and Lymphoid Tissues Volume 2. 4th ed. International Agency for Research on Cancer (IARC); 2008.

5. McKenzie SB. Introduction to hematopoietic neoplasms. In: Clinical laboratory hematology. 3rd ed. New Jersey: Pearson; 2015. p. 424-45.

6. Turgeon ML. Malignant myeloid and monocytic disorders and plasma cell dyscrasias. In: Clinical hematology: theory and procedures. 4th ed. Philadelphia, PA: Lippincott Williams \& Wilkins; 1999. p. 275-92. 


\section{9}

Hairy Cell Leukemia (HCL)

\section{MICHELLE TO AND VALENTIN VILLATORO}

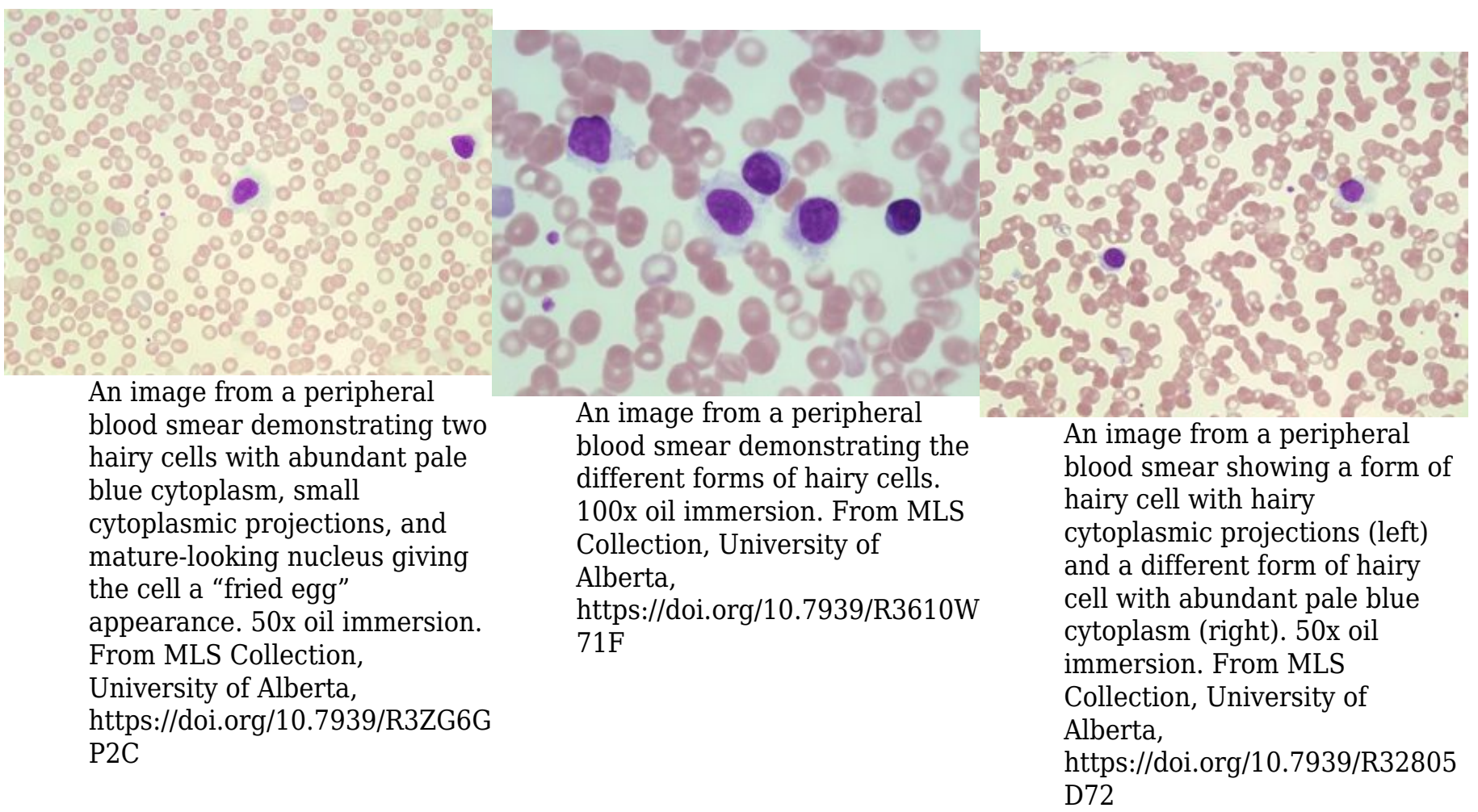

\section{Cell Features: $:^{1-4}$}

Two types of characteristic B lymphocyte morphologies can be seen in Hairy Cell Leukemia. Hairy cells are small to medium sized cells with either serrated cytoplasmic projections giving it a "hairy" appearance or more abundant pale blue cytoplasm giving it a "fried egg" appearance. The nucleus can be oval or indented, lacks nucleoli, and has an evenly stained mature chromatin patttern.

\section{Cause: $:^{1,5,6}$}

An indolent clonal mature B cell disorder has been associated with the BRAF -V600E mutation. 


\section{Age Group Affected: ${ }^{2,6}$}

Middle-aged adults (median age of 55 years).

\section{Laboratory Features for HCL: ${ }^{1,2,4,6}$}

\begin{tabular}{|c|c|c|}
\hline $\begin{array}{l}\text { CBCD: } \\
\text { Pancytopenia } \\
\text { Relative lymphocytosis }\end{array}$ & $\begin{array}{l}\text { Peripheral Blood Smear: } \\
\text { Hairy Cells ( } \pm \text { Fried egg appearance) }\end{array}$ & $\begin{array}{l}\text { Bone Marrow: } \\
\text { Dry Tap due to fibrosis (Aspirate) } \\
\text { Hypocellular }\end{array}$ \\
\hline $\begin{array}{l}\text { Immunologic markers: } \\
\text { CD19, CD20, CD22, CD25, CD123, Annexin A1 }\end{array}$ & $\begin{array}{l}\text { Other useful tests: } \\
\text { Tartrate-resistant acid phosphatase (TRAP) stain positive }\end{array}$ & \\
\hline
\end{tabular}

\section{References:}

1. Grever MR, Abdel-Wahab O, Andritsos LA, Banerji V, Barrientos J, Blachly JS, et al. Consensus guidelines for the diagnosis and management of patients with classic hairy cell leukemia. Blood [Internet]. 2016 Feb 2 [cited 2018 Jun 22];129(1):553-61. Available from: http://www.bloodjournal.org/cgi/doi/10.1182/blood-2016-01-689422

2. Turgeon ML. Malignant myeloid and monocytic disorders and plasma cell dyscrasias. In: Clinical hematology: theory and procedures. 4th ed. Philadelphia, PA: Lippincott Williams \& Wilkins; 1999. p. 275-92.

3. Swerdlow SH, Campo E, Harris NL, Jaffe ES, Pileri SA, Stein H, et al. editors. WHO Classification of Tumours of Haematopoietic and Lymphoid Tissues Volume 2. 4th ed. International Agency for Research on Cancer (IARC); 2008.

4. Czader M. Mature lymphoid neoplasms. In: Rodak's hematology clinical applications and principles. 5th ed. St. Louis, Missouri: Saunders; 2015. p. 619-41.

5. Troussard X, Cornet E. Hairy cell leukemia 2018: Update on diagnosis, risk-stratification, and treatment. Am J Hematol [Internet]. 2017 Dec 7 [cited 2018 Jun 25];92(12):1382-90. Available from: http://www.ncbi.nlm.nih.gov/pmc/articles/PMC5698705/

6. Jain P, Pemmaraju N, Ravandi F. Update on the biology and treatment options for hairy cell leukemia. Curr Treat Options Oncol [Internet]. 2014 Jun [cited 2018 Jun 27];15(2):187-209. Available from: 
http://www.ncbi.nlm.nih.gov/pmc/articles/PMC4198068/ 


\section{0}

\section{Waldenstrom Macroglobulinemia}

\section{MICHELLE TO AND VALENTIN VILLATORO}

\section{Features:}

Commonly characterized by an IgM monoclonal gammopathy. Increased igM may also result in cryoglobulinemia. Deposits of IgM into tissues and organs can result in intestinal dysfunction, clotting, and neuropathic complications. ${ }^{1}$

\section{Cause: ${ }^{1,2}$}

Genetic mutations

Inherited associations

Following viral infections (e.g. Hepatitis C).

Age Group Affected: $60-70$ years old, slightly more predominant in males. ${ }^{1,2}$

\section{Laboratory Results for Waldenstrom Macroglobulinemia: ${ }^{1,2}$}

CBC:

WBC: Increased (But lower than CLL)

Immunologic Markers: CD19, CD20, CD22, CD25, CD27, CD38, CD79a

\section{PBS:}

Increased number of small lymphocytes and maybe plasmacytoid lymphocytes.

Other Tests:

Monoclonal Paraprotein IgM: Positive

\section{BM:}

Infiltration of small lymphocytes Variable number of plasma cells and plasmacytoid lymphocytes. 


\section{References:}

1. Swerdlow SH, Campo E, Harris NL, Jaffe ES, Pileri SA, Stein H, et al. editors. WHO Classification of Tumours of Haematopoietic and Lymphoid Tissues Volume 2. 4th ed. International Agency for Research on Cancer (IARC); 2008.

2. Yun S, Johnson AC, Okolo ON, Arnold SJ, McBride A, Zhang L, et al. Waldenström Macroglobulinemia: Review of Pathogenesis and Management. Clin Lymphoma, Myeloma Leuk [Internet]. 2017 May 7 [cited 2018 Jun 27];17(5):252-62. Available from: http://www.ncbi.nlm.nih.gov/pmc/articles/PMC5413391/ 


\section{1 \\ Monoclonal Gammopathy of \\ Undetermined Significance (MGUS)}

MICHELLE TO AND VALENTIN VILLATORO

\section{Features:}

MGUS is characterized has having an increase in serum M protein, clonal plasma cells, a lack of CRAB symptoms (hyperCalcemia, Renal failure, Anemia, or lytic Bone lesions), and no diagnosis of any other B cell lymphoproliferative disorder. ${ }^{1,2}$

Patients are asymptomatic and present with no other physical abnormalities. ${ }^{1,3}$

\section{Cause:}

No specific cause has been linked to the development of MGUS. ${ }^{1}$

Age Group Affected: $>50$ years old. ${ }^{1,3}$

\section{Laboratory Results for MGUS: ${ }^{1,2}$}

\section{BM:}

Aspirates:

Increased Plasma cells $(<10 \%)$

Biopsies:

Slightly increased numbers of plasma cells

with minimal morphological abnormalities

\section{Immunologic Markers:}

CD19, CD38, CD138

\section{Other Tests:}

Protein electrophoresis

Immunofixation

Flow cytometry

FISH 


\section{References:}

1. Swerdlow SH, Campo E, Harris NL, Jaffe ES, Pileri SA, Stein H, et al. editors. WHO Classification of Tumours of Haematopoietic and Lymphoid Tissues Volume 2. 4th ed. International Agency for Research on Cancer (IARC); 2008.

2. Craig F. Mature lymphoid neoplasms. In: Clinical laboratory hematology. 3rd ed. New Jersey: Pearson; 2015. p. 535-56.

3. Rajkumar SV. Multiple myeloma: 2016 update on diagnosis, risk-stratification, and management. Am J Hematol [Internet]. 2016 Jul [cited 2018 Jun 27];91(7):719-34. Available from: http://www.ncbi.nlm.nih.gov/pmc/articles/PMC5291298/ 


\section{2}

\section{Plasma Cell Myeloma (Multiple Myeloma)}

\section{MICHELLE TO AND VALENTIN VILLATORO}

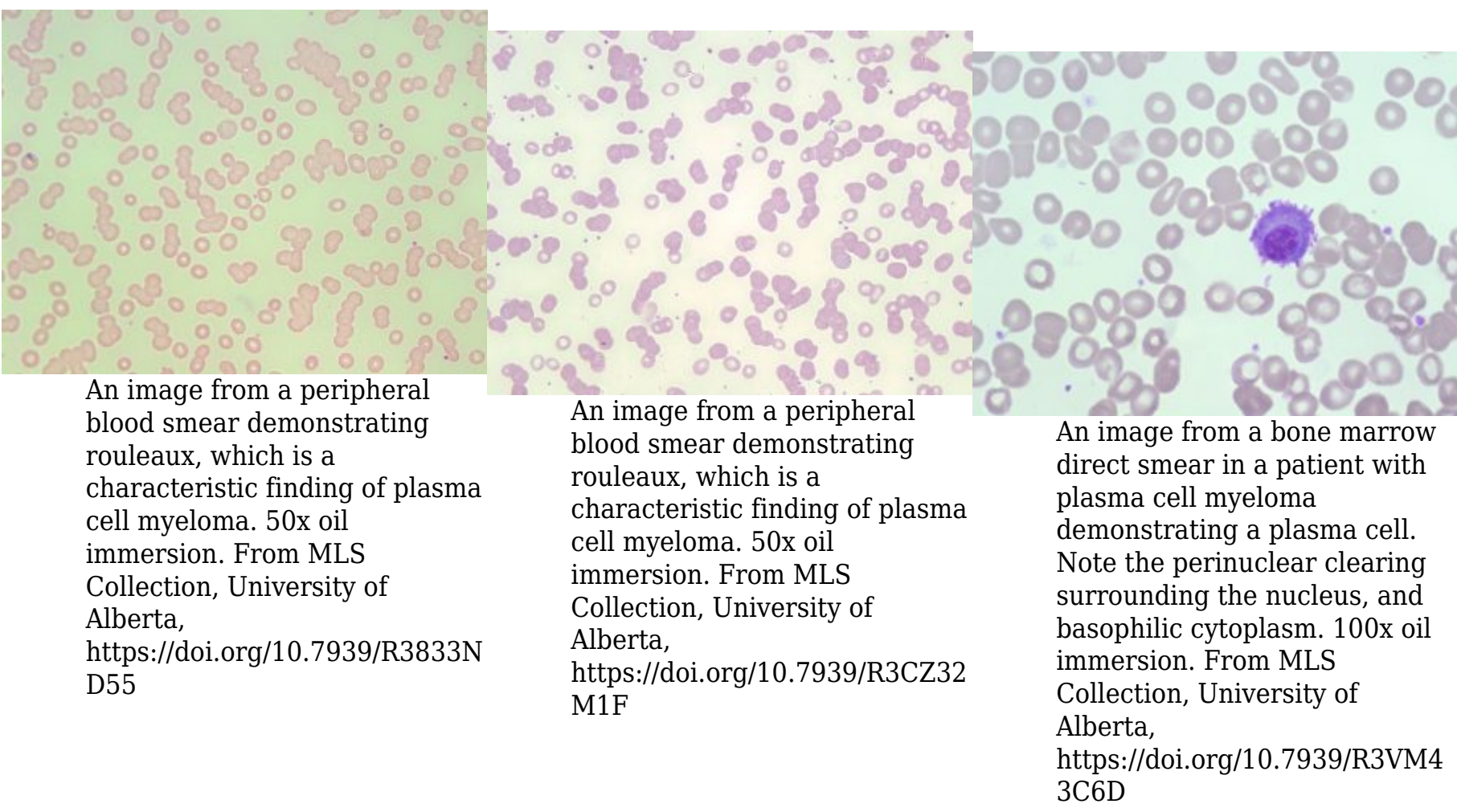

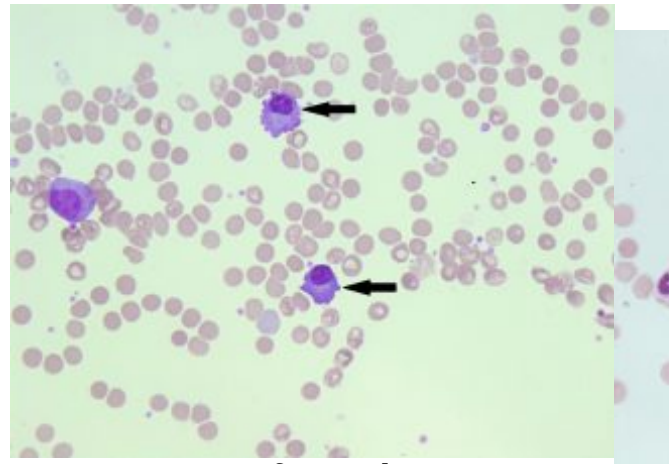

An image from a bone marrow direct smear from a patient with plasma cell myeloma demonstrating two plasma cells
An image from a peripheral blood smear demonstrating rouleaux, which is a characteristic finding of plasma cell myeloma. 50x oil immersion. From MLS Collection, University of Alberta https://doi.org/10.7939/R3CZ32 M1F

Alps://doi.org/10.7939/R3VM4

3C6D

An image from a bone marrow plasma cell myeloma demonstrating a plasma cell. Note the perinuclear clearing surrounding the nucleus, and basophilic cytoplasm. 100x oil immersion. From MLS Collection, University of Alberta, 
(indicated by arrows). 50x oil immersion. From MLS Collection, University of Alberta, https://doi.org/10.7939/R3348G $\mathrm{X} 60$ round globules (Russell bodies). Mott cells may also be seen in plasma cell myeloma bone marrow smears. 60X oil immersion. From MLS Collection, University of Alberta, https://doi.org/10.7939/R3RV0D G30 round globules (Russell bodies). Mott cells may be seen in plasma cell myeloma bone marrow smears. 60X oil immersion. From MLS Collection, University of Alberta, https://doi.org/10.7939/R31C1T X1V

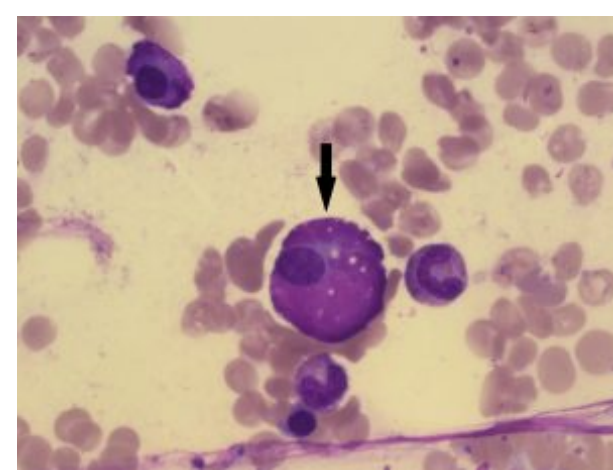

An image from a bone marrow direct smear from a patient with plasma cell myeloma demonstrating a large plasma cell variant known as a flame cell (indicated by an arrow). 100x oil immersion. From MLS Collection, University of Alberta, https://doi.org/10.7939/R3CF9J N7P

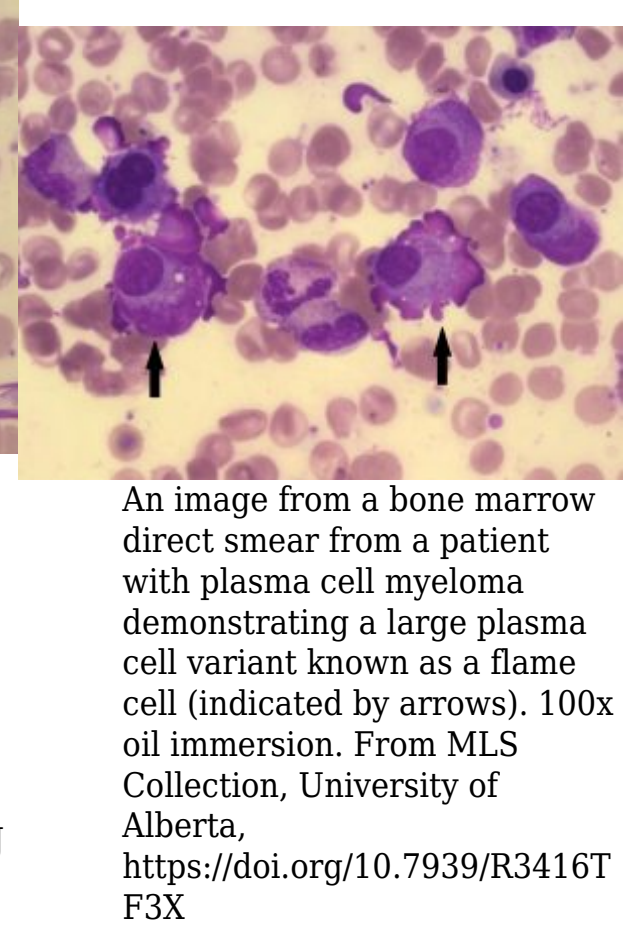

\section{Features:}

This disorder is characterized by an increase in M protein (monoclonal gammopathy) in the serum and/or urine with the presence of clonal plasma cells in the bone marrow. ${ }^{1}$

Unlike MGUS, patients with plasma cell myeloma often present with CRAB symptoms (hyperCalcemia, Renal failure, Anemia, and lytic Bone lesions). Additional features include osteolytic bone lesions without new bone formation. ${ }^{1,2}$ Some patients may be asymptomatic (smoldering multiple myeloma) but other findings of plasma cell myeloma may still be found. ${ }^{1,3}$ 
Due to bone damage, extramedullary hematopoiesis is a common finding. ${ }^{1}$

\section{Cause:}

Most cases of plasma cell myeloma have developed from MGUS. ${ }^{2}$

Other causes include infections, exposure to toxic substances, and other chronic diseases which may result in a long term antigenic stimulation. ${ }^{1}$

Cytogenetic abnormalities have been found to be associated with the development of multiple myeloma. ${ }^{3}$

Age Group Affected: >50 years old, more common in males. ${ }^{1}$

\section{Plasma Cell Morphology:}

Aside from the characteristic appearance of plasma cells, morphologic variants of plasma cells are often seen in Plasma Cell Myeloma. These include bi-lobed plasma cells, flame cells, and mott cells.

\section{Flame Cells:}

A reactive plasma cell that has reddish-purple cytoplasms. Colour of the cytoplasm is caused by glycoprotein and ribosomes. The presence of flame cells has been associated with IgA multiple myeloma. ${ }^{4}$

\section{Mott Cells:}

Are plasma cells with multiple round inclusions in the cytoplasm. The inclusions are termed "Russell bodies" and are composed of immunoglobulins. $^{3}$ 


\section{Laboratory Results for Plasma Cell Myeloma: ${ }^{1,2}$}

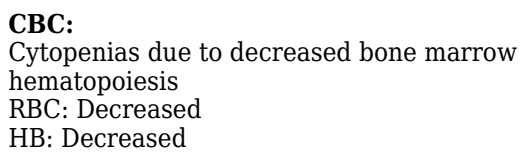

Immunologic Markers:

CD38, CD79a, CD138

\section{PBS:}

Rouleaux formation (Due to M protein)

Rare circulating plasma cells

Normocytic

Normochromic

\section{BM:}

Lytic regions

Plasmacytosis (>10\%)

Bi-lobed plasma cells, Flame cells, and/or Mott cells may be seen.

Biopsy: interstitial clusters of plasma cells Aspirates: shows various heterogeneous forms of plasma cells in aggregates or sheets.

\section{Reactive Plasmacytosis:}

An increase in the number plasma cells and immunoglobulins can also be the result of a non-malignant condition. Bacterial and viral infections (e.g infections mononucleosis, tuberculosis) can evoke a strong antigenic response and lead to an increase in plasma cells in the peripheral blood. ${ }^{4}$ The reactive process should NOT be confused with plasma cell myeloma.

Unlike plasma cell myeloma, there are no findings of CRAB symptoms or clonal plasma cells in the bone marrow. Plasma cells may be increased in the bone marrow, but not above $10 \%$. An increase in $M$ proteins and plasma cells (outside the bone marrow) may be found. ${ }^{3}$

\section{References:}

1. Swerdlow SH, Campo E, Harris NL, Jaffe ES, Pileri SA, Stein H, et al. editors. WHO Classification of Tumours of Haematopoietic and Lymphoid Tissues Volume 2. 4th ed. International Agency for Research on Cancer (IARC); 2008. 
2. Rajkumar SV. Multiple myeloma: 2016 update on diagnosis, risk-stratification, and management. Am J Hematol [Internet]. 2016 Jul [cited 2018 Jun 27];91(7):719-34. Available from: http://www.ncbi.nlm.nih.gov/pmc/articles/PMC5291298/

3. Craig F. Mature lymphoid neoplasms. In: Clinical laboratory hematology. 3rd ed. New Jersey: Pearson; 2015. p. 535-56.

4. Beglinger SS. Nonmalignant lymphocyte disorders. In: Clinical laboratory hematology. 3rd ed. New Jersey: Pearson; 2015. p. 409-24. 
XIV

WHITE BLOOD CELLS:

MYELOPROLIFERATIVE NEOPLASMS

(MPN) 


\section{3 \\ Introduction to Myeloproliferative \\ Neoplasms (MPNs)}

MICHELLE TO AND VALENTIN VILLATORO

MPNs are a group of clonal disorders that involve the proliferation and accumulation of one or more myeloid cell lines (erythrocytes, granulocytes, or platelets). These disorders are caused by genetic mutations in hematopoietic stem cells. ${ }^{1,2}$

MPNs are commonly seen in middle age adults but some may occur during childhood. ${ }^{1}$

The 2008 WHO classification system lists the following disorders under this category: ${ }^{1}$

Chronic Myelogenous Leukemia (CML)

Polycythemia Vera (PV)

Essential Thrombocytopenia (ET)

Primary Myelofibrosis (PMF)

Note: WHO 2008 lists additional disorders under MPNs but only the ones listed above will be discussed in this eBook.

\section{References:}

1. Swerdlow SH, Campo E, Harris NL, Jaffe ES, Pileri SA, Stein H, et al. editors. WHO Classification of 
Tumours of Haematopoietic and Lymphoid Tissues Volume 2. 4th ed. International Agency for Research on Cancer (IARC); 2008.

2. Randolph TR. Myeloproliferative Neoplasms. In: Clinical laboratory hematology. 3rd ed. New Jersey: Pearson; 2015. p. 450-78. 


\section{4}

\section{Chronic Myelogenous Leukemia (CML)}

\section{MICHELLE TO AND VALENTIN VILLATORO}

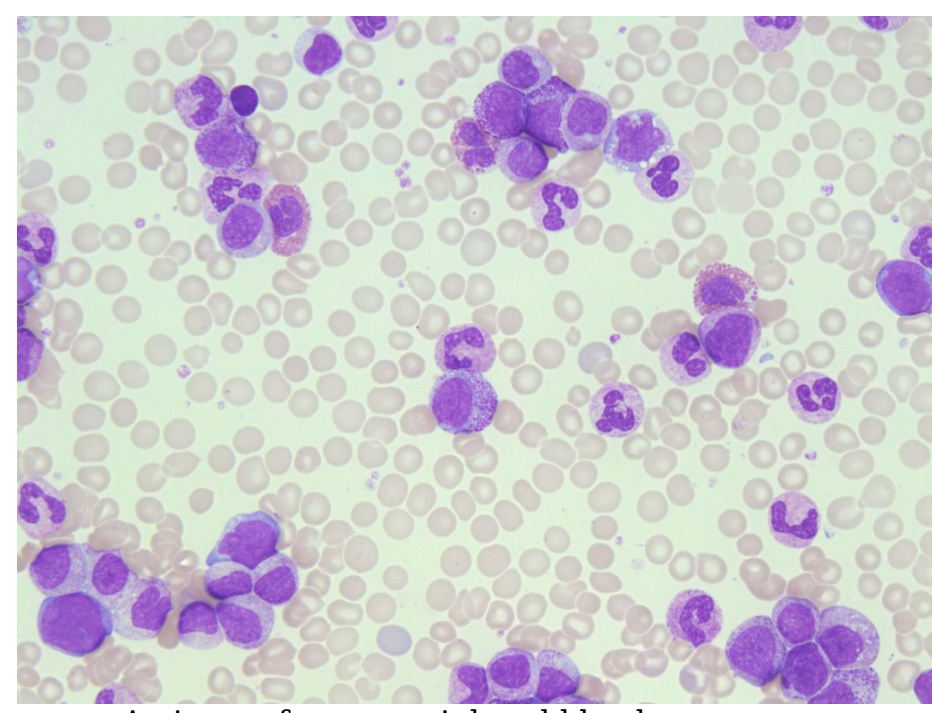

An image from a peripheral blood smear demonstrating myeloid precursors and a few blasts seen in chronic myelogenous leukemia. 50x oil immersion. From MLS Collection, University of Alberta, https://doi.org/10.7939/R3NZ8155H

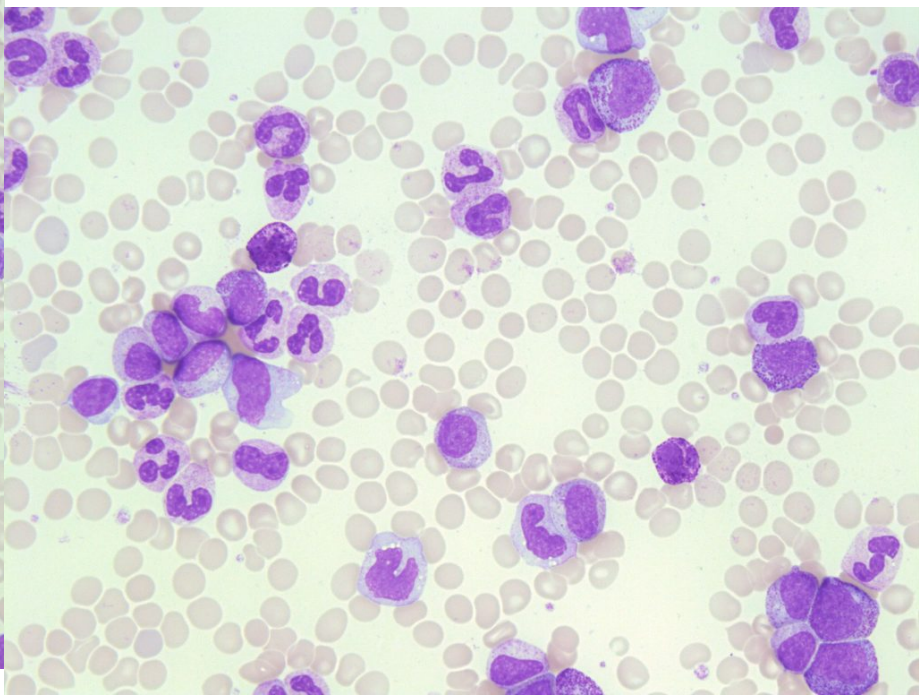

An image from a peripheral blood smear demonstrating a neutrophilia and myeloid precursors seen in CML. 500x oil immersion. From MLS Collection, University of Alberta, https://doi.org/10.7939/R3SQ8QZ9V

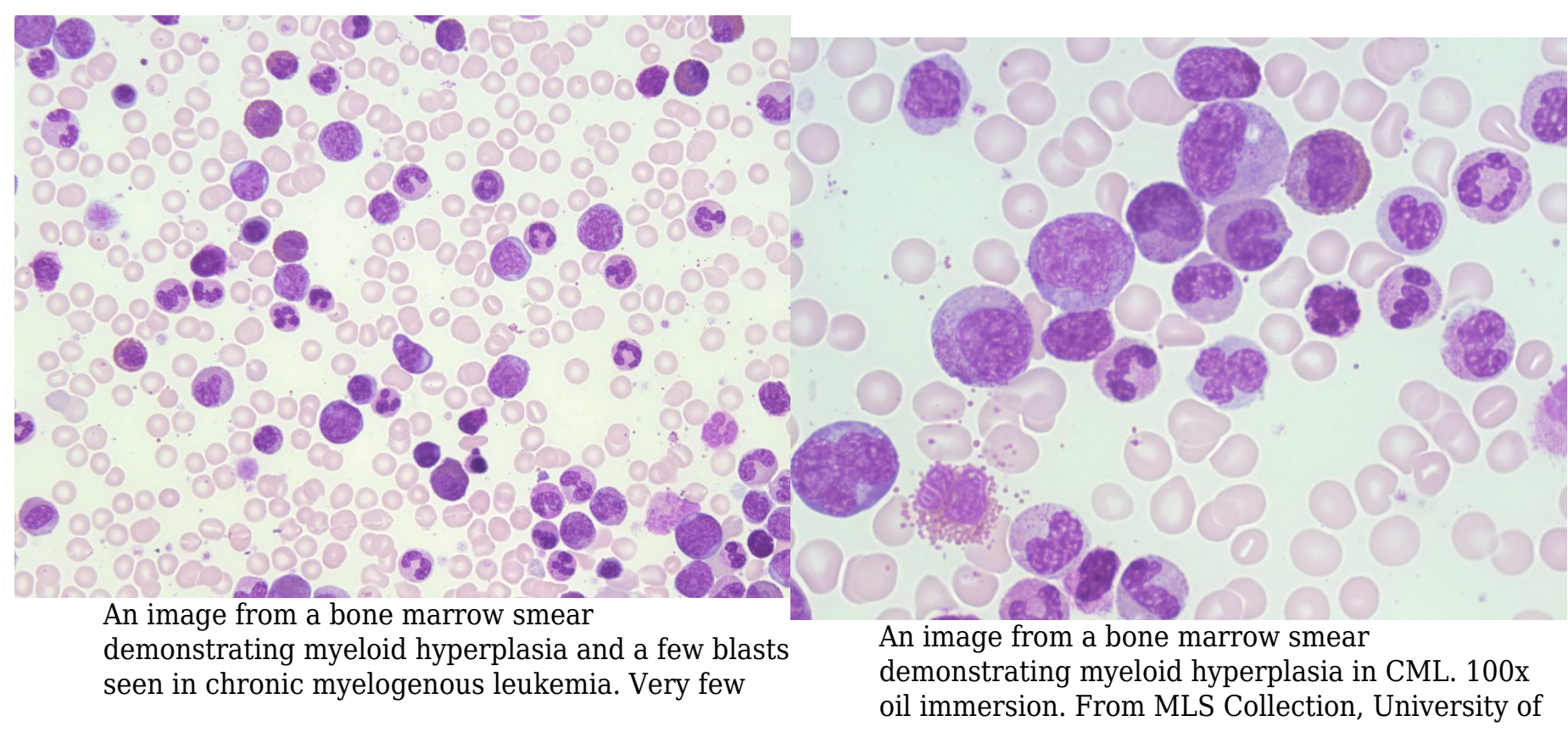


erythroid precursors are present. 50x oil immersion. From MLS Collection, University of Alberta, https://doi.org/10.7939/R38P5VR48
Alberta, https://doi.org/10.7939/R34X54Z0H

Affected Cell Line: Myeloid cell line (platelets and granulocytes are increased, however granulocyte production is most prominent). ${ }^{1,2}$

Mutation: Philadelphia Chromosome, $\mathrm{t}(9 ; 22)$, resulting in the $B C R-A B L 1$ fusion gene. ${ }^{3}$ The gene is characterized by a translocation between chromosomes 9 and 22 which is expressed as $t(9 ; 22){ }^{1}$

Age Group Affected: Seen commonly in middle aged adults, 46 to 53 years old. ${ }^{1}$

\section{Clinical Features:}

The onset of CML is insidious and in some patients may be asymptomatic. ${ }^{3}$ Other patients may have complications associated with frequent infections, infiltration of leukocytes, bleeding, weight loss, fever, fatigue, and anemia. ${ }^{1,4}$

Extramedullary hematopoiesis may occur, resulting in organomegaly. ${ }^{1}$

\section{The course of CML occurs in three phases:}

\section{Chronic Phase}

Peripheral blood: leukocytosis (usually $>100 \times 10^{9} / \mathrm{L}$ ), thrombocytosis (Up to $>1000 \times 10^{9} / \mathrm{L}$ ). ${ }^{3}$

Bone Marrow: hypercellularity due to increased granulopoiesis. Megakaryocytes are increased and may appear small and hypolobulated. ${ }^{3}$

\section{Accelerated Phase}


The bone marrow is hypercellular and often myelodysplastic features are seen. Additionally, there is an increased number of myeloblasts, and a dropping platelet count resulting in thrombocytopenia. Total white blood cell count continues to increase. ${ }^{3,4}$

\section{Blast Phase (Acute Leukemia)}

CML has transformed into an acute leukemia, either ALL or AML, and prognosis becomes poor even with treatment. ${ }^{4}$

Blast Phase is diagnosed when either: Bone marrow shows $\geq 20 \%$ blasts or when extramedullary blast proliferation is present. $^{3,4}$

\section{Laboratory Findings for CML: ${ }^{1,3,4}$}

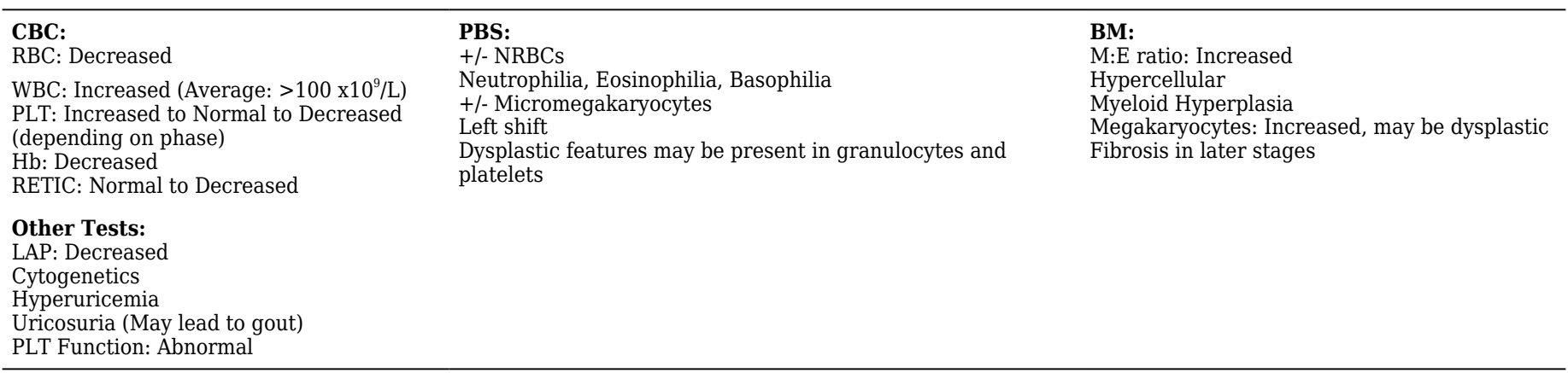

\section{Leukemoid Reaction}

A leukemoid reaction is a response to different stress events such as infections, inflammation, hemorrhage, or other malignant disorders that has a similar presentation to CML where there is an increase in the number of white blood cells and a left shift. ${ }^{4,5}$

A leukemoid reaction should NOT be confused with CML. 


\section{Table 1. Comparison of CML and Leukemoid Reaction. ${ }^{4,5}$}

\begin{tabular}{lll}
\hline Laboratory Finding & CML & Leukemoid Reaction \\
\hline PBS & Left shift (Very Immature) & Left shift (mild) \\
& Neutrophilia & Neutrophilia \\
& Eosinophilia & Absent eosinophilia \\
& Basophilia & Absent Basophilia \\
& Dysplastic Features & Toxic changes are often present
\end{tabular}

\begin{tabular}{lll}
\hline WBC & $20-500 \times 10^{9} / \mathrm{L}$ & Rarely $>60 \times 10^{9} / \mathrm{L}$ \\
\hline PLT & Increased & Normal \\
\hline Anemia & Present & Absent \\
\hline LAP Score & Low & High \\
\hline Chromosomal Abnormality & Philadelphia Chromosome/BCR-ABL1 & None
\end{tabular}

\section{References:}

1. Randolph TR. Myeloproliferative neoplasms. In: Rodak's hematology clinical applications and principles. 5th ed. St. Louis, Missouri: Saunders; 2015. p.561-90.

2. Schaub CR. Chronic Myeloproliferative disorders I: chronic myelogenous leukemia. In: Clinical hematology and fundamentals of hemostasis. 5th ed. Philadelphia: F.A. Davis Company; 2009. p. 371-84.

3. Swerdlow SH, Campo E, Harris NL, Jaffe ES, Pileri SA, Stein H, et al. editors. WHO Classification of Tumours of Haematopoietic and Lymphoid Tissues Volume 2. 4th ed. International Agency for Research on Cancer (IARC); 2008.

4. Randolph TR. Myeloproliferative neoplasms. In: Clinical laboratory hematology. 3rd ed. New Jersey: Pearson; 2015. p. 450-78.

5. Bain BJ. Disorders of white cells. In: Blood cells: a practical guide [Internet]. 5th ed. Chichester, UK: John Wiley \& Sons, Ltd; 2015 [cited 2018 Jul 10]:416-81. Available from: http://doi.wiley.com/10.1002/9781118817322 


\section{5 \\ Polycythemia Vera (PV)}

\section{MICHELLE TO AND VALENTIN VILLATORO}

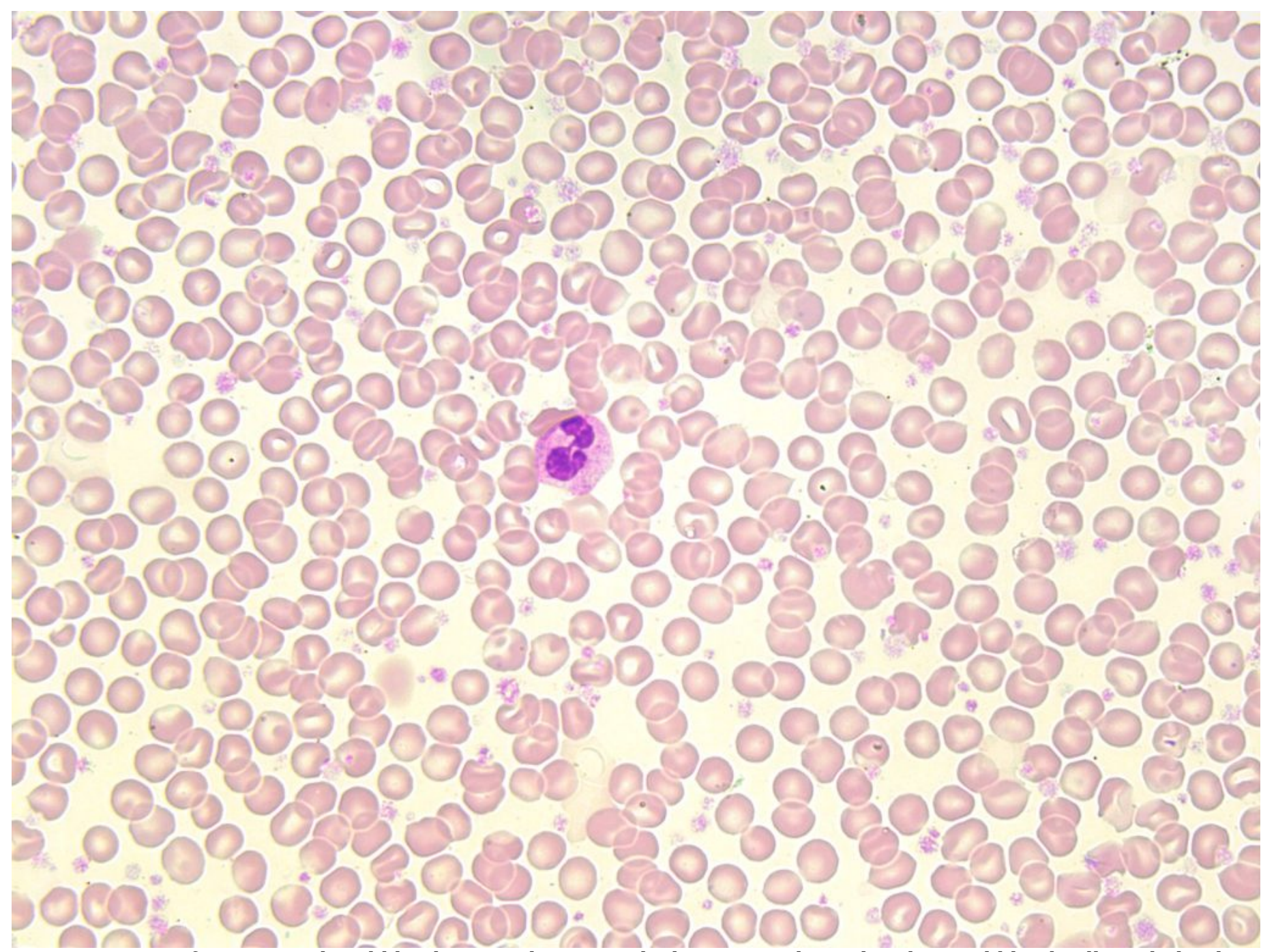

An image from a peripheral blood smear showing a thick smear with an abundant red blood cells and platelets often seen in polycythemia vera, 100x oil immersion. From MLS Collection, University of Alberta, https://doi.org/10.7939/R3WH2DW3X

Affected Cell Line: Mainly erythrocytes, though tri-lineage growth ("panmyelosis") is seen in the bone marrow. ${ }^{1,2}$ 


\section{Mutation:}

JAK 2 exon 12 and JAK 2 V617F gene mutations have been associated with PV. ${ }^{1,3}$

Age Group Affected: Average age of diagnosis is 60 years old. ${ }^{3}$

\section{Features:}

PV involves the proliferation of erythrocytes independent of normal erythropoiesis regulating mechanisms (e.g. erythropoietin). There is also an a proliferation of granulocytes and megakaryocytes (resulting in "panmyelosis") but the proliferation of erythrocytes is most prominent..$^{3-5}$

Unlike CML, PV does not readily transform into acute leukemia but may result in fibrosis over time. ${ }^{3}$ Splenomegaly is commonly seen.

\section{Laboratory Findings for PV: $:^{2,4,5}$}

\section{CBC:}

RBC: Increased

WBC: Increased

PLT: Increased

$\mathrm{Hb}$ : Increased

Hct: Increased

MCV: Increased

RETIC: Normal to increased
PBS:

RBCs are normochromic/normocytic, though iron stores may be exhausted, leading to hypo/micro RBCs

PBS appears crowded with RBCs (thick smears are due to the elevated Hct) A left shift and basophilia may be seen
BM:

M:E ratio: Normal to decreased

Hypercellular due to increased proliferation in all cell lines

Megakaryocytes are increased in number and may be enlarged and exhibit lobulated nuclei

Iron stores: decreased to absent

Other Tests:

Erythropoietin: Low or normal 


\section{Secondary Polycythemia}

Secondary polycythemia is a condition that occurs when there is an increased production of erythrocytes due an increased level of erythropoietin. Bone marrow shows an erythroid hyperplasia. ${ }^{5}$

Causes include: Hypoxia, Inappropriate use of erythropoietin, Familial polycythemia, neonatal polycythemia. ${ }^{5}$

\section{Relative Polycythemia}

Polycythemia that occurs due to a decrease in plasma volume, resulting in an elevated hematocrit, RBC count, and hemoglobin. There is no actual increased production of erythrocytes. ${ }^{5}$ The decrease in plasma volume is often the result of dehydration.

Hemoglobin and hematocrit appear increased but other CBC parameters such as white blood cell and platelet counts are normal. The bone marrow is also normal in terms of iron stores, cellularity and number of megakaryocytes. ${ }^{5}$

Table 1. Comparison between the different Polycythemias. ${ }^{5}$ 


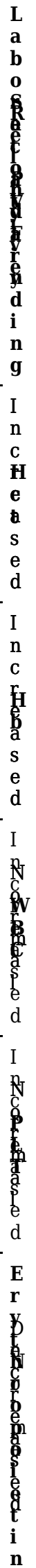




\section{References:}

1. Choi CW, Bang S-M, Jang S, Jung CW, Kim H-J, Kim HY, et al. Guidelines for the management of myeloproliferative neoplasms. Korean J Intern Med [Internet]. 2015 Nov 30 [cited 2018 Jul 9];30(6):771-88. Available from: http://kjim.org/journal/view.php?doi=10.3904/kjim.2015.30.6.771

2. Schaub CR. Chronic Myeloproliferative disorders I: chronic myelogenous leukemia. In: Clinical hematology and fundamentals of hemostasis. 5th ed. Philadelphia: F.A. Davis Company; 2009. p. 371-84.

3. Swerdlow SH, Campo E, Harris NL, Jaffe ES, Pileri SA, Stein H, et al. editors. WHO Classification of Tumours of Haematopoietic and Lymphoid Tissues Volume 2. 4th ed. International Agency for Research 
on Cancer (IARC); 2008.

4. Randolph TR. Myeloproliferative neoplasms. In: Rodak's hematology clinical applications and principles. 5th ed. St. Louis, Missouri: Saunders; 2015. p.561-90.

5. Randolph TR. Myeloproliferative neoplasms. In: Clinical laboratory hematology. 3rd ed. New Jersey: Pearson; 2015. p. 450-78. 


\section{6}

\section{Essential Thrombocythemia (ET)}

\section{MICHELLE TO AND VALENTIN VILLATORO}

An interactive or media element has been excluded from this version of the text. You can view it online here: https://pressbooks.library.ualberta.ca/mlsci/?p=757

Image of peripheral blood smears showing a giant platelet (center) and an increase in the number of platelets seen in Essential Thrombocythemia. From MLS Collection, University of Alberta.

Image 1: 50x oil immersion. https://doi.org/10.7939/R3J09WK51

Image 2: 60x oil immersion. https://doi.org/10.7939/R3X63BM52

Affected Cell Line: Megakaryocytes, Platelets. ${ }^{1,2}$

Mutation: JAK 2 V617F, CALR, and MPL gene mutations. ${ }^{1,3}$

Age Group Affected: Diagnosed most commonly at 50-60 years old. ${ }^{1}$

\section{Clinical Features:}

Most patients are asymptomatic and present with a platelet count of $\geq 450 \times 10^{9} / \mathrm{L} .{ }^{1}$ Thrombosis, vascular occlusion, and bleeding problems are the most commonly associated complications. Despite having abundant platelets, they are often dysfunctional. 


\section{Laboratory Findings for ET: ${ }^{1,4,5}$}

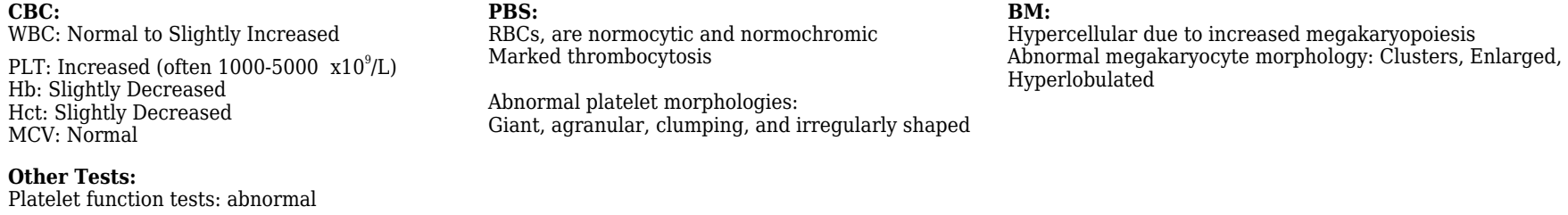

\section{Reactive Thrombocytosis}

A non-malignant condition that involves an increased platelet count secondary to other conditions that result in an increase in platelet production. It is associated with infections and inflammatory processes. ${ }^{5}$

Reactive thrombocytosis can be differentiated from essential thrombocythemia by looking at the platelet count. Platelet count rarely reaches $>1000 \times 10^{9} / \mathrm{L}$ and platelet function tests are normal. ${ }^{5}$

\section{References:}

1. Swerdlow SH, Campo E, Harris NL, Jaffe ES, Pileri SA, Stein H, et al. editors. WHO Classification of Tumours of Haematopoietic and Lymphoid Tissues Volume 2. 4th ed. International Agency for Research on Cancer (IARC); 2008.

2. Schaub CR. Chronic Myeloproliferative disorders I: chronic myelogenous leukemia. In: Clinical hematology and fundamentals of hemostasis. 5th ed. Philadelphia: F.A. Davis Company; 2009. p. 371-84.

3. Choi CW, Bang S-M, Jang S, Jung CW, Kim H-J, Kim HY, et al. Guidelines for the management of myeloproliferative neoplasms. Korean J Intern Med [Internet]. 2015 Nov 30 [cited 2018 Jul 9];30(6):771-88. Available from: http://kjim.org/journal/view.php?doi=10.3904/kjim.2015.30.6.771

4. Randolph TR. Myeloproliferative neoplasms. In: Rodak's hematology clinical applications and principles. 5th ed. St. Louis, Missouri: Saunders; 2015. p.561-90. 
5. Randolph TR. Myeloproliferative neoplasms. In: Clinical laboratory hematology. 3rd ed. New Jersey: Pearson; 2015. p. 450-78. 


\section{7}

\section{Primary Myelofibrosis (PMF)}

\section{MICHELLE TO AND VALENTIN VILLATORO}

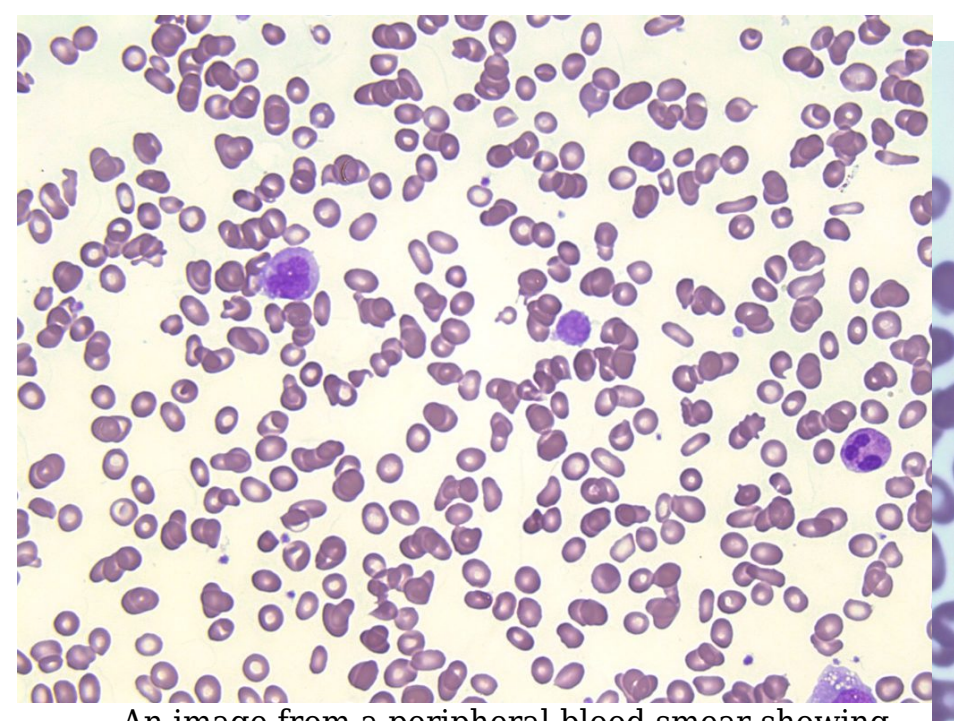

An image from a peripheral blood smear showing tears, elliptocytes, schistocytes, and a giant platelet seen in primary myelofibrosis. 50x oil immersion. From MLS Collection, University of Alberta, https://doi.org/10.7939/R3CJ88201

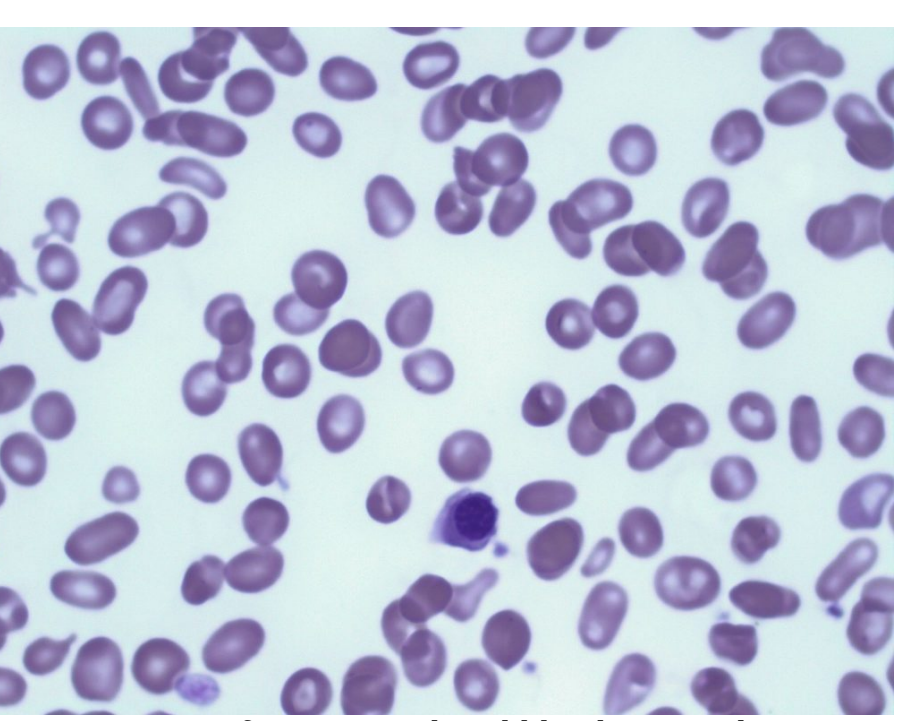

An image from a peripheral blood smear showing tears, elliptocytes, and schistocytes, and a nucleated red blood cell seen in primary myelofibrosis. 100x oil immersion. From MLS Collection, University of Alberta, https://doi.org/10.7939/R3416TF2F

Affected Cell Line: Granulocytes and Megakaryocytes in the bone marrow resulting in secondary fibroblast stimulation and fibrotic desposition in the bone marrow. ${ }^{1,2}$

Mutation: JAK 2 V617F, CALR, and MPL gene mutations. ${ }^{1,3}$

Age Group Affected: >50 years old, occurs equally between males and females. ${ }^{4}$

\section{Features:}


Primary myelofibrosis is characterized by two stages:

\section{Prefibrotic Stage}

The bone marrow is hypercellular and shows minimal reticulin and fibrosis initially, with an increase in megakaryocytes and granulocytes. ${ }^{1}$

\section{Fibrotic Stage}

Peripheral blood shows a characteristic leukoerythroblastic picture (immature granulocyte and erythrocyte precursors) with poikilocytosis, especially teardrop cells and elliptocytes. ${ }^{1}$

Bone marrows shows marked fibrosis. ${ }^{1}$ Extramedullary hematopoiesis is often seen, with cells accumulating in the spleen, liver, and other organs.

\section{Laboratory Findings for Primary Myelofibrosis: ${ }^{2,4,5}$}

\section{CBC:}

Early Stage:

RBC: Normal

WBC: Increased

PLT: Increased

Hb: Normal

Fibrotic Stage:

RBC: Decreased

WBC:Decreased

PLT: Decreased

$\mathrm{Hb}$ : Decreased

Other Tests:

PLT Function: Abnormal

\section{PBS:}

Platelets have a dysplastic morphology

(Giant, agranular)

May see micromegakaryocytes

Variable poikilocytosis

\section{Fibrotic Stage:}

Pancytopenia

Leukoerythroblastic picture

Teardrop cells

Elliptocytes

nRBCs
BM:

Often results in a dry tap

Hypercellular

Fibrosis of varying degrees (Marked fibrosis in later stages)

Megakaryocyte aggregates

Dysgranulopoiesis

Dysmegakaryopoiesis

\section{References:}

1. Swerdlow SH, Campo E, Harris NL, Jaffe ES, Pileri SA, Stein H, et al. editors. WHO Classification of Tumours of Haematopoietic and Lymphoid Tissues Volume 2. 4th ed. International Agency for Research on Cancer (IARC); 2008. 
2. Schaub CR. Chronic Myeloproliferative disorders I: chronic myelogenous leukemia. In: Clinical hematology and fundamentals of hemostasis. 5th ed. Philadelphia: F.A. Davis Company; 2009. p. 371-84.

3. Choi CW, Bang S-M, Jang S, Jung CW, Kim H-J, Kim HY, et al. Guidelines for the management of myeloproliferative neoplasms. Korean J Intern Med [Internet]. 2015 Nov 30 [cited 2018 Jul 9];30(6):771-88. Available from: http://kjim.org/journal/view.php?doi=10.3904/kjim.2015.30.6.771

4. Randolph TR. Myeloproliferative neoplasms. In: Clinical laboratory hematology. 3rd ed. New Jersey: Pearson; 2015. p. 450-78.

5. Randolph TR. Myeloproliferative neoplasms. In: Rodak's hematology clinical applications and principles. 5th ed. St. Louis, Missouri: Saunders; 2015. p.561-90. 


\section{WHITE BLOOD CELLS: \\ MYELODYSPLASTIC SYNDROMES \\ (MDS)}

XV 


\section{8 \\ Introduction to Myelodysplastic \\ Syndromes (MDS)}

MICHELLE TO AND VALENTIN VILLATORO

Myelodysplastic syndromes are a group of clonal disorders that result in cytopenias and defective cell maturation. ${ }^{1}$ Morphology of cells during maturation show abnormalities, referred to as dysplasia. ${ }^{2}$ Dysplastic features seen varies in terms of the types of dysplasia seen, and the cell lines affected. Progression toward acute leukemia is often seen later in the disease, leading to an increase in blasts seen in the bone marrow and peripheral blood.

Age Group Affected: Commonly age of diagnosis is 70 years old. ${ }^{1}$

Affected Cell Line(s): Can affect one, two, or all three hematopoietic cell lines (erythroid, myeloid, megakaryocyte). ${ }^{1}$

\section{Cause(s):}

Chromosomal abnormalities

Mutations in oncogenes and tumor suppressor genes

General Laboratory Findings for MDS: ${ }^{2}$ 
PBS:

Anemia

Anisocytosis (Dimorphic)

Poikilocytosis

Sideroblasts

Dysplastic granulocytes

Dysplastic thrombocytes

$+/$ - Increased blasts
BM:

Dysplastic hematopoietic precursors

Usually hypercellular (though hematopoiesis is ineffective)

$+/$ - Increased blasts
Other Tests:

Cytogenetic testing

FISH

Iron Studies:

Serum Iron: Normal to Increased Serum Ferritin: Normal to Increased TIBC: Decreased to Normal

\section{References:}

1. Rodak BF. Myelodysplastic syndromes. In: Rodak's hematology clinical applications and principles. 5th ed. St. Louis, Missouri: Saunders; 2015. p.591-603.

2. Lawrence LW, Taylor SA. Myelodysplastic syndromes. In: Clinical laboratory hematology. 3rd ed. New Jersey: Pearson; 2015. p. 479-99. 


\section{9}

MDS: Dyserythropoiesis,

Dysmyelopoiesis \&

Dysmegakaryopoiesis

\section{MICHELLE TO AND VALENTIN VILLATORO}

As previously discussed, MDS is a clonal disorder that results in defective cell maturation and results in dysplastic changes. The dysplasia can be seen in both the peripheral blood and in the bone marrow. Dysplasia may be seen in one or more cell lines, and the types of dysplasia seen vary. Below are descriptions that may be seen, organized by cell lineage.

\section{Dyserythropoiesis}




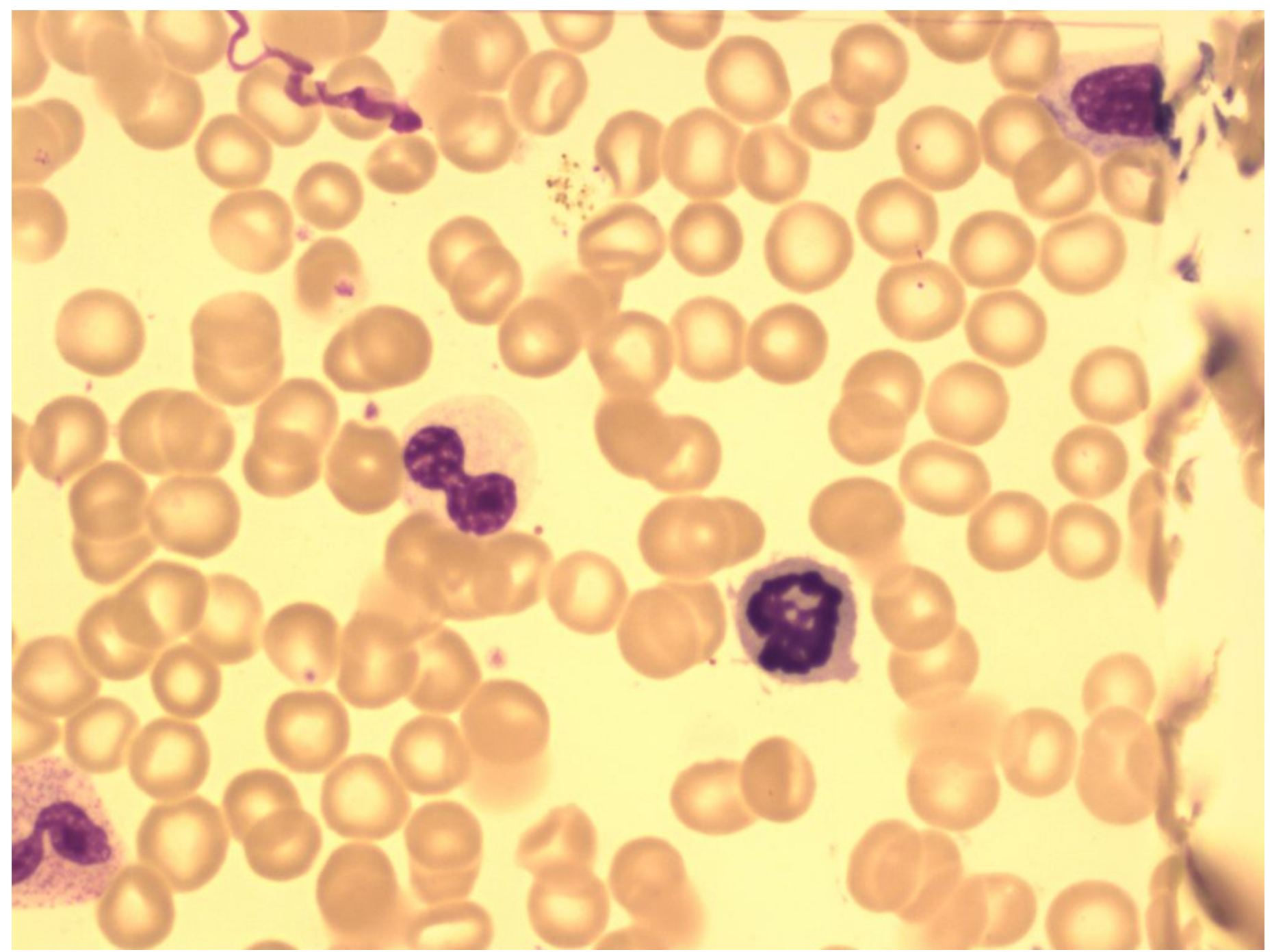

An image from a bone marrow smear showing a hypogranular, hyposegmented neutrophil (center-left) and a mitotic figure that appears to be an erythroid precursor (center-right) seen in myelodysplastic syndrome. 100x oil immersion. From MLS Collection, University of Alberta, https://doi.org/10.7939/R34M91S2D

Affected Cell line: Erythroids. ${ }^{1-3}$

Table 1. Dysplastic features found in MDS erythrocytes in the peripheral blood and bone marrow. ${ }^{1-3}$ 
PBS:

Dimorphic Population

Oval-macrocytes

Hypochromic/Microcytic RBCs (with normal iron stores)

Basophilic stippling

Howell-Jolly bodies

Siderocytes

Decreased polychromasia
BM:

Multiple Nuclei

Abnormal Nuclear shapes (budding, lobes, fragmentation, bridging)

Megaloblastoid features

Vacuolization

Ringed Sideroblasts

Abnormal staining of the cytoplasm (due to basophilic stippling and hemoglobin)

\section{Dysmyelopoiesis/Dysgranulopoiesis}

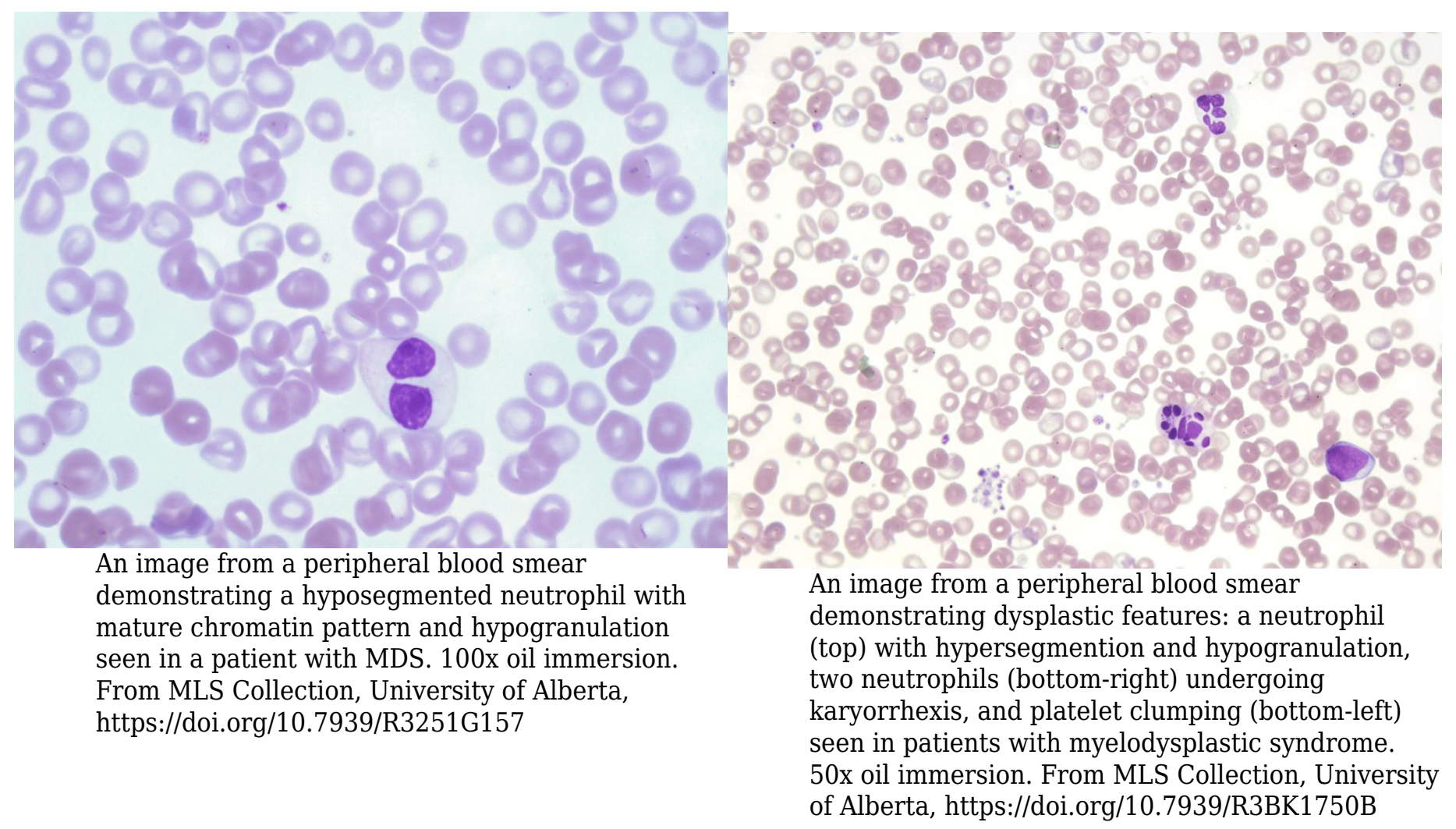




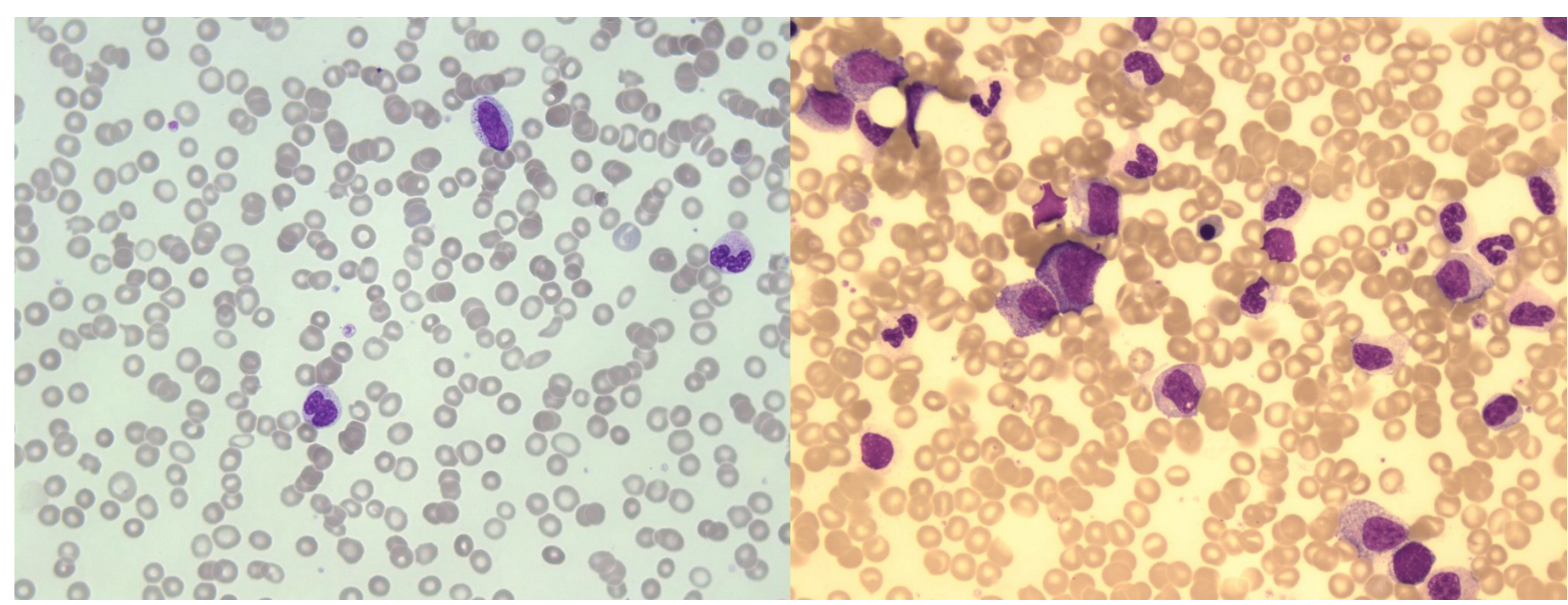

An image from a peripheral blood smear showing hyposegmented neutrophils and a myeloid precursor seen in myelodysplastic syndrome. 50x oil immersion. From MLS Collection, University of Alberta, https://doi.org/10.7939/R3KP7V654

An image from a bone marrow smear showing hypogranular neutrophils and hypogranular myeloid precursors seen in myelodysplastic syndrome. 50x oil immersion. From MLS Collection, University of Alberta,

https://doi.org/10.7939/R38C9RK5P

Affected Cell line: Granulocytes. ${ }^{1-3}$

\section{Table 2. Dysplastic features found in MDS granulocytes in the peripheral blood and bone} marrow. ${ }^{1-3}$

\section{PBS:}

Agranulation

Hypogranulation

Abnormal nuclear shapes (hypersegmentaion, hyposegmentation,

ring-shaped nuclei)

Left shift

Monocytosis

Neutropenia

Increased Blasts
BM:

Nuclear-cytoplasmic asynchrony

Abnormal cytoplasmic staining

Abnormal granulation (hypogranulation, hypergranulation)

Increased Blasts

$+/$ - Auer rods

\section{Dysmegakaryopoiesis}




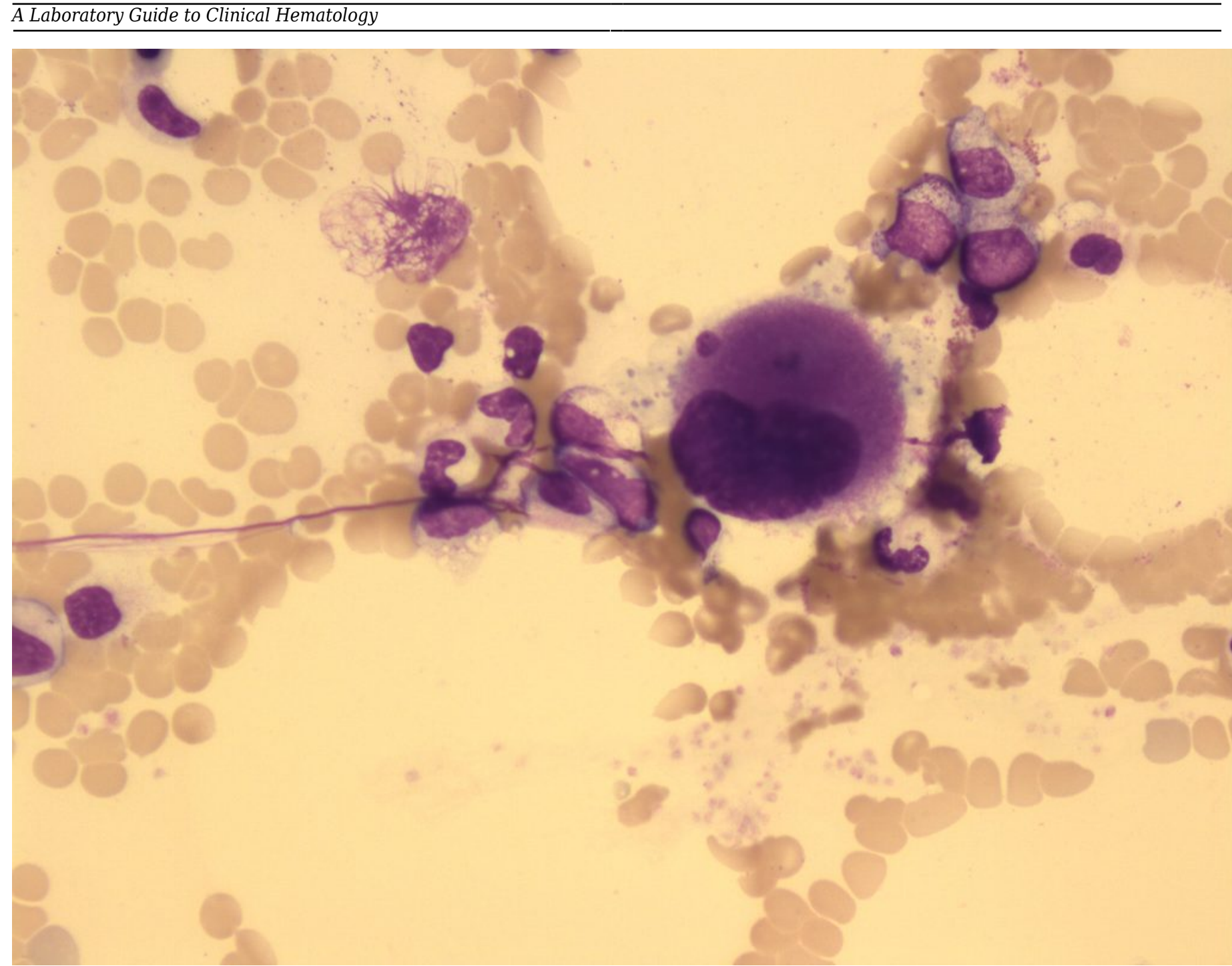

An image from a bone marrow smear showing mononuclear megakaryocyte seen in myelodysplastic syndrome. 50x oil immersion. From MLS Collection, University of Alberta, https://doi.org/10.7939/R3D21S081

Affected Cell line: Megakaryoctyes and platelets. ${ }^{1-3}$

Table 3. Dysplastic features found in MDS megakaryocytes and platelets in the peripheral blood and bone marrow. ${ }^{1-3}$ 
PBS:

Thrombocytopenia

Hypogranulation/Agranulation

Micromegakaryocytes

Giant PLTs
BM:

Magakaryocytes with multiple separated nuclei

Abnormal granulation (hypogranulation)

Large mononuclear megakaryocytes

Micromegakaryocytes

Micromegakaryoblasts

\section{References:}

1. Rodak BF. Myelodysplastic syndromes. In: Rodak's hematology clinical applications and principles. 5th ed. St. Louis, Missouri: Saunders; 2015. p.591-603.

2. Lawrence LW, Taylor SA. Myelodysplastic syndromes. In: Clinical laboratory hematology. 3rd ed. New Jersey: Pearson; 2015. p. 479-99.

3. D’Angelo G, Mollica L, Hebert J, Busque L. Myelodysplastic syndromes. In: Clinical hematology and fundamentals of hemostasis. 5th ed. Philadelphia: F.A. Davis Company; 2009. p. 412-39. 


\section{Thank You}

This is eBook will be constantly updated, edited, and reviewed as new emerging information arises. Should you have any suggestions, feedback, questions, or corrections regarding the content of this eBook, please contact Valentin (Tino) Villatoro. His contact information is listed below:

Email: valentin@ualberta.ca

Notice an issue or error? Use our Troubleshooting form to notify us:

https://docs.google.com/a/ualberta.ca/forms/d/1hT9uI8glWpQ8ljnrMeFMAkUJgl3qsEu4_HpIpjlnekY/edit ?usp=sharing

Want to give us feedback on this eBook and the resources provided? Use our Feedback form to let us know:

https://docs.google.com/a/ualberta.ca/forms/d/1dz6JhvLVk8mCi29Y3zQISeH_TMnwHQv3-ARWbQ5Vnm $\underline{\mathrm{U} / \mathrm{edit} \text { ?usp }=\text { sharing }}$ 